





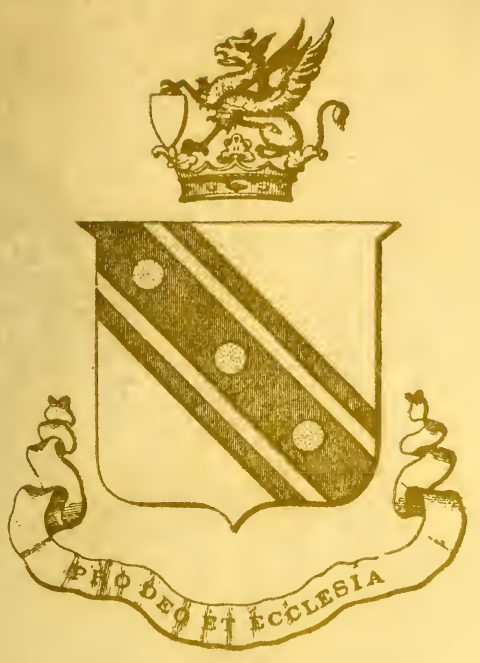

\title{
THE ART COLLECTION
}

\author{
FORMED BY THE LATE \\ HEBER R. BISHOP
}

AMERICAN ART GALLERIES

MADISON SQUARE SOUTH

NEW YORK 



ON VIEW DAY AND EVENING AT THE AMERICAN AR'T GALLERIES MADISON SQUARE SOUTH, NEW YORK

FROM FRIDAY, JANUARY 12TH, 1906 UNTIL 'THE DAY OF SALE, INCLUSIVE

THE ART COLLECTION FORMED BY THE LATE

\section{HEBER R. BISHOP}

EXECU'TORS' UNRESTRICTED

PUBLIC SALE

A'T THE AMERICAN AR'T GALLERIES

ON THE AFTERNOONS OF JANUARY 1\% $18 \mathrm{TH}, 19 \mathrm{TH}, 20 \mathrm{TH}, 22 \mathrm{ND}, 23 \mathrm{RD}, 24 \mathrm{TH}, 25 \mathrm{TH}, 26 \mathrm{TH}, 4 \mathrm{ND}$ 27TH, AND EVENINGS OF JANUARY 22ND AND 23RD

AND

AT MENDELSSOHN HALL

ON THE

EVENING OF FRIDAY, JANUARY 19TH 



\author{
CATALOGUE \\ $\mathrm{OF}$ \\ THE ART COLLECTION
}

FORMED BY THE LA'TE

\title{
HEBER R. BISHOP \\ NEW YORK
}

EDITED BY THOMAS E. KIRBY

THE ENTIRE COLLECTION TO BE SOLD AT UNRESTRICTED PUBLIC SALE BY ORDER OF THE EXECUTORS, BEGINNING JANUARY 17TH, 1906 UNDER THE MANAGEMENT OF

\section{THE AMERICAN AR'T ASSOCIATION NEW YORK




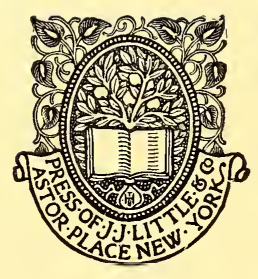




\title{
ORDER OF SALE
}

\author{
EVENING SESSIONS
}

ON FRIDAY EVENING, JANUARY 19тн, 1906

AT MENDELSSOHN HALL, Fortieth Street, East of Broadway, beginning promptly at 8.15 o'clock. THE VALUABLE PAINTINGS, Catalogue Nos. 1 to 86 inclusive.

\section{MONDAY EVENING, JANUARY 22ND}

AT THE AMERICAN ART GiLLERIES, Madison Square South, promptly at 8 o'clock. ANTIQUE JAPANESE AND CHINESE KAKEMONOS AND PANELS. Catalogue Nos. 2725 to 2879 inclusive.

\section{TUESDAY EVENING, JANUARY 23RD}

AT THE AMERICAN ART GALLERIES, Madison Square South, promptly at 8 o'clock. ANTIQUE JAPANESE AND CHINESE BOOKS AND EUROPEAN ETCHINGS AND ENGRAVINGS. Catalogue Nos. 2880 to 3007 inclusive.

\section{AFTERNOON SESSIONS}

\section{WEDNESDAY AFTERNOON, JANUARY 1\%}

AT THE AMERICAN ART GALLERIES, promptly at 2.30 o'clock. JAPANESE SWORD GUARDS (TSUBA), KNIFE HANDLES, SWORD MOUNTS AND CABINET COLLECTIONS OF EXTRAORDINARY EXAMPLES OF METAL WORK. Catalogue Nos. 1 to 274 inclusive.

\section{THURSDAY AFTERNOON, JANUARY 18TH}

AT THE AMERICAN ART GALLERIES, at 2.30 o'clock. IMPORTANT JAPANESE AND EUROPEAN IVORY CARVINGS, IVORY AND WOOD NETSUKES. Catalogue Nos. 275 to 550 inclusive. 


\section{FRIDAY AFTERNOON, JANUARY 19тн}

AT THE AMERICAN ART GALLERIES, beginning promptly at 2.30 o'clock. CHINESE JADE, GLASS, ANTIQUE JAPANESE TOBACCO POUCHES, PIPES AND PIPE CASES AND MISCELLANEOUS CABINET OBJECTS. Catalogue Nos. 551 to 831 inclusive.

\section{SATURDAY AFTERNOON, JANUARY 20TH}

AT THE AMERICAN ART GALLERIES, Madison Square South, beginning promptly at 2.30 o'clock. BEAUTIFUL ANTIQUE CHINESE PORCELAINS, DECORATED, BLUE AND WHITE SOFT PASTE AND

CELADON SPECIMENS. Catalogue Nos. 832 to 1111 inclusive.

\section{MONDAY AFTERNOON, JANUARY 22ND}

AT THE AMERICAN ART GALLERIES, beginning promptly at 2.30 o'clock. SUPERB JAPANESE LACQUERS AND INROS. Catalogue Nos. 1112 to 1408 inclusive.

\section{TUESDAY AFTERNOON, JANUARY 23RD}

AT THE AMERICAN ART GALLERIES, beginning promptly at 2.30 o'clock. BOWLS, ANTIQUE SUPERB JAPANESE LACQUERS AND INROS. Catalogue Nos. 1409 to 1664 inclusive.

\section{WEDNESDAY AF'TERNOON, JANUARY 24TH}

AT THE AMERICAN ART GALLERIES, beginning promptly at 2.30 o'clock. VERY FINE ANTIQUE CHINESE AND JAPANESE BRONZES. Catalogue Nos. 1665 to 1935 inclusive.

\section{THURSDAY AFTERNOON, JANUARY 25TH}

AT THE AMERICAN ART GALLERIES, beginning promptly at 2.30 o'clock. REMARKABLE ANTIQUE CHINESE AND JAPANESE BRONZES and ARTICULATED IRON WORK, ANTIQUE CLOISONNE ENAMELS AND CHAMPLEVE. Catalogue Nos. 1936 to 2195 inclusive.

\section{FRIDAY AFTERNOON, JANUARY 26TH}

AT THE AMERICAN ART GALLERIES, beginning promptly at 2.30 o'clock. ANTIQUE JAPANESE AND EUROPEAN ARMS AND ARMOR. Catalogue Nos. 2196 to 2490 inclusive.

\section{SATURDAY AFTERNOON, JANUARY $2 \%$ TH}

AT THE AMERICAN ART GALLERIES, beginning promptly at 2.30 o'clock. SUMPTUOUS ANTIQUE CHINESE AND JAPANESE COSTUMES AND PALACE HANGINGS, ANTIQUE CHINESE CARPETS, ART FURNITURE AND MISCELLANEOUS OBJECT'S. Catalogue Nos. 2492 to 2724 inclusive. 


\section{CONDITIONS OF SALE}

1. The highest Bidder to be the Buyer, and if any dispute arise between two or more Bidders, the Lot so in dispute shall be immediately put up again and re-sold.

2. The Auctioneer reserves the right to reject any bid which is merely a nominal or fractional advance, and therefore, in his judgment, likely to affect the Sale injuriously.

3. The Purchasers to give their names and addresses, and to pay down a cash deposit, or the whole of the Purchase-money, if required, in default of which the Lot or Lots so purchased to be immediately put up again and re-sold.

4. The Lots to be taken away at the Buyer's Expense and Risk: within twenty-four hours from the conclusion of the Sale, and the remainder of the Purchase-money to be absolutely paid, or otherwise settled for to the satisfaction of the Auctioneer, on or before delivery; in default of which the undersigned will not hold themselves responsible if the lots be lost, stolen, damaged, or destroyed, but they will be left at the sole risk of the Purchaser.

5. While the undersigned will not hold themselves responsible for the correctness of the description, genuineness, or authenticity of, or any fault or defect in, any Lot, and make no Warranty whatever, they will, upon receiving previous to date of Sale trustworthy expert opinion in writing that any Painting or other Work of Art is not what it is represented to be, use every effort on their part to furnish proof to the contrary; failing in which, the object or objects in question will be sold subject to the declaration of the aforesaid expert, he being liable to the Owner or Owners thereof, for damage or injury occasioned thereby.

6. To prevent inaccuracy in delivery, and inconvenience in the settlement of the Purchases, no Lot can, on any account, be removed during the Sale.

7. Upon failure to comply with the above conditions, the money deposited in part payment shall be forfeited; all Lots uncleared within one day from conclusion of Sale shall be re-sold by public or private sale, without further notice, and the deficiency (if any) attending such re-sale shall be made good by the defaulter at this Sale, together with all charges attending the same. This Condition is without prejudice to the right of the Auctioneer to enforce the contract made at this Sale, without such re-sale, if he thinks fit.

8. The undersigned are in no manner connected with the business of the cartage or packing and shipping of purchases, and although they will afford to purchasers every facility for employing careful carriers and packers, they will not hold themselves responsible for the acts and charges of the parties engaged for such services.

The AMERICAN ART ASSOCIATION, Managers

THOMAS E. KIRBY, Auctioneer. 



\section{ARTISTS REPRESENTED AND THEIR WORKS}

ADAM-KUNZ, L.,

Still Life

BAUR, Professor Albert,

A Roman Banquet

64

BECKER, Karl Ludwig Friedrich, Sappho

BECKER, Q.,

Old Woman's Head

BENLLIURE, José,

The Swashbuckler

BIERSTADT, Albert,

Sierra Nevada

BISSCHOP, C.

Grace before Meat

BLAKE, BenJamin,

Game

Game

Boughton, George Henry, R.A.,

A Bit of Blue and White

BoUguereaU, Willian Adolphe,

The Pet Bird

BRETON, Émile Adélard, 
BROŽIK, VACSLAV voN,

The Uncle's Visit

BRÜCK-LAJOS, LouIs,

The Young Savoyard

CAFFERTY, James H., N.A.,

A Roundhead

CASANOVA y ESTORACH, Antonio,

The Connoisseur

CHARLEMONT, Édouard,

Out for a Walk

ChURCH, Frederick E., N.A.,

Morning in the Tropics

68

Clays, Paul Jean,

On the Zuyder Zee

COROT, Jean Baptiste Camir.le,

Ville d'Avray-Morning

DEFrEGGER, Franz von,

A Bavarian Pedagogue

A Bavarian Peasant

DEGAS, Hilaire Germain Edgard,

The Dancers

DE NEUVille, Alphonse M.,

A Soldier

A Corporal of Infantry

A French Soldier

The Sergeant Major

The Attack

Officers Reconnoitring

DE PEnNe, Charles Olivier,

A Group of Dogs

Black and Tan Hounds 
DETAILLE, J. B. Édouard,

Diaz, Narcisse Virgiee,

Flora,

DOMINGO, JosÉ,

The Reconnoissance

DUPRAY, Henri Louis,

Grand Manœuvres

22

An Accident at the Manœuvres

DUPRÉ, JULES,

Landscape

GAUBAULT, A.,

Plans

56

Despatches

GÉLIBERT, Jules Bertrand,

At the Rendezvous

GIFFORD, SANFord R., N.A.,

Italian Landscape

GRÜTZNER, EduARD,

Trio in the Monastery

HAGELSTEIN, PaUL,

The Little Flower Girl

HAMMAN, Édouard,

Hesitation

HEILBUTH, Ferdinand,

Contemplation

HERZoG, Hermann, 
ISRAËLS, JoseF,

The Rising Tide

JOHNSTONE, H. J.,

On the River Goulborn, Victoria, Australia

A Backwater of the River Murray, South Australia

A Backwater of the River Murray, South Australia

KNAUS, Ludwig,

Child's Head

Girl's Head

The Chimney Sweep

KNIGHT, Daniel Ridgway,

Haying Time-Scene near Poissy : the country seat of Meissonier

KOWALSKI, Alfred von Wierusz,

On the Road to the Hunt

LAGYE, Victor,

The Historiographer

LAMBINET, ÉmILE,

Landscape

LEYENDECKER, PAUl,

An Old Roman

MAX, Gabriel,

Raising of Jairus' Daughter

MERLE, Hugues,

Mother and Child

The First Lesson

Micas, Mlle. Jeanne,

Sheep in the Highlands 
MUNKÁCSY, MiHáLy,

PETERSON, John E. C.,

United States Frigate Monongahela

PILOTY, Carl Theodor von,

A Lady Reading

RIBot, A. Théodule,

The Gunmaker's Apprentice

RICHARDS, William Trost,

A Bit of Jersey Coast

RICHET, L'ÉoN,

Near Fontainebleau

Landscape

At the Well

RICO, Martin,

Cap Martin, Mentone

ROUSSEAU, Philippe,

The Heron and the Snail 73

The Cock and the Pearl $\% 4$

ROYBET, Ferdinand,

The Standard Bearer $\quad 67$

SCHREYER, Adolf,

Bulgarian Smugglers

TROYON, Constant,

Sheep at Pasture

Landscape and Cattle

UNKNOWN,

Dogss and Game

vernet, Antoine Charles Horace (called Carle),

A Roman Triumph 
VERSCHUUR, C. WALTER,

Stable Interior

VIBERT, Jehan Georges,

The Valet de Chambre

VOLTZ, Friedrich,

Harvest Time

WAHLbERG, Alfred,

Moonlight on the Fiord $\quad 54$

WALKER, J. A.,

The Outposts $\quad 36$

WEEKS, Edwin Lord,

A Halt at the Fountain 


\title{
CATALOGUE
}

\author{
SALE A'T MENDELSSOHN HALL \\ FRIDAY EVENING, JANUARY 19 тн, 1906 \\ BEGINNING PROMPTLY AT 8.15 o'CLOCK
}

No. 1

BENJAMIN BLAKE

ENGLISH

$-1830$

\section{GAME}

A BRACE of ducks, a string of onions and a large hare hang from a beam in a larder or kitchen just above a heavy wooden table, on which stands an earthen jug and a drinking cup. The group is in a strong light, relieved against the sober gray tones of the interior. On the left is a latticed window showing foliage through the leaded glass.

Signed at the lower right, B. B ВAKE, 1829.

Height, 8 inches; length, 10 inches. 
No. 2

\section{BENJAMIN BLAKE \\ ENGLISH \\ $-1830$}

\section{GAME}

A LARGE gray heron, a brace of quail and a wood duck are arranged together with two bottles on a carved oak table. In the background under a stone arch is a niche with flasks and various other objects.

Signed at the lower right, B. BLAKE, 1829.

Height, $71 / 2$ inches; length, 10 inches.

No. 3

SANFORD R. GIFFORD, N.A. AMERICAN

$1823-1880$

\section{ITALIAN LANDSCAPE}

This is a wide view over the Roman Campagna, with a lofty, rugged elevation on the left crowned with the towers and roofs of a large town. On the right in the immediate foreground is a sunlit path, winding between two rows of trees, with a group of peasant women in gay costumes. The sun, near the horizon, shines full upon the landscape, the strong light reflected in a sinuous stream in the foreground and veiling the distance in a soft, warm haze.

Signed at the lower right, S. R. GIFFond, ' 69.

Height, 7 inches; length, 13 inches. 


\section{No. 4 \\ ÉDOUARD CHARLEMON'T \\ FRENCH}

1848

\section{OUT FOR A WALK}

A Dutcr gentleman dressed in full black costume of the early seventeenth century, with short ample cloak and broad-brimmed hat, black silk breeches and stockings, is just about to leave his residence for his daily promenade. Behind him is a red-painted wooden staircase, winding up to the left, and on the right the panels of a partly opened door.

Signed at the lower right, E. Chardemont, 1881.

Height, 71/2 inches; width, 41/2 inches.

No. 5

JOSÉ DOMINGO

SPANISH

1843

\section{THE RECONNOISSANCE}

A LitrLe incident of one of the Napoleonic campaigns. A general mounted on a sturdy white horse, and followed by two officers of his staff, is riding over a rough rolling country. Beyond the group is a line of grass-covered hills, with a suggestion here and there of a battle in progress. The sky is covered with white clouds, mingling with the smoke from the guns.

Signed at the lower right, Donungo, Paris, 1880.

Height, 41/2 inches; length, 10 inches.

From Durand-Ruel, Paris, 1881. 
No. 6

\section{JEHAN GEORGES VIBERT \\ FRENCH \\ $1840-1904$}

\section{THE VALET DE CHAMBRE}

A seventeenth-century house-servant in a rich livery of velvet, with a leather jerkin and broad ruff, stands at the foot of a staircase holding an earthen ewer and basin. On the right is a pilaster with painted decorations, and on the left a group of still life arranged on a tabouret under a striped curtain.

Signed at the lower right, J. G. VIBERT, 1870.

Height, 5 inches; width, $3 \frac{1}{2}$ inches.

No. 7

\section{HUGUES MERLE}

FRENCH

$1823-1881$

\section{MOTHER AND CHILD}

A young mother, suckling an infant a few months old, is seated facing the spectator. She clasps, in both arms, the naked child, and gazes at it with a rapt expression of motherly love. Her white chemise has partly fallen from her shoulders, disclosing a shapely neck and bust. The lower part of her figure is draped in a blue petticoat and yellow overskirt. The little group is relieved against a war'm gray background.

Signed at the left, HMrru, 1865.

Height, 91/2 inches; width, 71/2 inches. 
No. 8

\section{CHARLES OLIVIER DE PENNE \\ FRENCH \\ $1831-1897$}

\section{A GROUP OF DOGS}

Four sporting dogs, three of them spotted black, white and gray, are grouped together on a bit of rough ground in an open landscape, all intent on some interesting action or watching an object near at hand. The group is in full sunlight and in strong contrast of light and shade. In the distance on the right is a line of arid hills which form the horizon, and on the left behind the dogs is a straggling clump of bushes.

Signed at the lower right, DE PENNe.

Height, 9 inches; length, 13 inches.

From M. Bernheim, Paris, 1881.

No. 9

\section{JOSÉ BENLLIURE SPANISH}

1858 -

\section{THE SWASHBUCKLER}

A roystering man-at-arms in a seventeenth-century costume, with buff coat, riding boots and broad gray hat, stands with legs wide apart, as if he might possibly have dined too well, holding a pipe in his left hand and supporting his right hand on his hip. A blue silk sash is knotted around his chest, and a bandolier hangs under the right arm. Behind him is the arched entrance to a courtyard, and, on the right, a carved stone doorway with an iron-studded door.

Signed at the lower left, J. BENLliure.

Height, 8 inches; width, 5 inches.

From Martin Colnaghi, London, 1881. 
No. 10

\section{HUGUES MERLE}

\section{FRENCH}

$1823-1881$

\section{THE FIRST LESSON}

A young girl, in peasant dress of blue bodice over a white chemise and wine-colored petticoat, holds in her lap her little baby brother, to whom she is endeavoring to teach his letters from a crumpled book. The child evidently resents serious study, and is on the point of bursting into tears. In the background is a window opening, with a pot of red carnations.

Signed at the lower right, Hugues Merce.

Height, 91/2 inches; width, 71/2 inches.

No. 11

\section{LUDWIG KNAUS}

GERMAN

$1829-$

\section{CHILD'S HEAD}

A HALF life-size study of the head of a child of five or six years of age. The face is framed by a mass of curly brown hair. Around the neck is a full linen ruffle, contrasting with the tones of the flesh and the green of a silk frock. The head is seen in three-quarters view, slightly inclined to the left, and the brown eyes look straight out of the picture. The background is a simple tone of warm brown.

signed at the upper right, L. KNaUs.

Height, 101/2 inches; width, 8 inches.

From Honrath \& Von Baerle, Berlin, 1881. 
No. 12

\section{ANTONIO CASANOVA Y ESTORACH SPANISH}

Contemporary

\section{THE CONNOISSEUR}

Av old Capuchin monk, in ragged vestments, is seated on a sherry cask in a wine cellar in a very jolly frame of mind. He holds a quaint decanter with a long spout, from which he skilfully directs a thin stream of wine into his open mouth. Engaged in this pleasant diversion he has quite forgotten that the open spigot is filling to overflowing a second decanter beneath the wine cask.

Signed at the lower left, Anto Casanova y Estorach, Paris, 1881.

Height, 101/2 inches; width, 81/2 inches.

From M. KNoeduer \& Co., New York, 1881.

No. 13

\section{HILAIRE GERMAIN EDGARD DEGAS}

\section{FRENCH}

$1834-$

\section{THE DANCERS}

\section{Pastel}

THREE ballet girls, in richly colored dresses, and with their hair hanging down their backs, stand in the wings of a theatre preparatory to making their entrance. The background represents the twisted forms of trees and mountain scenery.

Signed at the lower left, Degas.

Height, 11 inches; width, 10 inches.

From Arnold \& Tripp, Paris, 1881. 
No. 14

\section{LUDWIG KNAUS}

\section{GERMAN}

$1829-$

\section{GIRL'S HEAD}

THIs is a study of a vivacious young girl in the costume of the eighteenth century. The head is in three-quarters view, and turned over the left shoulder, which is seen in profile. She wears a striped brocade Watteau gown, with a narrow ruff around the throat and a wine-colored ribbon in her wavy brown hair. 'The background is a graded tone of gray.

Signed at the lower left, L. Kvaus, 1881.

Height, 11 inches; width, 9 inches.

From S. P. Avery, Now York, 1881.

No. 15

\section{ALPHONSE M. DE NEUVILLE} FRENCH

$1836-1885$

\section{A SOLDIER}

A sTUDY of a young infantryman leaning on his rifle and holding a cigarette in his left hand. He is seen in threequarters view, his back turned toward the spectator, displaying his miscellaneous burden of a blanket roll, cooking kettle, water bottle, haversack and ammunition pouch.

Signed at the lower left, A. DE Neuvilue, 1878.

Height, 111/2 inches; width, 61/2 inches.

From M. Bernifein, Paris, 1881. 
No. 16

\section{LÉON RICHET}

\section{FRENCH}

Contemporary

\section{NEAR FONTAINEBLEAU}

A group of trees in the middle distance, surrounding a redroofed cottage, is the chief feature of the composition. On the left is seen in the distance a village and a line of low hills beyond. A country road winds out of the flat meadow in the foreground, which is entirely in shadow. A strong gleam of sunlight touches the cottage, the meadow and a pool in the middle distance, near which is seated the figure of a peasant woman.

Signed at the lower left, L. Richet, 'rg.

Height, 121/2 inches; length, 18 inches.

From M. Knoedier \& Co., New York, 1881.

No. 17

CARL THEODOR VON PILOTY

GERMAN

$1826-1886$

\section{A LADY READING}

A Full-Length figure of a young patrician lady, in sixteenth-century costume of white, embroidered in gold. She has sought the seclusion of a shady nook in the garden to read a favorite book of poems, which she holds in her right hand. Her long fair hair, brushed back over the ears, falls loosely over her shoulders, and in her extended left hand she holds a crimson carnation.

Signed at the lower left, C. Piцоту.

Height, 111/2 inches; width, 61/2 inches. 
No. 18

\section{ALPHONSE M. DE NEUVILLE FRENCH \\ $1836-1885$}

\section{A CORPORAL OF INFANTRY}

A FULL-LENGTH figure of a hirsute soldier, who, judging from his two medals and the service stripes on his arm, has experienced at least two campaigns. He is dressed in a shako with red, white and blue pompon, a blue doublebreasted greatcoat with red epaulettes, loose red trousers and linen gaiters. He carries his chassepot at right shoulder shift, and stands at ease, resting his weight on his right leg.

Signed at the lower left, A. DE Neuville, 1877.

Height, 12 inches; width, 8 inches.

From Arnold \& Tripp, Paris, 1881.

No. 19

\section{JEAN BAPTISTE ÉDOUARD DETAILLE FRENCH}

$1848-$

\section{THE GENERAL GUIDE}

A RED-BEARDED sapper in dark blue and black uniform, with clumsy knapsack piled high with kettle and tent poles, stands in profile, holding his musket upside down in the attitude of present arms. He is evidently acting as guide for the manœuvres of a large detachment of infantry which is seen approaching from a distance.

signed at the lower left, E. Detaille, 1875.

Height, 101/2 inches; width, 51/2 inches.

From M. Knoeduer \& Co., New York, 1881. 


\title{
PAUL LEYENDECKER \\ GERMAN
}

Contemporary

\section{AN OLD ROMAN}

A patrician gentleman of ancient Romie, dressed in a rich tunic of soft gray material and an ample blue toga with colored border, stands in an attitude of contemplation on the Street of Tombs, apparently in mournful meditation suggested by a funereal urn standing on a tomb near by. In the distance are various mausoleums under a rank of tall cypresses, and the figure of a mourning woman in purple mantle is seen leaning. on a marble sarcophagus, on which she has placed an earthen jar with the ashes of the one she mourns. The sky, against which the figure of the man is in strong relief, is covered with a luminous haze which casts shadows towards the foreground.

Signed at the lower left, Paul Leyendeckei, 1879.

Height, 131/2 inches; width, 10 inches.

\author{
No. 21. \\ JAMES H. CAFFERTY, N.A. \\ AMERICAN \\ $1819-1869$
}

\section{A ROUNDHEAD}

One of Cromwell's devout followers is seated, apparently in a church, with head uncovered, holding a Bible in both hands, which he is engaged in reading with close attention. He wears a leather-colored jerkin and a polished steel breastplate. His gray hair is closely cut, and his mustache and beard are trimmed à la Van Dyke.

Signed at the lower right, J-AFFERTY, 1868.

Height, 12 inches; width, 91/2 inches. 


\section{HENRI LOUIS DUPRAY}

\section{FRENCH}

1841 -

\section{GRAND MANEUVRES}

THE commanding general of the French army, accompanied by his staff and the various military attachés from other countries, is standing in an open field by a country roadside, conversing with the officers. On the right an aide gallops up with a report on the movements of the troops. On the left a few persons are assembled in the roadway, and in the distance, among the trees and wooded hills, are seen here and there puffs of smoke, showing that a mock battle is in progress. The sky is nearly covered with soft gray clouds.

Signed at the lower left, H. Dupray, 1881.

Height, 12 inches; length, 18 inches.

From Arnold \& Tripp, Paris, 1881.

No. 23

\section{WALTER VERSCHUUR}

DUTCH

$1812-1874$

\section{S'TABLE IN'TERIOR}

A DrIver has brought in a pair of horses for rest and fodder. One of them, a sturdy black animal, quietly stands at the rack, but the other one, white with black legs, tail and mane, has not lost its high spirits, and is rearing and prancing in spite of the efforts of the driver. On the right is a boy with a donkey. A f'ew hens seek their food here and there on the stable floor, and on the upper left is a window opening in the wall, through which is seen a small area of sunlit sky and branches of trees.

signed at the lower right, C. W. Verschund, Ft.

Height, 131/2 inches; length, 181/2 inches. 
No. 24

\section{ALPHONSE M. DE NEUVILLE FRENCH \\ $1836-1885$}

\section{A FRENCH SOLDIER}

A Full-Length study of a French soldier standing in full face, holding his musket with its long sabre bayonet in the crook of his left arm while he is engaged in lighting his short clay pipe. He is dressed in a loose blue greatcoat with red epaulettes, full red trousers, linen gaiters, and wears his somewhat battered kepi jauntily on the back of his head. On the ground beside him is his knapsack and his haversack partly open, showing a cut loaf of coarse brown bread.

Signed at the lower left, A. DE Neuville, 1876.

Height, 12 inches; width, 81/2 inches.

From M. Bernhein, Paris, 1881.

No. 25

JEAN BAPTISTE EDOUARD DETAILLE FRENCH

$1848-$

\section{CAMP SCENE}

THIs illustrates a little instance of camp life often seen in any army in the field. A camp barber is engaged in removing the stubble from the chin of a young subaltern, while his companion, half seated on a military chest close by, enlivens the tedium of the operation by his conversation. In the foreground are various metal utensils and a cartridge box. In the distance is a mass of men engaged in various occupations of camp life.

Signed at the lower left, Énound Detaille, 8bre, 1876.

Height, 131/2 inches; width, 101/2 inches.

From M. Knoedter \& Co., New York, 1881. 
No. 26

\section{LUDWIG KNAUS}

\section{GERMAN}

$1829-$

\section{THE CHIMNEY SWEEP}

A young chimney sweep, evidently elated at having finished a difficult job, is hurrying along the street bearing the various implements of his calling, brushes, rods, rough branches and the like. His head is swathed with black cloths, and his ragged costume is, naturally, the color of soot. The background is a rough plaster wall, and on the left is an overturned basket filled with straw and chaff.

Signed at the lower right, L. KNAUs, 1880.

Height, 161/2 inches; width, 12 inches.

From M. Knoedler \& Co., New York, 1882.

No. 27

CHARLES OLIVIER DE PENNE FRENCH

$1831-1897$

\section{BLACK AND 'TAN HOUNDS}

In the foreground is a group of four bloodhounds, three standing up and one lying down. In the full sunlight behind them is a group of trees and bushes with dense foliage, growing out of a low bank covered with weeds and flowers, and on the right beyond, in the distance, is a sunlit meadow bounded by irregular clusters of trees. 
No. 28

JULES DUPRE

FRENCH

1812-1889

\section{I.ANDSCAPE}

$O_{N}$ the left is a group of stately trees rising out of the sedgy low shore of a large pool of water, which extends across the foreground to the right. $\mathbf{A}$ few cattle are drinking in the middle distance, and beyond them is a level sunlit meadow with a hillside and clumps of trees beyond. The sky is filled with turbulent rolling clouds, strongly illuminated by sunlight.

Signed at the lower left, Jules Dupré.

From Arnold \& Tripp, Paris, 1881.

Height, 13 inches; length, 191/2 inches.

No. 29

\section{HENRI LOUIS DUPRAY \\ FRENCH}

$1841-$

\section{AN ACCIDEN'T AT THE MANGUVRES}

Is the foreground is a group of officers and cavalrymen halted for a moment on account of a loose shoe on the hind foot of one of the horses. The farrier and an orderly are engaged in this operation, having deposited their helmets and accoutrements on the grass, and one of them holds the horse's foot in his hand while the other stands ready to fasten the nails. On the left of the group is a stream bordered with pollard willows, and on the right, extending even to the extreme distance where all forms are lost in the summer haze, are large masses of cavalrymen apparently executing field manœuvres. The sky is partly covered with cumuli.

Signed at the lower left, H. Dupray, 1881.

From Arnold \& Tripp, Paris, 1881.

Height, 121/2 inches; length, 18 inches. 
No. 30

\section{CONSTANT TROYON}

FRENCH

1810-1865

\section{SHEEP A'T PASTURE}

In the foreground is a ewe and a half-grown lamb standing in full sunlight in a pasture. Beyond, in the middle distance, are seen other sheep resting in the pasture.

Signed at the lower left, C. Troyon.

Height, 131/2 inches; length, 18 inches.

From M. Knoeduen \& Co., New York, 1882.

No. 31

FRANZ VON DEFREGGER

GERMAN

$1835-$

\section{A BAVARIAN PEDAGOGUE}

A LIFE-SIze study of a Bavarian type of pedagogue. The face is in three-quarters view, the eyes wide open and turned to the left. He wears a black silk smoking cap and high stock, and holds in the corner of his mouth the ornamented stem of a long pipe. The face, with the exception of a gray mustache, is clean shaven, and from beneath the closely fitting cap are straggling locks of gray hair.

Signed at the upper left, F. DEFREGGER, '81.

Height, 16 inches; width, 13 inches. 
No. 32

\section{JOSEF ISRA ËLS}

\section{DUTCH}

1824

\section{THE RISING TIDE}

A young peasant boy, carrying his little sister pick-aback, is wading in the shallow water along a flat beach; his trousers are rolled up high on his thighs, and the water reaches almost to his knees. The light falls strongly upon the figures from the zenith, diffused somewhat by thin clouds which cover the sky, and the shadows are full of warm reflections. Beyond the group is seen a wide expanse of the North Sea, with a suggestion of lazily tumbling waves, and in the far distance on the left is a single fishingboat, half lost in the summer mist which hangs over the water.

Signed at the lower left, JoseF IsRaẼs.

Height, 161/2 inches; width, 111/2 inches.

From M. KNoedler \& Co., New York, 1882.

\section{No. 33}

\section{Q. BECKER}

\section{GERMAN}

Contemporary

\section{OLD WOMAN'S HEAD}

A study, nearly life-size, of an old woman's head, in threequarters view to the left. The face is framed by the soft fur trimming of a black cap and a green mantle, which is thrown around her shoulders. She has an earring in the lobe of her ear, and wears a tightly buttoned black jacket, with a standing white collar.

signed at the middle right, (BEckER.

Height, 15 inches; width, 111/2 inches.

From S. P. AvenY, New York, 1882. 


\section{NARCISSE VIRGILE DIAZ DE LA PEÑA} FRENCH

FLORA

$1807-1876$

The goddess, holding in her left arm a bunch of wild flowers and in her raised right hand a delicate butterfly, is walking over a flower-strewn meadow in the soft glow of the afternoon light. Her loosely girdled tunic half falls from her shoulders and is fastened high upon the right thigh by a golden brooch. A scarf of a delicate blue is thrown around her arms and shoulders, and, with the folds of her tunic, lightly flutters as she walks.

Signed at the lower right, N. Draz, '64.

Height, 171/2 inches; width, 9 inches.

From M. Knoedler \& Co., New York, 1882.

No. 35

\section{MLLE. JEANNE MICAS \\ FRENCH}

Contemporary

\section{SHEEP IN THE HIGHLANDS}

ON a high grassy plateau, where here and there flat ledges of rock appear among the verdure, a flock of black and white sheep, with half-grown lambs, is drowsily resting in the sunlight. In the middle distance the plateau abruptly terminates in a horizontal line, and beyond is seen a rank of distant hills, with a sky nearly covered by gray clouds.

Signed at the lower left, Jeande Micas, 1880.

Height, 19 inches; length, 26 inches.

From M. KNoEdien \& Co., New York, 1882. 


\section{J. A. WALKER \\ FRENCH}

Contemporary

\section{THE OUTPOSTS}

Two videttes are stationed at the extreme edge of a wood, where they have tethered their two horses to a stake. Both soldiers are dismounted, and one is seated on a low bank, near a small fire, in the immediate foreground, a picture of patient misery. Beyond the horses stands the second soldier, attentively watching the murky distance. The ground is covered with snow, and the cloudy sky threatens a snowstorm.

Signed at the lower left, J. A. WAIKER.

Height, 19 inches; length, 251/2 inches.

From M. KNoedler \& Co., New York, 1881.

No. 37

JEAN BAP'TISTE CAMILLE COROT FRENCH

$1796-1874$

\section{VILLE D'AVRAY-MORNING}

ON the left, growing from the low bank of a broad sheet of water, is a large clump of willows and birches, and nearby a man is poling his skiff into deep water. In the distance is seen a level tract of country, with here and there houses and trees which form the low horizon. The broad expanse of sky is covered with soft thin clouds, diffusing the strong sunlight over the whole landscape.

Signed at the lower left, CоRoт.

Height, 161/2 inches; length, 201/2 inches.

From the John Wolfe Collection, New York, April 6, 1882. 


\section{ALPHONSE M. DE NEUVILLE FRENCH}

$1836-1885$

\section{THE SERGEANT MAJOR}

A DETACHMEnT of infantry has halted on a turn in a rough road near low hills, apparently waiting for orders. In the foreground stands a sturdy young sergeant major, leaning on a stick, and nervously playing with the tassel of his sword hilt. Beyond, and along the roadside, the men lounge and sit, and two officers on horseback talk earnestly of the situation. In the distance is a row of low hills covered with cultivated fields, and above a soft-toned sky suggesting early autumn.

Signed at the lower right, A. DE NeuviLle, 1882.

Height, 20 inches; width, 16 inches.

From M. Kroedlen \& Co., New York, 1882.

No. 39

\section{ÉDOUARD HAMMAN}

BELGIAN

$1819-1888$

\section{HESITATION}

A young lady in early eighteenth-century costume of blue shot silk bodice and overskirt, pale satin petticoat and full loose sleeves, and a short black silk cape with hood over her shoulders, stands with her hand on the knob of a door, hesitating whether she shall enter or not. The figure is relieved against a tapestry background.

signed at the lower right, ED. Hamman.

Height, 20 inches; width, 12 inches. 
No. 40

\section{CONSTAN'T TROYON}

FRENCH

$1810-1865$

\section{LANDSCAPE AND CATTLE}

THis is a view across a broad, shallow stream in a pleasant farming country. On either side of the foreground are clumps of bushes growing on steep sandy banks, and between them is a rippling stream, in which two cows are drinking. A short distance beyond a peasant walks along the shore, apparently to join two companions still farther away. A line of moderate-sized hills forms the horizon, and above is a summer sky with the light concentrated on a low line of cumuli.

Signed at the lower left, C. Troyon.

Height, 18 inches; width, 15 inches.

From H. Brame, Paris, 1881.

No. 41

\section{FRANZ VON DEFREGGER}

\section{GERMAN}

1835

\section{A BAVARIAN PEASANT}

A LIFE-SIZE study of the head of an old Bavarian farmer, wearing a broad felt hat turned up at the side, a collarless black coat, scarlet waistcoat and black silk stock around a narrow white collar. The face is in three-quarters view to the right, with the eyes turned slightly to the left. A mass of iron-gray hair falls nearly to his shoulders, and a sparse mustache and beard partly cover the lower part of the face.

signed at the upper left, F. DefregGer, '81.

Height, 211/2 inches; width, 151/2 inches. 
No. 42

GEORGE HENRY BOUGHTON, R.A. AMERICAN

$1834-1905$

\section{A BIT OF BLUE AND WHI'TE}

A HALF-LENGTH figure of a comely Dutch maiden, seated in the stern of a market boat. She wears an elaborate lace cap fastened with gold pins, a blue and white figured jacket, a deep blue kerchief and an olive-green apron with bib. Her left hand is supported on a huge umbrella with malacca stick and ivory head. A few cabbages lie on the thwart beside her, and other market boats are seen in the distance, each with its load of vegetables. The sky is covered with a gray haze, and in the horizon are seen the scattered houses of a village, a line of beach and distant meadows.

Signed at the lower left, G. H. Boughton.

From M. Knoedler \& Co., New York, 1882.

Height, 18 inches; width, 13 inches.

No. 43

C. BISSCHOP

DUTCH

1828-

\section{GRACE BEFORE MEA'T}

Ax old Dutch peasant woman and her daughter, about to share their frugal evening meal, are seated at a table corered with a white cloth. The old lady clasps her hands and bows her head, while the young woman, who has apparently just finished reading from the Bible, is engaged in cutting the bread in a pewter dish. In the foreground on the right is an elaborately painted cradle. The effect of the light is strong and concentrated, accentuating the head and shoulders of the girl and bringing into high relief the head and hands of the mother, and sharply touching here and there the various objects in the picture.

Signed at the lower right, Bisscirop.

II eight, 21 inches; length, 261/2 inches.

From M. KNoedier \& Co., New York, 1882. 
No. 44

\section{MAR'TIN RICO}

SPANISH

1850

\section{CAP MARTIN, MEN'TONE}

A pleasant beach partly covered with verdure sweeps around from the foreground to the left in the middle distance at the foot of a wooded hillside, dotted with villas and pleasant gardens. On the right in the foreground is a trestle work supporting a pathway and a rustic shelter under a group of trees. A few washerwomen are engaged in their task near a sandy bank, a donkey feeds nearby, and the landscape is enlivened here and there by figures of women and children. The wide expanse of sky is cloudless.

signed at the lower right, Rico.

From M. KNoeduer \& Co., New York, 1881.

Height, 161/2 inches; length, 28 inches.

No. 45

ÉMILE ADÉLARD BRETON

FRENCH

\section{LANDSCAPE}

Contemporary

THE motive is taken from one of the picturesque valleys in the Ardennes. From under a lofty and steep hill in the distance a small, shallow stream flows down to the left foreground. In the middle distance a rough country road crosses the stream over a stone-arched bridge, where a flock of sheep is gathered on their way to the fold. On the left, in the foreground, a rough, wooded hillside rises out of the picture, and on the right, across the valley, a few slender trees with sparse foliage rise against a distant hill and the sky. The time is early evening, and the sky is flooded with warm light from the sun, which is apparently below the horizon.

Signed at the lower right, Emine Bretor.

Height, 19 inches; width, 15 inches. 


\section{ALPHONSE M. DE NEUVILLE FRENCH \\ $1836-1885$}

\section{THE ATTACK}

A tRUMPETER of hussars, blowing a call, is dashing along at a gallop on a spirited black horse, his sabre and water bottle tossing in the air. Behind him rides a young officer with upraised sword, evidently having just given the order. for the bugle call. On the left are the figures of cavalrymen engaged in close conflict with the enemy. The group is strongly relieved against a sky covered with gray clouds, with the smoke of battle driving along the horizon.

signed at the lower right, A. DE Neuvicle, 1880.

Height, 211/2 inches; length, 331/2 inches.

From M. KNoedier \& Co., New York, 1882.

No. 47

\section{WILLIAM TROST RICHARDS}

AMERICAN

$1833-1905$

\section{A BIT OF JERSEY COAST}

\section{Water Color}

A BROAD expanse of the ocean covered with long lines of waves, which, as they reach the shallow beach, break into masses of foam. On the left the water laps the flat beach in long wavy lines, and shore birds hover about in search of food. On the right, in a passage of light along the horizon, are two or three sailing-vessels. The broad expanse of sky is completely covered with masses of summer clouds.

signed at the lower right, Wм. T. Richands, 1881.

Height, 22 inches; length, 36 inches.

From S. P. Avery, New York, 1881. 
No. 48

\section{VICTOR LAGYE}

\section{BELGIAN}

Contemporary

\section{THE HISTORIOGRAPHER}

SEATED at a large Gothic desk in a room of the same period is a young woman in the quaint costume of the time, with laced sleeves and bodice, and a tulle headdress. She is engaged in attentively examining manuscripts which are scattered over the desk and on the floor. In the background is a hooded fireplace, various shelves with books, a tall buffet with cupboard doors, and pewter platters.

Signed in the lower middle, V. LAGYE, 1870.

Height, 22 inches; width, 21 inches.

No. 49

\section{F'RIEDRICH VOLTZ}

\section{GERMAN}

$1817-1886$

\section{HARVEST TIME}

THE evening of a pleasant day in harvest time, and the farmers are driving their cattle home and carrying to their barns great loads of grain. In the foreground a large herd of cattle stops to drink at a shallow brook, crossed by a footbridge, on which stands a peasant woman carrying a basket on her head, with a small child by her side. On the left a clump of oak trees rises out of the picture, and on the right is an extent of sunlit country with a busy harvest scene and a roadside shrine.

Signed at the lower right, Friedr. Voltz, 1881.

Height, 18 inches; length, 44 inches.

From Wimmer \& Co., Munich, 1881. 
No. 50

\section{H. J. JOHNSTONE}

ENGLISH

Contemporary

\section{ON THE RIVER GOULBORN,}

VIC'TORIA, AUSTRALIA

ON the left of the composition a wide and quiet river sweeps around a point, and is lost in the extreme distance. In the foreground on the right is a tangled mass of trees rising from a low, stony shore, where a few naked natives bathe in the tepid water. The dense jungle which covers the river banks and the atmospheric effect suggest a moist, hot climate.

Signed at the lower right, H. J. Johnstone.

From the ARTist.

Height, 231/2 inches; length, 36 inches.

No. 51

\section{LÉON RICHET}

FRENCH

Contemporary

\section{LANDSCAPE}

A sANDy path leads from the distance past a small pool in an open glade, to the foreground, under scattered clumps of sturdy trees. The strong sunlight from the right flecks the rough trunks here and there, illuminates the figure of a peasant woman on the path, touches the autumn foliage in the middle distance and accentuates the grass and trees beyond. The foreground is in shadow, as well as the upper parts of the trees which rise on the right and left of the foreground.

Signed at the lower left, LÉON RICHET, 1881.

Height, 23 inches; length, $311 / 2$ inches. 
No. 52

\section{H. J. JOHNSTONE \\ ENGLISH \\ Contemporary}

\section{A BACKWATER OF THE RIVER \\ MURRAY, SOUTH AUSTRALIA}

ON the left is an irregular river bank, covered with a dense and tangled jungle, never disturbed by the touch of civilized man. In the foreground on the right, and extending partly across the foreground, is a shallow, quiet river, which extends to the extreme distance, where it curves around between two tree-covered points. Water lilies, weeds and fallen branches break the surface of the water in the foreground, and the tree forms along the bank, together with the warm-tinted clouds of a sunset sky, are reflected in innumerable ripples.

Signed at the lower left, H. J. JoHnstone.

From the ARTist.

Height, 231/2 inches; length, 36 inches.

No. 53

ALPHONSE M. DE NEUVILLE

FRENCH

$1836-1885$

\section{OFFICERS RECONNOITRING}

Two officers of Hussars, with their orderlies, have ridden to an advanced position to observe the movements of the enemy, and, leaving their horses in charge of the men, are earnestly studying the distance from the summit of a small knoll. In the immediate foreground a young orderly stands, with sabre in his left hand, holding in his right the bridles of a mottled gray horse and a brown one, the latter only partly visible behind the first. On the right a second soldier, still mounted, holds his companion's animal. The horizon is formed by a line of low, broken hills, and the bare trunks of slender trees rise against a sky which is accentuated by flecks of light from the setting sun.

Signed at the lower left, A. DE NEuvirle, 1882.

Height, 18 inches; length, 241/2 inches.

From M. KNoedlen \& Co., New York, 1882. 
No. 54

\section{ALFRED WAHLBERG SWEDISH}

$1834-$

\section{MOONLIGH'T ON THE FIORD}

From the left foreground a picturesque water front extends in perspective to the distance on the right. Fishermen's cottages, a rude plank walk, fish houses and similar structures occupy every yard of the shore. The moon breaks through the clouds near the zenith, and is reflected in the rippling waters of the harbor in a broad band of light, which extends out of the picture in the foreground. The sky is partly covered with large masses of vapor.

Signed at the lower right, AlF. WAHLLERG, 1882.

Height, 251/2 inches; length, 39 inches.

From M. Knoedler \& Co., New York, 1882.

No. 55

\section{A. THÉODULE RIBOT FRENCH \\ $1823-1891$}

\section{THE GUNMAKER'S APPRENTICE}

A wORKMAN in his shirt sleeves, with bare arms, holds to his mouth an old muzzle-loading flintlock pistol, apparently blowing down it to see if the vent is clear. The light falls upon the figure strongly from the upper left, throwing into prominence the head, the right arm and the shoulder. The background is a deep tone of brown.

Signed at the lower right, RIBot.

Height, 281/2 inches; width, 23 inches.

From Durand-Ruex, Paris, 1881. 


\section{No. 56}

\section{A. GAUBAUL'T FRENCH \\ Contemporary}

\section{PLANS}

Is the foreground, on a rough field covered with stones and stubble, are two officers engaged in examining a large plan or a map of the country. They have dismounted from their horses, which are held by orderlies, and behind them, just mounting the hill, is a small escort with an officer. On the left there is a wide view over a valley where a large encampment is seen on a low elevation, partly surrounded by irregular sheets of water. The lower part of the sky is entirely covered by clouds, and a few spots of blue show towards the zenith.

Signed on the lower right, A. Gaubault.

From M. Bernheim, Paris, 1881.

Height, 251/2 inches; length, 32 inches.

No. 57

\section{A. GAUBAULT}

\section{FRENCH}

Contemporary

\section{DESPA'TCHES}

A Mounted officer has just received at the hands of a Chasseur d'Afrique, who has dismounted from his tired steed, a despatch of some importance, and is earnestly conversing with the messenger. Behind the group stands a detachment of infantry, dusty from a long march, and in the extreme distance on the left, under a cloudless sky, is a rough hillside, crowned with a fortress around which a battle is raging. The motive is apparently taken from the Algerian campaign.

Signed on the lower left, A. Gaubautit.

From M. Bernheim, Paris, 1881.

Height, 251/2 inches; length, 32 inches. 


\section{GABRIEL MAX}

\section{AUSTRIAN}

$1840-$

\section{RAISING OF JAIRUS' DAUGHTER}

In the foreground, swathed in her grave-clothes, is the figure of the young girl extended on a rude couch. She is partly raised to a seated position by the Saviour, who, bending over her, clasps both her extended hands in his. The foreground, with the figure and its accessories, is in a strong effect of light, and in vivid contrast with the gloom of the background, in which the figure of the Saviour is dimly but suggestively visible. High on the wall to the right; over the bier, three flickering lamps send their faint glow upon an archway and a few simple objects.

signed at the lower right, GAB. MAx, 1881.

Height, 271/2 inches; length, 34 inches.

From Wimmen \& Co., Munich, 1881.

No. 59

\section{ADAM-KUNZ \\ GERMAN}

Contemporary

\section{STILL LIFE}

A cut watermelon, a pomegranate, walnuts and flowers, a half-opened basket filled with grapes, a silver ewer, a branch of grapevine with leaves and fruit, are arranged on a marble table in a strong effect of light. On the left a piece of purple drapery, on which are a few walnuts, falls over the moulded edge of the marble slab. 'The background is a rough wall, with a projecting cornice.

signed at the left, L. Adan-Kunz.

Height, 261/2 inches; length, 401/2 inches.

From Wimmen \& Co., Munich, 1881. 
No. 60

DANIEL RIDGWAY KNIGH'T

AMERICAN

1850 -

\section{HAYING TIME-SCENE NEAR POISSY:}

THE COUN'TRY SEAT OF MEISSONIER

Four sturdy peasant girls, dressed in coarse garments, have been cutting with sickles the rank herbage in a field, and are resting from their labors before carrying their burdens to the distant village. The freshly cut grass is gathered in large bundles for convenient handling. A ploughman, seated on his horse, pauses in the road, beyond the group, to talk with one of the girls. On the right, in the distance, is a view over a wide expanse of flat country. The sky is filled with soft summer clouds.

signed at the lower right, D, Ridgway KNight, Paris, 1881.

Height, 271/2 inches; length, 36 inches.

From M. Knoedler \& Co., New York, 1881.

No. 61

JOHN E. C. PE'TERSON

AMERICAN

$1839-1874$

\section{U. S. FRIGATE MONONGAHELA}

ON the left, near the foreground, the well-known frigate, under topsails and spanker and jib, is steaming along in a light air through a summer sea. She is apparently about to take a pilot aboard, for a small boat, filled with darkskinned natives, is just crossing her bow with the intention of boarding her. On the horizon are seen the lofty pinnacles of an immense crag in the warm haze of the southern sky, and on the left is a second frigate, with sails clewed up, steaming along quietly in the wake of the first one.

Signed at the lower right, John E. C. Peterson, 1869.

Height, 28 inches; length, 40 inches. 


\section{ALFRED VON WIERUSZ KOWALSKI POLISH}

1849

\section{ON THE ROAD TO THE HUN'T}

Is the foreground, at the fork of a very muddy road, stands a rude wagon drawn by three horses, and surrounded by sporting dogs coupled together and attached to the vehicle. A stolid old gentleman, with gun and pipe, and his favorite dog beside him, sits snugly in the straw and hay with which the wagon is filled. Beyond, on the right, his companion is seeking refreshment at a roadside inn. In the distance are several thatched cottages and a line of low trees beyond a rough, rolling country. The sky is covered with dark gray clouds, with here and there a reflection from the morning sun.

signed at the lower right, Alfred v. Wierusz Kowalski.

Height, 281/2 inches; length, 47 inches.

From M. KNoedler \& Co., New York, 1881.

No. 63

\section{EMILE LAMBINE'T \\ FRENCH}

$1815-1878$

\section{LANDSCAPE}

A typical view of a pleasant French river. On the right is a steep, verdure-covered bank, sloping to a muddy shore, where is moored a rough fishing-boat near a rude pier, on which are seen three peasants, one with a fishing pole. Across the river a rank of poplars and other trees surrounds and shades large farm buildings, and to the right, rising high against a luminous sky, is a densely wooded hill. The sun is high in the heavens, and the light is concentrated on a brilliant cloud at the top of the picture to the right.

Signed at the lower left, Émile Lambinet, 1875.

Height, 29 inches; length, 51 inches. 


\section{PROFESSOR ALBERT BAUR \\ GERMAN}

$1835-$

\section{A ROMAN BANQUET}

THE festival of Bacchus is being celebrated in a Roman house, and grouped around the master, who is crowned with vine leaves, are musicians and attendants. The lord of the feast holds in his lap a golden bowl, into which an African slave is pouring wine from a slender amphora. Nearby are a youth and maiden decked with the emblems of Bacchus, and on the left attendants are bringing viands for the feast. On the right through an opening, where a slave draws aside the curtain, is seen the triclinium, where various revellers are feasting and drinking.

Signed at the lower right, AlB. Baur. Height, 29 inches; length, 47 inches.

From M. KNOEdLeR \& Co., New York, 1882.

No. 65

\section{PAUL HAGELSTEIN GERMAN}

Contemporary

\section{THE LITTLE FLOWER GIRL}

NeAr the entrance of a theatre, presumably in Paris, stands a barefooted little girl in a ragged dress, her shoulders enveloped in a shawl and her head in a white kerchief. She holds on her left hip a basket of flowers, partly covered by a towel, and in her extended right hand a small bouquet, which she offers to the passer-by. A strong flood of sunlight brings the figure into contrast against the rough wall. Behind her are seen various playbills pasted one above the other.

signed at the lower left, PaUL Hagelstein.

Height, 291/2 inches; width, 22 inches. 


\title{
LOUIS BRÜCK-LAJOS \\ HUNGARIAN \\ 1846-
}

\section{THE YOUNG SAVOYARD}

A study, nearly life-size, of a roguish-looking young Savoyard in well-worn costume consisting of a sheepskin jacket over velveteen coat and breeches, and a black steeple-crowned, feather-trimmed hat, which partly shades his roguish face. In his left hand he holds a half-eaten apple, and his right arm rests upon a basket of the same fruit. In the background is a clump of trees against the summer sky.

Signed at the louer left, Brück-LaJos.

Height, 30 inches; width, 23 inches.

From M. K Noeduer \& Co., New York, 1882.

No. 67

\section{FERDINAND ROYBE'T}

\section{FRENCH}

\author{
1840 -
}

\section{THE STANDARD BEARER}

A RICHLy dressed standard bearer, of the time of Louis Quatorze, stands holding in his right hand his broad felt hat, and in his left a richly embroidered standard. He is dressed in a white brocaded doublet, girdled with a yellow sash, striped blue breeches, jack boots. Around his neck is a deep ruff, and across his shoulders a broad embroidered band. In the background are various characteristic objects of the time, and in the immediate foreground a few playing cards are strewn upon the stone floor.

signed at the lower left, F. RoувEт.

From Arnold \& Tripp, Paris, 1881. 
No. 68

\section{FREDERICK E. CHURCH, N.A.}

\section{AMERICAN}

$$
1826-1900
$$

\section{MORNING IN THE TROPICS}

Extending across the foreground and sloping up to the left is a grassy bank covered with rich vegetation and crowned by a dense mass of tropical trees. Beyond, and extending across the picture to the right, is a placid sheet of water with a pleasant wooded island. The lake is bounded on the farther shore by a series of terraced, irregular hills extending to a mountain range in the far distance. The sun has just risen above a bank of thin clouds, and is brilliantly reflected on the waves of the lake, sending a warm glow over the entire landscape.

Signed at the lower middle, F. E. Снurch, 1872.

Height, 30 inches; length, 381/2 inches.

No. 69

\section{WILLIAM ADOLPHE BOUGUEREAU}

\section{FRENCH}

$1825-1905$

\section{THE PET BIRD}

A Half-Length figure of a fair-haired young girl, who leans on a table, holding her pet bullfinch perched on the forefinger of her left hand. She is dressed in a blue silk gown with low bodice and a diaphanous muslin blouse, tied at the wrists with black ribbons. The background is the wall of a decorated room.

Signed at the left, W. Bouguereau, 1867.

Height, 32 inches; width, 26 inches. 


\section{FERDINAND HEILBUTH \\ GERMAN \\ 1826-1889}

\section{CONTEMPLATION}

Recuining on the bank of a placid stream a fashionably dressed young lady contemplatively gazes at the water. The figure is foreshortened and mostly hidden behind the declivity of the bank, so that only the upper part shows. On the left a stately clump of trees forms a prominent feature in the composition, and beyond, in the extreme distance, a wooded hill suggests a pleasant farming country. The scene is lighted by a soft diffused light from the sky, covered with thin soft summer clouds.

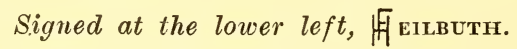

Height, 361/2 inches; width, 22 inches.

From Arnold \& Tripp, Paris, 1881.

No. $\% 1$

\section{LÉON RICHET}

FRENCH

Contemporary

\section{AT THE WELL}

Two young peasant women, in coarse garments and wooden shoes, are drawing water at a well. One of them is pouring water from a metal bucket into an earthen jar; the other, seated on the stone curb, is waiting her turn. Behind the figures is part of a masonry structure protecting the well, and trees and foliage. On the right is a glimpse of a sunlit wheat-field.

Signed at the lower right, LÉox Richet, 1881.

Height, 35 inches; width, 26 inches.

From M. KnoedLer \& Co., New York, 1882. 
No. 72

\section{EDWIN LORD WEEKS}

\section{AMERICAN}

$1849-1903$

\section{A HALT AT THE FOUNTAIN}

In the foreground near a street fountain are two camels, one with a rider who raises a glazed earthen jar of water to his lips. Standing near are two richly dressed natives, and beyond them a third stoops over to draw water from a fountain. An elaborately carved wooden arch and cornice, in Moorish style, dominates the group and casts a deep shadow over the location where the fountain stands. Two storks, with their nest, are seen on the coping of a rough wall which extends across the picture to the right.

Signed at the lou'er right, E. L. WEEKS, 1881.

Height, 391/2 inches; width, 25 inches.

From Durand-Ruel, Paris, 1881.

No. 73

\section{PHILIPPE ROUSSEAU}

\section{FRENCH}

$1816-1887$

\section{THE HERON AND THE SNAIL}

A LARGE gray heron, painted the size of life, stands on a muddy shore, holding with one foot a snail shell, which the immense bird is about to attack with its long, pointed beak, illustrating the well-known fable. 'The background is a broad extent of marshy country, with a sombre sunset sky.

Signed at the lower right, PH. Rousseau.

Height, 38 inches; width, 30 inches.

From Arnold \& 'Tripp, Paris, 1881. 


\section{PHILIPPE ROUSSEAU \\ FRENCH \\ $1816-1887$}

\section{THE COCK AND THE PEARL}

A Magnificent specimen of a game-cock, with brilliant plumage, ruddy comb and wattles and iridescent tail feathers, holds in his beak a pearl which he has just taken from an oyster shell, which is half concealed in a pile of straw at the foot of a rough wooden fence. The bird is lighted by a flash of sunlight, which brings the rich colors of his plumage into strong contrast against the gray of the earth, the deep tones of the fence and the cloudy sky beyond.

Signed at the lower left, PH. Rousseau.

IIeight, 371/2 inches; width, 30 inches.

From Anxold \& Tripp, Paris, 1881.

\section{No. 75}

\section{ADOLF SCHREYER GERMAN}

1828-1899

\section{BULGARIAN SMUGGLERS}

ON a rough rocky eminence a band of Bulgarian smugglers, with their shaggy, unkempt horses, have halted on one of their unlawful excursions. A strong gale is blowing, and the horses are huddled together for shelter, while two of the smugglers are seated on the rocks nearby, in attitudes of patient expectation. 'On the right of the scene, beyond a pony scrambling breathlessly to the summit, is a view over a sunlit plain, with a dimly seen collection of buildings, evidently the first frontier town.

Signed at the lower right, Ad. Schrexer.

Height, 331/2 inches; length, 55 inches.

From William Sciraus, New York, 1881. 
No. 76

\section{ALBER'T BIERSTADT}

\section{AMERICAN}

$1830-1902$

\section{SIERRA NEVADA}

THE motive of this picture is taken from the range of mountains, near the Pacific Slope, which was the artist's favorite field of study. In the foreground is a sloping bank with wigwams and Indians, and beyond, a placid sheet of water, surrounded by lofty cliffs. Still farther away immense crags, with snow-fields and glaciers, rise high among the clouds.

Signed at the lower right, ABIErstait, ' 71.

Height, 36 inches; length, 54 inches.

No. 77

\section{UNKNOWN}

\section{DOGS AND GAME}

A sETTER and a pointer are keeping guard over a pile of dead game at the foot of a boulder on a rough hillside. Pheasants, partridges, a hare, and a game bag filled with other birds, are piled together in confusion in the foreground, and close at hand and behind them sit the two dogs, apparently watching the approaching of their master. The dogs and birds are natural size. In the upper lefthand corner is a glimpse of landscape with trees in full autumn foliage. 
No. 78 .

\section{MIHALY MUNKÁCSY \\ HUNGARIAN}

$1846-1903$

\section{THE LAST HOURS OF A}

\section{CONDEMNED MAN}

Seated at a rude table in a strong dungeon is a Hungarian peasant, his legs shackled together with a heavy chain, with clenched hands and lowered head, contemplating his fate. The table, on which two lighted candles are placed, is spread with a white cloth, and beyond, in the gloom of the interior, stands a soldier with musket and bayonet. In the foreground on the right is a torn book, carelessly thrown upon the floor, and on the left a rough copper dish partly filled with food.

Signed at the lower left, MÚNKacsY, M.

Height, 31 inches; length, 391/2 inches.

From S. P. Avery, New York, 1881.

No. 79

\section{JULES BERTRAND GELIBER'T}

\section{FRENCH}

1834 -

\section{AT THE RENDEZVOUS}

Four couple of hunting dogs are tethered to a tree near the guns and game bags of a hunting party, which have been deposited on a rock by a woodland path. In the background is a tangle of tree trunks and bushes, and a narraw strip of sky, broken by branches and foliage, extends across the top of the picture. The foreground is in shade and the dogs in a strong effect of sunlight.

signed at the lower left, JuLES GÉLIBERT, 1881.

From Messis. Goupir, Paris, 1881.

Height, 371/4 inches; length, 49 inches. 


\section{KARL LUDWIG FRIEDRICH BECKER GERMAN}

$1820-$

\section{SAPPHO}

A Half-Lengre, life-sized figure of a dark-haired, blueeyed maiden, holding with her left hand an inlaid and ornamented Greek harp, the strings of which she touches with the fingers of her right hand. A gold-bordered tunic is girdled to her waist by a golden strophion, and an embroidered blue mantle is draped over her left shoulder and arm. A wreath of laurel leaves crowns her mass of rich brown hair. A double necklace of gold coins and a large brooch on either shoulder are the only ornaments she wears. The background is a graded tone of warm brown, and on the right side is a variegated marble column on a white marble base.

Signed at the lower left, K. BECKER, 1881.

Height, 431/2 inches; width, 301/2 inches.

No. 81

\section{PAUL JEAN CLAYS}

BELGIAN

$1819-1900$

\section{ON THE ZUYDER ZEE}

ON the left is a group of three bluff-bowed Dutch freight boats, and on the right, near a low shore, are similar craft in the middle distance. In the near foreground fishermen in a clumsy boat are casting a seine. It is a calm summer day, and the tones of the sky, the brilliant hues of the sails and the dark masses of the boat hulls are accurately reflected in the smooth waters. The horizon is a low strip of land, broken here and there by a distant sail, and a lofty sky full of soft clouds overhangs the landscape.

signed at the lower right, P. J. Clays. Height, 30 inches; length, 53 inches.

From Arnoln \& Tripp, Paris, 1881. 
No. 82

\section{HERMANN HERZOG GERMAN}

$1832-$

\section{MOUN'TAIN STREAM AND MILL}

A NARRow, winding mountain torrent dashes down to the right foreground through rocky banks. On the left is a rude mill, with overshot wheel, and beyond it, among the trees, are cottages standing on the river bank. In the immediate foreground is a fisherman and a peasant woman with a child. A lofty sky is partly covered by immense masses of cumuli.

Signed at the lower left, H. Henzog, 1866.

Height, 43 inches; width, 37 inches.

No. 83

\section{EDUARD GRÜ'TZNER}

GERMAN

$1846-$

\section{TRIO IN THE MONASTERY}

A RICH interior of a Dominican monastery, in which are assembled several monks in their characteristic robes. Three of them are engaged in playing from a musical score, supported on a carved lectern, while the others listen with absorbed interest. The group is strongly lighted from a leaded window on the left. The background is a panelled wall, with a carved frieze, two cupboard doors with ornamental iron work, a shelf with books and other objects, a map and a painted decoration.

Signed at the lower right, Eduard Grützaner, 1881.

Height, 40 inches; width, 361/2 inches.

From E. A. Fueischunan, Munich, 1881. 


\section{VACSLAV VON BROŽIK}

\section{AUSTRIAN}

1852-1901

\section{THE UNCLE'S VISIT}

IN the rich interior of a seventeenth-century mansion is assembled a family to welcome the visit of a favored and apparently wealthy relative. The visitor, in a complete suit of red velvet, sits near a table in earnest conversation with the mother, while the father and the children listen attentively. A maiden in a white satin gown brings in a salver with a rich flask of wine and a silver cup. In the background are richly carved cabinets and a tapestry-draped canopy bed.

Signed at the lower right, В Вог̌̌r.

Height, 37 inches; length, 55 inches.

From M. KNoedLer \& Co., New York, 1882.

\section{No. 85}

\section{H. J. JOHNSTONE ENGLISH \\ Contemporary}

\section{A BACKWATER OF THE RIVER}

MURRAY, SOUTH AUSTRALIA

Partly covering the foreground and extending to the extreme distance is a quiet strip of water reflecting a tropical, cloudless sky and the trunks and foliage of the trees along its low banks. In the foreground immense trees, showing great age, extend out of the top of the picture, and on the right bushmen are engaged in preparing a meal in the shelter of a rude hut.

Signed at the lower right, H. J. Јонмsтone, 1881.

From the ARTisT.

Height, 48 inches; length, 72 inches. 
ANTOINE CHARLES HORACE VERNET

\author{
(Called CARLE)
}

FRENCH

$1758-1836$

\title{
A ROMAN TRIUMPH
}

THE composition represents the triumph decreed to the Roman General Paulus Aemilius after his successful campaign in Macedonia. A long procession, headed by the victorious legionaries guarding the spoils taken from the conquered and bearing the military insignia of the Macedonian leaders, is passing along the Via Sacra through monumental arches to the broad approach to the Capitol. On the extreme right of the picture, which contains hundreds of figures, is the Greneral himself, in gorgeous robes, seated on a throne on the platform of a golden chariot, decked in the insignia of Jupiter Capitolinus, and with the figure of a winged Victory holding a wreath of laurel above his head. The chariot is drawn by four prancing white horses, and followed by a crowd of the vanquished, among them Perseus in mourning robes, who is preceded by his daughter and two sons. Dancing girls, musicians, horsemen and foot soldiers complete the procession. In the background is a range of hills crowned with stately edifices, chief among them the temple of Jupiter Capitolinus, with its grand approach of a hundred steps.

This important picture was found in Europe by $\mathbf{M r}$. Bishop some fifteen years ago. Although it was in bad condition, the subject unrecognizable and the painter unknown, he purchased it and brought it to this country. The remarkable qualities of the painting were disclosed after the canvas was restretched and cleaned, and the discovery of the artist's signature established its identity as the chefd'œuvre of Antoine Charles Horace Vernet, commonly 
called Carle Vernet, the son and pupil of Joseph Vernet. The picture is dated 1789, which is the date of Carle Vernet's election to the French Academy in recognition of the superior merits shown in his painting of "The Triumph of Paulus Aemilius." A study of the composition shows that the artist endeavored to epitomize the events of the three days of triumph, one of the most notable events of the kind in the history of Rome, and the only triumph in which its dignity was not marred by the display of booty which the soldiers had been permitted to loot from the enemy without restriction or hindrance. The works of art, weapons and insignia brought to Rome by Paulus Aemilius were appropriated for the use of the nation and not for private aggrandizement. It will be observed in the picture that the army is represented only by a sufficient number of soldiers to guard the rich works of art and to carry the captured armor and standards. The hero of the triumph himself bears the eagle-crowned sceptre and wears the laurel wreath which are the recognized insignia of Jupiter Capitolinus. Immediately behind the chariot are the two sons and the daughter of Perseus, escorted by various chiefs and attendants, and followed closely by the conquered king himself in mourning robes, herded in the crowd like a common captive. The character of the composition, briefly suggested above, no less than the unusual importance of the picture and the extraordinary qualities of execution, establishes its identity beyond reasonable doubt. Further, no other painting by the artist, illustrating this or a similar subject, is known to exist.

Signed at the lower left, CARLE VERnET, 1789.

Height, 50 inches; length, 171 inches. 



\title{
CATALOGUE
}

\author{
FIRST AFTERNOON'S SALE \\ WEDNESDAY, JANUARY 1\%тн, 1906 \\ AT THE AMERICAN ART GALLERIES
}

BEGINNING AT 2.30 o'CLOCK

\section{SWORD GUARDS (TSUBA)}

\section{1-TWO IRON SWORD GUARDS}

(a) Openwork design: leaves and insects. By Tomotsugu, and signed.

(b) Openwork design: puppy playing with shell tied to a string.

2-IRON SWORD GUARD

Rooster in openwork, and inlaid with gold. By Tomotsugu, of Hagi.

\section{3-IRON SWORD GUARD}

Relief ornamentation: monkey on pine branch, frightened at his reflection cast by the moon on stream. Reverse, pine tree etched and in low relief. By Hō-yen, and signed.

\section{4-TWO IRON SWORD GUARDS}

(a) Plum tree in blossom in openwork. By Toshimasa, of Mushashi.

(b) Fan-shaped panels with relief ornamentation incrusted with gold. By Masachika, and signed. 
5-LARGE SWORD GUARD

Iron; fan-shaped. Dragons amid cloud forms in openwork. Signed, Bushiu-ju Masachika.

\section{6-IRON SWORD GUARD}

Decoration of millet in low relief, and incrusted in gold on obverse. Sun breaking through clouds on reverse. Signed, Issai Tomei.

7-TWO IRON SWORD GUARDS

(a) Dragon in openwork.

(b) Dogs and shells in openwork.

8-TWO IRON SWORD GUARDS

(a) Bold relief ornamentation: Shōki pursuing demon who has stolen the temple lantern.

(b) Stork and wave design in relief casting, forming an outer border.

\section{9-TWO IRON SWORD GUARDS}

(a) Openwork design: basket of flowers and garden implements.

(b) Genii astride carp, and wave designs in openwork.

10-TWO IRON SWORD GUARDS

(a) Crudely shaped. Monkey fishing by moonlight, in incrusted gold, copper and other metals.

(b) Rough surface heavily plated with gold.

\section{1-TWO RED BRONZE SWORD GUARDS}

(a) Ornamented with three heart-shape relief panels, in which are landscapes, in various metals.

(b) Monkey on pine tree reaching for reflected crescent in stream; wrought in relief in shakudo, gold and copper.

12-TWO IRON SWORD GUARDS

(a) Plum in blossom in relief casting and inlaid with silver and gold.

(b) Branches of tree peony in gold damascene on obverse and reverse. 


\section{3-TWO GOROSA BRONZE SWORD GUARDS}

(a) Flower cart finely wrought in relief in shakudo and gold. On reverse a single floral spray.

(b) Shape of sake jar, with figure of sake imp on top; inlaid with gold and other metals.

\section{4-TWO IRON SWORD GUARDS}

(a) Daruma, vines and war baton, in relief casting in shibuichi and gold.

(b) Dragon emerging from clouds, wrought in relief in silver.

15-TWO SHIBUICHI SWORD GUARDS

(a) Fabulous animals in relief in gold and shakudo.

(b) Flowering shrubs and crescent, in relief in gold and shakudo.

16-TWO IRON SWORD GUARDS

(a) Silver dragon emerging from clouds.

(b) Lotus leaves, insects and shells in gold, shakudo and red bronze.

17-TWO GOROSA BRONZE SWORD GUARDS

(a) Cherry tree in blossom, bamboo, dragon and tiger in openwork and gold inlay.

(b) Scene illustrating rice culture, in relief casting in gold and silver; gilt edge.

18-TWO IRON SWORD GUARDS

(a) Artistic ornamentation: geese by river side in moonlight.

(b) Dragon amid cloud forms in relief casting and gilt.

19-TWO IRON SWORD GUARDS

(a) Openwork design of cherry blossoms; slight gold inlay.

(b) Dragon, etched and gilt; gold and silver clouded surface.

20-TWO SWORD GUARDS

(a) Shakudo. Sheaves of rice and scarecrow in gold; reverse, streàm and grasses in gold and silver.

(b) Iron, with surface in imitation of wood grains; tethered cows and kiri crest in shakudo, gold and silver. 
21-TWO GOROSA BRONZE SWORD GUARDS

(a) Dragon, tiger, cherry-tree in blossom and bamboo in openwork.

(b) Surface in imitation of wood grains; dragon crests in gold.

22-TWO IRON SWORD GUARDS

(a) Dragon emerging from clouds, in relief in silver.

(b) Landscape, river view and snow-clad mountains in low relief, and inlaid with gold, silver and other metals.

23-TWO IRON SWORD GUARDS

(a) Grotesque figures incised and inlaid with gold and copper.

(b) Kiri and phœnix, in relief casting in gold and silver.

24-TWO SHAKUDO SWORD GUARDS

(a) Basket work surface, with floral vine in gold incrustation.

(b) Dragon crests and cloud forms in gold inlay.

25-TWO IRON SWORD GUARDS

(a) Ornamented with scene representing an emperor in royal cart, guarded by a dragon from an attacking mounted warrior. Carved and inlaid with gold and silver.

(b) Figure in garden, mountain scenery and river view, in relief casting and gold and copper incrustation.

26-TWO IRON SWORD GUARDS

(a) Japanese legendary subject, in openwork and gold and silver incrustation.

(b) Demon, animal and plants, in openwork and gold inlay.

27-TWO SHIBUICHI SWORD GUARDS

(a) Shōki and attendant looking at cascade; wrought in relief and inlaid with gold and shakudo.

(b) Shell design, inlaid with precious metals.

28-TWO SWORD GUARDS

(a) Iron. Dragon emerging from clouds, wrought in relief in silver.

(b) Shibuichi. Branch of plum blossom, duck and other designs in gold and silver incrustation. 
29-TWO SWORD GUARDS

(a) Shibuichi; bold tiger by waterfall wrought in relief and inlaid with gold. Reverse, a dragon, amid cloud forms, clutching the Sacred Pearl.

(b) Iron. Shōki, with scroll, by a stream; demon holding aloft a banner, wrought in relief in gold, shakudo and red bronze.

30-TWO IRON SWORD GUARDS

(a) Well bucket, birds in flight and other designs in gold and shakudo.

(b) Landscape and rain-storm, in relief casting, with incised and gold inlay; bronze edge.

31-TWO IRON SWORD GUARDS

(a) Wild goose descending to stream, in relief in shakudo and silver; reverse, silver crescent.

(b) Rampant horse, pine tree and mountain scenery in low relief.

32-TWO IRON SWORD GUARDS

(a) Figures of a wandering minstrel and wife, Dog Foo and pine tree, in openwork and gold and copper bronze.

(b) Golden carp ascending waterfall, in openwork.

33-TWO SWORD GUARDS

(a) Shakudo; flowering shrubs in relief in gold and other metals.

(b) Gorosa bronze. Tree peonies and Dogs Foo in enamel and relief casting.

34-TWO IRON SWORD GUARDS

(a) Laborer by seashore under a pine tree, torii and lantern in low relief.

(b) Priest, horse, pine, cloud forms and mountains in low relief.

35-TWO SHAKUDO SWORD GUARDS

(a) Crest-shaped; floral vines in gold incrustation.

(b) Golden dragon amid cloud forms chasing the Pearl of Omnipotence. 
36-TWO SHAKUDO SWORD GUARDS

(a) Dragon in gold, amid cloud forms.

(b) Numerous fan and heart shape medallions, incised and inlaid with gold.

37-IRON SWORD GUARD

Hexagonal shape. Dragon, priest, horse and pine tree, in openwork and gold inlay. By Kanenari, near Lake Biwa. Early eighteenth century.

38-TWO SWORD GUARDS

(a) Bronze. Chrysanthemums and winding stream finely wrought in relief and openwork; petals of gold inlay.

(b) Iron. Crests in gold damascene.

39-TWO IRON SWORD GUARDS

(a) Mice and camel in relief, in bronze, shakudo and shibuichi.

(b) Bold dragons around the edge in relief casting and chiselled.

40-IRON SWORD GUARD

On metal-work stand; guard of openwork and relief casting. A mounted warrior resting beneath pine tree. Sword tip inserted in centre.

41-TWO IRON SWORD GUARDS

(a) Priest, bamboo and pine, in relief casting and gold and silver.

(b) Daruma, in relief and gold and copper bronze incrustation.

42-TWO IRON SWORD GUARDS

(a) Dragon in openwork; edge of Grecian key pattern in silver inlay. By Tomo-yoshi.

(b) Branch of blossoms in openwork. By Rokuroyemon.

48-TWO IRON SWORD GUARDS

(a) Lotus and frog in relief casting and gold and red bronze. By Yen-ju.

(b) Gourd vine in low relief and gold incrustation. By Umetada. 
44-TWO IRON SWORD GUARDS

(a) Bold frog design in relief casting. By Mune-hide. Early eighteenth century.

(b) Dragons in high relief. Cast and chiselled. By Kinai. Eighteenth century.

\section{5-IRON SWORD GUARD}

Japanese legendary subject, cast in high relief and incrusted in gold and silver. Signed by Ju-kio (Minamoto), of Koshiū.

46-TWO IRON SWORD GUARDS

(a) Daruma and inscriptions in relief casting, and gold and silver inlays. Design after Seshu.

(b) A blind street musician led by his dog; cast in high relief and incrusted with gold. By Nao-Shige (Okamoto).

\section{7-TWO IRON SWORD GUARDS}

(a) Lotus leaf design, in openwork. By Kinai.

(b) Vine and leaf design in openwork. By Hisa-tsugu.

48-TWO IRON SWORD GUARDS

(a) Dragon-flies in high relief and inlaid with gold and silver. By Toshi-teru.

(b) Deer by stream, grasses, flowers and rock, cast in low relief, chiselled and incrusted with gold. By Sho-ku (Sekiyosai).

\section{9-TWO SWORD GUARDS}

(a) Wood, lacquered in imitation of shakudo. Geese by stream, in gold and silver lacquer. Reverse, full moon emerging from clouds, and geese in flight over the sea. By Joka.

(b) Iron. Shōki on rocky cliff watching a dragon. By Tetsu.

50-TWO IRON SWORD GUARDS

(a) Elaborate ornamentation, in relief and gold and silver incrustation: the famous poets. By So-ten. Signed, Soheishi Niudo Soten.

(b) Equestrian and other figure and pine tree by the seashore, cast in high relief and incrusted with gold and silver. By So-ten. Signed, Koshiū Hikone-jū. 
51-TWO IRON SWORD GUARDS

(a) Sacred elephant and inscription in relief, incised and gilt. By Yasuchika.

(b) 'Tiger and bamboo in relief casting and gold inlay. By Masatsugu (Tachibana).

52-TWO SWORD GUARDS

(a) Iron. Collection of masks in openwork. Fine example by Kinai. 1700.

From the Brayton Ives Colnection, Catalogue No. 4.78.

(b) Shakudo. Magnolia in bloom, in relief in silver. By Seizui.

\section{3-TWO IRON SWORD GUARDS}

(a) Iron, of hexagonal shape and sofe finish. Decoration artistically wrought in relief and chiselled. Three geese among grasses in moonlight, bills and feet of incrusted gold; silver moon above. Reverse: Young geese nestled in bamboo grass. Signature and gold seal of Royen Itsu-jiu.

(b) Iron. Two monkeys on rock watching waterfall; finely wrought in high relief. Reverse, the sea, with monkey on raft and rocky cliff, in relief and chiselled. Signed by Shiyuchin.

54-TWO IRON SWORD GUARDS

(a) Old coins, in gold, silver and shakudo. By Shoami-Shigenobu. 1640-1690.

(b) Iron. Jingasa design of skilful workmanship. Signed by Hidetoshi. 1620-164\%.

55-TWO IRON SWORD GUARDS

(a) Daruma and inscriptions in incrusted gold, silver and copper bronze. Design after Sesshū.

(b) Monkeys, rocks and sea. Modelled in high relief and chiselled. Signed by 'Tomo-nobu.

56-TWO IRON SWORD GUARDS

(a) Storks amid cloud forms in open chiselled work. By Masanaga, Akasaka school.

From the Brayton Ives Collection, Catalogue No. 494.

(b) Openwork leaf design. By Kinai. 
57-TWO IRON SWORD GUARDS

(a) Octagon shape; elaborate dragon designs in relief and pierced work, and chiselled; gilt edge. Signed by Yeikō.

(b) Hammered surface. Butterflies in gold, shakudo and copper bronze. By Riū-ichi.

58-TWO IRON SWORD GUARDS

(a) Flowers and insects in fine openwork. Signed, Tomo-kiyo.

(b) Rice straw and grasshoppers skilfully cut in openwork. By Okado Masotomi, of Hagi Choshin.

From the Brayton Ives Collection, Catalogue No. 474.

\section{9-TWO IRON SWORD GUARDS}

(a) Kiri crest, in openwork, and chrysanthemum crest and vines in gold and enamels. By Umetada, 1650.

From the Brayton Ives Coliection, Catalogue No. 496.

(b) Dragon rising from the sea, skilfully wrought in relief and openwork, and chiselled. By Kiomasa.

From the Brayton Ives Colnection, Catalogue No. 486.

60-TWO IRON SWORD GUARDS

(a) Shell design in fine openwork. By Kinai.

From the Brayton Ives Collection, Catalogue No. 482.

(b) Of light texture. Dragon in openwork. By Kinai.

61-TWO IRON SWORD GUARDS

(a) Two poets with scroll, under pine tree, incised and slightly inlaid with gold. By Masa-fusa.

(b) Demon, in bold relief, in gold, silver and other metals. Reverse, grasshopper and inscription. By Toshi-taka.

62-TWO IRON SWORD GUARDS

(a) Tiger near stream, in relief casting and gold and silver incrustation; reverse, bamboo grove incised. By Nao-tora.

(b) Books, scroll and falling leaves in gold and silver incrustation. By Taku-shige. 
63-TWO IRON SWORD GUARDS

(a) Dragon amid cloud forms, wrought in relief in silver and gold. By Riusendo Shikau.

(b) Dragon-fly in winding stream, wrought in gold and silver, and gilt edge. By Tada-nori.

64-TWO IRON SWORD GUARDS

(a) Dragon, in openwork. By Kinai, of Yechizen.

(b) Daruma, in relief casting; very rare example. By Kaneiye.

From the Brayton Ives Collection, Catalogue No.466.

65-TWO SWORD GUARDS

(a) Iron. Jurojin and turtle of longevity, in relief casting and gold and silver. Signed by Masa-toshi.

(b) Shibuichi. Cock on temple drum, in relief in gold, shakudo and red bronze; reverse, old tree and vine. By Masa Yuki.

- From the Brayton Ives Collection, Catalogue No. 486.

66-TWO IRON SWORD GUARDS

(a) Figures, pine tree and waterfall, in openwork and gold inlay. By So-ten. Eighteenth century.

(b) Companion to the preceding. By So-ten. Eighteenth century.

67-TWO IRON SWORD GUARDS

(a) Japanese legendary subject: Daimio by seashore, playing flute; full moon emerging from clouds. Reverse, pine tree and waterfall. By Katsu-mori.

(b) Laborer resting under pine tree, wrought in relief, incrusted with gold. By Mune-ari.

68-TWO IRON SWORD GUARDS

(a) Hōwō bird and kiri leaves, damascened in gold and silver. By Naga-shiro.

(b) Mountain and river scenery, modelled in relief and chiselled. By Tomo-hisa. 
(a) Figure of sage, tiger and plum tree, in relief casting and incrusted in gold and silver. By Ziuzui.

(b) Bird in flight, waterfall and grasses, chiselled in relief and incrusted in gold and silver. By Nao-taka.

\section{O-IRON SWORD GUARD}

Of soft finish. Decoration of royal archer killing a deer, wrought in high relief in gold, silver, shakudo and red bronze. Reverse, maple tree by winding stream. Signed by Su-zuki Katsuyō.

\section{1-TWO IRON SWORD GUARDS}

(a) Japanese pilgrim, maple tree and waterfall, wrought in relief in various metals. By Yoshi-mitsu.

(b) Tiger, plum and bamboo, wrought in relief in gold and yellow bronze.

72-TWO IRON SWORD GUARDS

(a) Faggot gatherer leading cow, and cherry tree in blossom, finely wrought in relief in gold, silver and shakudo. By Masa-oki. (b) Of fine texture, made by Nohukuni Yoshimare, of Chikuyu. Ornamentation representing the lion dance. By Tokuoki, of Kioto.

From the Brayton Ives Coliection, Catalogue No. 467.

\section{3-TWO SHAKUDO SWORD GUARDS}

(a) Hexagonal shape. Dragons amid cloud forms, wrought in high relief, silver and gold. By Hide-Katsu ('Tokuno).

(b) Turtles of longevity and waterfall, chiselled in relief and incrusted in gold and silver. By Masa-tsune (Ishiguro).

\section{4-GOROSA BRONZE SWORD GUARD}

Elaborate decoration, representing Otafuku driving the devil away from her house by throwing peas at him. Reverse, plum tree in blossom by winding stream. Workmanship throughout of artistic order and is executed in gold, shakudo, red bronze and other metals, modelled in high relief. Signed by Shidskumi and dated 1800. 
75-TWO IRON SWORD GUARDS

(a) Screen, chrysanthemum and symbols, damascened in gold and silver. Signed by Seishin.

(b) Openwork screen design, finely inlaid with gold. Signature indistinct.

76-TWO GOROSA BRONZE SWORD GUARDS

(a) Wrestling match between the Niōs (two temple guardians), wrought in relief in gold, shakudo and red bronze. Signed by Masa-tsune Masatoshi.

From the Brayton Ives Collection, Catalogue No. 473.

(b) Deity in rocky cavern, waterfall and pine, in relief casting and incised and incrusted with gold and shakudo. By Shō-zu.

77-TWO IRON SWORD GUARDS

For short and long sword; concave shape. Dragon amid cloud forms and fire emblems chasing the Sacred Pearl, in relief casting and touched with gold and silver.

78-TWO GOROSA BRONZE SWORD GUARDS

(a) Shōki and demon, incised and inlaid with gold and silver. Signed, Otsu-riūken.

(b) Landscape, equestrian figure and attendant, wrought in relief and openwork. By Goto Mitsuatsa.

79-SKAKUDO SWORD GUARD

Two Niōs, wrought in bold relief in red bronze, gold and silver. Reverse, waterfall and birds, in silver and gold incrustation. Signed by Nao-masa (Yanagawa).

80-IRON SWORD GUARD

Surface in imitation of wood grains. Chicken, cock and vine in flower, skilfully wrought in relief, in gold, shakudo and shibuichi. Signed by Kiyo-mitsu.

81-GOROSA SWORD GUARD

Design of temple bell, with partial brocade covering; serpent modelled in high relief. By Hide-tomo. 
S2-IRON SWORD GUARD

Designed to represent worm-eaten wood. Serpent, modelled in shibuichi, coiling in and out. Signed by Hōshō.

\section{3-GOROSA BRONZE SWORD GUARD}

Genii on storm dragon, arising from the sea, in relief casting, chiselled and applied gold, silver and shakudo. By Konkwan (Iwamoto.)

\section{4-SHIBUICHI SWORD GUARD}

Seated figure and pigmies in flight, wrought in relief in silver, gold and shakudo. Reverse, bamboo grove by stream. Signed by Toshiyoshi.

85-TWO IRON SWORD GUARDS

(a) Garden gate, fence, willow tree and flowers in fine pierced work.

(b) Shape of demon, in openwork and relief casting; slight inlay of gold.

\section{6-SHIBUICHI SWORD GUARD}

Skilfully ornamented in red bronze, shakudo, gold and silver. On obverse, a bold figure of Niō, the temple guardian; on reverse, a temple post and a pilgrim and attendant. Signed by Shozui. 1750 .

From the Brayton Ives Coldection, Catalogue No. 519.

8\%-IRON SWORD GUARD

Deity on dragon rising from the sea, in relief casting in gold, silver and shakudo. Signed by Kuzui.

88-GOROSA BRONZE SWORD GUARD

Crane and water plants, skilfully wrought in relief in silver and gold. Reverse, fish nets and pine tree incised. Signed by Yoshinori.

89-GOROSA BRONZE SWORD GUARD

Coiled serpent, skilfully modelled and chiselled. By Ichiriū-ken Shujin. 
90-SWORD GUARD

Red bronze. Lotus buds and leaves, in gold and silver incrustation and incised. Signed by Kiukiushin. Designed after the celebrated painter Chinzan.

\section{1-TWO SHIBUICHI SWORD GUARDS}

(a) Figure of Daimio, noblemen and symbols, modelled in relief and incrusted with gold, silver and red bronze. Signature and seal of Miboku.

(b) Deer, rising sun, fungi and pine grove, wrought in relief and inlaid with gold. Signed by Tokuoki; designed after Okio.

92-GOROSA BRONZE SWORD GUARD

Cast in shape of Daikoku, "God of Wealth," from a design by

Motonobu. An exceedingly fine example of skilful metal-work by Hamano Noritsugu. 1780.

From the Brayton Ives Collection, Catalogue No. 522.

\section{3-TWO IRON SWORD GUARDS}

(a) Concave design. Dragon and key pattern, band incised and touched with gold. By Yeishun.

(b) Kiri crest and vines, inlaid with gold. By Koji, aged sixteen years.

94-GOROSA BRONZE SWORD GUARD

Elaborate ornamentation representing a monkey in flowing robes, holding a spy-glass, standing upon a rocky eminence by the seashore, and beckoning to wandering spirits of his race, who are seen in mystic clouds in the distance, and which are etched on the reverse. Signed by Morikuni Takanori.

95-IRON SWORD GUARD

Of soft finish. Japanese legendary subject, monster dragon and grotesque figures, finely modelled in high relief in various metals. By Masa-yoshi (Ishi-goru). 
96-IRON SWORD GUARD

Fisherman with large eel, and gourd vine in bearing, wrought in relief in shakudo, red bronze and gold. Signed by Nobu-masa.

97-GOROSA BRONZE SWORD GUARD

Daikoku (god of wealth) seated on his rice bags, finely wrought in relief and chiselled. Signed by Hamano Noritsugu, and dated 17\%0. Design after the painting of Motonobu.

98-IRON SWORD GUARD

Geese by stream and in flight, wrought in relief in gold and other metals. By Aki-yoshi.

99-SWORD GUARD

Obverse, of shakudo with an exquisite embellishment of quail, flowers and grasses in gold, silver and red bronze. Reverse, of silver, with butterfly, grasses and flowers in gold and red bronze. By Ishiguro Masayoshi. 1780.

From the Braytor Ives Collection, Catalogue No. 520.

100-GOROSA BRONZE SWORD GUARD

Japanese legendary subject: fox, bowl and child. Signed by Hidetomo. This subject is called by Japanese "Bunpuku chagama," or tea-kettle with badger.

101-IRON SWORD GUARD

Of soft finish. Stork in stream beneath willow, crow perched on stump, skilfully wrought in relief in gold, silver and shakudo. Signed by Toshi-tsugu. Nineteenth century.

102-IRON SWORD GUARD

Hermit, Daimio and full moon, wrought in relief in various metals. Reverse, "Crytomaria beyond the clouds." Signed by Bunkatsu. 
103-SOLID SILVER SWORD GUARD

Of elaborate workmanship. Two rampant horses in openwork. Signed by Takechika (Shiba), and dated 1800.

From the Brayton Ives Collection, Catalogue No. 529.

104-GOROSA BRONZE SWORD GUARD

Life-like serpent, skilfully wrought in bronze, shibuichi and gold. Signed by Hamano Chok-kwan.

105-SOLID SILVER SWORD GUARD

Elaborate openwork design in skilful workmanship. Eagle about

to capture a monkey hiding in a rocky cavern by the sea. Signed, Mori-chika (Hira-ish).

106-SWORD GUARD

Obverse, iron. A demon and his imp in a trial of strength, the demon wrought in high relief in red bronze and incrusted with gold. Reverse of gorosa bronze, with etched and gold inlaid decoration. Signed by Hirosada, of Mito.

From the Brayton Ives Collection, Catalogue No. 485.

107-RED BRONZE SWORD GUARD

Design of lotus leaf, bud and frogs, modelled in relief in gold and silver. An excellent example of art in metal work. Signed by Moto-toshi (Sei-shin-ken).

108-GOROSA BRONZE SWORD GUARD

Demon carrying off temple bell by lantern light, finely wrought in high relief in shibuichi, red bronze, shakudo and silver. Reverse, mountains and cascade. Signed by Chika-nori.

109-TWO IRON SWORD GUARDS

(a) Monkey on pine branch frightened by shadow cast by the moon on stream, wrought in high relief and inlaid with gold and red copper. Signed Hōyen.

(b) Lotus and storks by a winding stream, in relief casting and gold and silver incrustation. By Isshi. 
110-SHIBUICHI SWORD GUARD

Square shape. Carp, in relief in red bronze; plum in blossom, in relief casting and incrusted in gold. Reverse, moon reflected in stream. Signed by Mori-chika.

111-GOROSA BRONZE SWORD GUARD

Lotus in bloom and stork in flight, modelled in relief in gold, silver and enamel. Signed by Konkwan (Iwamoto).

112-GOROSA BRONZE SWORD GUARD

Pine tree and beetle, in relief in shibuichi, shakudo and gold. Signed by Miboku (Hamano).

113-SOLID SILVER SWORD GUARD

Group of butterflies, beautifully wrought in openwork and inlaid with gold, shakudo and enamel. An extraordinary example by Yoshi-zané.

The Following giant SWORD GUARDS WERE MADE For EXHIBITION PIECES AND NOT FOR UTILITY:

114-TWO BRONZE SWORD GUARDS

"Nō dancers," in relief in various metals. Signed by Kōhaku and Kō-taku.

115-TWO BRONZE SWORD GUARDS

(a) Sages making sake, in relief in red bronze, gold, silver and shakudo. By Soriūken; dated 1703.

(b) Bold figure of Niō, in red bronze, shakudo and gold. By Tenichi-moku, dated 1803.

116-TWO BRONZE SWORD GUARDS

(a) Children with performing monkcy, modelled in relief in various metals. By Masa-chika; dated 1743.

(b) Boy with hobby horse, in relief in shakudo and other metals. By Ujiyasu, of province of Awa. 
(a) "Nō dancers" in rich costumes, modelled in relief in gold, shakudo and other metals. By Yoshi-nari, dated 1769.

(b) Child laughing at priest, who is scratching his back with an ivory scratcher, modelled in relief in red bronze, shakudo and gold. By Aki-mori; dated $182 \%$.

\section{8-TWO BRONZE SWORD GUARDS}

(a) Deity in red bronze, shakudo and gold. By Mune-tomo; dated 1686.

(b) Sages tasting sake, modelled in relief, in silver, shakudo and other metals. Signed by Nao-tomo; dated 1819.

119-TWO BRONZE SWORD GUARDS

(a) Tug of war between God of Wisdom and warrior, modelled in relief in various metals. Signed by Toshio; dated $17 \% 3$.

(b) A royal falconer with falcon resting beneath pine tree, wrought in gold, silver and shakudo. Signed by Hisa-Kiyo; dated 1725 .

120-TWO BRONZE SWORD GUARDS

(a) Sake imp dancing, wrought in relief in silver, shakudo and gold. Signed by Kionashi.

(b) "Nō dancer" richly costumed, wrought in relief in red bronze, gold and silver. Signed by Kosei; dated 1758.

\section{1-TWO BRONZE SWORD GUARDS}

(a) Daikoku and mouse, wrought in relief in gold, shakudo and red bronze. Signed by Taka-fusa.

(b) Basket maker and servant, wrought in relief in various metals. Signed by Shō-hô; dated $17 \% 1$.

\section{2-TWO BRONZE SWORD GUARDS}

(a) Poet and Dog Foo, wrought in relicf in gold, silver and shakudo. Signed by Yoshi-hisa; dated 1705.

(b) Royal falconer and falcon resting beneath pine tree, wrought in relief in gold and shakudo. Signed by Muneyoshi. 
123-TWO BRONZE SWORD GUARDS

(a) Carver carving a huge mask, wrought in relief in red bronze, gold and shakudo. Signed by Masu-yuki; dated 1771.

(b) Japanese Pygmalion and Galatea, wrought in relief and various metals. Signed by Masa-nuki; dated 1755 .

124-TWO BRONZE SWORD GUARDS

(a) Fisherman humbling a nobleman, wrought in relief in gold, silver, shakudo and red bronze. Signed by San-ki; dated 1859.

(b) The musicians, modelled in relief in shakudo, gold and bronze. Signed by Tada-mitsu; dated 1803.

KNIFE HANDLES, SWORD MOUNTS AND COLLECTIONS OF EXTRAORDINARY SPECIMENS OF JAPANESE METAL WORK

125-SWORD GUARD FUCHI AND KASHIRA

Shibuichi. Ornamented to represent carved lacquer.

126-FUCHI AND KASHIRA

Two sets. Shakudo, ornamented with storks exquisitely wrought in relief and precious metals. Signed by Toshimitsu; dated 1845 .

127-FUCHI AND KASHIRA

Shibuichi. Peony and Dog Foo skilfully wrought in high relief and silver. Signed by Totan, of province of Dewa.

128-FUCHI AND KASHIRA

Five pieces. Shibuichi. Ornamentation representing the month of May celebration and Japanese laborers, wrought in high relief in various metals. Signed by Kuzui and Yoshi-chika.

129-KODSUKA AND KOGAI

Handles ornamented with cherry tree in blossom and torii, exquisitely wrought in silver and gold. Blade by Nobu-kuni, of Kaga.

Shakudo handle, with censer and flowers wrought in relief in precious metals. Blade by Tai-hei. 
(a) Iron handle, with symbols inlaid with enamels.

(b) Shibuichi handle; bamboo design with fish in relief in silver and shakudo. Blade by Yoshi-michi.

192-KNIFE HANDLE AND CHOP STICKS

Solid silver. Knife handle ornamented with dragon amid cloud forms carved in relief.

Chop sticks representing lightning and clouds. By Tokuoki.

133-THREE KNIFE HANDLES

(a) Shakudo, with lotus leaf and frog in metals and enamel.

(b) Silver; bamboo design, with inscription in relief.

(c) Shakudo and gold; implements in relief and in precious metal. Signed by Mitsuyoshi.

134-THREE KNIFE HANDLES

(a) Shakudo, with various crests and cloisonné enamel.

(b) Shibuichi, with deity in relief and gold.

(c) Bronze and shakudo. Dial inserted decoration representing Chinese astronomy and inscription on reverse. Signed by Fuki.

\section{5-THREE KNIFE HANDLES}

(a) Red bronze. Decoration, pearl diver escaping from dragon, finely wrought in relief in gold, silver and shakudo. Signed by Yoshi-akira.

(b) Gold and shakudo. Dog Foo in relief in gold. By Mitsumasa.

(c) Shibuichi, in imitation of wood. Decoration of demon, wrought in relief in red bronze and gold. By Nara Toshinaga.

\section{6-THREE KNIFE HANDLES}

(a) Shibuichi. Figure dignitary in relief in precious metals; reverse, inscription on gold panel. By Goto Ichijo.

(b) Shibuichi and gold. Japanese historical subjects, wrought in relief in precious metals. By Goto Yeijo.

(c) Shibuichi and gold. Falcon on pine branch, skilfully wrought in high relief by Mitsu-yoshi. 
(a) Shakudo, sharkskin surface. Horse in relief in gold.

(b) Red bronze, with sword in relief in gold and silver. By Goto Koshi.

(c) Shakudo and gold, with millet and grasses in relief in gold and red bronze. By Goto Sokujō.

(d) Red bronze and shakudo. Eel in relief and shibuichi. By Kochō (Kikuoka).

\section{8-FOURTEEN KNIFE HANDLES}

Shakudo and other metals, ornamented in relief in various designs in gold, silver and other metals.

\section{9-CABINET COLLECTION OF KNIFE HANDLES}

Fifteen rare specimens in a compartment case of lacquer and fabric.

(a) Shibuichi. Monkeys on pine tree reaching at reflection in stream, wrought in relief; by Yeizui (Riūchi-ken).

(b) Shibuichi. Fishes and grass wrought in relief in gold, silver and shakudo; by Juzui (Hamano).

(c) Yellow bronze. Figure of hermit, incised and carved; by Jo-i (Isshi).

(d) Shibuichi. Flowers, grass and insect in relief in gold, silver and shakudo; by Naga-Yoshi.

(e) Shakudo and gold. Lotus in bloom and kingfisher exquisitely wrought in high relief in various metals.

$(f)$ Shibuichi. Peony in relief in gold, silver and shakudo.

(g) Mottled bronze. Japanese boy with grotesque mask, wrought in relief in various metals.

(h) Iron. Wicker basket in relief casting and chiselled by Aki-toshi.

(i) Shakudo, with surface in imitation of wood. Fan and insect, in low relief in various metals; by Hiro-chika.

(j) Shakudo. Chrysanthemums and deer in relief in gold and other metals.

(k) Red bronze, with shakudo back. The long-legged and long-armed men in relief and incrusted with gold; by Riü-sets-ken.

(l) Shibuichi. Carp skilfully wrought and in high relief by Natsuo. Nineteenth century.

( $m$ ) Red bronze. Egg plants in high relief in shakudo and gold.

$(n)$ Shibuichi. Priest and disciple by winding stream; a legendary subject, wrought in relief and incised; by Ko-zui (Hamano).

(o) Shibuichi and silver. Grasshopper and full moon, wrought in relief and in gold; by Goto Renjo.

\section{0-A REMARKABLE COLLECTION OF KNIFE HANDLES}

Fifty extraordinary specimens, showing the perfection of Japanese skill in precious and other metals, each and every specimen being selected for its artistic treatment in design and workmanship. Fine lacquered cabinet. (See details on following pages.)

From the Brayton Ives Collection, Catalogue No. 543. 


\section{DETAILED DESCRIPTION OF \\ The Brayton Ives Collection of Knife Handles}

(1) Shibuichi and gold. Floral bouquet and Daimio boxes in relief in gold and shakudo; by Motohiro (Shokatei).

(2) Shibuichi. Geisha with mask, incised and incrusted with gold, silver and shakudo; by Kuzui (Hamano).

(3) Shibuichi. Mouse on handle of brush; reverse, incised figure of Daruma; by Yasuchika.

(4) Iron. Hut, with figure at window, looking at the moon emerging from a cloud.

(5) Shibuichi. Lotus leaf and pod, in relief in gold and other metals.

(6) Shibuichi. Fans floating on stream, inlaid with gold and shakudo.

(7) Shakudo. Kakemono, in gold and silver inlay.

(8) Shibuichi. Japanese artist painting portrait of female, carved and inlaid with gold; by Teru-chika (Hamano).

(9) Silver with shakudo back. Shaki and demon in gold, red bronze and shakude.

(10) Shibuichi. Hunter with dog on leash, in gold, red bronze and shakudo; by Chokuzui (Hamano).

(11) Shibuichi. Shaki punishing demon, carved and wrought in relief; by Katsu-bumi.

(12) Shibuichi. Warrior in gold, shakudo and other metals; by Sada-katsu.

(13) Shibuichi. Sake imp, standing on edge of sake jar, wrought in relief in gold, shakudo and red bronze; by Shōtō-sei.

(14) Shibuichi. Two figures in silver, gold and red bronze; by Kushū.

(15) Shakudo. Monkey frighten ${ }^{2}$ at snake, in relief in red bronze and gold; by Munenaga.

(16) Shibuichi. Ducks on stream, in which the moon is reflected by Haseo.

(17) Wood. Ornamented with gold lacquer; by To-unsai.

(18) Red bronze. Kwan-on seated on a rock, wrought in high relief in gold, silver and shakudo; by Masa-akira (a son of Miboku).

(19) Red bronze. Two priests, carved and inlaid; by Jo-i.

(20) Shibuichi. Figure and pine; legendary subject; in relief in gold, silver and other metals; by Somin.

(21) Shibuichi and yellow bronze. Japanese domestic scene, etched and inlaid with gold. Reverse, musical instrument in relief. Signed, Boyenken, aged 67 years.

(22) Silver. Figure of priest with incense burner. Mythological subject. Carved and wrought in relief by $\mathrm{K} \overline{0}$-gō; dated 1798 .

(23) Silver. Goose in stream, and grasses inlaid; by Jo-chiku.

(24) Gold, with shakudo panel. Spear of rice, in relief in gold; by Masa-tsune.

(25) Shakudo, with shibuichi back. Pheasant, plum in blossom, full moon, in relief in silver and gold. Reverse, sparrows on bamboo branch, etched by Kore-yoshi (Ishiguro).

(26) Gold, with shakudo panel. Various animals wrought in relief in gold; by Goto Mitsu-yuki.

(27) Shakudo, silver back. Mice in caricature, in relief and other metals. Signed by Hirotoshi.

(28) Shakudo. Figures of dignitaries, in relief in gold, silver, shakudo and red bronze; by Naga-ts'une. 
(29) Shibuichi. Cat watching butterflies, in red bronze and enamels; by Haru-yuki (Hirata).

(30) Shakudo. Shibuichi back. Golden dragon amid cloud forms. Reverse, tiger etched by Masayoshi.

(31) Shibuichi and gold monkey performing on a tight rope, in red bronze and gold; by Haruakira.

(32) Red bronze, with shakudo back. Wild goose in flight, silver moon and pine; by Moto-nori.

(33) Red bronze and shalkudo. Mount Fuji in enamel, and pine grove carved in relief; by Hirata Jurio.

(34) Shibuichi. Vine and butterflies, in gold and silver inlay.

(35) Red bronze, with shibuichi back. Puppy dogs playing with brocade ball, in relief and other metals; by Haruakira (Hogen).

(36) Shibuichi. Japanese artist, in relief in various metals; by Haru-chika.

(37) Shibuichi. Cock and hen in relief; by Toshi-yuki.

(38) Shibuichi. Fisherman and cuttle-fish, incised in relief.

(39) Shibuichi. Japanese lady holding branch of peach fruit. Carved and inlaid with precious metals by Nao-chika.

(40) Shakudo. Buddhistic priest standing under waterfall, from Japanese legendary subject.

(41) Shakudo with gold back. Pine branches in relief; by Nari-yoshi.

(42) Iron. Warrior and demons, in high relief in precious and other metals; by Yoshi-kiyo.

(43) Red bronze. Crayfish, in relief casting; by Masa-yoshi.

(44) Shibuichi. Bird on plum branch, in shakudo and red bronze. Signed, Sō Toshi-yoshi.

(45) Shakudo. Fan designs in relief and precious metals; by Katsu-toshi.

(46) Shibuichi. Jurojin; engraved and inlaid.

(47) Shibuichi. Boating party, in relief in gold, shakudo and red bronze. Reverse, ducks swimming; by Moto-taka.

(48) Shakudo. Bird on tile; by Yeigö (Goto).

(49) Shibuichi. Millet on straw mat, in gold and red bronze.

(50) Shakudo. Shaki punishing demon, in relief in gold and other metals.

141-A COLLECTION OF SWORD GUARD MOUNTINGS AND ORNAMENTS

A cabinet containing fifty specimens of sword guards, knife handles, mountings and ornaments for swords, finely wrought in various metals of artistic designs, gold and silver predominating in the ornamentation. The following artists are represented: Ichirin, Tomoyoshi, Kanehisa, Kamiyama Chidō, Goto Mitsumasa, Nara Haruchika, Hirotaka, Nara Shigemitsu, Harumitsu, Seimin, Toshimitsu, Yasuchika, Hosono Sozayemon, Sōten, Kimura Tomonaga, Nara Jo-i.

From the Brayton Ives Collectron, Catalogue No. 539.

\section{2-SWORD GUARDS, KNIFE HANDLES AND ORNAMENTS}

A collection of thirty-three specimens, mostly antique, in iron, and all of excellent workmanship and artistic designs. A number of 
the specimens are signed examples. Names are placed under each specimen inside of drawer. Mounted in a mulberry wood sectional cabinet.

From the Brayton Ives Collection, Catalogue No. 540.

\section{3-SWORD GUARDS AND MOUNTINGS}

A collection of forty-seven unusually fine specimens in gold, shibuichi, and other metals, all skilfully wrought and elaborately ornamented with relief and inlaid designs in precious and other metals. Mulberry-wood cabinet.

From the Brayton Ives Collection, Catalogue No. 538.

\section{4-A CABINET COLLECTION OF METAL WORK}

Thirty-five specimens of sword guards, knife handles, ornaments, and sword mounts. In shibuichi, iron and other metals, all showing fine workmanship in design and ornamentation, which is in precious and various other metals; sold with handsome cabinet and sword rack combined, of mulberry-wood, finely lacquered, and with bronze mountings.

From the Brayton Ives Collection, Catalogue No. 542.

\section{5-CABINET OF EXTRAORDINARY SPECIMENS OF METAL WORK}

One hundred and twenty sword guards, knife handles, kogais, sword ornaments and mountings, skilfully wrought in gold, silver, shibuichi, shakudo, iron and bronze. The following artists are represented by specimens of their best work: 'T'oshimasa, Shō-zui, Ichirin, Haruchika, Nagatsune, Shōami Katsuiye, Mitsuyoshi Yoshikani. Jo-i, Tobari Fukuzu, Koriusai Kazunori, Mitsuhiro, Toko Senjōnin, Yeisei, Ichijosai Hirotoshi, Iwamoto Konkwan, Masateru, Hamano Kuzui, Haruakira, Iwama, Masayoshi, Hamano Chokuyei, Kakujusai Katsutoshi, Tachibano-Noriyoshi, Otsuki Mitsuhiro, Konkwan, Kuzui, Shunwō-Hogen, Hirotoshi, Yasukazu, Toku, Kiyo-toshi, Masa-tsune, Akiyama Fuzuku, Mitsuyoshi, Teiken Toshihiro, Yasuchika, Hamano Kuzui, Gakushiu, Nobuyoshi, Hokio Kiyoshige, Mikami Yoshihide, 'Toshi-haru Masayoshi, Ikkaku, Moto-atsu, Tani Motosada, Nobuyoshi, Akimasa, Haruakira Hogen, Masayoshi, Kikuoka Mitsuyuki, Ko Hidetsugu, Sensai Tokuoki, Juwō, Katsumi Jochiku, Masateru, Shunkwan, Natsuo, Omori-Yeishu, Tokuoki, Masaakira, Yoshihide Tsunenao, Shigetaka, Masayoshi, Toshiyoshi, Nakagawa, Katsumi, Ishiguro,

Koreyoshi, Goto-Kokei, Omori Yeishū, Koriusai, Kazunori, Miboku Shozui, Nobuyoshi, Nomura and Masafusa. 


\section{SMALL OBJECTS IN GOLD, SILVER AND OTHER METAIS}

146-TWO GOLD OJIMES

(a) Hotei with sack. By Yoshichika.

(b) Figure of nobleman resting under a pine tree. Finely engraved by Shūraku.

From the Brayton Ives Collection, Catalogue No. 332.

\section{7-LARGE GOLD OJIME}

Exquisitely wrought in openwork. Insects, flowers and grasses. Signed by Mahiko.

From the Brayton Ives Collection, Catalogue No. 309.

\section{8-GOLD CLASP ORNAMENT}

Diamio lady and child, finely wrought. Signed by Mori-chika.

From the Brayton Ives Collection, Catalogue No. 308.

\section{9-PAIR GOLD ORNAMENTS}

Buddha and disciple, exquisitely wrought. Signed by Kuzui.

From the Brayton Ives Collection, Catalogue No. $31 \%$.

\section{0-PAIR GOLD ORNAMENTS}

Japanese god of wind and god of thunder, exquisitely wrought.

Signed by Nobuyoshi.

From the Brayton Ives Collection, Catalogue No. 312.

\section{1-GOLD ORNAMENT}

Eagle in flight; finely wrought.

152-TWO GOLD ORNAMENTS

Crayfishes.

153-PAIR GOLD ORNAMENTS

Buddha and disciple; exceedingly fine workmanship.

From the Brayton Ives Collection, Catalogue No. $31 \%$.

\section{4-PAIR GOLD ORNAMENTS}

Shaki pursuing demon who has stolen temple lantern.

From the Brayton Ives Collection, Catalogue No. 323. 
155-FOUR SWORD ORNAMENTS

Gilt bronze, dragon design.

156-SIX SWORD ORNAMENTS

Wrought in shakudo and silver. Figure and Japanese domestic subjects. By Otsuki Korin, aged 63 years.

15\%-FOUR SPECIMENS OF METAL WORK

(a) Ojime. Demon wrought in red bronze and gold.

(b) Dragon design in silver and shibuichi. By Ritsu-min.

(c) Shibuichi. Beetle in shibuichi, shakudo and gold.

(d) Miniature pilgrim bottle in shakudo and gold.

158-THIRTEEN SPECIMENS OF METAL WORK

Sword ornaments of various designs skilfully wrought in shakudo, shibuichi, red bronze and iron. By Y'eishū and Yoshikage.

159-TEN SPECIMENS OF METAL WORK

Miniature panels and small ornaments, finely wrought in shakudo, silver and gold.

160-POUCH ORNAMENT

Finely wrought in silver and other metals. Coral divers. By Mitsu-toshi.

161-TWO POUCH ORNAMENTS

(a) Bunch of flowers, wrought in silver bronze and incrusted in silver and malachite.

(b) Hyenas, in repoussé iron.

162-PAIR HIKITE

Shibuichi panels: figures of warriors wrought in high relief in various metals.

163-TWO POUCH ORNAMENTS

(a) Basket of flowers, finely wrought in shibuichi, shakudo and gold.

(b) Equestrian figure of warrior returning with trophies of war, wrought in shibuichi and other metals. By Moto-yoshi. 
164-FOUR ORNAMENTS

Skilful specimens of repoussé iron.

165-LARGE POUCH ORNAMENT

Branch of kiri leaves, wrought in bronze and inlaid with enamel.

166-FOUR NETSUKES

Button design, wrought in bronze and other metals. Pheasant design by Kazu-yoshi.

167-TWO PAIR OF POCKET CHOP STICKS

Wrought in silver and enamel.

168-TWO ANTIQUE LOCKS

Wrought in iron and inlaid with silver.

169-TWO SMALL OKIMONOS

(a) Wrought in bronze. Hotei, by Masa-toshi.

(b) Serpent on lotus.

17O-SMALL SILVER BOX

Relief ornamentation of warriors on lid.

171-JAPANESE SILVER SNUFF-BOX

"Mokume." Iron panel in lid, with exquisitely wrought ornamentation of floral and other designs in silver, gold and red bronze.

172-SMALL SILVER BOX

Relief ornamentation of warriors in various metals on lid.

173-SIXTEEN SPECIMENS OF METAL WORK

Insects and reptiles, finely reproduced in bronze and other metals.

174-SILVER COVER

Fine openwork design of flowers, grasses, insect and crescent.

ANTIQUE CHINESE BUCKLES AND JAPANESE

METAL-WORK PANELS

175-ANTIQUE CHINESE GIRDLE CLASP

Filigree gilt metal, with jade and glass ornaments inserted. 
176-ANTIQUE CHINESE GIRDLE CLASP

Gilt brass, with carved coral ornaments inserted.

17\%-ANTIQUE CHINESE GIRDLE CLASP

With carved lapis lazuli ornaments inserted.

178-ANTIQUE CHINESE GIRDLE CLASP

Gilt brass. Panel of white jade, of carved openwork design.

179-ANTIQUE CHINESE GIRDLE CLASP

Gilt brass. Centre panel of jadeite; carved border incrusted with coral, lapis lazuli and gold stone.

180-ANTIQUE CHINESE GIRDLE CLASP

Gilt brass; panel of white jade, with dragon and cloud forms carved in openwork.

181-ANTIQUE CHINESE GIRDLE CLASP

Gilt brass. Centre panel of mother-of-pearl, surrounded by coral and turquoise inserts.

182-ELABORATE ANTIQUE CHINESE GIRDLE CLASP

Gilt brass. Agate panels, surrounded by imitation brilliants.

183-ANTIQUE CHINESE GIRDLE CLASP

Gilt brass. Panel of white jade, with symbols and borders etched and carved in low relief.

184-COLLECTION OF ANTIQUE CHINESE GIRDLE BUCKLES

Eighteen specimens in gilt brass, jade, stone, glass and porcelain.

185-PRIEST'S MACE

Wrought in silver.

186-SET OF JAPANESE IRON PANELS

Nine specimens. Inlaid with floral designs in gold and silver.

187-SET OF JAPANESE PANELS FOR CABINET

Nine specimens of various shapes and sizes, finely wrought in repoussé copper; rich brown patina. 
188-SET OF EIGHT JAPANESE IRON PANELS

Diamond shape, ornamented with floral and vine designs in silver and gold inlay.

189-SET OF TEN JAPANESE IRON PANELS

Hexagonal shape. Hōwō bird, kiri, vine and floral designs, inlaid in gold and other metals.

190-SET OF TEN JAPANESE IRON PANELS

Double oval shape; floral designs inlaid with gold and silver.

191-LARGE COLLECTION OF JAPANESE MINIATURE PANELS

One hundred and fifty-five specimens, wrought in iron and inlaid with gold and silver. Various shapes and sizes.

\section{MISCELLANEOUS OBJECTS}

192-SPANISH BRIQUET

Iron. Elaborately and skilfully inlaid in gold and silver.

193-ROSE QUARTZ BEADS

Three specimens.

194-THREE SMALL SPECIMENS

Miniature seal box, damascened iron match box and carved stone netsuke.

195-NETSUKE

Design of mallet, wrought in shibuichi and silver.

196-THREE NETSUKES

Carved red lacquer, shell and box design.

197-FIVE NETSUKES

Carved wood; button and bird design.

198-THREE NETSUKES

Carved ivory; button and bead design. 
199-FOUR NETSUKES

Carved wood: Group of turtles, rice grinder, Daruma, grotesque figure.

200-THREE NETSUKES

Carved wood. Mask and mask boxes.

201-THREE NETSUKES

Carved wood. Seated figure, bat and Japanese potter.

202-FOUR WOOD NETSUKES

Badger, turtle, nut and pomegranate.

203-STRING OF BEADS

Coral, agate, amber and cloisonné.

204-NECKLACE

Carved nut shells and agate.

205-SAKE SAUCER

Tortoise-shell, decorated with gold lacquer.

206-ANTIQUE JAPANESE WATCH.

With netsuke and ojime.

20\%-JAPANESE PORTABLE WRITING CASE

Wave design wrought in silver.

208-JAPANESE PORTABLE WRITING CASE

Lotus design.

209-PORTABLE INK CABINET

Carved wood. Lotus design, with netsuke and ojime.

210-OKIMONO STAND

Carved ivory, openwork design.

211-LARGE PAPER CUTTER

Bamboo, finely carved; figures of priests and deities in low relief. 
Carved lily design. Teakwood stand.

213-CHINESE SECTIONAL BOX

The box is entirely veneered with the skin of the gourd fruit, then beautifully carved.

From the collection of the Chinese Minister, CHANG-YEN-Hoon.

\section{4-ANCIENT IVORY CARVING}

Representing Horus the child (or the younger), as distinct from Arœris, or Horus the elder, the god of pre-existence, who passes as the brother of Osiris and was worshipped at Letopolis. Was found by a native of Thebes in a small wood box in one of the large tombs at Draa-abou-el-Naghé.

215-PAIR JAPANESE GIRDLE ORNAMENTS

Carved bone, with silk tassels.

216-ANTIQUE CHINESE SILVER INCENSE BURNER

Ornamentation in relief casting. Teakwood stand.

217-ANTIQUE CHINESE FLINT POUCH

Mounted in silver and incrusted with lapis lazuli, coral and malachite.

\section{8-JAPANESE LADY'S TOILET BAG}

Solid needlework, with silver chain and bag; brass turtle netsuke, forming a box, and enamelled ojime.

219-JAPANESE SILVER TEAPOT

Hammered surface, with etched ornamentation of dragon and cloud forms.

220-TWO JAPANESE SHRINE ORNAMENTS

Gilded brass, and green enamels. 
Ch'ien-lung period. Ornamentation of Buddhistic symbols and scrolls, carved in high relief and partially gilt. Within is an image of Buddha's mother (Fo-mu), of gold and carved turquoise. An inscription on the back of shrine is in Chinese, Mongol, Manchu and Tibetan, of which the following is a translation: "Twentyseventh year of Ch'ien-lung, which is 1762 ; presented by the chief Llama, Awang-Panchuerk, to the Emperor Ch'ien-lung."

222-SMALL OVIFORM VASE

Silver and iron. Enamelled panels and silver and gold crests in relief.

Height, 41/2 inches.

223-JEWEL CASKET

East Indian. Wrought in steel and skilfully ornamented with gold damascene, and elaborate ornamentation of floral scrolls and palmettes.

Length, 81/2 inches; width, $51 / 2$ inches.

From the Welis Col.tection, London, May, 1883.

224-ANTIQUE EAST INDIAN GIRDLE

With Koran holder attached, skilfully wrought in silver. Flexible joints.

225-PAIR ALTAR INCENSE VASES

Of gilded brass, silver filigree and mother-of-pearl. The shell beautifully carved and partially touched with gold. From the centre of each rises a lotus, the petals in silver filigree, which open and close as the vase is taken from and put upon the altar.

226-ANTIQUE CASHMERE BRASS TRAY

Leaf shape. Engraved ornamentation filled in with white, black and red enamel.

Diameter, 151/2 inches.

227-TWO ORNAMENTAL PIECES

Two oblong plaques, with groups of life-like lizards, modelled in high relief.

228-THREE SMALL ORNAMENTS

Small Cashmere decorated gilded box; small silver gourd-shape vase and miniature statuette of gnome. Carved, petrified wood. 
CHINESE TEAKWOOD STANDS FOR VASES, BOWLS AND ORNAMENTS




246-SIX TEAKWOOD STANDS

247-THREE TEAKWOOD STANDS

248-FOUR TEAKWOOD STANDS

Assorted sizes.

249-FIVE TEAKWOOD STANDS

Assorted sizes.

250-SIX TEAKWOOD STANDS

Assorted sizes.

251-THREE TEAKWOOD STANDS

252-THREE CARVED WOOD STANDS

Various shapes and sizes.

253-SIX TEAKWOOD STANDS

Assorted sizes.

254-FOUR CARVED WOOD STANDS

For large bowls or jars.

255-FIVE TEAKWOOD STANDS

For bowls.

256--PAIR OF CARVED WOOD STANDS

25\%-THREE TEAKWOOD STANDS

Odd shapes.

258-THREE CARVED WOOD STANDS

259-THREE TEAKWOOD STANDS

Assorted sizes.

260-THREE TEAKWOOD STANDS

Assorted shapes and sizes.

261-THREE TEAKWOOD STANDS

Odd shapes. 
262-THREE TEAKWOOD STANDS

Odd shapes.

263-THREE TEAKWOOD STANDS

Odd shapes.

264-SIX TEAKWOOD STANDS

Assorted sizes.

265-SIX CARVED WOOD STANDS

Assorted sizes.

266-FOUR CARVED WOOD STANDS

267-FOUR CARVED WOOD STANDS

Assorted sizes.

268-THREE TEAKWOOD STANDS

269-THREE TEAKWOOD STANDS

Odd shapes.

2\%O-FOUR CARVED WOOD STANDS

Assorted shapes and sizes.

E'1-SIX TEAKWOOD STANDS

Assorted shapes and sizes.

272-TWO TEAKWOOD STANDS

273-TWO TEAKWOOD STANDS

274-TWO TEAKWOOD STANDS

Odd shapes. 


\title{
SECOND AFTERNOON'S SALE
}

THURSDAY, JANUARY 18Th, 1906

\author{
AT THE AMERICAN ART GALLERIES \\ BEGINNING AT 2.30 o'CLOCK
}

\section{JAPANESE AND EUROPEAN CARVINGS, NE'TSUKES, GROUPS AND HISTORICAL SUBJECTS}

275-THREE NETSUKES

(a) Boy acrobats.

(b) String of old coins. By Mitsuhiro.

(c) Boy with mask and Daruma. By Toshimasa.

2'6-TWO NETSUKES

Masks. One by Shugetsu.

277-THREE NETSUKES

(a) Two turtles. By Masakazu.

(b) Flies on an old stump. By Shibayama.

(c) Mouse. By Ikkan.

278-TWO NETSUKES

(a) Boy carrying large rice boiler.

(b) An octopus.

279-MINIATURE SCREEN

Old Chinese. Carved inscriptions.

280-TIIREE NETSUKES

(a) Making rice cakes. By Shuzen.

(b) Woman with mask. By Itsumin.

(c) Warrior on wild boar. By Shuraku. 
2S1-TWO NETSUKES

(a) Mask of Tengu. By Ichiruku.

(b) Group of masks. By Toyokazu.

282-TWO NETSUKES

(a) Coiled snake. By Toyokazu.

(b) Mouse on beans.

283-TWO NETSUKES

(a) Double masks.

(b) Mouse and walnut.

284-TWO NETSUKES

(a) Shaki looking down a well. By Kigioku.

(b) Acrobat.

285-TWO NETSUKES

(a) Group of cows. By Tomochika.

(b) Mermaid on shell. By Tomokazu.

286-TWO NETSUKES

(a) Enraged demon. By Sui-u.

(b) Monkey in New Year's costume.

2SY-TWO NETSUKES

(a) Cock and hen on a tile. By Masanao.

(b) Group of mice. By Masateru.

288-TWO NETSUKES

(a) Group of masks.

(b) Group of turtles. By Tadakazu.

289-TWO NETSUKES

(a) Shōki punishing demon. By Sho-ko.

(b) Monkeys with gourd. By Masa-chika.

290-TWO NETSUKES

(a) Group of turtles. By Tadamasa.

(b) Demon and Benten. By Tomochika and Chikahiro. 
291-TWO NETSUKES

(a) Boys carrying a treasure-bag. By Kario.

(b) Farmer smoking. By Shuzan.

232-MINIATURE OKIMONO

Turtle. By Kaigiokusai.

293-TWO NETSUKES

(a) Pine cone, which opens and shows the long-lived couple under a pine tree. By Keizan.

(b) Mice in melon. By Sozen.

294-SMALL CARVING

Shōki in jinrikisha, pulled by a demon.

295-TWO SMALL CARVINGS

(a) Wrestlers. By Itsumin.

(b) Acrobats performing.

296-WOOD CARVING

Fish on lotus leaf.

297-WOOD CARVING

Group of mice and bean vine.

298-WOOD CARVING

Coiled snake. By Minko.

299-WOOD CARVING

Fighting sparrows.

S00-PAIR STATUETTES

Carved in wood and lacquered. Niō. By Koun.

Height, 4 inches.

301-WOOD CARVING

Turtles. By Tadakazu.

Height, 4 inches.

302-STATUETTE

Carved wood and lacquered. Priest and dragon. Seventeenth century. 


\section{SO3-WOOD CARVING}

Two toads. By Shunko.

\section{SO4-WOOD CARVING}

Genii on carp; Chinese legend. By Kogioku.

305-IVOOD CARVING

Hawk perched on bough, with serpent in claws. By Shunko.

306-WOOD CARVING

Life-like toad. By Tadahao.

30\%-THREE FIGURES

Carved wood. Demon musicians.

308-CHINESE WOOD CARVING

Buddha's hand fruit.

309-JAPANESE WOOD CARVING

Turtle on rock. By Shoko.

310-WOOD CARVING

Old Japanese woman resting by the wayside.

S11-WOOD CARVING

Bird on lotus pod.

Height, 4 inches.

312-PERFUME BOX

Carved bamboo. Floral and archaic designs in fine relief carving.

Old Chinese specimen.

313-SET OF TEN WOOD CARVINGS

Ceremonial gathering of priests and disciples.

314-FOUR IVORY NETSUKES

(a) Monkey with ball.

(b) Young artist.

(c) Genii on carp.

(d) God of wisdom. 
S15-SIX IVORY NETSURES

(a) Man shaving.

(b) Woman with sake jar.

(c) Boy with crane.

(d) Boy with treasure-bag. By Giokuyosai.

(e) Rat. By Ran-itsu.

(f) Boy with gourd.

S16-FOUR IVORY NETSUKES

(a) Woman and child with grotesque mask.

(b) Boy with gourd.

(c) Boy with crane.

(d) Boy with mask.

317-THREE IVORY NETSUKES

(a) Octopus.

(b) Creeping child. By Masakatsu.

(c) Puppy dog on a writing case. By Norishige.

318-FOUR IVORY NETSUKES

(a) Badger with wind drum.

(b) Badger caricaturing a priest.

(c) Genii and toad.

(d) Mermaid.

319-THREE IVORY NETSUKES

(a) Fabulous animal on seal.

(b) Elephant on seal.

(c) Dog Foo and peony flower.

320-TWO IVORY NETSURES

(a) Group of animals; signs of Zodiac intricately carved.

(b) Dried fish.

321-THREE IVORY NETSUKES

(a) Mask. By Kiō-min.

(b) Button with metal-work panel.

(c) Button with carved ivory panel. 
S22-TWO IVORY NETSUKES

(a) Dog Foo on a seal.

(b) Two demons being stoned; one hiding beneath a large straw hat.

323-TWO IVORY NETSUKES

(a) Boy wrestlers. By Nao-mitsu.

(b) Fox disguised as a priest.

324-TWO IVORY NETSUKES

(a) Group of animals and reptiles. Signs of the Zodiac in openwork carving. By Tomochika.

(b) Group of fishes.

S25-TWO IVORY NETSUKES

(a) Monkey and vine on seal.

(b) Child with bucket. By Riū-min.

326-TWO IVORY NETSUKES

(a) Fisherman caught by an octopus. By Zugioku.

(b) The Goddess of Heaven. By Gioku-hō.

327-TWO IVORY NETSUKES

Masks.

328-TWO IVORY NETSUKES

(a) Two mice. By Kō-kei.

(b) Monkey with pomegranate.

329-TWO IVORY NETSUKES

(a) A demon grinding rice.

(b) Palace of the sea supported by the guardian dragon. By Kage-toshi.

S30-THREE IVORY NETSUKES

(a) Monkey frightened at a mask. By Tomo-kazu.

(b) An ear of corn.

(c) Dragon amid sea foam.

SS1-TWO IVORY NETSUKES

(a) Group of nine masks.

(b) Head of a decapitated Aino. 
332-TWO IVORY NETSUKES

(a) Young boar on a bed of leaves.

(b) Boy with giant mask.

333-TWO IVORY NETSUKES

(a) Japanese legendary subject: stealing the temple bell.

(b) Laborer trying to lift a large stone.

334-TWO IVORY NETSUKES

(a) Mice attacking a young Tengu emerging from its shell. By Ikkō.

(b) Carved button; child with dog. By Chōunsai.

335-TWO IVORY NETSUKES

(a) A horse resting. By Giokuyosai.

(b) Monkeys attacked by an octopus.

336-TWO IVORY NETSUKES

(a) Kylins playing with a brocade ball. By Giokuyosai.

(b) Lizard on a fragment of tile.

38\%-TWO IVORY NETSUKES

(a) Dog Foo holding in his mouth a peony. By Tonnō.

(b) Deer sheltered under a pine tree.

338-TWO IVORY NETSUKES

(a) Snake on a straw hat under which a frog has taken refuge.

By Nao-mitsu.

(b) A runaway horse. By Haku-un.

399-TWO IVORY NETSUKES

(a) Monkey with large carp on a shell, under which is concealed an octopus.

(b) Koi fish, shell and crab on a dish.

340-TWO IVORY NETSUKES

(a) Child on bundle, from holes in which Hotei and boy are peeping.

(b) Monkey in the toils of an octopus. By Kiku-shige. 
341-TWO IVORY NETSUKES

(a) Group of twelve masks.

(b) Hotei and children playing with a mask. By Giokuyosai.

\section{2-IVORY NETSUKE}

Group of nine masks.

\section{3-IVORY NETSUKE}

Basket of fruit exquisitely carved. By Sawa-Kihō.

\section{4-TWO IVORY NETSUKES}

(a) Group of fish.

(b) Monkey on piece of cuttle-fish. By Hide-masa.

\section{5-TWO IVORY NETSUKES}

(a) An enchanted octopus.

(b) Insects on a stump.

\section{6-TWO IVORY NETSURES}

(a) A tea jar carved in relief with mountain scenery. By Ikkō.

(b) Group of deer. By Masa-mine.

\section{7-IVORY NETSUKE}

A warrior in cart being drawn by his retinue. By Masa-tsugu.

\section{8-IVORY NETSUKE}

Basket of fish. By Nōkō.

\section{9-IVORY NETSUKE}

Sacred elephant, with trappings incrusted with mother-of-pearl, coral and turquoise. By Masa-haru.

350-TWO IVORY NETSUKES

(a) Fabulous animal.

(b) A wandering pilgrim.

351-TWO IVORY NETSUKES

(a) Genii on a carp.

(b) A mythical animal. 
352-IVORY NETSUKE

A happy philosopher with his toad.

353-IVORY NETSUKE

Water nymphs charming an octopus: By Shū-raku.

354-IVORY NETSUKE

Group of fish.

355-IVORY OKIMONO

Chicken in cage on an old straw mat, and rooster outside watching. Specimen of intricate carving. By Kwaigioksai.

356-SMALL IVORY CARVING

Gourd-shape box; within, a minute carving of a horse on a stirrup.

35\%-TWO SMALL IVORY CARVINGS

(a) Making sake. By Giokushū.

(b) A Samurai.

858-TWO SMALL IVORY CARVINGS

(a) A performing monkey.

(b) A hunter.

359-TWO IVORY CARVINGS

A cat and kitten caricaturing Geisha girls.

360-JAPANESE IVORY CARVING.

Warrior, female and Tengu. Signed by Kiō-min.

Height, 21/2 inches.

361-IVORY CARVING

Laborer frightened by a mouse. By Masa-nori.

362-IVORY CARVING

Monkeys climbing on a deer. By Rei-yō.

363-IVORY CARVING

Sake imp playing with the turtle of longevity. By Toshimune. 
354-IVORY CARVING

Street musicians.

365-IVORY CARVING

A skull, lotus and toad.

366-IVORY CARVING

A monkey admiring a netsuke attached to an inro.

367-IVORY CARVING

A tug of war between monkey and skeleton.

368-IVORY CARVING

A ceremonial gathering of Buddhist priests and their disciples: a group of nine minute figures. By Giokushiusai.

369-JAPANESE IVORY CARVING

Shōki hiding from a demon. Signed by Kiōkū-Shinsai.

Height, $3 \frac{1}{2}$ inches.

370-IVORY CARVINGS

Four netsukes. Ivory button shape; carved, incrusted and lacquered.

371-IVORY OKIMONO

A warrior astride a tiger. By Ono Toshitsugu.

372-IVORY GROUP

A spirited combat between a mounted warrior and foot soldiers.

By Masa-nobu.

373-IVORY GROUP

A Buddhistic ceremonial gathering. By Giokuyosai.

374-IVORY GROUP

Three blind men quarrelling.

375-IVORY GROUP

"The Three Guardsmen." By Shunrō. 
376-IVORY CARVING

A philosopher resting by the roadside.

SyY-IVORY CARVING

Skeleton, monkey and toads.

378-IVORY CARVING

Boy with young monkey on his back, standing on a toad, a frog holding on to the leg of the monkey.

379-IVORY STAND

Carved and tinted in imitation of malachite.

Height, 3 inches.

380-IVORY STAND

Carved openwork design of peach branches, and tinted green.

381-SMALL IVORY TRAY

Decorated with gold lacquer.

382-IVORY OKIMONO

Group of three figures: a Japanese poet receiving two pilgrims.

Signed by Shunsei. Mounted on a carved teak stand.

383-JAPANESE IVORY CARVING

Long-legged and long-armed men in the toils of an octopus.

Height, $3 \frac{1}{2}$ inches.

384-JAPANESE IVORY CARVING

A combat between Ushiwaka and Benkei. Japanese historical subject.

Height, 4.1/2 inches.

385-JAPANESE IVORY CARVING

An arrow-maker. By Sei-wa.

Height, 21/4 inches; length, 31/2 inches.

386-JAPANESE IVORY CARVING

An old woman breaking cones from pine branches. Signed by Sei-ko. 
387-WOOD CARVING

Kwan-on on floating lotus.

Height, 51/2 inches.

388-SET OF EIGHT MINIATURE FIGURES

Buddhist priests and their disciples.

389-WOOD CARVING

Japanese woman trying to conceal her lover.

Height, 7 inches.

390-JAPANESE WOOD CARVING

One of the Rakans and his disciples. By Hobai.

Height, 7 inches.

391-TWO WOOD CARVINGS

By Kanzan and Zietto-ku. Seventeenth century.

392-CARVED WOOD VASE

Stump of pine tree. Old Chinese specimen.

Height, 5 inches.

393-WOOD CARVING

Seated figure of a priest. Very old and fine specimen. Pottery base.

394-WOOD CARVING

Height, $7 \frac{1}{2}$ inches.

Representing Japanese warrior Tawara-toda Hidesato trying to reach the sea palace. Carved by Harunobu, and signed.

395-WOOD CARVING

Kwan-on watching a suffering demon. A fine specimen. Signed by Riūgando.

396-WOOD CARVING

A Shinto priest catching a temple oil-man who has committed a theft.

Height, 71/4 inches.

39\%-EIGHT CARVED IVORY ORNAMENTS

Chinese design known as "Buddha's hand fruit."

398-JAPANESE IVORY CARVING

Group of three figures: Deity, Daimio and attendant. By Masahiro.

Height, 4 inches. 
399-IVORY CARVING

Monkeys endeavoring to cut up a mammoth melon. By Iyekazu.

400-JAPANESE IVORY CARVING

Group of three mice.

Height, 11/2 inches.

401-JAPANESE IVORY CARVING

Skull, group of toads and serpents.

Height, 23/4 inches.

402-JAPANESE IVORY CARVING

"The Dance of Death." Skeleton, female musician and imp drinking sake.

Height, $3 \frac{1}{4}$ inches.

403-PAIR WOOD CARVINGS

Seated figures of Kwan-on and Amida, decorated with gold lacquer. Height, 51/2 inches.

404-IVORY CARVING

A wood-gatherer splitting faggots. By Seigâ.

405-TWO IVORY STANDS

Carved in openwork and tinted. Old Chinese.

406-LARGE IVORY BOX

Representing a bamboo wicker basket filled with shells.

Height, 6 inches; length, 6 inches.

407-FINE JAPANESE IVORY GROUP

Laborer and son, and fisherwoman with basket of shellfish. Signed

by Riusui. Nineteenth century. Mounted on a teakwood stand. Height, 61/2 inches; length, 7 inches.

408-JAPANESE IVORY CARVING

Group of rats and mice. By Kazu-Mitsu.

409-IVORY NETSUKE

Button design. Figures of demons carved in high relief. Signed by Kogiokusai. 
410-JAPANESE IVORY SWORD GUARD

Exquisitely ornamented with mother-of-pearl, tortoise-shell and coral inlays. Signed by Shiba-Yama.

\section{1-JAPANESE IVORY CARVING}

Figure with koi fish. By Toshiu-muné.

\section{2-JAPANESE CARVED IVORY GROUP}

Seated figure of a deity "Queen of Heaven" and figure of boy attendant placing incense in koro. The whole mounted on a rosewood stand carved to represent rocks. An unusually fine specimen of skilful carving by Toshi-tsugu. Has finely lacquered extra stand.

$$
\text { Height, } 6 \text { inches; length, } 9 \text { inches. }
$$

413-LARGE IVORY STAND

Oblong. Carved openwork border. Old Chinese.

Height, 2 inches; length, 13 inches.

414-OKIMONO

Ivory crayfish. Articulated. Seal mark, Sō.

\section{5-OKIMONO}

Shōki punishing a demon. Figure of Shōki finely decorated with lacquer, and has an ivory face and hands; the demon of carved ivory. On teakwood stand.

$$
\text { Height, 81/2 inches. }
$$

\section{6-JAPANESE IVORY CARVING}

Fisherman frightened at a monster spider climbing out of a winkle shell. Signed by Masa-nobu.

\section{1\%-FINE JAPANESE IVORY CARTING}

Historical subject. Benki, one of the most famous Japanese warriors, especially celebrated for his great strength, having conceived a desire for the bell of the temple, takes it from the belfry and unaided carries it to the top of the hill on which he resides. Other warriors, in great astonishment, gather round admiring the wonderiul feat. Signed by Masuyoshi. Carved teakwood stand. 
Elaborate ornamentation, of equestrian figure of warrior and attendants, pine tree, rocks and landscape. Skilfully carved in high relief and undercut. Signed by Gioku Shinsai. Mounted on a finely lacquered revolving stand.

Height of tusk, 121/2 inches; diameter, 51/4 inches.

\section{9-IMPORTANT JAPANESE IVORY FIGURE}

Statuette of a genii, holding aloft in his right hand a crystal ball symbolical of the Sacred Pearl, and in his right hand a censer from which is emerging a bold dragon amid fire emblems. The figure is artistically carved and richly embellished with gold lacquer. Mounted on a beautiful stand of lotus design, carved in openwork and finished in gold lacquer and incrusted with ivory.

Height of figure, 12 inches; height of stand, $9 \frac{1}{2}$ inches.

\section{0-AN IMPORTANT JAPANESE IVORY GROUP}

Consisting of five finely carved figures and accessories in lacquer and silver. The group represents an ancient Chinese historical subject. The standing figure, Gantok, became emperor; the figure on the right is Kaugeroo, who was deified by the Chinese and became God of Fortune; the one on the left is Chohie; the two small figures are their attendants. The scene is laid in a peach garden in summer, where, after the banquet, the warriors swore eternal brotherhood to live and die together. The period is about 9501000 A.D. By Nobu-yuki. Mounted on a handsome rosewood stand, which is richly decorated with gold lacquer and incrusted with mother-of-pearl and ivory.

\section{1-LARGE IVORY TUSK VASE}

Ornamented with artistically carved male and female figures and a two-horned dragon, illustrating a Japanese mythological subject. The costumes and accessory of figures beautifully etched and tinted with enamel colors. An extraordinary example. By Somin, and signed. Carved wood base, in imitation of a tree trunk, with fungi of carved ivory in relief. 
4R2-IMPORTANT JAPANESE IVORY GROUP

Figure of the goddess Bentin, supported by a two-horned dragon, and a figure of a warrior. Japanese mythological subject. Mounted on a wood stand carved to represent rocks. Signed by Masa-nobu.

Height, 12 inches; length, 13 inches.

423-JAPANESE IVORY CARVING

A man reclining on a bamboo settee, a pipe in his nand and a smoker's outfit by his side; his head is movable. Signed: Toshiumuné.

Length, 41/2 inches; height, $21 / 2$ inches.

424-JAPANESE IVORY FLAT CARVING

Deer and doe. Skilfully carved and tinted in natural colors.

Length, 31/2 inches.

425-SET OF IVORY CHESSMEN

Carved ivory of intricate workmanship. Chinese. (Incomplete.)

426-WOOD CARVING

A genii with gourds. Carved and lacquered ornamentation. Seventeenth century specimen. Has stand.

Height, 111/2 inches.

427-WOOD CARVINGS

Chinese warrior $\mathbf{K} w a n u ̈$ and his attendant. Finely carved and lacquered with gold. On teakwood stand.

Height, 61/2 inches.

428-WOOD CARVING

Group of three life-like turtles. Signed by Sō-ü. Eighteenth century.

429-WOOD CARVING

Buddhist disciple riding on a lion. Finely carved and painted with gold lacquer and tinted in colors. Chinese specimen of seventeenth century.

Total height, 16 inches.

430-OKIMONO

Niō carved in wood. Japanese merchant and his son carved in ivory. The father and son gazing at the giant Nio with a look of surprise. Teak stand. 
$431-O K I M O N O$

Hotei and children, carved and enamelled.

Height, 9 inches.

432-OKIMONO

Life-size cat. Finely carved in wood and coated with a white enamel. By Komei.

\section{EUROPEAN CARVINGS}

433-FOUR IVORY STATUETTES

"Cupid Practising Archery," and "Cupid Captive."

434-FIVE IVORY STATUETTES

"Cupid Forging a Heart," and kindred subjects.

435-IVORY.CARVING

Two oxen drawing a cart, in which are two seated figures.

436-MINIATURE STATUETTE

"St. Barbara" holding sword and branch. At her right is a chalice resting on a cloud and surrounded by rays of light.

437-IVORY BAS-RELIEF

Half length figure of Christ bearing a reed. Signed, J. P. H. Height, 3 inches; width, 21/4 inches.

\section{8-OVAL IVORY MINIATURE PORTRAIT}

Head and bust of a French ecclesiastic finely carved in relief.

Framed in black wood and gilt metal. Seventeenth century.

489-PAIR IVORY BAS-RELIEF PORTRAITS

Francis I and his Queen. Artistic productions.

Height, 3 inches; width, 21/2 inches.

440-IVORY BAS-RELIEF

"Silenus." Artistically carved specimen.

Length, 71/2 inches; width, 3 inches.

441-EUROPEAN IVORY CARVING

Nude figure of a child lying down, with right hand pointing to

the forehead. German workmanship of the eighteenth century. 


\section{2-IVORY BAS-RELIEF}

A reclining satyr and infant bacchanals, five in number, playing with a goat, all carved in high relief. By François Duquesnoy, called François Flamand. Of the seventeenth century. Framed in bronze and ormolu.

Height, 8 inches; length, 13 inches.

\section{3-EUROPEAN IVORY CARVING}

Horse attacked by wolves.

Height, 7 inches; width, 6 inches.

\section{4-EUROPEAN IVORY CARVING}

Mounted Amazon in combat with a lion. Copied from the group by Kiss in front of the Berlin Museum.

Height, 5 inches; length, 6 inches.

445-EUROPEAN IVORY CARVING

An Amazon.

Height, 6 inches; length, 51/2 inches.

446-EUROPEAN IVORY CARVING

"Angel of Peace."

Height, 101/2 inches.

\section{7-EUROPEAN IVORY CARVING}

"Venus and Cupid." Nude female figure with wrist bound by a chain of flowers and held by a cupid.

Height, 9 inches.

\section{8-RENAISSANCE CASKET}

Wrought in silver and ornamented with skilfully carved ivory bas-reliefs depicting numerous hunting scenes. The ornaments and borders are of renaissance scroll design with masks intervening. Round the base is a border of oak leaves and acorns, and corner ornaments of eagle griffins. Late sixteenth or early seventeenth century.

Length, 12 inches; width, 8 inches.

449-FOUR IVORY STATUETTES

"Cupid Begging," "Cupid Unmasked," and kindred subjects.

450-IVORY GROUP

Seated female figure veiled, holding her garment over a sleeping boy; at her left stands a cupid peeping at the sleeping figure.

Mounted on an ivory pedestal. From Nuremberg. 
451-CARVED IVORY GROUP

"Lohengrin and Elsa." From Nuremberg.

Height, 6\% inches.

452--IVORY BAS-RELIEF

"Laughing Man." After Teniers. Finely carved in high relief. Height, 6 inches; width; 41/2 inches.

453-CARVED BAS-RELIEF

Woman with pet dog. Finely carved in high relief.

Height, 6 inches; width, $4 \frac{1}{2}$ inches.

454-IVORY BAS-RELIEF

Bust portrait of a man. Finely carved in high relief.

Height, 6 inches; width, $4 \frac{1}{2}$ inches.

455-IVORY CARVING

Woodland and minute figures of a group of gypsies and animals in intricate workmanship. Background of mother-of-pearl; framed in ivory of openwork lily design, under glass.

Length, $7 \frac{3}{4}$ inches; height, $6 \% / 8$ inches.

456-IVORY BAS-RELIEF

"Antinöus." Copy from the antique in Rome. Finely carved in high relief.

$$
\text { Height, 5\%/8 inches; width, 41/2 inches. }
$$

45\%-IVORY CARVING

"A Stag Hunt." Illustrated by minute figures intricately and skilfully carved. Painted background. Mounted in an oval frame under glass.

Height, 81/4 inches; length, 9 inches.

458-EUROPEAN IVORY STATUETTE

"Bacchante." Black wood pedestal. From Nuremberg.

Height, 91/2 inches.

459-EUROPEAN IVORY CARVING

Cupid issuing from an egg-shell, which rests on a supporting pedestal, with roses and other flowers carved in high relief. On one of these rests a butterfly, with projecting, half-opened wings. An unusually fine specimen of skilful carving. By A. Drelst, Drcchsler, Munich, 1883.

Height, $9 \frac{1}{2}$ inches.

460-ANTIQUE SHORT SWORD

Hilt and mountings of skilfully carved ivory. Scabbard covered with red velvet.

From the collection of the late Prince Rudolph, Vienna, 1889. 
461-IVORY HUNTING HORN

Elaborate and artistic ornamentation carved in high relief. Wild

boar and deer hunting scenes, a vignette portrait of the Emperor

Francis Joseph and coat of arms.

Length, 29 inches.

From the collection of the late Prince Rudolph, Vienna, 1889.

462-ANTIQUE SWORD

Ivory hilt and scabbard of artistic and intricate carving of hunting scenes, foliations and other designs.

Length, 361/2 inches.

From the collection of the late Prince Rudolph, Vienna, 1889.

463-LARGE IVORY TANKARD

The carving, which is skilfully executed and in very high relief, depicts a procession of equestrian and other figures illustrating an historical event. The cover is surmounted by an equestrian figure of a royal personage, and a page in attendance. Mountings in repoussé silver gilt.

Height, 191/2 inches; diameter, 7 inches.

From the collection of the late Prince Rudolph, Vienna, 1889.

464-GRAND SILVER GILT AND IVORY PLAQUE

'The plaque of fine repoussé and chiselled workmanship. In the centre is an artistically carved ivory bas-relief, illustrating an ancient banquet scene, surrounding which, inlaid in the border, are six panels of allegorical subjects most delicately and wonderfully executed in relief carving.

Length, 28 inches; width, 22 inches.

From the collection of the late Prince Rudolph, Vienna, 1889.

465-ST. MICHAEL AND THE POWERS OF EVIL

An extraordinary ivory group, representing St. Michael in combat with the powers of evil. The angel, with extended wings, holding aloft a long wand, tramples under foot a monster in human form, thrusting him headlong downward, together with a serpent partly entwined around him. On the lower part of the base, which is in carved wood and ormolu, representing rocks with curling tongues of flame, is a third figure in human shape writhing in the tortures of fire, and opposite him is a, winged dragon emerging, salamander-like, from the flames. Italian, of the seventeenth. century, in the style of Bernini.

Height, 361/2 inches; width, 211/2 inches. 


\section{IVORY VASE AND ORNAMENT STANDS}

465a-THREE CARVED IVORY STANDS

Circular shapes for vases.

465b-THREE CARVED IVORY STANDS

Assorted circular shapes for vases.

465c-THREE CARVED IVORY STANDS

For ornaments. Wave and floral designs; two of green tint.

465d-THREE CARVED IVORY STANDS

For ornaments and disk. Lotus leaf and archaic designs carved in openwork.

4E5E-THREE CARVED IVORY STANDS

Carved in openwork. Leaf and lily design.

465F-FIVE CARVED IVORY STANDS

Circular shapes. White, purple, green, blue and amber tints.

465g-TWO IVORY STANDS

Carved in openwork. Cloud forms and foliated designs.

465h-TWO STANDS

One carved ivory; the other carved stone.

465i-TWO ORNAMENT STANDS

Carved ivory of openwork design on teakwood bases.

465j-TWO LARGE IVORY STANDS

Carved in openwork, pine and fungi.

465k-TWO LARGE IVORY STANDS

Finely carved in openwork. Fungi and bamboo branches, leaves and blossom tinted in green. 
465L-LARGE IVORY STAND

Lotus and rocks. Carved in openwork.

465m-COVER AND TWO STANDS

Carved ivory and tinted in green.

465n-CARVED IVORY STAND

Pine branches and cloud forms in openwork.

\section{MISCELLANEOUS CHINESE AND JAPANESE OBJECTS}

466-JEWEL BOX

Made of Japanese wood called "binroji." Decoration on top of the cover represents a vine with leaves of gold, enamel and bronze, incrusted in relief.

Height, 13/4 inches.

467-TORTOISE-SHELL BOX

Chinese. Most intricate carving of Chinese garden scenes, houses and figures.

Diameter, 41/4 inches.

468-THREE MINIATURE MASKS

Two of them signed "Matsugoro, aged sixty-one years." Date, eighteenth century.

469-COLLECTION OF OLD MINIATURE MASKS

Box in two sections, containing eighteen masks, some of them bearing signatures of Deme Uman, Masayuki, Shūmin, Shūkoku and

Riūgioku. Dates, sixteenth century to eighteenth century.

470-SMALL TEMPLE ORNAMENT

Lotus leaf supported by two priests. Carved and gilded.

Height, 41/2 inches.

471-WOOD CARVING

In design of a crane; gilded.

Height, 51/4 inches.

472-WOOD CARVING

Lotus flowers and wave design carved and gilded.

Height, 6 inches. 
473-WOOD CARVING

Head of dragon carved and lacquered in gold.

Height, 6 inches.

474-PAIR BANNER ORNAMENTS

Carved lions' heads gilded.

Height, 41/2 inches.

475-TEAKWOOD BOX

The cover is inlaid with porcelain of green and blue texture in Chinese characters signifying "Spring." The background is of teakwood medallions containing carved decoration of five-clawed dragons and various symbols; eight square panels of porcelain are inscribed with the Chinese symbols of longevity.

Looted from the Palace, Pekin, 1860.

8 inches square.

476-FLOIVER HOLDER

Made of bamboo wickerwork.

Height, 8 inches.

477-PAIR CARVED FIGURES

Representing a Chinese mandarin and his wife. Garments, head coverings and skirts are richly ornamented and decorated with various patterns in minute painting.

Height, $71 / 2$ inches.

478-CARVED FIGURE OF NEHANNO SHAKA

The figure is lying upon a stand of lotus flower design and coated with gold lacquer.

Length, 12 inches; height, $4 \frac{1}{2}$ inches.

479-TEAKWOOD ROUND BOX

The cover has carved design of Chinese lions playing with ball among peony flowers; the ball is of mother-of-pearl.

Diameter, 81/2 inches; height, 6 inches.

480-COLLECTION OF CHINESE INK BLOCKS

Twelve specimens, representing various temples, landscapes and famous designs. In a gold lacquer case with silk brocade cushion. Mark of Chia-Ching.

481-COLLECTION OF CHINESE INK BLOCKS

Fifty-two specimens, illustrating various Chinese celebrated places and dignitaries and famous landscape views; put up in various boxes. 
482--OBLONG TEAKWOOD BOX

Chinese. Medallions of plum blossom, bamboo and birds; lotus, pomegranates and chrysanthemum flowers in mother-of-pearl inlay.

Length, 13 inches; height, 53/4 inches.

483-COLLECTION OF SIXTY ARROW AND SPEAR HEADS

Arranged in a black lacquer stand, with six folding frames, each containing ten specimens of various shapes and sizes. Some of them signed Hisatsugu, Kidō, Masatsune, Sukemitsu, Takasuye and Tsuginori. Date, fifteenth, sixteenth and seventeenth centuries.

484-TWO MASKS

One has signature in seal, and the other is signed Amano Kiyomitsu. Dates, sixteenth and nineteenth centuries.

485-TWO MASKS

One has a signature in seal; the other signed Kagekiyo. Seventeenth century.

486-TWO MASKS

One by Hiakunen; the other by Tōkai Gwaishi. Seventeenth century.

487-TWO MASKS

Face of Ofuku, by Amano Kiyomitsu, nineteenth century; and the face of a demon, signed in seal, seventeenth century.

48S-CARVED MASK

Modelled in clay; face of an old woman. Signed Söman. Seventeenth century.

489-CABINET CONTAINING TWENTY CARVED MASKS

Used for performing "Nō" dance. Among them are specimens by Mitsunaga, Omi, Tenkaichi, Zekan, Kagemitsu and Takeda Hachiro. Dates, thirteenth and eighteenth centuries.

490-OBLONG WRITING CASE

Chinese. Carved teakwood. Elaborate decoration of medallions of flowers and Chinese seal marks, inlaid with mother-of-pearl. 
491-SQUARE TEAKWOOD TRAY

Chinese. In four panels are Chinese art objects, bunches of flowers and fruits carefully inlaid in mother-of-pearl of various tints. Bronze mountings.

91/2 inches square; height, 3 inches.

492-KEY.AKI-WOOD STAND

Upright, with openwork decoration of plum flower.

Height, 13 inches; length, 9 inches; width, 61/2 inches.

493-LARGE TEAKWOOD VASE WITH COVER

Cylindrical shape. Bold relief carving of Chinese figures, houses and trees. The cover in design of lotus leaf. The stand with openwork carving of plum-tree.

Complete height, 16 inches; diameter, 9 inches.

494-SET OF JAPANESE BATTLEDORE AND SHUTTLECOCK

One side is decorated with a group of Japanese court nobilities at a ceremonial gathering and on the reverse is a group of New Year's street performers and a group of court nobles watching them.

Length, 23 inches.

495-JAPANESE SAMISEN (MUSICAL INSTRUMENT)

Gold lacquer decoration of chrysanthemum flowers, which are inlaid with coral beads. Signed with name and residence of maker, "Yedo, Saizusai Nara Masakazu."

Total length, 39 inches.

496-JAPANESE KOTO (MUSICAL INSTRUMENT)

Made of kiri-wood. Gold lacquer and inlaid ivory decoration of storks, pine, maple and cherry trees.

Length, 76 inches.

497-PANEL CONTAINING SPECIMENS OF CHINESE COINS

Consisting of one hundred and thirty-one coins set in an old wood panel with teakwood frame. Dates range from Chow, 1200 B.c., to Ming, 1600 A.D.

From the collection of DR. J. WARD HaLl, Shanghai.

498-JAPANESE OKIMONO

Piece of gnarled wood, with carved figures and trees, representing the "Seven Worthies of Bamboo Grove." Has wood stand. 


\section{OKIMONOS AND WOOD CARVINGS}

499-OKIMLNO

Carved wood and lacquered. Demons carving the head of Shōki. By Sakacho.

Height, 10 inches; length, 15 inches.

500-FIGURE OF JAPANESE ARCHER

Carved wood and lacquer.

Height, 15 inches; width, 101/2 inches.

501-OKIMONO

Japanese boy on a large toad surrounded by numerous frogs and toads. Has stand.

Height, 14 inches.

502-OKIMONO

Life-like eagle with spread wings perched on an old branch.

Carved wood, tinted with pigments.

Height, 183/4 inches; diameter, 23 inches.

503-LARGE OKIMONO

Japanese, with trained frogs. Has lacquer and gilt stand.

Height, 22 inches; length, 17 inches.

504-TWO PRIESTS' CHAIRS

Red "shu" lacquer. Leather seats. Carved and lacquered back panel. Frames are mounted with chased brass.

TEAKWOOD STANDS FOR VASES AND ORNAMENTS

505-SEVEN TEAKWOOD STANDS

Assorted shapes and sizes.

506-FOUR TEAKWOOD STANDS

Various shapes and sizes. 
507-TWO TEAKWOOD STANDS

508-FIVE STANDS

Odd shapes.

509—SEVEN TEAKWOOD STANDS

Assorted shapes and sizes.

510-TWO TEAKWOOD STANDS

511-TWENTY-THREE STANDS

512-TWO TEAKWOOD STANDS

513-THREE TEAKWOOD STANDS

Odd shapes.

514-TWO TEAKWOOD STANDS

515-THREE TEAKWOOD STANDS

Assorted sizes.

516-THREE TEAKWOOD STANDS

517-THREE TEAKWOOD STANDS

518-TWELVE TEAKWOOD STANDS

Odd shapes.

519-TWELVE TEAKWOOD STANDS

Odd shapes.

5RO-THREE TEAKWOOD STANDS

Assorted shapes and sizes.

521-THREE TEAKWOOD STANDS

Assorted shapes and sizes. 
523-THREE TEAKWOOD STANDS

Assorted sizes.

524-THREE TEAKWOOD STANDS

Assorted sizes.

525-THREE TEAKIVOOD STANDS

Assorted sizes.

526-THREE TEAKWOOD STANDS

Assorted sizes.

527-FOUR TEAKWOOD STANDS

Assorted sizes.

528-FOUR TEAKWOOD STANDS

Assorted sizes.

529-TWO TEAKWOOD STANDS

'Table-shaped.

530-TWO TEAKWOOD STANDS

531-SIX TEAKWOOD STANDS

532-FIVE TEAKWOOD STANDS

Odd shapes.

533-FOUR TEAKWOOD STANDS

Assorted shapes and sizes.

534-FOUR TEAKWOOD STANDS

Assorted shapes and sizes.

535-SEVEN CARVED WOOD STANDS

Assorted sizes. 
5S6-THREE TEAKWOOD STANDS

Odd shapes.

537-PAIR OF CARVED WOOD STANDS

538-TWO TEAKWOOD STANDS

539-FOUR TEAKWOOD STANDS

Assorted sizes.

540-THREE TEAKWOOD STANDS

Assorted sizes.

541-FOUR TEAKWOOD STANDS

542-FIVE TEAKWOOD STANDS

Odd shapes.

543-TWO TEAKWOOD STANDS

544-FOUR TEAKWOOD STANDS

Odd shapes.

545-THREE CARVED WOOD STANDS

546-FIVE TEAKWOOD STANDS

Assorted sizes.

54\%-SIX CARVED WOOD STANDS

Assorted sizes.

548-SEVEN CARVED WOOD STANDS

Odd shapes.

549-FOUR TEAKWOOD STANDS

Assorted sizes.

550-TWO OBLONG TEAKWOOD STANDS 


\title{
THIRD AFTERNOON'S SALE
}

\author{
FRIDAY，JANUARY 19тн, 1906 \\ AT THE AMERICAN ART GALLERIES \\ BEGINNING AT 2.30 O'CLOCK
}

\section{MISCELLANEOUS CABINET OBJECTS}

551 SET OF FIVE MINIATURE FIGURES

Kwan-on and priests. Chinese workmanship. Seventeenth century.

\section{2-TRIPOD INCENSE BURNER}

Carved soapstone. Panels containing branches of cherry blossoms and chrysanthemums carved in high relief. Rosewood lid surmounted by an agate ornament. Teakwood and metal stand.

Height, 51/2 inches.

553-ORNAMENT

Filigree gold, enamelled and incrusted with seed pearls; surmounted by an ivory sphere, colored in imitation of pink coral.

554-IVORY PERFUME BOX

In two sections. Richly ornamented in pencilled gold, vermilion and gold enamels.

Height, 21/4 inches; diameter, 21/4 inches.

\section{5-CARVED AMETHYST MINIATURE CASKET}

Mounted in exquisitely wrought gold which is thickly studded with brilliants. Exceedingly fine specimen.

Length, 2 inches; height, 11/2 inches.

556-ANTIQUE JAPANESE POCKET SHRINE

Of silver. Containing a miniature Buddha standing on the sacred lotus. Exquisitely wrought in gold. 
Louis Quinze period. Of bloodstone, covered with gold exquisitely wrought in openwork and repoussé designs of foliations, birds and flowers. Stopper of gold, representing a bird with open wings dressing its plumage.

Height, 2 inches.

558-MINIATURE TAZZA

Of cut and polished topazes, mounted in silver gilt.

Height, $3 \frac{1}{2}$ inches; length, 4 inches.

559-MINIATURE PORTRAIT

"Queen Adelaide," beautifully painted on ivory. Framed in ormolu.

The above miniature was purchased at the Fitz-Clanence Sale, Berwick, Scotland, May 5, 1891, and was then stated to have belonged to King William IV.

560-MINIATURE

Portrait of a beautiful young lady of blond type. Exquisitely painted on ivory. Framed in gold.

561-MINIATURE PORTRAIT

"Mary Stuart." Finely painted on ivory. Signed, "A. J. 1567." Gilded brass frame.

562-ANTIQUE SILVER WATCH

Inscribed on the face, "Durham, London."

563-ANTIQUE GOLD WATCH

English? Surrounding the face or dial are two figures; below are baskets of flowers and an ornamental casket, and above, suspended from the fleur-de-lis, are two bells upon which the two figures strike the hours and quarters of the day with hammers.

\section{4-ANTIQUE WATCH}

The face of the movement marked "Markwick, Markham, Perigal, London." Beautiful Turkish gold and enamel case, with two movable cases of gold exquisitely wrought and enamelled and studded with two brilliants. 
Repoussé gold case. Inscribed on the face, "Windmill, London."

566-OSTRICH EGG BOX

Decoration of lotus flowers, leaves and herons elaborately painted in raised and powdered gold lacquer. Cloisonné enamel handle in design of a gourd. Interior is decorated with butterflies, Hōwō birds and floral vines in gold lacquer on a black lacquer ground. Oval-shaped ivory stand, with a decoration of peony flower painted in gold lacquer.

\section{7-OSTRICH EGG}

Gold lacquer painting of a dragon rendered in powdered and raised gold. Lacquer stand with gold lacquer decoration.

Height, with stand, $83 / 4$ inches.

568-COLLECTION OF JAPANESE LADY'S COMBS

Thirty-five specimens in gold lacquer and carved ivory, decorated with various flower designs, musical instrument, birds and landscapes, some of them with incrustations of coral, mother-of-pearl and ivory. Date about 1750-1800.

\section{9-LIMOGES ENAMEL PLAQUE}

Head of Minerva in grisaille on a ground of clouded gold. Framed in gilded bronze and mounted on a velvet panel. Maison F. Barbédienne, Paris.

Diameter, 3 $\frac{1}{4}$ inches.

\section{5\%0-LIMOGES ENAMEL PLAQUE}

"Ronde d'Enfants," after Raphael. Executed in grisaille and gold by A. Serre, 1878, for F. Barbédienne, Paris. In gilt metal frame and mounted on a velvet panel.

Height, 61/2 inches; length, 13 inches.

\section{1-LIMOGES ENAMEL PLAQUE}

"A Gallic Warrior." By A. Meyer, after Leonardo da Vinci. Beautifully produced in translucent enamels on a dark brown ground. Velvet and gilt frame. 
572-LIMOGES. ENAMEL PLAQUE

"Sybil." After Raphael. Executed in grisaille on a ground of clouded gold by A. Serre, Paris, 1875, for F. Barbédienne. Framed in ormolu and mounted on a velvet pancl.

Height, 10 inches; width, $61 / 2$ inches.

\section{ANTIQUE JAPANESE TOBACCO POUCHES}

573-TOBACCO POUCH

Green leather of soft texture. Clasp ornament of shakudo and gold, representing the long-legged man in the toils of an octopus. Carved ivory netsuke: turtles on lotus leaf. Carved wood ojime.

\section{5\%4-TOBACCO POUCH}

Japanese needlework. Inro shape. Carved bone netsuke. Metalwork ojime.

\section{5-TOBACCO POUCH}

Pocketbook shape. Polished black lacquer. Ornamented in relief with carp, crayfish and seaweeds, in mother-of-pearl, tortoise-shell and gold lacquer in relief. Mother-of-pearl netsuke; shibuichi ojime.

\section{5\%6-TOBACCO POUCH}

Carved wood. Sake-jar shape with branch of chrysanthemums and sake saucer and dipper, in relief carving. By Masakadsu. Lacquered netsuke: head of a 'Tengu; agate ojime.

\section{5;7-TOBACCO POUCH}

Made of a dried orange skin. Ornamented in relicf with a shibuichi dragon-fly and bronze lotus leaf. Wood and ivory netsuke: Daluma; wood and pigment ojime.

\section{8-TOBACCO POUCH}

In imitation of an old iron receptacle. Bone pipe-case attached, in design of fungus. 
Worm-eaten wood. Plants in gold lacquer and mouse in caricature of priest, incrusted in lead, mother-of-pearl and gold. Large carved ivory netsuke. Dog Foo holding in his mouth the sacred pearl. Agate ojime.

\section{0-TOBACCO POUCH}

Black polished leather. Decoration of vine in lacquer and motherof-pearl. Carved wood netsuke: fishes; glass ojime.

\section{1-TOBACCO POUCH}

Carved wood. Purse-shape, with three small drawers. Branch of persimmon in gold lacquer. Carved wood netsuke: bell-shape. Agate ojime.

\section{2-TOBACCO POUCH}

Green leather, with patterns in white reserve. Clasp ornament wrought in gold and silver: a group of cranes resting on a rock beneath a weeping willow. Pipe case to match pouch. Metalwork chain and a damascene iron netsuke in design of a Japanese stirrup.

\section{3-TOBACCO POUCH}

Wood, artistically carved. Monkeys on peach tree plucking the fruit. Signed by Shūosai. Carved wood netsuke and ojime of monkey and young ones. By Shūosai.

\section{4-TOBACCO POUCH, PIPE AND PIPE CASE}

Carved rosewood; elaborately ornamented. Eagle on pine branch, and rock over wave crest in relief carving and mother-of-pearl incrustation. Signed by Ikkō. Bamboo pipe-case attached, which contains an elaborately wrought silver pipe and is artistically ornamented in metals, ivory and mother-of-pearl, executed in relief, depicting an eagle on pine tree about to attack two young monkeys. Also signed by Ikkō. Carved ivory ojime: priest holding incense jar. 
Cocoanut-shell. Elaborate ornamentation carved in relief; numerous lifelike monkeys in a peach tree plucking the fruit. Reverse of cover is carved and ornamented with two monkeys in carved ivory. Signed by Ikkō. Netsuke and ojime to conform, also carved by Ikkō.

\section{6-TOBACCO POUCH}

Made of natural tree bark. Decoration of birds flying over wave crest, in incrusted metals and gold lacquer. Carved wood netsuke: Shōki crushing a demon beneath his feet. Wood and metal ojime.

\section{7-TOBACCO POUCH}

Cocoanut-shell and leather. The former ornamentated with the rain dragon amid clouds carved in relief. Carved ivory netsuke: mouse on a fish head.

\section{8-TOBACCO POUCH}

Bamboo basket-work and bronze, in design of an old Chinese shoe. Carved wood pipe-case attached, in design of a folded lotus leaf; finished in red lacquer and ornamented in relief with gold lacquer and mother-of-pearl. Amber ojime.

\section{9-TOBACCO POUCH AND PIPE CASE}

- Brown leather; iron clasp ornament. Silver chain, with ivory netsuke containing an iron openwork panel of dragon design.

590-TOBACCO POUCH AND PIPE CASE

Pouch of mother-of-pearl, with cover of black lacquer and decoration of ferns in gold. Pipe case in design of dagger, decorated to imitate fabric, silver and shakudo mounts. Amber ojime.

\section{1-TOBACCO POUCH AND PIPE CASE}

Pouch of wood carved to imitate leather. Has two small medallions, one containing floral scroll inlaid with small points of coral, mother-of-pearl and malachite, and the other a wild boar. Pipe case of ebony; carved design of a well and buckets with grasses and flowers of mother-of-pearl inlay. Metal-work ojime. 
592-TOBACCO POUCH AND PIPE CASE

Bamboo. Pouch of circular shape, with peonies carved in high relief. Pipe case profusely ornamented with poems in microscopic characters. Ojime: a carved walnut-shell.

\section{3-TOBACCO POUCH AND PIPE CASE}

Pouch of wood carved to represent tree trunk and ornamented with an oak branch and life-size locust. Cover in design of leaf with snail ornament. Ebony pipe case with ornamentation of two figures wrought in silver and inlay. Ojime of bronze snake.

\section{4-TOBACCO POUCH AND PIPE CASE}

Pouch of leather in shape of bag. Pipe case of ebonized wood ornamented with figure of demon in rain-storm, in silver and gilt. Ojime of metal.

\section{5-TOBACCO POUCH AND PIPE CASE}

Pouch of wood. Lacquered in dark brown; ornamented with Japanese sparrows, snake, and floral branches in ivory, mother-ofpearl, tortoise-shell and gold lacquer. Signed by Gioksai. Wood pipe-case, ornamented with cucumbers and vine in tinted ivory, of green and gold and mother-of-pearl. Carved openwork nut ojime.

\section{6-TOBACCO POUCH AND PIPE CASE}

Pouch of tooled leather, with floral scrolls in relief on a gold ground. Carved bone clasp ornament. Pipe case of rosewood, ornamented with branch of pomegranates in carved ivory and incrusted. Ivory ojime.

\section{7-ELABORATE POUCH, PIPE AND PIPE CASE}

Black leather of coarse grain. The clasp ornament, depicting a wild-boar hunt, is wrought in shibuichi by Sanganki. Elaborate chain and slide of shibuichi and silver. Large ivory netsuke with fine metal-work panel inserted. Pipe case contains a finely wrought silver pipe: boar, pine tree and cascade in relief. 
Brown leather of fine grain. Clasp of pouch wrought in shibuichi, gold and other metals. "Shōki attacked by demons," by Tenmin. Elaborate chain and ojime of silver and other metals. Ivory netsuke with fine metal-work panel. By Kumei. Pipe case of leather, containing a silver pipe inlaid with shakudo and other metals.

\section{9-POUCH, PIPE AND PIPE CASE}

Pouch of black leather, ornamented with an elaborate clasp of metal-work; peony and butterflies wrought in relief on a gold ground. Signed by Aki-chika. Netsuke and ojime of carved ivory. Pipe case containing a pipe attached. The pipe case is of horn in design of a pair of pincers and ornamented with a relief figure of a demon carved in ivory. Signed.

\section{0-TOBACCO POUCH, PIIE AND PIPE CASE}

Pouch of decorated leather. Clasp ornament of wood and tinted ivory: a crane perched on a pine tree; red sun in the background. Signed by Ikkō. Finely carved bone pipe-case attached, containing a fine damascened silver pipe. Amethyst ojime.

\section{1-TOBACCO POUCH}

Black leather of fine texture. Elaborate clasp ornament. Temple drums and other musical instruments wrought in silver, red bronze and shakudo. Large netsuke of carved ivory with shibuichi panel. By Yoshiaki. Agate ojime.

602-ELABORATE POUCH, PIPE AND PIPE CASE

Leather of peculiar texture. Large metal-work clasp ornament: monkeys hiding in cave. Reverse, maple leaves floating on stream. Netsuke of ivory. Peach branches carved in openwork, and shibuichi monkey inlaid. Elaborate chain and ojime of shibuichi. Pipe case contains a finely wrought metal-work pipe with ornamentation of monkeys, fruit-tree and flowers modelled in relief.

\section{3-TOBACCO POUCH AND PIPE CASE}

Pouch, in design of bag, of black lacquered wood, with panel containing flowering plants surrounded by detached flowers and leaves, the whole upon a surface of diaper patterns. Pipe case of ebony, ornamented with a group of figures in metal-work and inlaid. Green bead ojime. 
604-TOBACCO POUCH, PIPE AND PIPE CASE

Fine brown leather. The pouch ornament of gold: a dragon clutching a coral ball. Signed by Go-koku. Carved ivory netsuke with cloisonné panel. Gold and enamel ojime. Pipe case contains a shibuichi pipe with gold bowl and mouthpiece.

\section{JAPANESE PIPES AND PIPE CASES}

605-TWO PIPES

Silver bowls and mouthpieces; bamboo centres.

606-PIPE

Silver and bamboo. Elaborate ornamentation of dragons and cloud forms; engraved and gilt.

607-PIPE

Bronze. Lotus stem, pod and leaves, frog and crab in relief.

608-PIPE

Silver and bamboo. Dragons and wave designs in high relief.

609-PIPE

Silver, with bamboo stem. Dogs Foo, peonies and rocks in bold relief and inlaid with gold.

610-PIPE

Silver, with bamboo stem. Decoration of storm dragon in relief and inlaid gold.

611-PIPE

Silver. Finely wrought basket pattern in shakudo and silver.

612-PIPE

Silver, with lacquered stem. Ornamentation of flowering plants and bamboo fence, engraved and inlaid with various metals. Butterflies in gold lacquer on stem.

613-PIPE

Silver. Dragon amid cloud forms wrought in high relief. Signed by Yoshiteru. 
614-PIPE

Silver, with bamboo stem. Artistic ornamentation: carp of gold ascending waterfall; pine tree and cloud forms.

615-PIPE

Silver. Dogs Foo carved in relief.

616-PIPE

Silver. Elaborately ornamented in relief casting and chiselled work. Dragons amid cloud forms clutching the Pearl of Omnipotence in gold inlays.

$617-P I P E$

Silver and shakudo. Cherry blossoms carved in relief and coral inlays.

618-PIPE

Silver. Relief ornamentation of pine tree and storks in silver, shakudo and red bronze. Signed by Shobunsai.

619-PIPE

Silver. Artistically wrought ornamentation of Shōki chasing a demon. By Kohodo Mitsu-un.

620-PIPE

Silver and ivory. Ornamentation of storks and cloud forms.

621-CHINESE PIPE

Carved jade mouthpiece and bowl.

\section{PIPE CASES}

622-TWO PIPE CASES

Polished black wood. One ornamented with a Dog Foo and butterflies in metal and ivory; the other with a bold figure of a demon wrought in silver.

623-TWO PIPE CASES

Polished black wood. One ornamented with a Dog Foo in gold on a silver stand; the other engraved and ornamented with a figure of a priest in gold, silver and red bronze. 
624-PIPE CASE

Polished black wood. Ornamented in silver with a seated figure of

a Japanese poet. Inscription, " a news reading-room."

\section{5-PIPE CASE}

Polished black wood. Ornamentation representing a three-claw dragon amid cloud forms chasing the Pearl of Omnipotence; the dragon finely wrought in gold. Signed by Hoto. Gold work by Rio-nen.

\section{6-PIPE CASE}

Black wood. Of corrugated design, with a finely wrought shibuichi ornament representing a fisherman spearing a large carp.

\section{7-TWO PIPE CASES}

One carved bamboo. Incrusted with ivory and lacquer. A combat between a warrior and storm dragon; the other ornamented with a flowering plant carved in relief.

628-PIPE CASE

Design of a dagger. Surface lacquered in imitation of tree bark; mountings finely wrought in shibuichi and other metals.

629-PIPE CASE

Bone. Wood-gatherer descending mountain path; finely carved in high relief. Signed, Kiō-min.

630-PIPE CASE

Bone. Etched ormamentation; gardener in rain coat and hat. Signed by Reigioku.

631-PIPE CASE

Bone. Finely carved and ornamented. Figure of laborer with rake carved in relief. Stork in flight wrought in gold and inlaid. Carved by Roku-min.

Bone. Carved ornamentation: mask and dragon. Signed by Shō-an. 
6s9-PIPE CASE

Bone. Carved and ornamented with gold figures: a Japanese interior. Signed by So-min. Gold work by Ritsumin.

634-PIPE CASE

Bone, tinted green. Silver dragon in relief.

635-PIPE CASE AND PIPE

The pipe case of bone. Artistically ornamented with an exquisitely wrought gold figure of a deity on a silver dragon amid cloud forms. Signed by Tokokusozui. Metal-work by Shuroku. The pipe of silver and iron. Weeping willow in gold and silver inlay.

SPECIMENS OF JADE, AGATE AND OTHER STONES

636-THREE SMALL FEI-TS'UI ORNAMENTS

Carved gourd and floral design.

63\%-TWO NETSUKES

Jade and turquoise.

638-AMULET

Dark green jade. Carved face of a deity.

639-AXE HEAD

Green jade.

640-WINE CUP

Moss-green jade.

641-FIVE BEADS

Jade stone. Emerald green markings.

642-SMALL UPRIGHT PANELS

Gray and white jade, carved in openwork floral design.

643-THREE JADE BOOK-MARKERS

White texture; incised Grecian patterns. 
644-THREE AMULETS

Gray and brown jade, highly polished.

645-DAGGER HANDLE

White jade, with floral sprays carved in low relief.

646-SEVEN WINE CUPS

Green and gray jade.

647-JADE CUP AND SAUCER

Mottlẹd green and gray jade.

648-SIX SMALL CUPS AND SAUCERS

Mottled green jade.

649-THREE MINIATURE WINE CUPS

Gray jade; highly polished surface.

650-TWO SMALL CUPS AND TRAYS

Leaf design. Carved jade of gray texture; polished surface.

651-SEVEN SMALL CUPS AND SAUCERS

Gray jade; highly polished surface.

652-SIX SMALL CUPS AND SAUCERS

Moss-green jade.

653-ROUND FLAT TRAY

Gray jade; highly polished surface.

Diameter, 6 inches.

654-TWO JADE DISHES

Gray texture; highly polished surface.

Diameter, 61/2 inches.

655-JADE DISH

Gray texture; highly polished surface. 
656-SMALL OBLONG TRAY

Indian jade, of gray opaque texture. Carved shou mark and Greek fret border.

\section{Length, 7 inches; width, $51 / 2$ inches.}

657-TWO JADE SAUCERS

Gray texture; highly polished.

658-CARVED JADE WINE PITCHER

Gray texture; highly polished surface.

Height, 2 inches.

659-JADE TEAPOT

Gray texture; polished surface.

Diameter, $4 \frac{1}{2}$ inches.

660-FOUR INDIA JADE SAUCERS

Gray texture; engraved ornamentation of floral and leafy scrolls. Diameter, $51 / 2$ inches.

661-TWO BUCKLE ORNAMENTS

White jade; carved in openwork. Melon and peach design.

662-SMALL STONE BOTTLE

Plum tree in blossom and birds; carved in high relief.

663-AMETHYST ORNAMENT

Carved lily design.

664-TWO STONE AMULETS

Carved archaic designs.

665-STONE PERFUME BOX

Incised inscription.

666-AGATE BEADS

Various.

667-FIVE ANCIENT BEADS

Stone and jade. 
668-MINIATURE STATUETTE

Carved in mother-of-pearl. Chinese lady in trailing robe and holding in her hand a vase.

669-TWO JADE ORNAMENTS

(a) Miniature figure.

(b) Group of gourds.

670-FOUR SMALL ORNAMENTS

In carved jade and agate.

671-TWO SMALL OBJECTS

(a) Jade snuff bottle.

(b) Ornament of white and brown texture.

672-TWO SMALL ORNAMENTS

Carved white jade; iris and peach designs.

673-TWO SMALL ORNAMENTS

(a) Carved white jade fish.

(b) Buddha's fruit, in agate.

674-JADE SEAL

Green and gray texture.

675-JADE ORNAMENT

White texture.

676-SMALL COUPE

Grourd design; carved green jade. Teakwood stand.

677-TWO SMALL JADE OBJECTS

(a) Gray jade saucer.

(b) Gray and white floral disk.

678-TWO JADE PANELS

Gray texture; dragon and floral designs carved in openwork.

679-FOUR SMALL PANELS

Heart-shaped; white jade. Dragons amid cloud forms carved in openwork. 
680-JADE SNUFF BOTTLE

White texture; carved in low relief.

681-JADE STATUETTE

Seated figure of a priest; yellow texture. Teakwood stand.

682-SIX SSMALL MEDALLIONS

White jade. Bird and floral designs carved in openwork.

683-TWO SMALL PANELS

White jade. Dragon and fabulous animal carved in openwork.

684-THREE SMALL OBJECTS

(a) Yellow jade girdle ornament.

(b) Gray and green jade ring.

(c) White jade earring.

685-TWO ORNAMENTS

White jade; carved floral design.

686-TWO SMALL MEDALLIONS

White jade. Symbolical designs carved in openwork.

68\%-TWO OPENWORK DISKS

Gray jade; symbols and floral designs.

688-FIVE OPENWORK MEDALLIONS

White and gray jade; intricate designs of figure, symbols and coins.

689-TWO JADE ORNAMENTS

White and gray jade. Peach and melon design carved in openwork.

690-TWO GRAY JADE ORNAMENTS

(a) Carved basket.

(b) Oval panel, with lizards in relief.

691-THREE JADE SPECIMENS

(a) Buckle, of gray texture, with carving in low relief.

(b) Oval ornament; melon and vine in openwork carving.

(c) Oblong panel. Dragon and cloud forms in intricate openwork. 
692-TWO JADE ORNAMENTS

Gray and brown texture.

(a) Dragon and cloud forms in intricate openwork.

(b) Group of kylins, carved in relief and undercut.

693-PAPER KNIFE

Bloodstone; highly polished.

694-TWO JADE PANELS

Gray and white texture.

695-JADE SPHERE

Mottled green texture.

696-TWO JADE HAIRPINS

Carved lily design.

69\%-FOUR WINE CUPS

Gray white jade; highly polished.

698-TWO MINIATURE FIGURES

Chinese children; carved in white jade.

699-JADE BUCKLE

Cord design in openwork carving.

700-GRAY JADE ORNAMENT

Design of a spear-head; in relief and openwork carving.

701-SMALL JADE TRAY

Gray texture. Dragons carved in high relief.

702-YELLOW JADE VASE

Carved bamboo design. Teakwood stand.

703-SMALL RECLINING FIGURE

Carved gray jade. Teakwood stand.

704-TWO JADE BUCKLES

White texture. 
705-SMALL OVAL COUPE

Yellow and brown jade.

706-TWO GRAY JADE PANELS

Dragon, cloud forms and floral designs in intricate openwork carving.

70\%-TWO GRAY JADE PANELS

(a) Round panel, with bird and lotus in openwork carving.

(b) Convex panel; peonies and butterflies carved in relief.

708-TWO GRAY JADE PANELS

Figures and symbols carved in relief.

7O9-TWO JADE ORNAMENTS

(a) White jade vase, with relief carving.

(b) Oval concave panel, with branch of peach fruit and symbolical bats; carved in relief.

710-WHITE JADE PANEL

Branch of peach fruit and symbolical bats, carved in high relief.

711-GRAY JADE DISK

Chinese characters carved in low relief.

712-GRAY JADE ORNAMENTS

Kylins and peony in relief and openwork carving.

"13-CUP STAND

Lotus design; carved in green jade.

714-LIBATION CUP

Gray jade. Teakwood stand.

715-PERFUME BOX

Gray and brown jade. Carved peach design. Teakwood stand.

116-SMALL OVAL TRAY

Moss-green jade; highly polished.

717—SMALL PANEL

Gray jade. Figures, bamboo and scrolls in intricate openwork carving. 
718-TWO OPENWORK PANELS

(a) Peach fruit, fungus and flowers in gray jade.

(b) Dragon amid cloud forms and symbols, in white jade.

719-GREEN JADE PANEL

Lotus and foliated patterns, in intricate openwork carving.

720-WHITE JADE PANEL

Basket of fruit and scrolls, carved in low relief.

721-TWO OPENWORK PANELS

White jade. Dragon and cloud forms in intricate pierced design.

722-WHITE JADE PANEL

Dragons, cloud forms and floral sprays, carved in openwork.

'723-PAIR GRAY JADE PANELS

Dragons, floral sprays and cloud forms in intricate openwork carving.

724-INDIAN JADE SAUCER

Green and gray texture; carved borders and highly polished surface.

725-FEI-TS'UI BOWL

Highly polished surface. Carved teakwood stand.

726-PAIR OPENWORK PANELS

Gray jade. Dragon, cloud forms and flowers carved in openwork. Teakwood stand.

YR\%—PRIEST'S SCEPTRE

Fungus design, finely carved in green jade.

728-JADE CYLINDRICAL VASE

Dense green, yellow and white texture. Dragon and symbols carved in low relief.

Height, 31/2 inches.

729-JADE COUPE

Gray-white texture. Bird holding fungus in bill, carved in high relief. 
Butterfly, composed of fei-ts'ui jade and metal. In small glass case.

731-CARVED JADE ORNAMENT

A recumbent horse, carved in yellow jade. Carved teakwood stand.

Length, 51/2 inches; height, 4 inches.

732-GRAY JADE ORNAMENTAL PIECE

Kylin and puppy, finely carved and polished. Carved teakwood stand.

$$
\text { Length, } 5 \frac{1}{2} \text { inches; height, } 3 \text { inches. }
$$

\section{9- $J A D E \quad V A S E$}

Flat bottle shape; gray texture. Floral and archaic designs carved in low relief.

$$
\text { Height, 51/2 inches. }
$$

"34-GRAY JADE TRAY

Octagonal-shaped. Dragons and symbols carved in high relief. Diameter, 6 inches.

735-JADE BOWL

Gray and mottled green texture; highly polished surface.

Diameler, $5 \frac{3}{4}$ inches.

736—SUPERB JADE BOWL

On high foot; gray texture. Lotus design with intricately carved openwork panels, containing the eight Buddhistic symbols of happy omen and foliated scrolls.

Height, 33/4 inches; diameter, $4 \frac{1}{2}$ inches.

"3\%-BEAUTIFUL INDIA JADE TEAPOT

With stand. Gray texture; finely carved and highly polished. Handle of floral spray and loose ring. Stand of delicate openwork.

Height, including stand, 51/2 inches; diameter, 4 inches.

738-GREEN JADE VASE

Flat bottle-shaped; archaic designs carved in relief. Teakwood stand.

Height, 61/2 inches.

739-DISH

Moss agate; highly polished.

Diameter, $71 / 2$ inches. 
740-IMPERIAL BOWL STAND

Of agate; carved and highly polished.

741-ELABORATE JADE STAND

Carved lotus design.

742-ANTIQUE STEATITE

Imitating jade. Conventional dragon design.

743-RECLINING FIGURE

Carved stone.

"44-TWO GREEN JADE STANDS

Finely carved in openwork.

745-GRA $Y$ JADE DISH

Polished surface.

Diameter, $61 / 2$ inches.

746-TWO JADE VASE COVERS

Green and gray texture; carved in openwork.

747-PAIR JADE STATUETTES

Gray texture. Chinese philosopher and attendant. Teakwood stand.

748-PAIR GREEN JADE SAUCERS

Finely carved chrysanthemum design.

749-WHITE JADE DISH

On low foot. Symbols and archaic designs carved in high and low relief.

Diameter, 6 inches.

750-COVERED BOX

Mottled green jade. Shou symbol in relief. Carved stand.

751-ORNAMENTAL PIECE

Jar, flowering plant and sprouting bulbs, composed of various jades.

752-SPECIMEN OF GREEN JADE

Carved and polished. Teakwood stand.

Length, 9 inches. 
753-PAIR HANDSOME PLATES

Mottled green jade. Chrysanthemum design; carved and highly polished.

Diameter, 71/2 inches.

754-COVERED KORO

Gray jade. Carved in intricate openwork. Teakwood stand. Height, 41/2 inches.

755-MOTTLED GREEN JADE PANEL

Decoration of figures, pine and bamboo in enamel.

756-GRAY JADE ORNAMENTAL PIECE

Dragon, cloud forms, Sacred Pearl and other designs, boldly carved in openwork. Teakwood stand.

Height, 6 inches.

75\%-WRITING-T'ABLE SCREEN

Disk of white jade, ornamented with boating and other scenes artistically carved in high relief. Mounted on a carved teakwood stand.

Diameter, 6 inches.

758-WRITING-TABLE SCREEN

Oblong panel of gray-white jade; elaborately carved in relicf on both sides with Chinese mountain scenery. Mounted in teakwood. Height, including stand, 15 inches.

759-PRIEST'S ELABOR.ATE SCEPT'RE

Mottled green jade. Fungi design, with branches of plum blossoms carved in high relief and undercut.

760-PRIEST'S SCEPTRE

Mottled gray jade. Figures and garden scenes in relief carving.

\%61-LARGE KORO

Fine mottled green jade. Archaic designs carved in low relief. Handles of openwork design and cover surmounted by an ornament carved in openwork. Teakwood stand.

Height, 61/2 inches.

762-GREEN JADE VASE

Fashioned after an ancient bronze. Archaic and palm leaf patterns carved in low relief. Dragon head and loose ring handles on neck. 
763-LARGE CYLINDRICAL VASE

Thick gray-white texture. Ornamentation of Chinese mountain scenery finely carved in high and low relief.

Height, $81 / 2$ inches; diameter, $61 / 2$ inches.

764-LARGE WRITING-TABLE SCREEN

Ornamented with a landscape and garden view composed of carved jade, amethyst and agate applied in relief on teakwood.

Height, 16 inches; width, 12 inches.

765-COLLECTION OF JADE SPECIMENS

Twenty panels of various shapes and sizes of gray jade; carved in intricate openwork.

766-COLLECTION OF JADE SPECIMENS

Tray containing thirteen white jade ornaments and panels, finely carved in openwork.

767-COLLECTION OF JADE SPECIMENS

Tray containing thirteen white jade ornaments and buckles; finely carved.

T68-LARGE MALACHITE VASE

Crudely shaped. Carved teakwood stand.

Height, $91 / 2$ inches.

769-LARGE WRITING-TABLE SCREEN

Panel of stone, ornamented with pagodas, pine trees, rocks and cloud forms; elaborately carved in high relief in the matrix. Framed in teakwood.

Height, including stand, 211/2 inches; width, 14 inches.

770-BEAUTIFUL PALACE TABLE SCREEN

Of carved teakwood, with five large upright and five square panels of moss-green jade, which are ornamented with scenes from Chinese mythology. Beautifully carved in low relief. Seal mark, K'anghsi period. 
Of gilded and enamelled brass, with various panels of white jade, which are of carved openwork design; consists of :

(a) Tall incense burner of archaic design, supported by four elephant heads, and with an openwork cover which is surmounted by a repoussé and openwork ornament representing a dragon amid cloud forms chasing the Sacred Pearl.

Height, including teakwood stand, 111/2 inches; width, 13 inches.

(b) Pair quadrilateral, beaker-shaped vases containing branches of the Sacred Fungus, which are incrusted with jade, agate and lapis lazuli.

$$
\text { Height, including teakwood stand, 24 inches. }
$$

(c) Pair tall candlesticks, surmounted by repoussé gilt brass ornaments which are removable.

Height, including teakwood stand, 21 inches.

\section{SNUFF BOTTLES AND SPECIMENS OF CHINESE GLASS}

772-SNUFF BOTTLE

Carved stone; pierced panels and dragons in relief and undercut.

Yั3-TWO SNUFF BOTTLES

Carved stone; floral patterns in relief in pierced panels.

774-TWO SNUFF BOTTLES

(a) White glass; relief ornamentation in blue.

(b) Milk-white glass, with relief ornamentation in ruby-red. Ch'ien-lung period.

\section{7ry5-TWO SNUFF BOTTLES}

(a) Opal glass, with relief ornamentation in ruby-red.

(b) Milk-white glass. Gourd shape, with archaic inscription in relief in red. Ch'ien-lung period.

7y6-SNUFF BOTTLE

Chinese cloisonné enamel. Birds and floral sprays in various colors on turquoise-blue ground. Ch'ien-lung period. 
צM7-TWO SNUFF BOTTLES

(a) Milk-white glass, with show mark and bat symbol in relief in blue.

(b) White glass, with dragons in relief in red. Ch'ien-lung period.

\section{8-TWO SNUFF BOTTLES}

(a) Milk-white glass; lapis lazuli cloudings.

(b) Frosted glass, with butterfly and inscription in relief in black. Ch'ien-lung period.

\section{N79-SNUFF BOTTLE}

Salmon-pink glass, with flowering shrub in high relief in green and white. Ch'ien-lung period.

\section{0-TWO SNUFF BOTTLES}

(a) Camphor glass, with plum and pine tree in relief in ruby-red.

(b) Milk-white glass, with carp in relief in red. Ch'ien-lung period.

\section{1-SNUFF BOTTLE}

Chinese cloisonné enamel. Shou mark and dragons in yellow panels. Rose-pink ground, blue and white border. Ch'ien-lung period.

\section{2-SNUFF BOTTLE}

Carved stone.

\section{3-TWO SNUFF BOTTLES}

(a) Milk-white glass. Carp and lotus plant in relief in ruby-red.

(b) Milk-white glass. Fish in relief in dark blue.

784-SNUFF BOTTLE

Mottled yellow composition; dragon and shou mark carved in relief in red. Ch'ien-lung period.

\section{5-SNUFF BOTTLE}

Cinnabar lacquer on bronze. Finely carved ornamentation of figures and garden scene. Ch'ien-lung period. 
786-TWO SNUFF BOTTLES

(a) Camphor glass, with relief ornamentation in ruby-red.

(b) White glass, with dragon and inscription in blue. Ch'ienlung period.

78\%-SNUFF BOTTLE

Amber glass, with intricate ornamentation on the inner surface.

Ch'ien-lung period.

788-TWO SNUFF BOTTLES

(a) Milk-white glass, with zodiac symbols in relief in brown.

(b) Camphor glass, with hawk, bamboo, lotus and crane in relief in emerald green. Ch'ien-lung period.

789-TWO SNUFF BOTTLES

(a) Camphor glass, with figures, pine and peach trees in relief in red.

(b) Camphor glass. Lotus plants and geese in relief in red. Ch'ien-lung period.

790-TWO SNUFF BOTTLES

(a) Milk-white glass, with crest in relief in red.

(b) In red and yellow composition. Ch'ien-lung period.

791-TWO SNUFF BOTTLES

(a) Ruby-red glass.

(b) Milk-white glass, with flowering plants in relief in red.

Ch'ien-lung period.

792-TWO SNUFF BOTTLES

(a) Sapphire-blue glass.

(b) Emerald-green glass. Ch'ien-lung period.

793-TWO SNUFF BOTTLES

(a) Pink and white camphor glass.

(b) Mottled blue. Ch'ien-lung period.

794-TWO SNUFF BOTTLES

(a) Amber glass.

(b) Mottled blue and white glass. Ch'ien-lung period. 
795-SNUFF BOTTLE

Chinese cloisonné enamel. Shou mark and dragons in pink panels: dark blue and white ground with floral scrolls. Ch'ien-lung period.

796-SNUFF BOTTLE

Sapphire-blue translucent enamel, with floral sprays and symbols in metallic lustre. Ch'ien-lung period.

797-TWO SNUFF BOTTLES

(a) Mottled amber glass.

(b) Blue glass. Ch'ien-lung period.

798-TWO SNUFF BOTTLES

(a) White glass in imitation of jade.

(b) Mottled white and green glass in imitation of fei-ts'ui. Ch'ienlung period.

799-TWO SNUFF BOTTLES

(a) Yellow-white glass, in imitation of jade.

(b) Mottled brown glass, in imitation of agate. Ch'ien-lung period.

800-TWO SNUFF BOTTLES

(a) Gray and mottled green glass, in imitation of jade.

(b) Yellow glass, in imitation of agate.

801-TWO SNUFF BOTTLES

(a) Mottled green glass, in imitation of fei-ts'ui.

(b) Yellow and white glass, in imitation of agate.

802-TWO SNUFF BOTTLES

Composition, in imitation of turquoise.

803-TWO SNUFF BOTTLES

(a) White glass, in imitation of jade, with floral spray carved in relief.

(b) Mottled glass, in imitation of agate.

804-TWO SNUFF BOTTLES

(a) Gray jade stone, with emerald-green spots.

(b) White glass, in imitation of crystal. 
805-SNUFF BOTTLE

White jade. Gourd-shaped symbols and floral spray carved in high relief.

806-SNUFF BOTTLE

Pistache-green glass. Relief ornamentation of lotus and archaic design.

80\%-NETSUKE

Turquoise glass; gourd design. Metal mounting.

808-TWO BRACELETS

Green and yellow glass, in imitation of jade.

809-LAPIS LAZULI ORNAMENT

Design of a pomegranate.

810-TWO SPECIMENS OF ROCK CRYSTAL

(a) Vase of lily design.

(b) Girdle ornament.

Both carved in relief.

811-SMALL VASE

'Turquoise-blue glass. Ch'ien-lung period.

812-SMALL OVIFORM VASE

Milk glass. Ch'ien-lung period.

Height, 4 inches.

813-SMALL BOTTLE-SHAPED VASE

Octagonal-shaped. Sage-green glass. Yung Chêng seal mark engraved underneath foot.

Height, 51/2 inches.

814-CIRCULAR COUPE

Imperial yellow glass. Yung Chêng character mark incised underneath foot. Teakwood stand.

Diameter, 5 inches.

815-BOTTLE-SHAPED VASE

Octagonal shape. Sapphire-blue glass. Yung Chêng character mark underneath foot.

Height, 6 inches. 
816-INCENSE BURNER ON TRIPOD

Sapphire-blue glass. Engraved character mark of Yung Chêng underneath foot. Carved teakwood stand.

Diameter, $4 \frac{1}{2}$ inches.

817-LARGE GLASS VASE

Globular body with tall, flaring neck. Violet opaque glass. Ch'ien-lung period.

Height, 18 inches.

\section{PALACE AND TEMPLE WALL DECORATIONS}

818-JAPANESE WALL PANEL

Decorated with various lacquers. An earthen bowl, teapot, swallows, maple leaves and insects. Japanese fabric frame.

Height, 13 inches; length, 17 inches.

819-OLD CHINESE WALL PANEL

Brown stone. Grape vine in bearing and mice; carved in high relief in the matrix. Bamboo frame.

Height, 12 inches; length, 151/2 inches.

820-OLD CHINESE WALL PANEL

Black-lacquered. Tree peony and magnolia in bloom in xpplied porcelain and decorated in enamel colors. Framed in carved teakwood.

Height, 23 inches; width, 161/2 inches.

821-OLD CHINESE WALL PANEL

Tree peonies in bloom and birds on branch, in decorated porcelain applied in relief on a lacquered ground. Seal mark inlaid.

Height, 161/2 inches; length, 271/2 inches.

822-OLD CHINESE WALL PANEL

Peonies and butterfly in porcelain, incrusted in lacquer and decorated. Framed in carved teakwood.

Height, 17 inches; length, 22 inches.

823-JAPANESE WALL PANEL

A basket of fruits and two butterflies. Painted in gold and other lacquers and inlaid with mother-of-pearl on a mirror-black ground. Signed by Yegami Sozan. Framed.

Height, 15 inches; length, 19 inches. 
824-JAPANESE WALL PANEL

Mountain and maple trees, by moonlight, in gold lacquer and inlays of mother-of-pearl and lead. Poem on ancient places in Japan by eight poets. By Höitsu. Lacquer work by Yöyūsai.

Height, 14 inches; length, 29 inches.

825-PAIR JAPANESE WALL PANELS

Hanging basket of flowers and fruits, birds and insects. Incrusted in carved and tinted ivory. and mother-of-pearl.

Height, 42 inches; width, 12 inches.

826-PAIR JAPANESE WALL PANELS

Kiri-wood. Ornamented in high relief in lacquers, carved and tinted ivory. On one a large bronze temple bell, a bird and leaves, and on the companion piece are birds and falling leaves. By Shimamura Shunmei and signed. Framed in rosewood.

Height, 33 inches; width, 16 inches.

827-JAPANESE WALL PANEL

Representation of rice culture on a mountain side. Painted in various lacquers. By Zeshin, at the age of \%2.

Height, 23 inches; length, 28 inches.

828-JAPANESE WALL PANEL

Lacquered to represent sheet copper, and ornamented with lotus, chrysanthemums and sparrow, in porcelain and pigments applied in relief. Signature of artist in seal mark.

Height, 291/2 inches; width, 20 inches.

The above specimen is illustrated in AudsLEx's "Ornamental Arts of Japan."

829-PAIR PALACE WALL PANELS

Old Chinese. Elaborate ornamentation of groups of Chinese figures, various objects of art, fruits, flowers and symbols, artistically executed in jades, porcelain, tinted ivory, cloisonné enamels and carved lacquers, all applied in high relief. Incised inscription and seal mark. Framed in rosewood.

Height, 34 inches; width, 25 inches.

850-PAIR PALACE WALL PANELS

Old Chinese. Elaborate ornamentation of lotus in bloom, in carved green and white jade and applied in high relief. Framed in rosewood.

Height, 36 inches; width, 28 inches.

881-A SERIES OF UNIQUE TRANSPARENT PANELS

Old Chinese. Seventeen pictures of historical and domestic scenes. Painted on paper and mounted between threads of spun glass. 


\section{FOURTH AFTERNOON'S SALE \\ SATURDAY，JANUARY 20тн, 1906 \\ AT THE AMERICAN ART GALLERIES \\ BEGINNING AT 2.30 o'CLOCK}

\section{SPECIMENS OF BLUE AND WHITE}

832-MINIATURE VASE

Clear white porcelain. Boating and garden scene in fine underglaze blue. Four-character mark of Yung Chêng period. Teakwood stand.

833-SNUFF BOTTLE

Soft paste, with brown crackle glaze. Mythological subject pencilled in fine blue. Four-character mark of Yung Chêng period. Teakwood stand.

834-ROUGE BOX

Clear white hard paste. Decoration of horses in brilliant underglaze blue. Six-character mark pencilled in blue. Teakwood stand.

\section{5-ROUGE BOX}

- Clear white hard paste. Decoration of garden scenes and figures in fine mazarine blue. Mark of bat symbol underneath foot. Yung Chêng period. Teakwood stand.

\section{6-MINIATURE JAR}

Clear white hard paste of thin texture. River and mountain scenery pencilled in fine underglaze blue. Ch'ien-lung period. Teakwood stand. 
Clear hard paste. Decoration of melon vines in bearing, painted in fine cobalt blue underneath the glaze. Four-character mark of Yung Chêng period. Carved teakwood stand.

838-SNUFF BOTTLE

Chinese soft paste. Decoration of masked figures in two shades of underglaze blue. Four-character mark of Yung Chêng period. Teakwood stand.

\section{9-MINIATURE GALIPOT}

Clear white hard paste. Decoration of five-clawed dragons pursuing the Sacred Pearl, cloud forms and fire emblems painted in fine underglaze blue. Four-character mark of Yung Chêng period. Teakwood stand.

\section{0-WRITER'S WATER JAR}

Thin white porcelain. Decoration of dragons, cloud forms and fire emblems pencilled in brilliant underglaze blue. Ch'ien-lung period. Carved teakwood stand.

\section{1-SOFT PASTE PI-T'UNG}

Cylindrical shape. Soft white paste with brown crackle. Decoration in two shades of underglaze blue of a Chinese sage seated beneath a pine tree with goats about him. Chia-ch'ing period. Teakwood stand.

$$
\text { Height, } 3 \text { inches. }
$$

From the Braxton Ives Cor.fection, March, 1891, Catalogue No. 49.

\section{2-WALL VASE}

Semi-bowl shape. Decoration of melon vine in bearing and butterfly painted in two shades of blue. K'ang-hsi period.

Height, $3 \frac{1}{2}$ inches.

\section{3-SMALL BOTTLE-SHAPED VASE}

Clear white hard paste. Decoration of dragon, fire emblems and band of palmettes in cobalt blue, painted under the glaze. Fourcharacter mark underneath the foot. Teakwood stand. 
844-SMALL OVIFOFM JAR

Clear white hard paste. Band of sceptre heads in brilliant underglaze blue and floral scrolls in white reserve. Ch'ien-lung period. Teakwood stand.

Height, 3 inches.

845-SMALL BOTTLE-SHAPED VASE

Oviform, with slender neck. White hard paste. Decoration of flowering plants, rocks and insects, in two shades of cobalt blue. Ch'ien-lung period. Teakwood stand.

Height, 5 inches.

845-BLUE AND WHITE CUP-SHAPED VASE

Clear white porcelain of the Yung Chêng period. Decoration of numerous floral panels in two shades of underglaze blue. Has teakwood stand.

Height, 51/4 inches.

847-SMALL OVIFORM VASE

Clear white hard paste. Decoration of floral panels in light shades of underglaze blue. Yung Chêng period. Teakwood stand.

Height, 51/2 inches.

848-SMALL OVIFORM JAR

Clear white hard paste. Decoration of flowering plants and rocks in brilliant cobalt blue. Leaf mark underneath foot. Yung Chêng period. Teakwood stand.

Height, 41/2 inches.

849-SMALL OVIFORM JAR

Companion to the preceding.

850-SMALL JAR

Oviform. Clear white porcelain of the Yung Chêng period. Floral panels pencilled in fine underglaze blue. Teakwood stand.

Height, 31/2 inches.

851-SMALL OVIFORM JAR

Clear white hard paste. Decoration of floral panels in two shades of underglaze blue. Yung Chêng period. Carved teakwood stand. 
Ovoid shape. Clear white porcelain of the Yung Chêng period. Decoration of floral panels in brilliant mazarine blue. Leaf mark underneath foot. Carved teakwood stand.

Height, $4 \frac{1}{2}$ inches.

853-SMALL GALIPOT JAR

Clear white hard paste of the Ch'ien-lung period. Decoration of carnations amid leafy scrolls in fine underglaze blue. Carved teakwood stand.

Height, 41/2 inches.

854-PAIR GLOBULAR JARS

Clear white hard paste of the Ch'ien-lung period. Decoration of sacred flowers amid leafy scrolls in underglaze blue of brilliant quality. Mounted as inkstands in silver gilt, with chiselled ornamentation. Carved teakwood stand.

Diameter, 3 inches.

855-BOTTLE FOR ROSE WATER

Old Chinese blue and white porcelain. Clear white texture, capped with silver. Teakwood stand.

Height, 61/2 inches.

856-BOTTLE FOR ROSE WATER

Chinese hard paste. Chrysanthemums in white reserve and floral sprays in underglaze blue. Capped with gilded metal. Teakwood stand.

$$
\text { Height, 61/2 inches. }
$$

85\%-BOTTLE FOR ROSE WATER

Clear white hard paste of the Ch'ien-lung period. Decoration of flowering plants in fine underglaze blue. Silver gilt cap. Teakwood stand.

Height, $71 / 2$ inches.

858-ROSE-WATER BOTTLE

White hard paste of the Ch'ien-lung period. Decoration of flowering shrubs in two shades of cobalt blue. Silver gilt mountings. Teakwood stand.

Height; 7 inches.

859-GOURD-SHAPED VASE

Clear white porcelain of the Yung Chêng period. Decoration of blossoms and rocks in brilliant underglaze blue. Teakwood stand. 
860-SMALL PEAR-SHAPED VASE

Soft paste of the Ch'ien-lung period. Decoration of floral scrolls in rich cobalt blue. Band of upright palmettes round neck. Teakwood stand.

Height, $7 \frac{1}{2}$ inches.

861-SMALL GOURD-SHAPED VASE

White hard paste of the Yung Chêng period. Decoration of flowering plants, various ornaments and symbols in two shades of blue. Teakwood stand.

Height, 7 inches.

862-ROSE-WATER BOTTLE

White hard paste of the Yung Chêng period. Flowering plants in underglaze blue. Silver mounting. Teakwood stand.

Height, $7 \frac{1}{2}$ inches.

863-CYLINDRICAL JAR

Fên-ting (soft paste) of K'ang-hsi period. . Thin texture. Decoration of the "Hundred Antiques" in underglaze blue of brilliant quality.

Height, 51/2 inches.

864-ROSE-WATER BOTTLE

Gourd shape. White hard paste. Panel decoration, various ornaments, symbols and flowering plants in rich cobalt blue. Silver mounting. Teakwood stand.

865-BEAKER-SHAPED VASE

Height, $71 / 2$ inches.

White hard paste of the Ch'ien-lung period. Decoration of characters and borders in dark underglaze blue.

Height, 5 inches.

866-GALIPOT VASE

White hard paste of the K'ang-hsi period. Decoration of peonies amid leafy scrolls in two shades of underglaze blue. Teakwood stand.

Height, 61/2 inches.

86\%-GALIPOT VASE

Companion to the preceding. Teakwood stand.

Height, 61/2 inches.

868-BOTTLE-SHAPED VASE

Clear white porcelain of the K'ang-hsi period. Decoration of various ornaments, floral sprays, symbols and rocks in underglaze blue of brilliant quality. Teakwood stand. 
869-BOTTLE-SHAPED VASE

White hard paste of the K'ang-hsi period. Decoration of flowering plants and rocks in two panels, and various ornaments and symbols in brilliant underglaze blue. Teakwood stand.

Height, 71/2 inches.

8\%O-BEAKER-SHAPED VASE

Fên-ting (soft paste) of fine texture. Decoration of palmations and archaic designs in underglaze blue of brilliant quality underneath a crackle glaze. Ch'ien-lung period.

Height, 51/4 inches.

871-BOTTLE-SHAPED VASE

Decoration of conventionalized dragons and cloud forms in mazarine blue applied under the glaze. Six-character mark of K'anghsi pencilled in blue underneath the foot. Teakwood stand.

Height, 7 inches.

872-OVIFORM VASE

Thin texture of the soft paste type. Decoration of willow tree, tree peony and rocks finely painted in underglaze blue of brilliant quality. The glaze is marked with large crackle. Yung Chêng period. Teakwood stand.

Height, 73/4 inches.

873-OVIFORM JAR

White hard paste of the $K^{\prime}$ 'ang-hsi period. Bands of sceptre heads round shoulder and foot, and on the body sprays of blossoms, in fine underglaze blue. Teakwood stand.

Height, 71/2 inches.

874-ROSE-WATER BOTTLE

White hard paste. Floral scrolls in underglaze blue.

Height, 7 inches.

875-ROSE-WATER BOTTLE

Clear white hard paste. Floral scrolls and sprays in rich underglaze blue. Has teakwood stand.

Height, 73/4 inches.

876-TALL CYLINDRICAL VASE

Clear white thick porcelain of the $\mathbf{K}^{\prime}$ ang-hsi period. It is decorated with nine large blossoms of the idealized flowers known as the flower of paradise, and an elaborate foliation, all beautifully pencilled in underglaze blue of exceedingly fine quality. Metal collar. Carved teakwood stand. 
Clear white hard paste. Decoration of cluster of pomegranates, floral scrolls and palmettes in brilliant cobalt blue. Has teakwood stand.

Height, 7 inches.

878-BOTTLE-SHAPED VASE

Clear white porcelain of the Ch'ien-lung period. Six-panel decoration in which are Chinese domestic scenes, various ornaments, and symbols and palmations round shoulder and neck, all pencilled in two shades of fine cobalt blue underneath the glaze. Teakwood stand.

Height, $91 / 2$ inches.

879-OVIFORM JAR

Clear white porcelain. Decoration of flowers and leafy scroll in dark cobalt blue. Four-character mark of Chia-ch'ing. Teakwood stand.

Height, 81/2 inches.

880-QUADRILATERAL GOURD-SHAPED VASE

Clear white hard paste of the Chêng-hua period. Decoration of boating scenes, landscapes, ducks, plum-tree and inscription in brilliant underglaze blue. Capped with silver.

Height, 81/2 inches.

881-OVIFORM JAR

Clear white hard paste of the K'ang-hsi period. Finely painted decoration in brilliant underglaze blue of blossoms, basket of flowers, floral sprays and symbols of happy omen in variousshaped panels surrounded by scroll patterns. Teakwood stand. Height, $7 \frac{1}{2}$ inches.

882-BOTTLE FOR ROSE WATER

Clear white thick hard paste of the K'ang'hsi period. Decoration of various ornaments, scrolls, symbols of happy omen and floral sprays finely painted in underglaze blue of fine quality. Silver mounting. Teakwood stand.

Height, 12 inches.

883-SOFT PASTE DISH

Of exceedingly fine ivory white texture. Finely painted decoration of landscape, figures and mountain scenery in two shades of underglaze blue. Rim in imitation of iron rust.

Diameter, $8 \frac{1}{2}$ inches.

From the Brayton Ives Collection, Catalogue No. 10. 
Globular shape. White hard paste of the K'ang-hsi period. Decoration of the "Hundred Antiques," in brilliant underglaze blue. Teakwood stand.

Height, 41/2 inches.

885-BOTTLE-SHAPED VASE

White hard paste of the $K$ 'ang-hsi period. Decoration of various vases, symbols and flowers in brilliant cobalt blue. Teakwood stand.

Height, 101/2 inches.

886-OVIFORM JAR

Hard paste of clear white texture. Elaborate decoration of four five-clawed dragons amid cloud forms and fire emblems, band of wave designs round foot, and a narrow border of scrolls round the shoulder, all finely painted in two shades of cobalt blue underneath the glaze. Six-character mark of Yung Chêng. Has tall teakwood stand.

Diameter, $71 / 2$ inches.

88\%-LARGE COVERED BOX

Semi-globular shape. Hard paste of the K'ang-hsi period. Decorated with boldly drawn Chinese domestic and garden scenes, painted in brilliant underglaze blue. Double circle and leaf mark underneath the foot. Has teakwood stand.

Height, $5 \frac{1}{2}$ inches; diameter, $9 \frac{1}{2}$ inches.

888-BOTTLE-SHAPED VASE

White hard paste of the K'ang-hsi period. Decoration of flowering plants in two shades of blue within leaf-shape panels. Symbols and detached flowers round neck.

Height, 9 inches.

\section{9-LARGE GINGER JAR, WITH ORIGINAL COVER}

Clear white hard paste of the K'ang-hsi period. Decorated in fine underglaze blue, with floral pendants and shou symbol. Band of sceptre head scrolls round shoulder and wide border of gadroons round foot. Has teakwood stand.

Height, 10 inches; diameter, 8 inches.

890-LARGE GINGER JAR, WITH ORIGINAL COVER

Companion to the preceding.

Height, 10 inches; diameter, 8 inches. 
Of graceful shape and finished technique. Round the body is a finely painted decoration of branches of pomegranates, and round the shoulder and foot are broad bands of flowers and foliated scrolls with narrow borders of sceptre head scrolls and gadroons. The decoration throughout is in brilliant quality of underglaze blue and artistically executed. The vase is coated with a cream-white glaze which shows a large brown crackle. Ch'ien-lung period. Has carved teakwood stand.

Height, 141/2 inches.

892-GOURD-SHAPED VASE

Dense hard paste of the K'ang-hsi period. Numerous leaf-shape panels, which are modelled in low relief, are filled with figures, garden scenes and flowering plants, beautifully pencilled in underglaze blue of pure tint. Round the foot and upper lobe is a band of artichoke leaves modelled in low relief and outlined in blue. The mark underneath is a leaf in double circle in underglaze blue. Has teakwood stand.

Height, 16 inches.

893-SUPERB SOFT PASTE VASE

Of the Ch'ien-lung period. Graceful bottle shape and finished technique; invested with a pure white pellucid glaze of fine white quality; artistically pencilled in cobalt blue under the glaze with numerous conventional dragons amid an elaborate design of passion flowers and leafy scrolls which covers the entire body, and divided by a central band of incised lines of pale blue. Round the neck is a series of bands of pendants of conventional symbols surmounted by bands of palmettes. Has teakwood stand.

Height, 141/2 inches.

894-BOTTLE-SHAPED VASE

Hard paste of the K'ang-hsi period. Round the body is a decoration of branches of plum blossoms and bamboo in two shades of blue and in white reserve, and on the neck are branches of berries and symbolical pearl surrounded by clouds. A band of floriated and leafy scrolls encircles the shoulder. Has porcelain cap with European silver mounting. Teakwood stand. 
Clear white hard paste. Finely painted decoration in brilliant underglaze blue, illustrating the "Hundred Antiques" and Buddhistic symbols. Teakwood stand.

Height, 101/2 inches.

896-BLUE AND WHITE JAR

Clear white hard paste of the K'ang-hsi period. Finely painted decoration in brilliant underglaze blue of conventional scrolls of lotus with a symmetrical arrangement of large blossoms, which are fully expanded so as to display in each flower the cup-shape fruit, and shou mark. Brass handles on shoulder.

Height, 61/2 inches; diameter, 81/2 inches.

897-BLUE AND WHITE FLOWER POT

White hard paste of the Yung Chêng period. Decoration in rich underglaze blue: figure seated on fantastic animal underneath a willow tree.

$$
\text { Height, } 6 \text { inches; diameter, } 8 \text { inches. }
$$

898-OVIFORM FLOWER POT

Clear white hard paste of the $K^{\prime}$ ang-hsi period. Decoration in two panels of the "Hundred Antiques," pencilled in underglaze blue, and hawthorn blossoms and shou mark in white reserve on an opaque blue ground, with markings to resemble the cracking of ice. Teakwood stand.

$$
\text { Height, 63/4 inches; diameter, } 81 / 2 \text { inches. }
$$

\section{9-TALL OVIFORM VASE}

Clear white hard paste of the Ch'ien-lung period. Decorated in brilliant cobalt blue underneath the glaze with two boldly drawn four-clawed dragons rising from the sea and surrounded by fire emblems, pursuing the Pearl of Omnipotence. Round the shoulder is a narrow band of sceptre head scrolls. Has teakwood stand.

Height, 16 inches.

\section{0-BEAUTIFUL SOFT PASTE VASE}

Tall oviform of graceful shape. Invested with a pure white soft glaze of fine quality, and with a pear-skin surface and a network of minute pink crackle. The decoration, which is finely painted in brilliant opaque blue, depicts a mystic tiger standing on a rock beneath a pine tree, above which is a bold, four-clawed dragon amid cloud forms. Yung Chêng period. Has teakwood stand. 
Of graceful shape and finished technique. An extraordinary specimen from the Brayton Ives Collection and described in the catalogue of sale as follows:

Unique Vase of Ovoid Form.-Semi-eggshell texture and orange-peel surface; the decoration is blue on white; there is but a single painting upon the body of this vase, a noble lady standing beside a lion, which bears upon its back a vase and cover surrounded with flowers; the female figure carries in her left hand a wine gourd; around the rim of the vase is a key border in blue. The base has a repetition of this design. This vase is esteemed in this country as the chief of its class, and an analysis of the brush-work in the painting of the figure and beast would seem to confirm the high estimate which amateurs have accorded to its value. While the paste is soft and brilliant, no veins or crackle appear upon it. It is regarded as a matchless piece and belongs to the era of Yung-ching, 1723-1736. Has a teakwood stand.

Height, 16 inches; diameter, 71/2 inches.

From the Brayton Ives Collection, March, 1891, Catalogue No. 46.

902-BOTTLE-SHAPED VASE

Pure white hard paste of the Ch'ien-lung period. Orange-peel surface underneath a soft white glaze. Unusual decoration of writhing snakes painted in underglaze blue. Seal mark underneath foot.

Height, 11 inches.

903-BOTTLE-SHAPED VASE

With bulbous mouth. Dense hard paste. Decoration of garden scene, historical personages and symbols in rich underglaze blue. Teakwood stand.

Height, 111/2 inches.

904-BLUE AND WHITE ALTAR SET

Consisting of incense burner, two candlesticks and two vases. Dense white hard paste. Decoration of the "Hundred Antiques," Buddhistic symbols and floral designs in brilliant underglaze blue. Carved teakwood stand.

Average height, 121/2 inches.

\section{5-PILGRIM BOTTLE VASE}

Literally "Full Moon Vase." Pure white paste of the Ch'ien-lung period. Finely painted decoration, in cobalt blue, underneath the glaze, of pomegranate in bearing, the Sacred Fungi, sceptre heads and gadroons. Has teakwood stand.

From the Conte Krecskowsin Colnection.

Height, 121/4 inches. 
Clear white dense porcelain of the K'ang-hsi period. Archaic designs finely painted in underglaze blue of brilliant quality. Dragon-head handles on shoulder.

Height, 131/2 inches.

\section{0\%-TALL OVIFORM VASE}

Of thick white hard paste. The decoration, painted in underglaze blue, consists of garden and balcony scenes, equestrian and other figures, illustrating the departure of a Daimio and his attendants. Six-character mark of Chêng-hua. Has carved teakwood stand.

Height, 19 inches.

\section{8-BEAKER-SHAPED VASE}

White porcelain of the K'ang-hsi period. Decoration of branches of magnolia and other flowers pencilled in underglaze blue, the magnolias carved in low relief in the paste and in white reserve on a clouded brilliant blue ground. Rocks in low relief and coated with a celadon glaze. Teakwood stand.

Height, 17 inches.

909-BLUE AND WHITE PEAR-SHAPED VASE

'Thin white porcelain of the Ch'ien-lung period. Finely painted decoration of garden scene, palms, bamboo and tree peonies and various borders, all rendered in brilliant underglaze blue. Seal mark underneath foot. Carved teakwood stand.

Height, 14 inches.

\section{0-OVIFORM VASE}

With wide mouth and flaring base. Thick hard paste of the $K^{\prime}$ anghsi period. Decoration in brilliant underglaze blue, pine-tree, rocks, deer and storks, emblems of longevity.

Height, 13 inches.

\section{1-TALL CYLINDRICAL VASE}

White hard paste porcelain of the Yung Chêng period. Decoration of Chinese historical subject, palms and rocks painted in underglaze blue of fine quality. 
Sonorous hard paste of the K'ang-hsi period. The decoration of blooming plum artistically executed, the blossoms in white reserve delicately outlined on a background of brilliant opaque blue. Rocks and flowering plants painted in fine underglaze blue. Has carved teakwood stand.

Height, 18 inches.

913-TALL BEAKER-SHAPED VASE

Thick hard paste of the K'ang-hsi period. Decorated in underglaze blue with figures of dignitaries, attendants and garden scene; a central band of the Sacred Fungus amid an elaborate foliation. At the foot is a band of palmettes. Has teakwood stand.

Height, 18 inches.

\section{4-TALL OVIFORM VASE}

With wide mouth and flaring base. Clear white porcelain of the Ch'ien-lung period. Decorated in fine underglaze blue. Japanese legendary subjects in medallions, hawthorn blossoms on a stipple ground, and various borders and sceptre heads, gadroons and archaic designs. Teakwood stand.

Height, 161/2 inches.

\section{5-BOTTLE-SHAPED VASE}

Of clear white porcelain of semi-eggshell texture and finished technique. The body of the vase is of fine opaque blue, and has an elaborate embellishment of melon vine in bearing and butterflies executed in white reserve and outlined in blue. Round the shoulder and foot are borders of sceptre heads and gadroons, and a band of upright palmettes encircles the neck. K'ang-hsi period. 16621722.

Height, 171/2 inches.

916-OVIFORM VASE

Thin white porcelain of orange-peel surface. Decoration, painted in rich underglaze blue, depicts a Chinese garden scene, Chinese children playing a game and mandarin lady seated under a pine tree.

Height, 15 inches.

917-BEAKER-SHAPED VASE

Sonorous porcelain of the Yung Chêng period. Chinese historical subject, palms and rocks, painted in brilliant underglaze blue. 
Thick hard paste. Decoration of passion flowers amid an elaborate

foliation painted in underglaze blue. Teakwood stand.

Height, 181/2 inches.

919-BEAKER-SHAPED VASE

Clear white thin porcelain of the $K$ 'ang-hsi period. Decoration of mystic lions standing on rocks, turbulent water, cloud forms, fire emblems and Buddhistic symbols painted in brilliant underglaze blue. Ring and leaf mark underneath the foot. Teakwood stand. Height, 18 inches.

920-BLUE AND WHITE VASE

Tall, slender beaker shape. Hard paste of the K'ang-hsi period. Decoration of landscapes, river views and mountain scenery finely painted in underglaze blue of fine quality. Has teakwood stand.

Height, 19 inches.

\section{1-TALL OVIFORM JAR}

With original hat-shape cover. Clear white hard paste of K'anghsi period. Elaborate decoration of blooming tulips in jardinières, floral medallions and foliated scrolls beautifully painted in underglaze blue of brilliant quality. Various bands of sceptre heads and Greek fret. Has teakwood stand.

Height, 20 inches.

922-TALL OVIFORM VASE

Companion to the preceding.

923-BEAKER-SHAPED VASE

White hard paste of the $K^{\prime}$ ang-hsi period. Decorated in brilliant cobalt blue underneath the glaze. The ground is covered with a trellis design, and in eight leaf-shape panels are finely painted figures of the eight Taoist Genii. Carved teakwood stand.

Height, 171/2 inches.

\section{4-BEAUTIFUL OVIFORM VASE}

Clear white porcelain of semi-eggshell texture. The body of the vase is finely decorated with an elaborate design of melon vine in bearing upon a beautiful opaque blue ground. In two large, circular medallions are landscape, river view and mountain scenery pencilled in underglaze blue upon a white ground, and in two smaller medallions are conventionalized butterflies. A band of sceptre head scrolls round the shoulder and a wide band of gadroons surrounds the foot. The neck is encircled by upright palmettes. K'ang-hsi period. Has teakwood stand. 
925-LARGE BOTTLE-SHAPED VASE

Hard white paste of the $\mathbf{K}$ 'ang-hsi period. The entire surface is covered with a wave design painted in cobalt blue. A bold fourclawed dragon and the Pearl of Omnipotence surrounded by fire emblems are artistically carved in low relief in the paste and in white reserve.

Height, 181/2 inches.

926-LARGE BOTTLE-SHAPED VASE

Clear white hard paste of the K'ang-hsi period. Brilliant opaque blue ground, with a boldly drawn dragon pursuing the Sacred Pearl, and profuse cloud forms in white reserve and outlined in underglaze blue. Carved teakwood stand.

927-TALL OVIFORM VASE

Height, 19 inches.

Sonorous white porcelain of the Ch'ien-lung period. Decoration of storm dragon in white reserve and blue outlines. Cloud forms in powdered blue in brilliant quality. Carved teakwood stand.

Height, 201/8 inches.

928-LARGE BLUE AND WHITE VASE

Literally "Full-Moon Vase." Of graceful form and fine texture. It is decorated with large and small blossoms of the idealized flowers known as the flower of paradise, connected by a delicate wavy foliation. Two sceptre-shaped handles connect neck and shoulder. Ch'ien-lung period. Seal mark underneath the foct. Carved teakwood stand.

Height, 20 inches.

929-GRAND OVIFORM JAR

Clear white sonorous porcelain of the Chêng-hua period. Artistically pencilled in blue under a white glaze, which is strongly crackled, with an elaborate decoration of magnolia in bloom, tree peonies, rocks, pheasants and other designs, all beautifully rendered and painted in mazarine blue of exceedingly fine quality.

Height, 20 inches.

This extraordinary specimen is from the collection of the ComTE DE SEMILLE, member of the French Legation at Pekin, 1883.

930-TALL CLUB-SHAPED VASE

Clear white hard paste of the K'ang-hsi period. Elaborate decoration of magnolia in flower, tree peonies, birds of paradise, rocks and other designs beautifully painted in underglaze blue in brilliant quality. Carved teakwood stand.

Height, 281/2 inches. 
White hard paste of the K'ang-hsi period. Decoration of landscape, mountain and boating scenes, finely painted in brilliant underglaze blue; bands of sceptre-head and Greek fret encircling neck. Finely carved teakwood stand.

Height, 29 inches.

932-NOBLE BLUE AND WHITE PORCELAIN VASE

This noble specimen of the highest standard in Chinese decorative art was made in the Imperial potteries, and represents a scene of the Emperor and associates viewing an entertainment by the palace women in riding on ponies. The color is of the beautiful blue only found in the most delicate lapis lazuli, and is considered by the Chinese the finest example for comparison when selecting porcelains in blue and white. Finely carved teakwood stand.

Height, 2 feet $61 / 4$ inches; diameter, 11 inches.

From the looting of the Summer Palace, Pekin, 1860.

933-VERY LARGE BLUE AND WHITE VASE

Oviform body with bold trumpet-shape neck, on which are two dragon-shaped handles modelled in high relief. Of clear white porcelain of the Yung Chêng period. In two large panels are river views and mountain scenery pencilled in underglaze blue; the ground is of clouded opaque blue of brilliant quality, over which is an elaborate and finely painted decoration of flowers of paradise amid leafy scrolls, executed in white reserve and outlined with blue. Carved teakwood stand.

Height, 321/2 inches.

934-VERY LARGE BLUE AND WHITE VASE

Dense porcelain of the Ch'ien-lung period. Decoration of deer, pine and bamboo, rocks and cloud forms, in underglaze blue.

Height, 261/2 inches.

935-NOBLE BOTTLE-SHAPLD VASE

Sonorous porcelain of the Ch'ien-lung period. Elaborate decoration finely pencilled in blue outline underneath the glaze, consisting of a bold five-clawed dragon, Fêng-Huang bird, and the conventional lotus amid a profuse foliation.

Height, 28 inches.

From the Sichel Collection, 1882. 


\section{ANTIQUE CHINESE PORCELAIN DECORATED AND MONOCHROME SPECIMENS}

936-SMALL BOTTLE-SHAPED VASE

Invested with a glaze to imitate eggshell and profusely etched, with a decoration of kylin playing with a brocade ball and waving fillets painted in enamel colors. Seal mark in dark blue. Has carved teakwood stand.

Height, 53/4 inches.

987-SMALL OVIFORM VASE

Clear white porcelain of the Yung Chêng period. Exquisitely painted decoration of figures of Chinese sages, rocks, shrubs and the symbolical bat. Has carved teakwood stand.

\section{8-WRITER'S WATER JAR}

Height, 51/2 inches.

Clear white porcelain of the K'ang-hsi period. Decorated with branches of peony, delicately painted in peach bloom tint; green and purple enamels. The mark underneath, written in underglaze cobalt blue, consists of six characters of the $K^{\prime}$ ang-hsi period. Has carved teakwood stand.

Height, 31/2 inches.

939-CYLINDRICAL VASE OF SCROLL DESIGN

White hard paste porcelain of the Chia Ch'ing period. Coated with a yellow glaze and decorated with floral scrolls, conventional birds and winged dragons finely painted in bright enamel colors; a central band modelled in relief in brocade design in imitation of a tied presentation cloth. Interior coated with pistache green. Seal mark in blue. Has teakwood stand.

$$
\text { Height, 41/2 inches; diameter, } 4 \text { inches. }
$$

\section{0-OBLONG COVERED BOX}

White hard paste porcelain of the Chia-ch'ing period. Coated with a monochrome glaze of sea-green, over which is a decoration of floral scrolls and various Buddhistic symbols in brilliant enamel colors and gilding. Seal mark underneath.

Length, 61/2 inches; height, 3 inches.

From the Sichel Collection, 1882.

\section{1-SMALL OVIFORM VASE}

Thin white porcelain of the Ch'ien-lung period. Decorated with figure of Chinese sage and boy carrying plum branch beneath a rocky cliff, pencilled in delicate enamel colors. Has carved teakwood stand. 
White hard paste of the Ch'ien-lung period. Decoration of two five-clawed, horned dragons painted in coral red and enhanced by gilding and cloud forms in various enamel colors. Band round foot of wave design. Has teakwood stand.

Height, 73/4 inches; diameter, 63/4 inches.

\section{3-CHINESE PORCELAIN PATRA BOWL}

This sacred alms-bowl of Buddha is decorated in enamel colors with gilding.

It is a bowl of nearly globular form, rounding in at the side towards a circular mouth. It is painted with an out-door scene, with trees and rocks and palisades in the background, and a series of figures winding round in procession in the foreground. They are the eighteen Lohan, or Arhats, the principal disciples of Buddha, whose images line the walls of every Buddhist temple in China, each provided with its separate shrine and altar.

The first, beginning at the tree in the background and proceeding from right to left, is tearing open his breast to show the face of Buddha imprinted upon his heart from constant meditation thereon. The next is beating a small gilded bell which he holds in his other hand, mounted upon its handle of wood. The third carries a palm-leaf fan on his girdle; the fourth holds a yak's-tail fly-whisk. The fifth holds up a ritual hat, and the sixth a round jewel, with which he is luring a dragon from the clouds above, to carry him across the ocean. The seventh is clashing a pair of golden cymbals, vainly trying to arouse his companion, who is seated upon a rock in rapt contemplation, as if asleep, with a shoe on the ground beside him. The next holds up a manuscript book, his companion a relic shrine in the form of a dagaba. The eleventh is fondling his enormously elongated eyebrows, while the monk below him wields only a fly-whisk. The thirteenth, dressed in robes of purple brocade, carries a mitre-headed staff, following another, who holds up an open scroll. The fifteenth wields his fly-whisk in the air, and his companion holds a gilded alms-bowl, of the same form as the bowl before us. The next carries a scroll tied upon the crooked head of his pilgrim's staff, and the last holds up a gold bangle, bending over the form of a tiger, his own special attribute.

It is very doubtful if during the Ch'ien-lung period a piece could be found of more delicate execution and greater variety of colors. Although not of eggshell material, it is of the class of paintings placed upon those thin objects.

Since it has been mounted as an art object a beautiful perforated white jade cover has been placed upon it and furnished with an appropriate Chinese wooden stand.

Height, 53/4 inches; diameter, 51/2 inches. 


\section{4-PAIR OVIFORM JARS}

Hard paste of the Ch'ien-lung period. Coated with an eggshell glaze of etched surface and decorated with floral sprays and numerous borders finely painted in enamel colors. Seal mark pencilled in coral red underneath foot. Has teakwood stand.

Height, 81/2 inches.

\section{5-LOZENGE-SHAPED BOX AND COVER}

White hard paste of the Ch'ien-lung period. Coated with a green glaze and decorated with floral scrolls, archaic designs and symbol shou in bright enamel colors. On the cover is a band of lemonyellow. Seal mark in coral red underneath foot.

From the Sichel Collection, 188 .

Length, 81/2 inches; height, 23/4 inches.

\section{6-PRIEST'S CEREMONIAL SCEPTRE}

Finely modelled in porcelain. Coated with a turquoise-blue glaze and ornamented with flowers and leafy scrolls carved in low relief in the paste. Three panels are of openwork design and coated with a blue glaze and pencilled in gold. Bosses in imitation of jewels. Ch'ien-lung engraved seal mark.

Length, 20 inches.

\section{7-LOW VASE}

Melon-shape body, with bold, flaring neck. Invested with a monochrome glaze of orange tint. Round the shoulder and foot, carved in relief in the paste, are bands of sceptre heads in green and purple enamels. A wide band of upright palmettes encircles the neck, on which are two dragon handles, all enamelled in green. K'ang-hsi period.

From the Sichel Collection, 1882.

Height, $93 / 4$ inches.

\section{8-OVIFORM VASE}

Clear white porcelain of the Ch'ien-lung period. Invested with a fine red glaze, which darkens towards the foot. Has teakwood stand.

Height, 11 inches.

\section{9-WHITE PORCELAIN COVERED BOX}

Hard paste of the Ch'ien-lung period. Rough, unglazed outer surface, which is covered with an ornamentation of peony scrolls, shou mark, symbolical bat and cloud forms, which are carved in high relief and invested with a white pellucid glaze. Has high teakwood stand. 
Globular body with oviform neck, which is surmounted by a circular, jar-shape ornament. The porcelain is of clear white hard paste, of the Tao Kuang period. It is decorated round the body with beautiful painted flowers of paradise, foliations and the eight symbols of good fortune and happy omen, all painted in brilliant enamel colors. The neck is encircled by a band of inverted lotus leaves and glazed alternately in red, yellow and blue. The top ornament has a decoration of floral scrolls. Seal mark in red.

From the Sichel Collection.

Height, 101/2 inches.

951-BOTTLE-SHAPED VASE

Companion to the preceding.

From the Sichel Coliection.

952-BOTTLE-SH APED VASE

Of graceful shape. Clear white porcelain of the Tao Kuang period. Finely painted decoration, in enamel colors, of peach tree in bearing, the symbolical bat, rocks and wave design. Seal mark underneath foot. Carved teakwood stand.

Height, 12 inches.

\section{3-ANTIQUE CHINESE PORCELAIN VASE}

Bottle shape, with cup-shape mouth; clear white texture. Round the body and neck is a decoration of objects of art, floral sprays and symbols, some in white reserve outlined with bleu de Nankin, others finely painted in enamel colors. On two bands round the shoulder and lower lobe of neck are numerous symbols of happy omen. The whole on a rose-pink ground marked to resemble the cracking of ice, usually found in blue and white specimens. Ch'ienlung period. Has carved teakwood stand.

Height, 12 inches.

\section{4-PURE WHITE PORCELAIN VASE}

Bottle shape, with a broad flange round mouth of sceptre head design. The surface of body is covered with a beautifully carved decoration of peony scrolls. Round the shoulder is a band of sceptre head scrolls and a broad band of upright palmations encircling the neck. Ch'ien-lung period. Carved teakwood stand. 
Hard paste porcelain of the Ch'ien-lung period. Invested with a monochrome glaze of deep turquoise tint of rich translucence and minutely crackled.

From the Sichel Collection, 1882.

Height, 12 inches.

\section{6-CHINESE PORCELAIN ALTAR ORNAMENT}

The figure of an elephant elaborately decorated with enamel colors of the Ch'ien-lung period. The tusks are of real ivory. The saddle-cloth is decorated with symbols of good fortune and long life, obtuse-angled musical stones hung with fillets, and bats flying in the clouds, above a floor of rocks and curling sea-waves. This is thrown over another of floral design in red and gold, ending in strings of beads and golden balls.

Upon the peaked saddle is perched a beaker-shaped vase painted in red and gold with the hundred different forms of the longevity character, and gilded round the rim. Finely carved teakwood stand.

$$
\text { Height, 121/2 inches; length, } 10 \text { inches. }
$$

\section{7-BOTTLE-SHAPED VASE}

With bulbous mouth. Thick porcelain of the Ch'ien-lung period. Invested with a monochrome glaze in brilliant red of the sang-debœuf type. Teakwood stand.

From the Sicher Collection, 1882.

Height, 13 inches.

\section{8-TALL OCTAGONAL VASE}

Clear white porcelain of the Ch'ien-lung period. Invested with a coral red glaze of fine quality, over which is a slight decoration pencilled in gold. In four upright panels are landscapes and inscriptions, boating scenes, pine tree and rocks painted in enamel colors and in India ink. Seal mark in blue underneath foot. Carved teakwood stand.

Height, 13 inches.

959-LARGE JAR

Oviform. Clear white porcelain. Elaborately decorated in brilliant enamel colors, in the style of the $\mathbf{K}$ 'ang-hsi famille verte. On the body of the vase is a Chinese garden scene and numerous figures of ladies and children. Round the neck are various symbols of happy omen. K'ang-hsi. 1662-1722. Has carved teakwood stand. 
Companion to the preceding. (Repaired.)

161-GALIPOT

Of graceful form and fine technique. Thin white hard paste of the Yung Chêng period. Invested with a pale green translucent glaze over which is a beautiful decoration of tree peonies, and branches of berries, executed in delicate colors of pink, yellow, green, white and other enamels. Teakwood stand.

Height, 1.41/4 inches.

962-UNIQUE VASE

Quadrangular trumpet-shaped. Clear white porcelain of the $\mathrm{K}$ 'ang-hsi period. On a ground of dense black is a finely painted decoration of branches of coral berries and green leaves. Round the base is a leaf-border of turquoise-blue on black. The edges of vase are rimmed with pure white. Has carved teakwood stand. Height, 12 inches; diameter, 5 inches.

From the Brayton Ives Collection, 1891, Catalogue No. 153.

963-GRACEFUL BOTTLE-SHAPED VASE

Oviform body with tall, tubular neck. Clear white porcelain of the Chia-ch'ing period. Elaborate and finely painted decoration of branches of peonies, five-clawed dragon, Fêng-Huang and cloud forms, all rendered in brilliant enamel colors. Seal mark underneath the foot. Carved teakwood stand.

Height, 15 inches.

964-OVIFORM VASE

White hard paste of the Yung Chêng period. Decoration of a figure of mandarin and two females richly costumed, illustrating a Chinese historical subject, finely painted in fine enamel colors. On the neck are symbols of longevity. Has carved teakwood stand.

Height, 151/2 inches.

\section{5-GALIPOT}

Clear white porcelain of the $\mathbf{K}$ 'ang-hsi period. Decoration of floral and leafy scrolls and winged dragons, finely pencilled in underglaze blue and rouge de cuivre tint.

From the Sichel Sale, 1882. 
Dense porcelain of the Ch'ien-lung period. Covered with a monochrome glaze of brilliant red, which is mottled and finely crackled. Inner surface of the mouth of the vase is enamelled with a "rice color" crackled glaze. Carved teakwood stand.

Height, 16 inches.

\section{7-CYLINDRICAL VASE}

White hard paste. Decoration of floral sprays and butterflies, painted in brilliant enamel colors on a ground of conventional rings.

From the Sichel Coliection, 1882.

Height, 16 inches.

\section{8-OVIFORM VASE}

With tall cylindrical neck and spreading base. Clear white hard paste of the K'ang-hsi period. On the body of the vase are bold sceptre heads of sea-green, outlined with black and red. The decoration of floral and leafy scrolls is in white reserve and outlined with black. Various borders and palmettes are in brilliant green and coral red, with blossoms and floral scrolls in white reserve. Has teakwood stand.

Height, 151/2 inches.

\section{9-IMPERIAL CH'IEN-LUNG VASE}

Graceful bottle shape, with sceptre-shaped handles and pendants of Svastski symbol and tassels on neck. Clear white hard paste. Decoration of magnolia and plum trees in bloom and tree peonies, beautifully painted in brilliant enamel colors. Underneath, the foot is invested with a green enamel and marked with a seal in coral red. Carved teakwood stand.

From the Sichel Collection, 1882.

Height, 151/2 inches.

\section{0-TALL CYLINDRICAL VASE}

White hard paste of the $K^{\prime}$ 'ang-hsi period. Painted in brilliant enamel colors, with Chinese domestic scene, boating parties gathering lotuses, willow and pine tree. On the neck is a seated pilgrim, gourd and rocks. Carved teakwood stand.

From the Sichel Collection, 1882. 
White porcelain of the Yung Chêng period. Decorated in fine mazarine blue and peach-bloom tint, underneath the glaze, with a large peach tree bearing fruit and blossoms. On the reverse, two bats, symbols of happiness. Seal mark underneath the foot.

From the Sichel Collection.

Height, 151/2 inches.

\section{2-BOTTLE-SHAPED VASE}

Of graceful form. White hard paste, covered with a soft ivorywhite glaze. On the body is a decoration of flowers of paradise and foliation carved in the paste in low relief and beautifully enamelled in various colors. Round foot and shoulder are bands of sceptre heads on an imperial yellow ground, and a wide band of upright palmations and various symbols encircle the neck, all of which are carved in low relief in the paste and painted in brilliant enamel colors. Ch'ien-lung incised seal mark underneath the foot.

973-GOURD-SHAPED VASE

Gracefully fashioned. Of white hard paste and richly decorated in brilliant enamel colors. The lobes are ornamented with sceptre head scrolls, chrysanthemums, lotus and foliations. On the upper lobe, in addition to this decoration, is the Svastski symbol and inscriptions. The waist is belted with diaper, arabesques and medallions of Buddhistic symbols, and the foot and neck encircled with conventional gadroons and conventional arabesques. Carved teakwood stand.

Height, 181/2 inches.

\section{4-CLUB-SHAPED VASE}

Clear white hard paste. Painted in the brilliant enamel colors of style of the K'ang-hsi famille verte. The body is decorated with a group of mounted and unmounted warriors, rocks, pine and willow trees and other designs, the scene illustrating a Chinese historical subject. Round the shoulder is a band of mosaic design and chrysanthemum crests, and on the neck a decoration of trees and rocks. Has teakwood stand. 
Thick hard paste porcelain of the K'ang-hsi period. Invested with a pale celadon glaze and decorated with chrysanthemums, plum blossoms, bamboo branches and butterflies painted in neutral tints and rouge de fer over a pronounced crackled surface, which is marked by brown lines.

Height, $173 / 4$ inches.

\section{6-TALL GOURD-SHAPED VASE}

Clear white hard paste porcelain of the Kea-tsing period. It is invested with a monochrome glaze of lemon-yellow, and profusely decorated with gourds and vines finely painted in underglaze blue of brilliant quality. Six-character mark underneath the foot.

$$
\text { Height, 181/2 inches; diameter, } 91 / 2 \text { inches. }
$$

From the Brayton Ives Collection, 1891, Catalogue No. 145.

\section{7-SUPERB VASE}

Clear white porcelain of the K'ang-hsi period. This vase has a pure white translucent ground, and is enamelled with the brilliant colors of Chinese ceramic art, bright emerald green predominating, so that it forms a remarkably fine example of the famille verte. The decoration represents rocks and tall pines arising in the background, which form an ornamental frame for the scene with which the vase is decorated. This is an imperial procession, the central figure being the emperor, mounted on horseback, followed by two ladies in brocade robes, riding abreast; two men follow holding swords mounted upon poles, and a green-robed figure walks at the side, carrying a large umbrella. The procession is headed by two lictors with poles, followed by two men carrying imperial banner screens. Two mail-clad figures with swords at their sides, wearing plumed helmets, walk immediately in front of the emperor carrying standards; just before them are two strangers apparently interrupting the procession, one with grotesque features and savage mien, having a necklace tied loosely about his neck. It is doubtless a scene taken from some historical play.

Height, 18 inches; diameter, 9 inches.

From the R. Austin Robertson Collection, 1883. 
Clear white porcelain of the K'ang-hsi period. Coated with a monochrome glaze of apple-green color, which is stippled with black. On the body of vase are several white ground panels of leaf and peach shape, within which is an embellishment of flowers, grotesque animals, and other designs, painted in enamel colors. Round the foot is a band of mosaic designs and medallions of tigers and lions, and on the neck, painted in orange and blue, the "Shou" symbol of longevity. Teakwood stand.

Height, 17 inches; liameter, 8 inches.

From the Brayton Ives Collecrion, 1891, Catalogue No. 95.

979-GRAND OVIFORM VASE

With two rudimentary handles on neck. The vase is of dense sonorous porcelain, and beautifully decorated in brilliant enamel colors of the Yung Chêng period. The decoration consists of tree peonies (emblem of riches and rank) in full bloom, birds and rocks. Carved teakwood stand.

Height, 19 inches.

\section{0-TALL OVIFORM VASE}

White hard paste of the K'ang-hsi period. Painted in brilliant enamel colors of the famille verte; the body is decorated with a group of figures, which represents the Triad of the Taoist cult, Fu Lu Shou San Hsing, or "The three star gods of Happiness, Rank and Longevity," a deer, tall pine tree and rock rising in the background. Round the shoulder is a wide band of diaper ornament, broken by four medallions which contain Taoist symbols. On the neck is a decoration of bamboo, rock and fungus. (Rim slightly chipped.) Teakwood stand.

Height, 173/4 inches.

\section{1-PILGRIM BOTTLE VASE}

Of the Ch'ien-lung period. Literally "Full Moon" vase of graceful form and exceedingly fine texture. It is covered with a pellucid glaze and decorated with five-clawed, two-horned dragon; on the obverse and reverse side of the vase, rising from the waves of the sea amid cloud forms and fire emblems and surrounded by numerous bats, symbols of happiness, all finely painted in polychrome enamels and touched with gold. Seal mark underneath foot pencilled in cobalt blue. Carved teakwood stand. 
Of graceful shape. Clear white hard paste. Invested with a bluewhite glaze and richly decorated with the most brilliant enamel colors of the Ch'ien-lung period. The decoration consists of a group of figures which represent the Triad of the Taoist cult, $F u$ Lu Shou San Hsing, or "The three star gods of Happiness, Rank and Longevity," the other smaller figures being attendant sprites. Lu Hsing has the place of honor in the middle, clad in imperial robes and holds a baton of rank; on his left is Shou Hsing, the "Divinity of longevity." On his right stand Fu Hsing, the personified "Star of Happiness." In the background are pine trees and rocks. Finely carved teakwood stand.

From the Sichel Colnection.

II eight, 20 inches.

\section{3-IMPERIAL CH'IEN LUNG VASE}

Graceful bottle shape. Clear white hard paste. Profusely decorated in brilliant enamel colors with flowers of paradise, peony, the "Mandarin's flowers," floral sprays of lotus, chrysanthemum and begonia, interspersed with numerous conventional dragons. The ornamentation is completed by borders of gadroons and Greek fret round the foot, and bands of sceptre heads and Greek fret encircling the shoulder and neck. On the neck are two handles of sceptre design enamelled in coral red. Seal mark underneath the foot pencilled in blue. Carved teakwood stand.

From the Summer Palace at Tekin, 1860.

Height, 21 inches.

From the Sichel Colifecion, New York, 188?.

984-GRAND BOTTLE-SHAPED VASE

Globular body with tall cylindrical neck. Clear, sonorous porcelain of the Ch'ien-lung period. Invested with a monochrome glaze of opaque blue, and elaborately ornamented, with numerous figures of kylins, playing with brocade balls with waving fillets, carved in low relief in the paste and decorated with rouge de fer and underglaze blue. Round the foot is a band of gadroons, and the neck is encircled with a band of sceptre head scrolls. Carved teakwood stand.

Height, 233/4 inches.

\section{5-TALL OVIFORM VASE}

Thick hard paste porcelain of the Ch'ien-lung period. Enameled with a red glaze of Lang Yao type. The upper edge of the neck is defined by a rim of white. The foot underneath is glazed. Carved teakwood stand. 
Oviform body with tall tubular neck. Richly and profusely decorated in brilliant enamel colors of the Ch'ien-lung period on a ground of sea-green monochrome glaze. The decoration consists of flowers of paradise and elaborate foliations interspersed with the bat, emblem of happiness, and the Svastski symbol. Round the foot is a band of gadroons and palmettes, sceptre heads and Greek fret, and around the shoulder a wide band of upright palmettes; sceptre head scrolls encircle the neck. Seal mark underneath the foot pencilled in vermilion. Teakwood stand.

Height, 25 inches.

987-IMPERIAL CH'IEN-LUNG VASE

Tall oviform shape, with tubular neck and spreading mouth and dragon handles. Clear white sonorous porcelain. The body of the vase is decorated with a beautifully painted decoration illustrative of the Chinese festival of the dragon, mountain and landscape scenery. The shoulder and neck are invested with a monochrome glaze of brilliant green and richly decorated with floral scrolls and various symbols of happy omen. Borders and bands of foliations, sceptre heads, gadroons and Greek fret. Carved teakwood stand.

Height, 311/2 inches.

\section{8-CHINESE IMPERIAL VASE}

Dense, sonorous porcelain of the Ch'ien-lung period. The decoration is in enamel colors of green, yellow, red and purple shades, in combination with cobalt blue, painted under a glaze in the tone and manner of the earlier part of the Ch'ien-lung era. The "camellia" green has become iridescent. The vase itself is decorated with an imperial dragon and phœnix displayed upon a floral background. The five-clawed dragon of usual form stretches out its huge, monstrous head in the middle of the vase, which it completely embraces with its scaly serpentine body, reaching up with its coils almost to the top. The phœnix is displayed with outspread wings and spreading tail grasping one of the floral branches with its two feet. The profuse floral background is composed of undulating sprays of the idolized manifold forms of the Indian lotus (Hsi Fan Lien). Has an elaborate teakwood stand with an inserted panel of jade, which is ornamented with a dragon and a phonix carved in low relief.

Height, 33 inches; diameter, $\mathrm{j7} \% \mathrm{8}$ inches.

From the Sichel Collection, 1882. 
Oviform body with tubular neck, spreading at mouth. Dense porcelain of the Ch'ien-lung period. Coated with a monochrome glaze of tea color and profusely ornamented with four-clawed dragons, cloud forms, fire emblems and the "Sacred Pearl," carved in high relief in the paste and decorated in copper red and underglaze blue. Two dragon handles on neck.

Height, 32 inches.

\section{0-PAIR LARGE IMPERIAL CHINESE VASES}

Noble bottle-shaped with covers. Clear white hard paste of the Yung Chêng period. The background is of a monochrome celadon glaze of pure color and rich lustre. The floral decoration, which spreads all over the surface of the vase, consists mainly of the grape vine with fruit; the leaves are in blue, red and plain green, with hanging bunches of blue, crimson and gilded grapes; there will also be found a squirrel and butterfly, a frequent combination in Chinese art; also a trellis work of tendrils in crimson and gold. Yellow is the only enamel color of the "famille rose" not represented, excepting in the petals of the flowers which fill in all the interstices between the curling tendrils of the vine. The squirrels are enamelled red or crimson and touched with gold. The butterflies which are found all over the vase are of the gayest tints. The other flowers mentioned are peonies, carnations, convolvulus, rose, rose mallow, chrysanthemums, orchids, dielytra, peach and plum blossoms.

Height, 36 inches; diameter, 153/4 inches.

From the looting of the Summer Palace at Pekin, 1860.

From the Hamilton Palace Collection.

991-GRAND CHINESE IMPERIAL SCREEN

Composed of six upright panels mounted on an elaborate base of carved teakwood. Inserted in the panels is a series of eighteen beautifully decorated porcelain plaques. The central plaques of upright shape depict famous palaces, landscapes and mountain scenery of ancient China, painted in enamel colors of the verte famille of the K'ang-hsi period; the plaques forming the upper border are square-shaped, and embellished with figures of the Taoist cult and their attendants executed in delicately blended enamel colors of the Yung Chêng period; and those forming the lower border, also of square shape, are decorated with the "blos- 
soms and flowers of the seasons" exquisitely painted in delicate enamel colors of the Yung Chêng period. The intervening spaces are filled with teakwood carvings of archaic designs. Has two extra panels with base.

\author{
Length, 8 feet; height, 6 feet.
}

The above extraordinary specimen is said to have been looted from the Summer Palace at Pekin, 1860.

\title{
992-DECORATED PORCELAIN STATUETTE
}

Seated Buddha, holding a vase decorated in brilliant enamel colors on porcelain stand of lotus design.

II eight, 20 inches.

Brought from the Summer Palace at Pekin, 1860, by a French officer. From the Sichel Coliection, New York, 1882.

\section{2a-DECORATED BOWL}

Clear white porcelain of the Tao-Kuang period. Engraved lemon-yellow ground with floral scrolls in bright enamel colors. Landscape, river and mountain scenery in four medallions. Seal mark underneath the foot.

Diameter, 6 inches.

993-DECORATED BOWL

Clear white porcelain of the Tao-Kuang period. Engraved rose-color ground with floral scrolls in various enamels. Four white medallions containing numerous ornaments and symbols. Seal mark underneath the foot.

Diameter, 6 inches.

994-DECORATED BOWL

Clear white porcelain of the Tao-Kuang period. Engraved pink ground of floral scrolls in colors and the medallions of flowering plants delicately painted. Seal mark under the foot.

Diameter, 6 inches.

995-DECORATED BOWL

Clear white porcelain of the Tao-Kuang period. Floral medallions delicately painted in enamel colors; symbols on an engraved yellow ground. Seal mark in blue.

996-TWO BOWLS

Diameter, 6 inches.

White hard paste of the Tao-Kuang period. Five-clawed dragons, Fêng-Huang birds and floral sprays painted in brilliant enamel colors. 
White hard paste of the Tao-Kuang period. Decoration of passion flowers and foliation finely painted in enamel colors on a yellow ground. Seal mark in blue.

$$
\text { Diameter, 71/2 inches. }
$$

\section{8-MONGOLIAN BOWL}

Clear white hard paste. Decorated with various Buddhistic symbols, inscriptions and other designs in brilliant enamel colors and gilding.

$$
\text { Diameter, 61/2 inches. }
$$

\section{9-MONGOLIAN PLATE}

To match the preceding.

$$
\text { Diameter, } 9 \frac{1}{2} \text { inches. }
$$

\section{0-LARGE BOWL}

White hard paste of the Chia-Ch'ing period. Engraved surface of the wave designs, with figures of deities painted in bright enamel colors. Seal mark underneath the foot.

$$
\text { Diameter, 61/2 inches. }
$$

1001-BOWL

White hard paste of the Tao-Kuang period. Coral red glaze. Floral scrolls in white reserve and outlined with red. Seal mark underneath foot.

$$
\text { Diameter, } 5 \text { inches. }
$$

\section{2-TWO BOWLS}

White hard paste of the Tao-Kuang period. Outer surface covered with a brilliant green glaze and decorated with five-clawed dragons, fire emblems and cloud forms incised and enamelled with purple. Seal mark pencilled in blue.

Diameter, $4 \frac{1}{2}$ inches.

\section{3-DECORATED BOWL}

Clear white porcelain of the Tao-Kuang period. Buddhistic symbols of happy omen and various borders painted in brilliant enamel colors.

Diameter, $4 \frac{1}{2}$ inches.

1004-PAIR BOWLS

Clear white porcelain of the Ch'ien-lung period. Decoration of vines, pomegranates and bamboo branches in fine enamel colors. Seal mark underneath the foot. 
Pure white hard paste. Fine coral-red glaze with wave designs in white reserve. Six-character mark of Yung Chêng underneath the foot.

Diameter, 31/2 inches.

1006-PLATE

Chinese porcelain of thin texture. Unusual decoration in Italian style. "Birth of Christ" painted in sepia.

Diameter, 9 inches.

\section{0\%-ANTIQUE CHINESE PORCELAIN PLAQUE}

Clear white texture. Exquisitely painted decoration of tree peony in bloom, pheasant on branch, and rocks executed in fine enamel colors. Yung Chêng period. Framed in carved teakwood.

Diameter, 11 inches.

\section{8-ANTIQUE CHINESE PORCELAIN PLAQUE}

Clear white texture. Exquisitely painted decoration of plum tree in blossom, pine, sparrows and rocks in finely combined enamel colors. Yung Chêng period. Framed in carved teakwood.

Diameter, 11 inches.

\section{9-LARGE PLAQUE}

Deep circular shape. Clear white texture. Decoration of phœnix and rocks finely painted in enamel colors in centre panel. Border of bold sceptre heads in black with decoration of chrysanthemum flowers and leafy scrolls in pink, white, yellow and green enamel colors. K'ang-hsi period.

Diameter, 22 inches.

\section{0-ANTIQUE COCHIN CHINESE PLATE}

Landscape and waterfall modelled in relief in centre panel and enamelled in yellow, brown and green. Border of symbols and ornaments carved in high relief and covered with a fine old green glaze. Scalloped edge. (Neatly repaired.)

Diameter, 17 inches.

\section{1-LARGE PLAQUE}

Sonorous porcelain of the Yung Chêng period. Decorated on both sides with branches of peach tree bearing blossoms and ripe fruit painted in fine enamel colors. Six-character mark within circle underneath the foot. 
Old Chinese dense porcelain of the Ming period. Coated with a sea-green glaze of fine quality. Decoration of peony scrolls and a wide band of upright palmettes carved in the paste in high relief. Around the foot is a network of brown crackle.

Height, 151/2 inches.

1013-LARGE, GRACEFUL BOTTLE-SHAPED VASE

Of lotus design. Clear white porcelain of the Ch'ien-lung period. Covered all over with a pellucid glaze of pale celadon color. Seal mark pencilled in blue underneath the foot.

Height, 21 inches.

\section{4-LARGE CELADON VASE}

Globular bottle-shaped, with tall cylindrical neck on which are two tubular handles. Dense, sonorous porcelain of the Ch'ien-lung period. Invested with a celadon glaze of sea-green tint, varying in tone so as to bring out the decorative details underneath. This decoration consists of an elaborate design of flowers of paradise amid foliations, and a series of bands of palmettes and fret, gadroons and sceptre head scrolls.

Height, 25 inches.

1015--TALL CELADON VASE

Oviform body with bold, spreading neck. Of dense porcelain of the Ming period, and invested with a celadon monochrome glaze of sea-green tint over a brown crackled surface. Rimmed with metal.

Height, 321/2 inches.

1016-LARGE CHINESE FISH BOWL

Dense hard paste porcelain. Rich embellishment on the outer surface of birds of paradise, tree peonies, mandarin ducks and other designs painted in brilliant enamel colors of famille rose. On the inner surface is a decoration of fishes. Two handles of grotesque mask design modelled in high relief.

$$
\text { Height, 151/2 inches; diameter, 241/2 inches. }
$$

From the Sichel Collection, 1889.

\section{7-LARGE PUNCH BOWL}

Chinese hard paste. Decoration of domestic and garden scenes, flowers and butterflies painted in brilliant enamel colors and enhanced by gilding. 
1018-PAIR CHINESE GARDEN SEATS

Hexagonal shape. Dense hard paste. Richly painted decoration of Chinese domestic and garden scenes painted in bright enamel colors and enriched by gilding.

1019-PAIR HEXAGONAL GARDEN SEATS

Height, 181/2 inches.

Chinese porcelain. Celadon glaze with ornamentation in white pâte sur pâte.

Height, 181/2 inches.

1020-LARGE PLANT JAR

Chinese porcelain of heavy texture. Decoration of dragons, tree peonies and various borders in cobalt blue.

Height, 19 inches; diameter, 21 inches.

1021-LARGE PLANT JAR

Similar to the preceding.

1022-LARGE PLANT JAR

Similar to the preceding.

1023-MAMMOTH PLANT JAR

Chinese porcelain of dense texture. Decorated in bleu de Nankin, with bold dragons, tree peonies and gadroon and sceptre head borders. Lined with metal.

Height, 23 inches; diameter, 28 inches.

\section{JAPANESE PORCELAINS AND POTTERY}

1025-PAIR JAPANESE OKIMONOS

Mandarin ducks. Modelled in Hirado porcelain and coated with

a pellucid white glaze.

1026-LIBATION CUP.

Old Kioto faience, fashioned after and decorated in imitation of a Ming specimen.

102\%-PORCELAIN JAR

Ivory-white texture. Branches of plum blossoms carved in high relief. Mounted in silver. 
Clear white porcelain of soft paste type. Decoration of chrysanthemums, bamboo and butterflies, carved in the paste in low relief underneath a soft cream-white glaze. Teakwood stand.

Height, 41/2 inches.

1029-OLD JAPANESE PORCELAIN OKIMONO

Monkey holding a peach-shaped dish, the latter coated with red lacquer.

1030-JAPANESE CELADON FIRE BOWL

Circular-shaped on tripod. Ornamented with peony scrolls carved in the paste in high relief, underneath an opaque sea-green glaze. Silver cover of bamboo designs in openwork.

Height, $4 \frac{1}{2}$ inches; diameter, $5 \frac{1}{2}$ inches.

1031-OLD IMARI PORCELAIN BOX

Design of a Nō dancer's mask. Blue and white decoration.

Height, 31/2 inches; length, 7 inches.

1032-HIRADO JAR

Quadrilateral oviform. Clear white hard paste, with a decoration of bamboo branch painted in fine underglaze blue. Teakwood stand.

Height, 71/2 inches; diameter, 6 inches.

1033-HIRADO RICE JAR

Pure white hard paste. Sprays of peonies carved in the paste in low relief under a pellucid white glaze. Around the foot and shoulder is a band of carved basket pattern. Teakwood lid surmounted by a carved white jade ornament.

Height, 7 inches; diameter, 6 inches.

1034-HIRADO JAR

Cylindrical-shaped. Pure white hard paste. Decoration of flowers of paradise amid foliations, bamboo and grasses finely painted in brilliant underglaze blue. Teakwood lid with carved ornament.

$$
\text { Height, } 8 \text { inches; diameter, } 6 \text { inches. }
$$

1085-IVORY WHITE PORCELAIN KORO

Japanese. Globular shape; on tripod, with two rudimentary handles on shoulder. Ornamentation of numerous dragons modelled in relief. Silver mountings and lid.

Height, 8 inches; diameter, 6 inches. 
Satsuma faience. Finely painted decoration of floral medallions on a gold band. On the cover flying storks in white and black on a ground covered with gold dots.

Diameter, 6 inches.

1037-GOURD-SHAPED VASE

Old Japanese porcelain. Decoration of chrysanthemum flowers modelled in low relief and decorated with cobalt blue, coral red and green enamels; brown crackle glaze. Has carved teakwood stand.

IIeight, 12 inches.

1038-OLD BANKO TEAPOT

Ramboo design. Gilded metal mountings.

1039-BOCCARO POTTERY BOWL

Red texture. Ornamentation of dragon medallions carved in high relief; around the rim a band of Mongolian characters. Seal mark underneath foot.

Diameter, 71/2 inches.

1040-LARGE ANTIQUE JAPANESE POTTERY PLAQUE

Dense texture. Carved and glazed in imitation of Soo-Chow lacquer. Ornamented with a group of seven masks and coated with various lacquers.

Diameter, 18 inches.

1041-OLD JAPANESE POTTERY STATUETTE

A standing figure of a priest in a flowing robe. Coated with a fine iridescent green glaze.

Height, 16 inches.

1042-OLD POTTERY STATUETTE

A Chinese dignitary in a long robe, in standing posture with right arm uplifted. Invested with a red glaze, with tracery in gilding. Teakwood stand.

Height, 23 inches.

1043-LARGE OVIFORM JAR

Dense porcelain, coated with a monochrome glaze of pearl gray. Elaborate ornamentation of tree in bloom, and bird carved in high relief in the paste and covered with a cream-white, soft glaze. Character mark underneath foot.

Height, 30 inches; diameter, 18 inches. 
1044-JAPANESE PORCELAIN VASE

By Makudza Kozan. Coated with a rich, dark-blue glaze and decorated with an artistically painted goose. Teakwood stand.

IIeight, 12 inches.

1045-GOURD-SHAPED VASE

Satsuma faience. Artistically decorated with a Japanese subject known as the "Thousand Storks." Brocade designs round neck. Height, 12 inches.

1046-JAPANESE STATUETTE

Figure of Jim-mu-tennō, the first Emperor of Japan. Artistically modelled in pottery and coated with a gray glaze.

Height, 24 inches.

1047-LARGE JAPANESE OKIMONO

Dog Foo. Modelled in dense pottery and coated with a monochrome opaque glaze.

Height, 20 inches; length, 21 inches.

\section{CHINESE TEAKWOOD TABLES AND S'TANDS}

1049-TALL TEAKWOOD STAND

Carved ornamentation.

Height, 20 inches; diameter, 18 inches.

1050-TWO TALL PEDESTALS

Chinese carved teakwood, and India marble panels inserted in tops.

Height, 39 inches.

1051-PAIR CIIINESE TEAKWOOD HALL SEATS

Barrel-shaped. Elaborately carved in openwork; India marble panels inserted in top.

Height, 21 inches.

1052-PAIR HALL SEATS

Chinese teakwood. Barrel-shaped, of carved openwork design inlaid with mother-of-pearl. Marble panels inserted in tops.

1053-PAIR HALL SEATS

Similar to the preceding.

1054-HALL SEAT

Similar to the preceding. 
1055-SIX TEAKWOOD VASE STANDS

Assorted sizes.

1056-FIVE TEAKWOOD STANDS

Assorted sizes.

105\%-THREE TEAKWOOD STANDS

1058-TWO TEAKWOOD STANDS

1059-THREE TEAKWOOD STANDS

1060-TWELVE SMALL TEAKWOOD STANDS

1061-SEVEN TEAKWOOD STANDS

Odd shapes.

1062-THREE TEAKWOOD STANDS

1063-FOUR TEAKWOOD STANDS

1064-PAIR OF TEAKWOOD STANDS

1065-PAIR OF TEAKWOOD STANDS

1066-FOUR TEAKWOOD STANDS

Assorted sizes.

106\%—TWO TEAKWOOD STANDS

1068-TWO TEAKWOOD STANDS

1069-SIX TEAKWOOD STANDS

1070-THREE LARGE TEAKWOOD STANDS AND ONE COVER

1071-FINELY CARVED TEAKWOOD STAND

1012-TWENTY-FOUR SMALL TEAKWOOD S'TANDS

1073-FIVE TEAKWOOD.COVERS

1074-TWELVE SIALL TEAKWOOD STANDS

Assorted sizes.

1075-FOUR STANDS

Assorted shapes and sizes. One has marble top. 
10^6-ONE FINELY CARVED TEAKWOOD S'IAND

10\%7-FIVE TEAKWOOD STANDS

1078-FOUR TEAKWOOD STANDS

Assorted sizes.

1079-FOUR TEAKWOOD STANDS

Assorted sizes.

1080-FIVE TEAKWOOD STANDS

Assorted sizes.

1081-THREE TEAKWOOD STANDS

1082-FOUR TEAKWOOD STANDS

Assorted sizes.

1083-TWELVE SMALL TEAKWOOD STANISS

1084-TWENTY-FOUR TEAKWOOD STANDS

Odd shapes.

1085-SIX TEAKWOOD STANDS

Odd shapes.

1086-TWO TEAKWOOD STANDS

One with porcelain top.

108\%—FOUR TEAKWOOD STANDS

1088-TWO TEAKWOOD STANDS

1089-TWO TEAKWOOD STANDS

1090-PAIR OF TEAKWOOD STANDS

1091-THREE TEAKWOOD STANDS

1092-THREE TEAKWOOD STANDS

1093-TWO TEAKWOOD STANDS

1094-TWO TEAKWOOD STANDS

1095-THREE TEAKWOOD STANDS

Odd shapes. 
1096-SIX TEAKWOOD STANDS

Assorted sizes.

1097-FIVE TEAKWOOD STANDS

Various shapes.

1098-TWENTY-THREE TEAKWOOD STANDS

Odd shapes.

1099-THIRTEEN TEAKWOOD STANDS

Odd shapes.

1100-EIGHT TEAKWOOD STANDS

Odd shapes.

1101-TEN TEAKWOOD COVERS

Assorted sizes.

1102-FOUR TEAKWOOD STANDS

Oblong.

1103-TWO TEAKWOOD STANDS

1104-THREE TEAKWOOD STANDS

Oblong.

1105-SIXTEEN TEAKWOOD STANDS

Odd shapes.

1106-TWELVE TEAKWOOD STANDS

Odd shapes.

110\%-ELEVEN TEAKWOOD STANDS

Odd shapes.

1108-THREE TEAKWOOD STANDS

Oblong.

1109-SIX TEAKWOOD STANDS

Odd shapes.

1110—THREE TEAKWOOD STANDS

Oblong.

1111-SIX TEAKWOOD STANDS

Assorted sizes. 


\title{
FIFTH AFTERNOON'S SALE \\ MONDAY, JANUARY 22D, 1906
}

\section{AT THE AMERICAN ART GALLERIES}

\author{
BEGINNING AT 2.30 O'CLOCK
}

\section{JAPANESE INROS (MEDICINE CASES)}

1112-INRO

One section. Polished black lacquer. Decoration of crayfish and seaweeds in various lacquers and incrustations. Carved ivory netsuke, openwork design and gold dragon inlay, by Sō. Cloisonné ojime.

1113-INRO

Four sections. Powdered gold lacquer. Decoration of rain dragon amid cloud forms in gold, silver and black lacquers. Interior of nashiji. Carved wood netsuke: a coiled serpent; metal o.jime.

$1114-I N R O$

Three sections. Tsuikoku lacquer; carved scrolls patterns. . Seventeenth century. Netsuke: carved wood nut; agate ojime.

\section{5-INRO}

Four sections. Outer surface of tree bark and lacquered. Ornamentation modelled in relief in ivory and stone: chicken-cock, hen and bamboo tree. Signed by Soseki. Netsuke: natural foot of a crane; metal ojime. 
Four sections. Mirror-black lacquer. Decoration of various implements used in spinning, in gold and silver. Carved wood netsuke: man with grotesque mask. By Kogioku. Metal-work ojime.

$111 \%-I N R O$

Five sections. Gold lacquer of high grade. Decoration of a basket of fruit and cluster of grapes in various layers of lacquers. Interior of Giobu nashiji lacquer. Signed by Jitokusai. Fine gold netsuke of peony design. Silver bronze ojime.

1118-INRO

Four sections. Carved ivory. Cloud forms and scrolls in deep carving, and storks in high relief in panels. Signed Kagatoshi. Ivory netsuke: a pine cone with miniature figures of the long-lived couple within. Carved ivory ojime.

1119-INRO

Four sections. Black and powdered gold lacquer. Decoration of kiri leaves and well curb in gold lacquer applied in several layers. Interior of nashiji. Carved ivory netsuke: bat; shibuichi ojime.

1120-INRO

Four sections. Fine gold lacquer. Finely pencilled decoration of pine grove and wild geese in flight, in different tones of gold. Nashiji interior. Gold lacquer netsuke: mask box; metal-work ojime.

1121-INRO

Four sections. Gold lacquer. Artistic decoration in various tones of gold and metal-work. Figure of genii resting in the mountains beneath a pine tree. Interior of nashiji. Signed by Kakosai. Gold work by Akimori. Carved ivory netsuke: a sleepy Chinaman; stone ojime.

1122-INRO

Four sections. Gold lacquer of high grade. Decoration of pine tree, cloud forms, water and storm dragon executed in high relief in various layers of gold; incrusted with two finely wrought metal-work figures, the subject illustrating a Chinese legend. Interior of Giobu nashiji lacquer. Signed by Kajikawa. Carved ivory netsuke: group of horses, by Tomo-chika; gold stone ojime. 
Four sections. Decoration of brocade patterns, screen and hibachi in gold lacquer, mother-of-pearl and lead incrustation. Metalwork netsuke and ojime.

\section{4-INRO}

One section. Polished black lacquer. Decoration of bird on persimmon branch in mother-of-pearl incrustation and lacquers; etched bamboo branches on reverse. Signed: Masatoshi, 1750. Carved ivory netsuke: Tengu with large gourd; metal-work ojime.

\section{5-INRO}

Four sections. Fine gold lacquer. Finely executed decoration of shrubs in applied gold, and clusters of berries incrusted in coral and malachite; interior of nashiji. Signed by Shokasai. Carved ivory elephant, incrusted with mother-of-pearl, coral and turquoise, for netsuke, by Masaharu. Agate ojime.

\section{$1126-I N R O$}

Four sections. Lacquered in imitation of iron, and ornamented with numerous medallions in imitation of "zogan," or gold damascene. Signed by Kajikawa. Netsuke and ojime to conform.

\section{$112 \%-I N R O$}

Four sections. Polished black lacquer. Decoration of pine tree, torii and Japanese temple guardian carrying a lantern in motherof-pearl incrustation and red, gold and brown lacquers applied in relief. Carved wood netsuke: woman carrying child on her back; metal-work ojime.

1128-INRO

Three sections. Ivory; carved basket pattern. Ornamented w:th medallions and verse of poetry in various lacquers. Finely carved ivory netsuke; metal ojime.

1129-INRO

Two sections. Iron; gourd design. Cloisonné ornamentation. Netsuke and ojime of iron and other metals.

1130-INRO

Three sections. Red lacquer, decorated in relief with mountaineer and goat, in green and white lacquer. School of Ritsuwo. Lacquered netsuke and ivory ojime. 
Three sections. Gold lacquer. Decoration of Japanese landscape and river view finely painted in low tones of lacquers. An exceedingly fine example of seventeenth-century workmanship. Walnutshell netsuke carved in openwork.

\section{2-INRO}

Three sections. Lacquered to imitate wood grains. Persimmon and lobster in gold and red lacquer. Carved wood netsuke: string of old coins; wood ojime.

\section{$1133-I N R O$}

One section. Silver, with outer case of shibuichi. Decoration of cherry tree in blossom and flying sparrow, wrought in relief in gold, silver and copper. Ivory netsuke, with metal-work panel; shibuichi ojime.

\section{4-INRO}

Four sections. Covered with minute mother-of-pearl incrustation, over which is an ornamentation of waving millet in gold lacquer, and sparrows battling with the wind, wrought in red bronze and applied in relief. Carved wood and tinted netsuke: a crying child; large green glass ojime.

\section{5-INRO}

One section. Polished brown lacquer. Relief ornamentation of frog, grasses and a closed umbrella in mother-of-pearl and lead. Carved wood netsuke: frog on an old pail; ivory ojime.

\section{$1136-I N R O$}

Four sections. Covered with tortoise-shell, which is ornamented with carved Dog Foo disporting among rock and peonies. Carved wood and tinted netsuke: figure of a priest, by Shuzan; metal-work ojime.

\section{$1187-I N R O$}

Four sections. Black and powdered gold lacquer of high grade. Finely pencilled decoration of floral basket, writing table, utensils and vase containing peacock feathers executed in various lacquers and mother-of-pearl inlay. Interior of fine nashiji. Signed by Jiosen, 1750. Miniature lacquered cabinet for netsuke. Metal ojime. 
One section. Plain wood. Ornamentation, finely carved in relief, the Gods of Wind and Thunder. Carved wood netsuke: demon trying to open temple drum, by Riōchō; carved ojime.

From the Brayton Ives Collection, Catalogue No. 244.

1139-INRO

One section. Brass. Inscription and scrolls in repoussé and incised. Netsuke and ojime to conform.

1140-INRO

Three sections. Vermilion lacquer. Decoration of peony in bloom in lacquers and mother-of-pearl. Carved ivory netsuke: boy playing flute; coral ojime.

\section{$1141-I N R O$}

'Three sections. Carved wood: Dogs Foo, flowers and drapery carved in bold relief. Carved wood netsuke: a worm-eaten bean; ojime of openwork carving.

\section{$1142-I N R O$}

Four sections. Gold lacquer. Decoration of bunches of grapes in relief lacquer and mother-of-pearl inlays. Netsuke: a carved walnut shell, by Sentō; gold stone ojime.

\section{$1143-I N R O$}

'Two sections. Polished black lacquer. Artistically executed ornamentation of dragon-flies in various lacquers and mother-of-pearl. Black and gold lacquer netsuke; ivory ojime.

\section{$1144-I N R O$}

Five sections. Black lacquer. Artistic decoration of numerous rabbits among dew-laden grass, executed in various tones of gold, and silver pin-head inserts. Carved ivory netsuke: a rabbit, by Ranichi. Metal rabbit ojime.

\section{5-INRO}

Five sections. Polished black lacquer. Richly embellished with warriors' helmets, masks, weapons and trophies in gold and red lacquers executed in relief. Miniature helmet for netsuke; shibuichi ojime. 
Four sections. Decorated in low relief, with tree peonies in bloom in gold lacquers and disporting Dogs Foo in carved tortoise-shell. Carved wood netsuke: Dog Foo and peony, by Jame-Taka. Agate ojime.

$114 \%-I N R O$

Four sections. Black lacquer. Decoration: storks in flight and among bamboo, in fine gold lacquer and inlaid with mother-ofpearl. Interior of nashiji lacquer. Carved ivory netsuke, with metal panel in designs of storks; metal-work ojime.

From the Brayton Ives Collection, Calalogue No. 262.

\section{8-TWO INROS}

(a) Giobu lacquer, with relief ornamentation in mother-of-pearl, ivory and gold lacquer. Carved ivory netsuke: Dog Foo on cinnabar mat; bronze ojime.

(b) Carved wood, with inscriptions in mother-of-pearl. Netsuke and ojime to conform. (Both imperfect.)

$1149-I N R O$

Four sections. Repoussé brass, gourd-shaped. Ornamented with symbolical inscriptions. Netsuke to conform; red bronze ojime.

$1150-I N R O$

Three sections. Black lacquer, of ribbed surface. Decoration of various bands in gold lacquer and mother-of-pearl inlay. Carved ivory netsuke; metal-work ojime. Early eighteenth century.

1151-INRO

Five sections. Gold lacquer; decoration, in various tones, of cascade and mountain scenery. Figure of woodman carrying pail wrought in various metals and inserted. Interior of nashiji. Signed Giokuriuken Komei. Eighteenth century. Gold lacquer netsuke and ojime.

$1152-I N R O$

Three sections. Polished black lacquer. Decoration of seaweeds and shells in various lacquers and mother-of-pearl, coral and malachite incrustation. Eighteenth century. Carved wood shell-shaped netsuke; metal-work ojime by Tenmin. 
Four sections. Outer surface covered with tortoise-shell and incrusted with mother-of-pearl; river view and mountain scenery. Edge and borders of powdered gold lacquer. Eighteenth century. Carved ivory netsuke: pleasure boat, by Anrakusai. Metal-work ojime.

\section{$1154-I N R O$}

Four sections. Metallic lacquer. Decoration of Nō dancer's robe and hat, in several layers of gold. Interior of nashiji. Carved ivory netsuke: Japanese chessmen; enamelled ojime.

\section{5-INRO}

Four sections. Polished black lacquer. Decoration of storks in gold lacquer and mother-of-pearl inlay. Eightecnth century. Metal-work and mother-of-pearl netsuke; drum-shaped; cloisonné ojime.

1156-INRO

Three sections. Fine nashiji lacquer. Decoration of a loom, in gold and silver lacquer, applied in various layers. Interior of gold lacquer. Signed by Koma Kiūhaku. Nashiji and gold lacquer netsuke; agate ojime.

\section{$115 \%-I N R O$}

Four sections. Red lacquer; fluted surface. Decoration of bold dragon modelled in high relief in gold and other lacquers. Carved wood and lacquer netsuke: demon on temple drum; stone ojime.

\section{$1158-I N R O$}

Four sections. Polished black lacquer, clouded with gold. Artistic decoration of pine grove in numerous layers of gold. Signed by Shiomi, at age of 81 . A very rare specimen. Carved wood netsuke: demon trapped by a clam; agate ojime.

1159-INRO

Four sections. Dull gold lacquer. Decoration of warrior and Japanese woman painted in red, black, brown and silver lacquers. Signed by Toshihide. Netsuke: carved ivory mask, by Shungioku; gold stone ojime. 
Four sections. Polished black lacquer powdered with gold. Decoration of peonies in bloom in gold lacquer, and butterflies in motherof-pearl incrustation. Interior of nashiji. Early eighteenth century. Ivory netsuke, with metal-work panel and bronze ojime.

\section{$1161-I N R O$}

Four sections. Black and powdered gold lacquer. Decoration of falcons on perch in gold and red lacquers and mother-of-pearl incrustation. Interior of nashiji. Signed by Kajikawa Riusho. Carved ivory netsuke: monkey and miniature screen. Metal-work ojime by Tenmin.

\section{2-INRO}

Five sections. Black lacquer, with gold mosaic surface. Decoration of weaving implements in low tones of gold. Interior of fine nashiji. Seal mark of Kajikawa. Carved wood netsuke: Tengu emerging from shell; iron ojime.

$1163-I N R O$

Four sections. Gold lacquer. Decoration: pine grove partially obscured by descending clouds. Interior of nashiji. Signed by Sōchōsai. Ivory netsuke: button design, with figure of God of Wisdom carved in low relief by Masayuki. Ivory ojime.

$1164-I N R O$

Three sections. Plain kiri-wood, decorated with figure of Shinto priest and his travelling outfit in gold lacquers. Carved ivory netsuke: "The Dutiful Son," one of a series of the twenty-four filial duties. By Masatsugu. Wood ojime.

\section{$1165-I N R O$}

One section with three small bottles inside. Brown lacquer sprinkled with gold. Delicately pencilled decoration of cascade, and bundle of faggots, gourd and maple leaves in raised gold. Signed by Tōyō. Carved wood netsuke: a farmer hiding under a sack from fox, by Giokuriū; iron ojime.

1166-INRO

Four sections. Giobu nashiji lacquer. Decoration of mask-box and masks in relief in various lacquers and metal inlay. Ivory netsuke and bronze ojime of mask design. 
Five sections. Gold lacquer. Finely executed decoration in numerous layers of gold lacquer and metal-work insertions, representing God of Longevity and his deer beneath a pine tree, landscape, river view and storks in flight. Interior of Giobu nashiji. Date, eighteenth century. Carved ivory netsuke of openwork design; metal ojime.

1168-INRO

Five sections. Powder gold lacquer of high grade. Finely executed decoration of mountain scenery, river view and rain storm in numerous layers of gold. Interior of nashiji. Carved ivory netsuke: fish and lizard, by Hōitsu. Openwork metal ojime.

1169-INRO

Four sections. Black and gold lacquer. Artistic decoration of cherry tree in blossom, executed in gold lacquer and metal inlays. Carved wood netsuke: boy acrobat; shibuichi ojime.

11\%0-INRO

Four sections. Dull gold lacquer. Artistic decoration of Daimio, cart and pine trees. Nashiji interior. Early eighteenth century. Carved ivory netsuke: Japanese with rice mortar; silver ojime.

$1171--I N R O$

Carved wood, masked design. Inlaid ornaments of tortoise-shell and ivory. Movable eyes and tongue. Signed by Seisai. Carved wood netsuke: boy wearing hideous mask, beating a drum, by Demeyuma. Coral ojime.

$11 \% \%-I N R O$

Three sections. Design of a bundle of faggots, decorated in gold and other lacquers. Netsuke to correspond; carved lacquer ojime.

$11 \% 3-I N R O$

Three sections. Carved wood; design of turtle, by Tadakazu. Carved wood netsuke: a seated figure and ojime openwork.

$11 \% 4-I N R O$

One section. Bell shape; vermilion lacquer decorated with gold.

Carved wood and lacquered netsuke: Daruma; agate ojime. 
Four sections. Fine gold lacquer. Decoration in various layers of gold and incrusted ivory: gardener and family watching a meteor. Interior of nashiji. Signed by Kajikawa. Carved ivory netsuke: Japanese boy with sack; metal-work ojime.

$1176-I N R O$

Four sections. Gold lacquer. Decoration of eagle on cherry branch, in moonlight, executed in high relief in various tones of gold; interior of nashiji. Signed by Kajikawa. Carved ivory button-shaped netsuke; metal-work ojime.

\section{$117 \%$-INRO}

Four sections. Gold lacquer. Decoration of court noble and shōjō in garden, executed in various lacquers, mother-of-pearl and ivory inlay. Interior of nashiji. Carved ivory netsuke: two miniature figures playing the game of Go inside an orange; mother-of-pearl ojime.

\section{$11^{17} 8-I N R O$}

Three sections. Gold lacquer. Decoration of warrior's helmet and war baton, in various layers of gold and silver. Interior of nashiji. Eighteenth century. Carved ivory netsuke: hand of Shōki and demon; ivory ojime.

1179-INRO

Five sections. Black lacquer. Decoration of mountain scenery and Japanese huts in gold lacquer and mother-of-pearl incrustation. Interior of nashiji. Early. eighteenth century. Carved ivory and wood netsuke: wood-cutter resting; metal-work ojime.

Four sections. Giobu nashiji lacquer decoration. Folded paper and cords to represent butterflies, executed in relief in gold lacquer, lead and mother-of-pearl incrustation. Interior of gold lacquer. Signed by Koma Kiūhaku. Early eighteenth century. Ivory netsuke carved in openwork; metal ojime. 
Five sections. Lacquered in imitation of wood grains. Artistic decoration of branches of cherry blossoms in gold lacquer, motherof-pearl and lead incrustation. Carved wood enamelled netsuke of grotesque figure; carved ivory ojime.

\section{2-GIANT INRO}

Four sections. Polished black lacquer. Decorated with the

"Seven Wise Men of the Bamboo Grove," in several layers of gold and silver lacquers and mother-of-pearl inlay. Interior of fine nashiji. Carved carnelian netsuke and ojime.

\section{3-INRO}

Four sections. Soochow lacquer; carved ornamentation. Figures of Japanese sages beneath pine and willow trees. Netsuke and ojime to correspond.

\section{$1184-I N R O$}

'Three sections. Dull black lacquer. Floral crest and brocade designs in gold and silver lacquer. Carved ivory netsuke: compass; metal-work ojime.

\section{$1185-I N R O$}

Four sections. Cinnabar lacquer. Finely carved ornamentation: D aimio seated on veranda, beneath willow tree, and playing koto; on reverse, garden and interior view and pine tree. Cinnabar lacquer netsuke carved in openwork, and ojime to correspond. Ch'ienlung period.

1186-INRO

Four sections. Black lacquer, with gold mosaics. Gold lacquer panels, with decoration of $\mathrm{No}$ dancer and mountain scenery finely executed in relief in numerous layers of gold and metal inlays. Interior of fine nashiji. Inro by Jokasai. Carved ivory netsuke: dancing girl with drum, by Minkoku; shibuichi ojime.

\section{$118 \%-I N R O$}

Four sections. Gold lacquer of high grade. Artistic embellishment in numerous layers of gold and metal inlays: Shōki and a demon beneath a pine tree; and cloud forms, cascade and rocks. Interior of nashiji. Signed by Kajikawa; gold work by Nobukatsu. Carved ivory netsuke: boy with basket; silver ojime. 
Four sections. Gold lacquer. Finely executed decoration in various layers of gold and incrusted ivory. Japanese dignitaries and attendants on the seashore watching flight of storks. Interior of fine nashiji. Signed by Kakosai. Carved ivory netsuke: street musicians, by Nagatsugu; metal ojime.

\section{9-INRO}

Five sections. Lacquered surface in imitation of a coarse fabric.

Relief ornamentation in gold lacquer, coral and mother-of-pearl of a falcon, coral diver, flowering plants and other designs. Carved Soochow-lacquered netsuke: gourd; and agate ojime.

\section{0-INRO}

Four sections. Clouded gold lacquer. Decoration of horse under willow tree near stream, painted in gold and other lacquers. Signed by Kwagetsu. Carved ivory netsuke: horse; metal-work ojime.

\section{1-INRO}

Three sections. Design of flower bucket lacquered in imitation of wood grain. Decoration of flowering plants in gold lacquer, mother-of-pearl and metal incrustation. By Kajikawa. Carved wood and metal netsuke: mask with movable jaws and ears; metalwork ojime.

1192-INRO

Five sections. Gold lacquer of 'high grade. Finely executed relief ornamentation of mountain scenery, cascades and river views. Interior of fine nashiji. Signed by Kajikawa. Carved ivory netsuke: boy and reclining cow, by Tomotada; bronze and gold ojime.

$1193-I N R O$

Four sections. Gold lacquer of high grade. Artistically decorated with the famous subject known as "A Thousand Storks." Interior of nashiji. Signed by Kajikawa. Carved ivory netsuke: boy feeding pet stork; metal-work ojime.

1194-INRO

One section. Brown lacquer. Decoration of beehive, bee and bamboo branches in gold lacquer and mother-of-pearl inlay. Netsuke of carved wood, in design of tiger; metal-work ojime. 
Four sections. Dull gold lacquer. Artistic decoration of "Nō dancer" and performing monkey executed in raised gold and ivory incrustation. Interior of nashiji. Signed by Shōkwasai. Mother-of-pearl work by Shibayama. Carved ivory netsuke: monkey eating a peach, by Ransui; metal-work ojime.

1196-INRO

Four sections. Fine old nashiji lacquer, with ornamentation of sword ornaments in relief and in various tones of lacquer. Early seventeenth century. Netsuke of ivory, carved in design of frog on lotus leaf; silver ojime.

$119 \%-I N R O$

Four sections. Black lacquer. Decoration of drum, helmet and armor in relief, and lacquered in red and gold with mother-of-pearl inlay. Seventeenth century. Netsuke of ivory: Shōki and demon; ojime, carved ivory.

1198-INRO

Three sections. Black lacquer. Ornamentation of grotesque figure, birds in flight, and sea wall, in various lacquers and pottery incrustation. Signed by Hanzan. Netsuke of black lacquer, button-shaped; carved Chinese figure; shakudo ojime.

1199-INRO

Two sections. Round shape. Black lacquer, with decoration of tiger and bamboo on one side, and storm dragon on the other; all in fine gold lacquer heavily applied. Interior of nashiji lacquer. Seventeenth century. Carved wood netsuke of tiger and bead ojime.

1200-INRO

Two sections. Pouch shape. Band of diaper patterns in low-tone lacquer, with top border of gold nashiji and floral designs in black. Seventeenth century. Netsuke of carved wood: frog on sandal; lacquer bead ojime. 
Three sections. Lacquered in imitation of iron. Decoration of camelia japonica in gold lacquer and mother-of-pearl incrustation. Interior of gold lacquer, by Yōyusāi. Design by Hoitsu. Netsuke to correspond, by Yōyusāi, and designed by Hoitsu. Malachite ojime.

\section{SUPERB I.ACQUERS}

1202-TEA JAR

Design of an egg-plant. Carved and lacquered. Antique silk brocade bag.

1203-TEA CADDY

Brown lacquer. Made to imitate Japanese charcoal.

Height, 23/4 inches.

\section{4-SMALL NASHIJI LACQUER BOX}

Flat round shape. Gold lacquer painting of country house and cherry blossoms on nashiji ground. Rimmed with lead. Seventeenth century.

$$
\text { Diameter, 21/4 inches; height, 3/4 inch. }
$$

1205-SAKE CUP

Tall shape. Red nara lacquer.

Height, 2 inches.

1206-SEAL BOX

Chinese lacquer. Etched decoration of dragon on top of cover, and on the four sides panel designs of Hōwo bird, kirin, tiger and lion; the reserved spaces of conventional diaper patterns. Gold lacquer repairs.

Height, 2 inches.

120\%-PERFUME BOX

In design of a clam-shell. Gold lacquer decoration, with three small shells in black. Interior of aventurine lacquer. Eighteenth century. 
1208-SMALL PERFUME BOX

Fine black lacquer. Decorated on lid with bunches of folded papers and sacred balls of flames in gold lacquers of two shades. Interior is of aventurine lacquer. Eighteenth century.

Diameter, 23/4 inches; height, $1 / 2$ inch.

1209-TORTOISE-SHELL BOX

Round, flat shape. Gold lacquer paintings of peony flowers and leafy scrolls around the body and on top of the cover.

Diameter, 23/4 inches.

1210-PAIR SAKE BOTTLES WITH TRAY

Decorated with nashiji lacquer.

Height, 6 inches.

1211-THREE GOLD LACQUER TILES

Chrysanthemum flower and peonies pencilled in gold lacquer and inlaid with ivory and mother-of-pearl.

Diameter, 6 inches.

1212-SAKE CUP

Red lacquer. Gold lacquer painting of fan, stork, tortoise and pine tree.

Diameter, 6 inches.

1213-STAND FOR TEA CUP

Gold nashiji lacquer of fine quality. Decorated with water plants and stream in powdered and raised gold lacquer. Eighteenth century.

Diameter, 61/4 inches.

1214-SMALL TRAY

Oblong shape with low rim. Large leaf of lotus in black lacquer and small buds in gold lacquer. Signed by Taishiu, a pupil of Yeshiu.

Diameter, 61/4 inches.

1215-BLACK LACQUER TRAY

Flower-shaped. Decoration of five-clawed dragon in centre with border design of peony flowers and flowering vine in red, green and brown lacquers. Chinese specimen.

Diameter, 61\%4 inches. 
Gold and red lacquer. Decoration on the smaller one is a flowerpot and plants in raised yellow, green and blue lacquers. By Hakugioku. The larger is decorated with a pair of storks in the foreground, and sailing boats in the distance.

Diameters, $3 \frac{1}{2}$ and $3 \frac{1}{4}$ inches.

$121 \%-T R A Y$

Gold aventurine lacquer. Brocade patterns and kiri-leaf scrolls pencilled in gold. Seventeenth century.

Diameter, 7 inches.

\section{8-RED LACQUER BOWL WITH COVER}

Decoration of Hōwō bird and leafy scrolls in powdered gold lacquer of two shades upon a background of vermilion red. Exterior and base are lacquered in imitation of grains of wood. Interior is elaborately decorated with numerous flowers in gold lacquer, on vermilion red.

Diameter, 43\%1 inches; height, 3 inches.

1219-STAND FOR TEA CUP

Gold nashiji lacquer of reddish tone. Decoration of pine tree, bamboos and plum blossoms in gold lacquer. Eighteenth century. Diameter, 61/2 inches; height, 5 inches.

1220-TEA JAR

A natural gourd. Decorated with gold lacquer painting of string beans, flowers, leaves and vines; mother-nf-pearl and ivory incrustations.

Height, 4 inches.

1221-SAKE HOLDER

Brown lacquer in imitation of pottery. Decoration of fish and sea weeds in incrustation of mother-of-pearl and lacquer. Ritsu school.

Height, 51/4 inches.

\section{R2-THREE LACQUER TRAYS}

Two oblong and one round. The two oblong trays having a decoration of a bell on stand and basket with fish and shells incrusted in gold, silver and shakudo and painted gold lacquer; green lacquer border. Signed by Hōsen. The round tray has a decoration of a knife, branch of plum blossoms and a nightingale incrusted in mother-of-pearl and lacquered in relief upon a brown background. 
1223-SET OF THREE SAKE CUPS

Powdered gold and vermilion lacquers. The set is decorated with

a design of carps ascending waterfall (emblem of ambition) executed in powdered and raised gold lacquers of various shading and partly inlaid with squares of cut leaf-gold. Signed Ka-ki-kiu.

\section{4-PERFUME BOX WITH TRAY}

Trefoil-shaped. Decoration of storks and pine trees and cherry blossoms in gold lacquer painting. Eighteenth century.

$$
\text { Diameter, 53/4 by 31/4 inches; height, 21/4 inches. }
$$

\section{5-SET: OF THREE SAKE CUPS}

Vermilion red lacquer. The smaller of the three containing a design of the gate of the famous temple of Asa-ku-sa in Tokio, showing statuette of Niō; the medium size has design of gate-post, two figures and flocks of swallows; and the largest has a design of lamp, a man with spear, and pine trees.

Diameters, $4 \frac{1}{2}, 5$ and $5 \frac{1}{2}$ inches.

1226-TWO GOLD LACQUER HAIR-PINS

Decoration of carp and tortoise in gold lacquer.

122\%—TEA CADDY

Black lacquer ground upon which is a decoration of the imperial kiri and kiku in powdered and gold nashiji lacquer. Interior is lined with gold lacquer.

Diameter, 3 inches; height, 31프 inches.

\section{8-BRUSH HOLDER}

Bamboo design. Vermilion lacquer. Painting of peony flower and leaves in free-hand style. Chinese specimen. Gold lacquer interior.

1229- TOB ACCO $B O X$

A natural gourd. Decorated on the shoulder with a design of gourds and vines in gold lacquer painting. Cover incrusted with mother-of-pearl in design of sea-shells.

\section{Diameter, 31/4 inches; height, 2 inches.}

1230-GOLD LACQUER TEA CADDY

Cylindrical shape. Decoration of pine, bamboo and peony with three Toku-gawa crests painted in gold. Small tray inside. Interior of aventurine lacquer. Eighteenth century. 
Made of a natural gourd. Decorated inside with design of flowers and leaves and brocade patterns in gold lacquer upon a tortoiseshell background. The outer surface is ornamented with branches of plum blossoms in gold lacquer and inlays of mother-of-pearl and lead.

Diameter, 4 inches; height, $21 / 2$ inches.

\section{2-DESPATCH BOX}

Brown lacquer. Decorated on top with chrysanthemum flowers and butterflies, in fine wire inlay and in colored lacquer; the borders and sides are of lacquer, imitating wood grains.

Length, 12 inches; width, 41/2 inches; height, $31 / 2$ inches.

\section{3-ROUND TRAY}

Powdered gold lacquer of golden-bronze tone. In centre a pair of roosters produced in inlays of mother-of-pearl and painted in gold lacquer. Lead rim. Signed, Shōjo Korin tsukuru.

Diameter, $93 \%$ inches.

1234-ROUND TRAY

Decorated with lotus leaves and flowers and kingfisher in raised gold lacquer of green and brown tones; lotus flower incrusted with mother-of-pearl. Signed by Shōgiokusai.

Diameter, 9 inches.

1235-CINNABAR LACQUER PERFUME BOX

Plum blossom carved in high relief.

Diameter, 3 inches.

\section{6-GOLD LACQUER PERFUME BOX}

Design of a clam-shell. Decorated on top with small diaper patterns and scrolls with bands of mother-of-pearl inlay; on the sides are various sea-shells incrusted in mother-of-pearl. Inside is of aventurine lacquer.

$$
\text { Diameter, } 3 \text { inches; height, 11/2 inches. }
$$

\section{7-PERFUME BOX}

In four sections. Aventurine lacquer of clouded texture. Fine painting of chrysanthemum flowers floating on a stream, executed with much skill and kaste. Seventeenth century.

Diameter, 21/2 inches; height, 3 inches. 
Made of a Japanese sea-shell. Lotus flowers and a heron decorated on the top in gold lacquer. Mounted with carved wood.

Dianeter, 31/2 inches; height, 11/2 inches.

1239-SMALL GOLD LACQUER BOX

Chinese. Form in imitation of a grouping of gourd, shell and sceptre. Decorated in red, silver, green and yellow gold lacquers. Interior of aventurine.

Height, 11/2 inches; length, 31/2 inches.

1240-PERFUME BOX

In four sections. Chinese cinnabar lacquer. Carved decoration of

Chinese house and figures. Bands of flower designs.

Diameter, 21/2 inches; height, 3 inches.

1241-GOLD LACQUER BOX

Shape of a head-covering used in "No" dance. Gold lacquer tray inside. The cover decorated with a brocade pattern, dragon and medallion in variously shaded lacquers. Sides finished in mosaic gold lacquer. The tray is decorated with cherry blossoms and cloud forms. Back of the cover and inside of the box are of cloud form decoration.

Diameter, 51/4 inches; height, 11/2 inches.

1240-SMALL GOLD LACQUER BOX

Low circular-shaped. Crest of Toku-gawa family, pine, bamboo and camelias, painted in powdered gold on top and sides. Inside of aventurine lacquer. Eighteenth century.

Diameter, 31/4 inches; height, 2 inches.

1243-SMALL GOLD LACQUER BOX

Square, with overlapping cover. Decoration of crest of the Toku-gawa family, pine, bamboo and peonies in powdered gold lacquers. Interior of aventurine lacquer. Eighteenth century. Height, 21/2 inches; length, 23/4 inches.

1244-SMALL CABINET

Black lacquer, with fly-door and three small drawers inside. Decoration of various flowers and plants in gold and silver lacquers. Silver mounting. Interior of aventurine lacquer. Eighteenth century. 
In shape of a sparrow, called fuku-ra-suzume. Top of the cover in design of a sparrow with full expanded wings; the head and part of feathers are overlaid with leaf-gold.

Height, 13/4 inches.

1246-SMALL GOLD LACQUER BOX

Chinese. Representing a jar and bowl. Decoration of a covered jar and a bowl of peaches. The interior is of Chinese nashiji lacquer.

Height, 11/2 inches; diameter, 31/2 inches.

1247-PERFUME BOX

Hexagonal shape, in three sections. Black lacquer with filling of cut leaf-gold. Gold lacquer painting of maple and kiri-leaves. Early seventeenth century.

$$
\text { Height, 23/4 inches; diameter, 21/4 inches. }
$$

\section{8-SMALL BOX}

A natural egg. Gold lacquer decoration of Hōwō birds, flowers and other designs. Interior is covered with a dull powdered lacquer. Mounted on a lacquer stand.

Height, 23/4 inches; diameter, 2 inches.

\section{9-GOLD LACQUER BOX}

Square, with overlapping cover. Pine, bamboo, peonies and crests of family of Toku-gawa, decorated on top and sides in beautiful powdered gold lacquers of several shades. Interior of aventurine lacquer. Eighteenth century.

Diameter, 3 inches square; height, 3 inches.

1250-GOLD LACQUER BOX

In design of a group of boxes made in two sections. The decoration on the outer and inner surface is executed in gold lacquer of several shades and layers, and consists of a series of views of the famous Yoshi-no mountain, cherry tree in blossom and various streams. Signed by the artist, Okuda Shozu-Sai.

Diameter, 5 inches; height, 3 inches.

\section{1-SMALL LACQUER BOX}

With overlapping cover. Black lacquer, with gold lacquer painting of plum trees and blossoms, sprays of peonies, cherries and chrysanthemums. Interior of aventurine lacquer. With tray and stand to match. Eighteenth century.

Length, 43\% inches; height, 23/4 inches. 
Oval shape. Crest of Toku-gawa family, pine, bamboo and tree peonies painted in powdered gold and red lacquer. Interior of aventurine lacquer. Eighteenth century.

I.ength, 4 inches; height, $13 \frac{1}{4}$ inches.

1253-TWO SAKE CUPS

Powdered gold and red lacquer. The smaller contains view of

Sumi-da river with the famous Rio-go-ku bridge in foreground and banks of Mu-ko-jima and a view of Fujiyama in the distance, artistically painted in powdered gold lacquer by Kajikawa and signed. The larger has decoration of the Takasago couplc under an old pine tree, with a view of sunrise in the distance. By Chikuzan signed.

Diameters, 4 and $41 \frac{1}{2}$ inches.

1254-BOX WITH OVERLAPPING COVER

Aventurine lacquer. Hōwō birds, kiri flowers and leafy scrolls, decorated on the cover and on the four sides in powdered gold lacquer. Has metal cord-holders. Seventecnth century.

Length, 6 inches; width, 5 inches; height, 4 inches.

1255-LACQUER TRAY

Oblong shape with rounded corners. In centre is a design of a large flower vase, upon which is a statuette of Kwan-on executed in relief gold lacquer painting; the face of the figure inlaid ivory, and a spray of camelia flowers incrusted with mother-of-pearl and painted with gold lacquer upon a background in design of wickerwork.

Diameter, $73 / 4$ inches.

1256-PERFUME BOX

Old Chinese lacquer. Round, flat shape. Hōwō birds, peony flowers and floral vines painted in brown lacquer upon a yellow and etched background.

Diameter, 21/2 inches; height, 11/4 inches.

125\%-GOLD LACQUER PERFUME BOX

Flat, circular shape. Painting of minute figures of the seven household gods decorated on top of cover. Interior is of gold aventurine. Eighteenth century. 
Gourd-shaped. Black lacquer of beautiful quality. Design of ferns most delicately painted in gold lacquers of two shades, with slight ornamentation of very small silver pin-heads. Silver stopper in design of chrysanthemum flower.

Height, 81/2 inches; diameter, 5 inches.

\section{9-LACQUER PANEL}

A design of dragon holding a sacred ball, made of pottery and incrusted in high relief; border of scroll design in brown lacquer. Probably the work of Ritsuwo.

Height, 91/2 inches; width, 91/2 inches.

1260-SQUARE TRAY

Green and brown lacquer. Decoration of a god of thunder and storm-clouds in relief.

$71 / 4$ inches square.

1261-PAIR IMPERIAL BOWLS

Cinnabar lacquer. Flowers of paradise, leafy scrolls and inscriptions beautifully carved in high relief on an incised background. Lined with gilded metal. Carved and lacquered stands of lotus design.

Height, 51/2 inches; diameter, 6 inches.

\section{2-SMOKER'S PORTABLE CABINET}

In imitation of a trunk of pine tree. Three small drawers inside. Gold lacquer decoration of eagle and pine tree upon a beautiful black lacquer ground. Bronze charcoal-fire holder; ash receiver, and silver holder for tongs. Bronze mounting in design of pine cone and needles.

Height, 71/2 inches.

\section{3-LUNCH BOX}

In imitation of wicker basket-work, decorated with incrustations of mother-of-pearl and ivory in design of Chinese boys making a snow-ball, birds and flowers. Reverse of the cover is decorated with a design of reflecting moon, and grasses in polished gold and silver lacquer upon a black lacquer ground.

Diameter, 71/2 inches; height, $43 / 4$ inches.

1264-TWO CINNABAR LACQUER STANDS

Oblong. Carved leafy scrolls and flowers. Seventeenth century. Each, length, 81/2 inches; height, 31/2 inches. 
Brown lacquer. Lotus flowers and leafy scrolls carved in high relief and lacquered in yellow, red, green and gray. Bands of key patterns and diapers carved and lacquered.

Height, 9 inches.

\section{6-CABINET}

With stationary tray, and one drawer. Decorated with flowered vines, and fanciful crest design in powdered gold lacquer on a black lacquer ground. Interior of beautiful nashiji lacquer.

Length, 101/4 inches; width, 71/2 inches.

$1267-T R A Y$

Red and green lacquer. Shape of a war-fan. Decorated in imitation of leather in red and green lacquers.

Length, 14 inches.

\section{8-SCROLL BOX}

Gold nashiji lacquer. Painting of plum blossoms, pine needles and crests in powdered gold lacquer upon a nashiji lacquer ground. Interior of nashiji lacquer. Silver cord-holders. Eighteenth century.

$$
\text { Length, } 15 \text { inches; width, 31/2 inches. }
$$

\section{9-MANUSCRIPT BOX}

Nara red lacquer. The cover has a raised decoration of a horse and a monkey incrusted in carved ivory, teakwood and mother-ofpearl. Tray inside.

Length, 16 inches; width, 121/2 inches.

\section{2\%0-WRITING CASE}

Gold lacquer. Decoration of chrysanthemum and butterflies in polished and powdered gold lacquer; some of the butterflies are inlaid with mother-of-pearl, and overlaid with leaf gold. Reverse of the cover is decorated with butterflies in gold lacquer over a nashiji ground. Furnished with a silver water-holder and an inkstone.

$$
\text { Length, 91/4 inches; width, 71/2 inches; height, } 2 \text { inches. }
$$

12'1-WRITING CASE

Black lacquer. Decoration of old pine trees and storks executed in gold of many layers over a black lacquer ground. Reverse of cover is decorated with young pine trees on a nashiji ground. The interior is of gold nashiji finish. Has a silver water-holder with chased design and ink-stone.

Length, 91/2 inches; width, 83/4 inches; height, 17/8 inches. 
Kiri wood. Top of the cover has a carved decoration of bats and an ant. On the reverse is plum blossoms and river view painted on black lacquer ground. The surface is a faithful imitation of old worm-eaten wood. Furnished with ink-stone and a silver waterholder in design of crescent moon.

Length, 103/4 inches; width, 6 inches.

12\%3-WRITING CASE

Black lacquer of high polish. On top of the cover is a bunch of leaves, artist brush, and a small ornamental piece in design of a lion, faithfully executed in gold lacquers of pale gray, yellow and green tones; parts of the leaves are inlaid with very minute pieces of cut leaf-gold. On the reverse of cover is a decoration of temple bell, cherry blossoms and a travelling priest in gold lacquer. Eighteenth century. Has ink-stone and a silver water-holder in design of a crescent.

Length, 9 inches; width, 81/2 inches; height, 13/4 inches.

1274-SCROLL BOX

Red mitsuda lacquer. Large peony flowers boldly painted in red and two shades of white and green lacquers. Metal cord-holders at the sides. Green silk cords. Interior of brown lacquer.

Length, 151/2 inches; width, 4 inches; height, 23/4 inches.

\section{5-WRITING CASE}

Gold nashiji lacquer. Decorated on top with design of an inro, tobacco pouch, tea jar, incense burner, tea scoop and rouge box most faithfully reproduced. Reverse of the cover has a gold lacquer decoration of snow-clad bamboos, swallows, and peony flowers rendered in raised gold lacquer and inlaid with mother-of-pearl. Rimmed with lead. Early seventeenth century.

Length, 91/2 inches; width, 9 inches.

1276-WRITING CASE

Lacquered in imitation of bamboo, with borders in design of brocade neatly painted in gold over black lacquer. Interior of the box is covered with a mass of chrysanthemum flowers beautifully painted in gold lacquer on a black lacquer ground.

Length, 101/4 inches; width, 9 inches; height, 13/4 inches. 
Black lacquer. Gold lacquer painting of wave designs and flying geese, and moon in silver lacquer. Reverse of the cover has a view of a flower garden, rocks and two rabbits in powdered and raised gold lacquer. Has ink-stone and a shakudo water-holder in design of an egg-plant. Eighteenth century.

Length, 83/4 inches; width, 8 inches.

\section{8-WRITING CASE}

Chinese lacquer. Mother-of-pearl inlaid decoration of Chinese palace garden-scene with palace, pagoda, figures, mountain and pine trees, and borders of wistaria flowers.

Length, 10 inches; width, 8 inches.

\section{2\%9-WRITING CASE}

In form of a Japanese boat. Aventurine lacquer. The cover is decorated with a dragon, cloud forms and crests in gold lacquer painting. The reverse of cover is decorated with crests and bunch of chrysanthemum flowers in gold lacquer on a nashiji ground. Has a gilded bronze water-holder and an ink-stone. Seventeenth century.

Diameter, 9 inches by $43 / 4$ inches; height, 2 inches.

1280-WRITING CASE

Black lacquer, highly polished. The decoration on cover consists of pheasants in flight, a crescent, and autumn leaves floating on a stream pencilled in gold lacquer, and a partial incrustation in mother-of-pearl and Japanese verse overlaid with leaf-gold. On reverse of cover is a group of thread spools exquisitely pencilled in gold and silver lacquer and inlaid with mother-of-pearl. Furnished with ink-stone and water-holder of boat design wrought in gold and silver. Seventeenth century.

Length, 8 inches. .

12S1-WRITING CASE

Gold nashiji lacquer. The cover is decorated with a Chinese landscape and figures in gold lacquer painting. On the reverse a view of a Chinese mansion and garden-scene. Has bronze water-holder and ink-stone. Seventeenth century.

Length, 91/2 inches; width, 81/4 inches; height, 13/4 inches. 
Black and gold lacquer. The cover embellishment consists of a representation of a Japanese peace-drum, surmounted by a chicken-cock, artistically executed in various lacquers and cut leaf-gold inlays. On the reverse of cover is a landscape, river view, distant mountains and other designs beautifully pencilled in gold lacquer upon a fine nashiji ground. Gold lacquered inkstone and fine shakudo water-holder. Early seventeenth century.

Length, $91 / 4$ inches.

\section{3-WRITING CASE}

Gold nashiji lacquer. Gold lacquer painting of a cluster of chestnuts and leaves. On-reverse of cover is a decoration of a stag and maple tree. Furnished with ink-stone and bronze water-holder.

Length, 9 inches.

\section{4-WRITING CASE}

Aventurine lacquer. On the cover is a design of a slab imitating grains of wood in various shades of black, gold and silver lacquers. Upon this is a jardinière in which are trees and rocks representing a miniature garden; painted in raised gold lacquer of shaded tints; also two storks treated in raised gold lacquer. On the reverse of cover and on the interior surface is a decoration of landscapes, houses, a river scene with bridge and a group of three geese painted over an aventurine gold lacquer ground. Early seventeenth century.

Length, 85/8 inches; width, 8 inches; height, 17/8 inches.

\section{5-WRITING CASE}

Brown lacquer. On the cover are two horses at the foot of a tree, painted in powdered and raised gold lacquer of yellow and silvery gray tones. On reverse of the cover is a decoration of willow branches and flying swallows in delicately polished gold lacquer upon a beautiful ground of mirror black. Interior is of silver nashiji. Signed by Jōkasai, seal. Eighteenth century.

Length, 11 inches; width, 7 inches.

\section{6-WRITING CASE}

Black lacquer. Decorated with a scene of a Japanese bric-à-brac shop, showing visitors and shoppers going in and passing in front of the shop; most delicately and accurately painted in lacquer of various tints and highly polished. The reverse of cover and the interior are ornamented with birds and butterflies in colored lacquer on a silver-gray ground. Signed by Ogawa Shomin of Tokio. 
Of beautiful powdered gold lacquer of the highest quality with smooth surface. The cover is decorated with a rising sun, produced in exquisite "shu" red lacquer, and a descending crane painted in raised gold lacquer. The reverse of the cover is decorated with young pine trees, executed in raised gold and pencilled with lines of gold lacquer over each leaf; pine cones and stems are in mosaic gold filling. Interior is of gold nashiji lacquer of beautiful quality. Furnished with a bronze water-holder in design of a raft laden with cherry flowers in silver. Eighteenth century.

Length, 93/4 inches; width, $91 / 8$ inches.

\section{8-GOLD LACQUER BOX}

Decorated with branches of cherry flowers and scroll patterns in gold and silver lacquer upon a nashiji ground. Interior is of red lacquer. On the reverse of the cover is written in Japanese letters, Hitotsubashi, the name of one of the members of the Toku-gawa family.

$$
\text { Diameter, 121/2 by } 12 \text { inches. }
$$

1289-HANGING FLOWER VASE

Tall, square form. Kiri-wood, ornamented with figure of a sacred elephant made of pottery and inlaid with mother-of-pearl and decorated with gold lacquer. Chinese inscription on one side. Seal of Ritsuwo in green pottery.

Height, 9 inches.

1290-FLOWER PAIL

Makasa lacquer. Beautifully decorated with Hōwō birds and dragon in fine gold lacquer. Greek fret borders.

Height, 15 inches; diameter 11 inches.

1291-KIRI-WOOD HIBACHI

Decorated with Japanese house, maple tree and design of a stone lantern in mother-of-pearl and lead inlays, and painted with gold lacquer.

Diameter, 111/2 inches; height, 81/4 inches.

1292-LACQUER STAND

Oblong-shaped. Decorated with floral vines carved and lacquered in style called guribori, showing several layers of different lacquers.

Length, 12 inches; height, 8 inches. 
Black lacquer. Gold lacquer decoration of cherry blossoms. Two upper side panels are of openwork designs and covered with gold lacquer. Silver mountings.

Diameter, 12 inches square; height, 163/4 inches.

\section{4-BLACK LACQUER ROUND PANEL}

Painting of chestnut tree with chestnuts and leaves in relief workmanship. By Taishiu, a talented pupil of Zeshiu.

$$
\text { Diameter, 121/4 inches. }
$$

\section{5-CHINESE LACQUERED STAND}

Black and red lacquers. Has two shelves with panelled posts at the back and sides. Peony flowers, peaches, fungus and other ornamentation in gold lacquer, ivory incrustation and carved.

Length, 13 inches; width, 61/2 inches; height, 61/4 inches.

1296-JAPANESE SADDLE

Gold lacquer decoration of peony flowers on a black lacquer ground. Nashiji lacquer finish underneath.

129'-DAIMIO SADDLE AND STIRRUPS

Red lacquer, with decoration of Hōwo birds and crests painted in gold lacquer. Eighteenth century.

\section{8-DAIMIO TRAVELLING CHEST}

Gold lacquer decorations of crest of the Toku-gawa family. Black lacquer tray inside. Gilded bronze handles and mountings with chased design of leafy scrolls.

Length, 241/2 inches; width, 17 inches; height, 16 inches.

\section{9-BLACK LACQUER ROBE RACK}

Gold lacquer decoration of bamboos and plum blossoms. Chased brass mountings.

Height, 24 inches; length, 221/2 inches.

\section{0-DAIMIO TRAVELLING CHEST}

Brown lacquer. Decorated on top and sides with spots of gold and nashiji lacquer. Gilded bronze handles and mountings with chased design of leafy scrolls. Tray inside. 
1301-LADY'S MIRROR STAND

Gold nashiji lacquer. Two drawers, surmounted with an upright frame for holding a mirror. Decorated with floral designs in gold and silver lacquer. Chased brass mountings.

Height, 26 inches; length, 11 inches.

\section{SWORD RACKS}

1302-FOLDING SWORD RACK

Kiri-wood. For six swords.

Length, 18 inches; height, 111/4 inches.

1303-SWORD RACK

For four swords. Japanese keyaki-wood. Carved decoration of dragon.

Length, 151/2 inches; height, 111/4 inches.

1304-SWORD RACK

Kiri-wood. For five swords. Openwork decoration on the back panel.

Length, 123/4 inches; height, 101/2 inches.

1305-BLACK LACQUERED SWORD RACK

For three swords.

Length, 21 inches; height, 14 inches.

1306-CABINET SWORD RACK

For three swords. The cabinet contains three small drawers and one compartment with a shelf. A decoration of storks, tortoises, bamboo, pine trees and plum blossoms is painted in gold lacquer of various shades. Silver mountings and handles.

Length, 161/2 inches; width, 7 inches; height, 161/2 inches.

1307—SWORD RACK

For two swords. Black lacquer, decorated with mother-of-pearl inlay of dragon on one side and a tiger on the reverse. Ends and edges are also inlaid with mother-of-pearl.

Length, 141/2 inches; height, 103/4 inches.

1308-FOLDING SWORD RACK

For three swords. Lacquered in imitation of wood grain.

Length, 151/4 inches; height, $61 / 2$ inches.

1309-FOLDING SWORD RACK

For five swords. Kiri-wood. Openwork panels.

Length, 17 inches; height, 123/4 inches. 
1310-FOLDING SWORD RACK

Keyaki-wood. For six swords.

Length, 151/2 inches; width, 17 inches; height, 11 inches.

1311-FOLDING SWORD RACK

Black lacquer. For six swords. Decoration of flowers, dragon and butterflies.

Length, 163/4 inches; height, 121/2 inches.

1312-FOLDING SWORD RACK

Blacik lacquer. For three swords. Decoration of five-clawed dragons, cloud forms, waves, birds and various symbols in motherof-pearl inlays. Chinese specimens.

Length, 191/2 inches; height, 13 inches.

1313-FOLDING SWORD RACK

- For twelve swords. Kiri-wood. Stained and polished.

Length, 18 inches; width, 171/2 inches; height, 11 inches.

1314-FOLDING SWORD RACK

Keyaki-wood. Stained and polished. For five swords. Openwork panel.

Length, 19 inches; height, 81/2 inches.

1315-FOLDING SWORD RACK

Japanese hinoki-wood. For five swords. Openwork panels.

Length, 141/4 inches; height, 15 inches.

1316-FOLDING SWORD RACK

Japanese keyaki-wood. For six swords. Openwork panels.

Length, 161/4 inches; height, 121/2 inches.

131\%-FOLDING SWORD RACK

For six swords. Japanese kiri-wood, with panels of openwork decoration.

Length, 181/4 inches; height, 14 inches.

1318-FOLDING SWORD RACK

For five swords. Japanese keyaki-wood, with two panels of openwork floral design.

Length, 15 inches; height, 121/2 inches.

1319-FOLDING SWORD RACK

Keyaki-wood. For five swords.

Length, 17 inches; height, 151/2 inches. 
1320-BLACK LACQUER SWORD RACK

For three swords. Decorated with crest designs in gold lacquer.

Has one oblong drawer in base.

Length, 211/2 inches; height, 15 inches.

1321-BLACK LACQUER SWORD RACK

For three swords. Decoration of crests of the family of Tokugawa in gold lacquer.

Length, 223/4 inches; height, 121/2 inches.

1322-PAIR GREEN LACQUER PANELS

Painting of three birds and branches of tree in black, red and white lacquers.

Height, 15 inches; width, 111/4 inches.

1322a-SWORD RACK

Black lacquer with gold lacquer painting of wistaria flowers, grapes and birds.

Length, 223/1 inches; height, 141/2 inches.

\section{TEMPLE STANDS AND TABLES}

1323-SMALL CARVED TEAKWOOD STAND

Chinese. Square top. Openwork panels on four sides; carved ivory ornaments.

Length, 31/4. inches; width, 21/2 inches; height, 2 inches.

1324-CARVED STAND

Design of waves carved and gilded. The base has a decoration of sacred tortoises carved and gilded.

Height, 51/2 inches.

1325-CARVED STAND

Hexagonal shape. Gold lacquer on a brown ground. Carved and gilt ornamentations on base and inside of panels.

Diameter, 51/2 inches; height, 31/2 inches.

1326-LACQUER STAND

Hexagonal shape with six turned legs. Narrow panels decorated with cloud design in red lacquer on gray. 
Round top; supported by three legs in design of dragons' heads. Diameter, 6 inches; height, 5 inches.

1328-LACQUER STAND

Octagonal shape. Carved ornamentation, which is finished in gold lacquer to imitate metal-work.

Diameter, $8 \frac{1}{2}$ inches; height, 23/4 inches.

1329-SMALL TEMPLE STAND

Black lacquer top. Carved and gilded ornamentation of ducks and stream.

Length, 81/2 inches; width, 41/2 inches; height, $3 \frac{1}{2}$ inches.

1330-SMALL CARVED TEAKWOOD STAND

Chinese. Openwork panels and carved ivory ornaments.

Length, 51/4 inches; width, 3 inches; height, 53/4 inches.

1391-CHINESE TEAKWOOD STAND

Openwork carving of flower designs.

Diameter, 63/4 inches; height, 21/2 inches.

1332-CHINESE TEAKWOOD STAND

Square, with four low legs. The centre panel has medallion design, inside of which is a Chinese inscription or poem in mother-of-pearl inlay. Various symbols and flowers also in mother-of-pearl inlay. Diameter, 71/2 inches square; height, 31/2 inches.

1333-SMALL STAND

Japanese gold nashiji lacquer. Openwork decoration on six sides. Brass mountings.

Diameter, 7 inches; height, 4 inches.

1334-SQUARE TEAKWOOD TRAY

Openwork carving of leaves and vines in four panels, mounted with silver. Chinese specimen.

93/4 inches square; height, 3 inches.

1335-PAIR OF SMALL TEMPLE STANDS

Carved and gilded openwork panels.

Length, 91/2 inches; height, $4 \frac{3}{4}$ inches each. 
1336-TEAKWOOD STAND

Oblong. Carved ornamentation of peony flowers. Borders inlaid with silver wire in key-pattern.

Diameters, 9 by 6 inches; height, 23/4 inches.

1337-TEAKWOOD STAND

Round, flat top. Openwork carving of Greek fret.

Diameter, 101/2 inches; height, 33/4 inches.

1338-SMALL TEMPLE STAND

Openwork designs; gilded.

Length, 101/2 inches; height, 31/2 inches.

1339-TEAKWOOD STAND

Chinese. Openwork panels.

Diameter, 11 inches square; height 3 inches.

1340-SMALL TEMPLE STAND

Openwork and gilded decoration.

Length, 11 inches; height, 6 inches.

1341-SMALL TEMPLE STAND

Carved and gilded peony design on front panel.

Length, 111/4 inches; height, $51 / 2$ inches.

1342-CARVED TEAKWOOD STAND

Chinese. Oblong, with rounded corners. Carved jade rail around

the top. Carved ivory borders in centre.

Length, 11/1/2 inches; width, 61/2 inches; height, 51/2 inches.

1343-TEMPLE STAND

Gold nashiji top with gold lacquer ends. Carved and gilded panels of lotus flowers on four sides.

Length, 11 inches; width, 73/4 inches; height, 8 inches.

1344-SMALL TEMPLE STAND

Carved and gilded ornamentation of chrysanthemum flowers.

Length, 11/1/4 inches; height, $61 / 2$ inches.

1345-BLACK LACQUERED TEMPLE STAND

- Gold lacquer painting of kiri flowers and leafy scrolls; narrow panels below the top contain carved designs of mandarin ducks and pheasants.

Length, 111/2 inches; width, 81/4 inches; height, $71 / 2$ inches. 
1346-PAIR TEAKWOOD STANDS

Chinese. Carved decoration of leafy scrolls in openwork design.

Cloisonné enamel edges.

Diameter, 11 by $6 \frac{1}{2}$ inches; height, 3 inches each.

1347-TEAKWOOD STAND

Square-shaped. Carved decoration of peach trees and incrusted with floral designs in ivory and mother-of-pearl. Openwork ornaments.

Length, 111/2 inches; height, $63 / 4$ inches.

1348-CLOISONNÉ ENAMEL STAND

Square. Floral vines and key-patterns in various colored enamels;

edges at the top are ornamented with jewels in red, green and blue. Height, 103/4 inches.

1349-CARVED TEAKWOOD STAND

Chinese. Oblong, with rounded corners. Carved jade rail and carved ivory panels. Openwork teakwood base. Silk brocade cushion on the top.

Length, 111/2 inches; width, 61/2 inches; height, 51/2 inches.

1350-SMALL TEMPLE STAND

Carved and gilded peony ornamentation.

Length, 12 inches; height, 33/4 inches.

1351-CHINESE TEAKWOOD SQUARE STAND

Four panels contain openwork leafy scrolls.

Diameter, 12 inches square; height, $3 \frac{1}{2} 2$ inches.

1352-CHINESE TEAKWOOD STAND

Oblong. Four panels contain Chinese garden scenes, with numerous figures, houses and sacred animals in mother-of-pearl inlay. The lower panels are decorated with leafy scrolls and flowers. Corners are mounted with bronze.

Diameter, 12 by 71/2 inches; height, 4 inches.

1353-PAIR OF TEMPLE STANDS

Elaborately carved ornamentation of kiri, waves and lion heads around the base; centre panel contains a carved and gilt decoration of chrysanthemum flowers; and in the upper panels are carved Hōwō birds.

Length, 12 inches; height, 8 inches each.

1354-STAND

Round-shaped. ('arved decoration of butterflies and tassel design. Diameter, 12 inches; height, 8 inches. 
1355-CARVED TEAKWOOD OBLONG STAND

Chinese. Carved panels inlaid with mother-of-pearl. Silver mountings.

Length, 13 inches; width, 8 inches; height, 4 inches.

1356-CARVED TEAKWOOD STAND

Chinese. Openwork carvings of conventionalized key-patterns on the top rims and on the base.

Length, 13 inches; width, 81/2 inches; height, 31/2 inches.

135\%-FOLDING CABINET SWORD RACK

Japanese keyaki-wood. For four swords. Three drawers in base. Length, 13\%/4 inches; height, 93/4 inches.

1358-CARVED TEAKWOOD OBLONG STAND

Chinese. Openwork carving in four panels.

Length, 14 inches; width, 73/4 inches; height, 5 inches.

1359-OBLONG TEAKWOOD STAND

Supported by four turned legs. Openwork panels.

Length, 15 inches; height, 6 inches.

1360-TEMPLE STAND

Carved and gilded decoration of peony flowers.

Length, 211/4 inches; width, 6 inches; height, 5 inches.

1361-TEMPLE STAND

Low form. Black lacquer top with red lacquer front. Gilt decoration and brass mountings.

Length, 221/2 inches; width, 7 inches; height, 21/2 inches.

1362-TEAKWOOD STAND

Irregular shape. Supported by six turned legs mounted on a skeleton frame at the base. Carved ornamentation.

Length, 241/2 inches; height, 61/2 inches.

\section{STANDS FOR VASES AND ORNAMENTS}

1363-TWO TEAKWOOD STANDS

1364-THREE TEAKWOOD STANDS

1365-FIVE TEAKWOOD STANDS

Assorted sizes. 
1366-FOUR SQUARE TEAKWOOD STANDS

Assorted sizes.

1367-FIVE TEAKWOOD STANDS

Assorted sizes.

1368-FOUR TEAKWOOD STANDS

Oblong shape.

1369-TWO TEAKWOOD STANDS

Marble tops.

1370-FOUR TEAKWOOD STANDS

Assorted sizes.

1371-THREE TEAKWOOD STANDS

Table-shaped.

1372-THREE TEAKWOOD STANDS

1878-FOUR TEAKWOOD STANDS

Assorted sizes.

1974-FOUR TEAKWOOD STANDS

Assorted sizes.

1375-TWELVE TEAKWOOD STANDS

Assorted sizes.

1376-TWELVE TEAKWOOD STANDS

Assorted sizes.

1377-FOUR TEAKWOOD STANDS

Assorted sizes.

1378-FOUR TEAKWOOD STANDS

Assorted sizes.

1379-TWELVE SMALL TEAKWOOD STANDS

1880-TWO TEAKWOOD STANDS

Oblong shape. 
1381-FIVE TEAKWOOD STANDS

Assorted sizes.

1382-FIVE TEAKWOOD STANDS

Assorted sizes.

1383-TWO TEAKWOOD STANDS

Finely carved.

1384-FIVE TEAKWOOD STANDS

Assorted sizes.

1385-THREE TEAKWOOD STANDS

Square shape.

1386-FOUR TEAKWOOD STANDS

Assorted sizes.

1387-FIVE SQUARE TEAKWOOD STANDS

Assorted sizes.

1888-SIX TEAKWOOD STANDS

Assorted sizes.

1389-TWO FINELY CARVED TEAKWOOD STANDS

1390-PAIR TEAKWOOD STANDS

1391-FOUR TEAKWOOD STANDS

Assorted sizes.

1392-THREE TEAKWOOD STANDS

1393-FIVE TEAKWOOD STANDS

Assorted sizes.

1394-TWO TEAKWOOD STANDS

1395-THREE TEAKWOOD STANDS

Odd shapes.

1396-TWO TEAKWOOD STANDS

Finely carved. 
1397-FOUR TEAKWOOD STANDS

Assorted sizes.

1398-SIX TEAKWOOD STANDS

Assorted sizes.

1399-SIX TEAKWOOD STANDS

Assorted sizes.

1400-FIVE TEAKWOOD STANDS

Assorted sizes.

1401-THREE FINELY CARVED TEAKWOOD STANDS

1402-TWO TEAKWOOD STANDS

Oblong.

1403-THREE TEAKWOOD STANDS

Assorted sizes.

1404-FIVE TEAKWOOD STANDS

Assorted sizes.

1405-FOUR TEAKWOOD STANDS

Assorted sizes.

1406-FIVE FINELY CARVED TEAKWOOD STANDS

Assorted sizes.

140\%-PAIR OF TEAKWOOD STANDS

1408-FOUR TEAKWOOD STANDS 


\title{
SIX'TH AF'TERNOON'S SALE
}

\author{
TUESDAY, JANUARY 23D, 1906
}

\section{AT THE AMERICAN ART GALLERIES}

BEGINNING AT 2.30 o'CLOCK

\section{JAPANESE INROS (MEDICINE CASES) OF RARE AND FINE QUALITY}

1409-INRO

Five sections. Polished green lacquer. Decoration of serpent, frog, snail and bamboo grasses artistically executed in high relief in various lacquers. Signed, Koma Kansai. Carved wood netsuke: lotus leaf, by Bizan. Coral ojime.

1410-INRO

Four sections. Design of elephant, in gold and silver lacquer thickly applied on a fine powdered lacquer. Interior of gold nashiji. Seventeenth century. Carved wood netsuke: dog and peach fruit, signed by Masa-tomo. Ojime of carved ivory.

$1411-I N R O$

Four sections. Polished black lacquer. Outer case to conform, and ornamented in relief with a figure of priest and tiger in carved soapstone, and a writing-table and utensils, in vermilion and gold lacquers, artistically executed in relief. Carved cinnabar lacquer netsuke with shibuichi panel; agate ojime.

1412-INRO

Three sections. Polished brown lacquer. Beautifully decorated with far designs in various lacquers and mother-of-pearl inlays. Signed by Ota Masakata, 1730. Carved ivory netsuke: lotus leaf, with red bronze frog in relief; metal-work ojime. 
One section. Silver, with outer case lacquered in imitation of shibuichi. Decoration of numerous crests in gold, vermilion and other lacquers. Signed Bunsei, Monkey year, June 15th. KanSai. Carved wood and lacquered netsuke: snail on lotus leaf; shibuichi ojime.

1414-INRO

Five sections. Black lacquer, highly polished. Artistic ornamentation of two horses in powdered gold and silver-gray lacquer thickly applied. Interior of fine nashiji; signed by Kajikawa. Netsuke of stone: horse, and porcelain ojime.

\section{$1415-I N R O$}

Five sections. Of fine polished black lacquer. Designs of various screens, depicting bamboo grove and flower garden minutely and delicately painted in various lacquers of fine quality. Interior of fine nashiji. Signed by Kajikawa. Button-shape netsuke, with metal panel and ivory ojime.

\section{6-MINIATURE INRO}

Three sections. Nashiji lacquer, with ornamentation of peonies and rocks in gold leaf overlay and red lacquer. Seventeenth century. Netsuke and ojime of lacquer in conformity. Signed by Kosai.

$1417-I N R O$

Two sections. Carved wood; design of a locust. Netsuke and ojime to conform.

\section{8-INRO}

Two sections. Covered with a fine brown lacquer and decorated with two horses; one in black lacquer, the other mother-of-pearl inlay. Signed by Sōhei. Ivory netsuke, button design; gold stone ojime.

From the Brayton Ives Collection, Catalogue No. 256.

\section{9-INRO}

Four sections. Polished black lacquer. War-fan and baton, and various borders inlaid in mother-of-pearl and gold and silver leaf. Box-shape netsuke of similar workmanship; ivory ojime. 
Five sections. Gold lacquer. Decoration of peacock and peahen, pine tree and flowering peonies finely painted in lacquers of various tints in low relief. Interior of fine nashiji, signed Kajikawa. Ivory netsuke: Tengu and young; lacquered ojime.

1421-INRO

Three sections. Aventurine lacquer. Decoration, a view of Yedo, in various gold and other lacquers. Interior of nashiji. Carved wood netsuke: Pilgrim resting at roadside, by Morimitsu; motherof-pearl ojime.

1422-IN,RO

One section. Made of natural tree bark. Decorated with crests and symbols in gold lacquer. Carved ivory netsuke: a skeleton with scroll; openwork ojime.

1423-INRO

Four sections. Powdered gold lacquer. Decoration of chrysanthemum in bloom, in various layers of gold and mother-of-pearl incrustation. Interior of nashiji. Ivory netsuke: carved in openwork; mother-of-pearl ojime. Early eighteenth century.

1424-INRO

Four sections. Gold lacquer of high grade. Finely executed decoration of mandarin hawking party, pine grove and imperial carriage in various layers of gold and ivory incrustation. Interior of nashiji, signed by Kakosai. Carved wood netsuke and metalwork ojime.

1425-INRO

Two compartments. Tsuikoku lacquer. Carved peonies in black upon a red lacquer of wave pattern. Signed by Zōkoku. Netsuke of button design, with carved figure of old man; on reverse, three masks. Ojime of metal-work.

1426-INRO

Four sections. Decoration of deer in lacquer of shibuichi tone, and grasses in gold lacquer on a fine Hirame lacquer ground, interior of polished powder gold. Signed by Hogan Toshun. Netsuke of ivory : deer on mat; shakudo ojime.

From the Brayton Ives Collection, Catalogue No. 276. 
Five sections. Gold lacquer. Finely executed decoration: Dog Foo playing with a brocade ball with ribbon filets, in high relief and various layers of gold. Interior of Giobu nashiji. Carved ivory netsuke: Dog Foo on seal; silver ojime.

1428-INRO

Five sections. Gold lacquer of high grade. Finely pencilled decoration of landscape, pine and bamboo, birds in flight and other designs in numerous layers of gold. Interior of nashiji; signed by Kajikawa. Carved ivory netsuke of openwork design, by Todo. Fine metal-work ojime, by Shogiokusai.

1429-INRO

Two sections. Brown lacquer; ornamented in relief with fish and flowering plants with mother-of-pearl and gold lacquer. Carved ivory netsuke of dried fish and shakudō ojime.

1430-INRO

Four sections. Decoration of numerous horses in different attitudes, in gold, red and silver-gray, with mother-of-pearl inlay on a fine black lacquer ground. Interior, nashiji lacquer. Seventeenth century. Netsuke of wood and ivory: design of horse and rat; ivory bead ojime.

1431-INRO

Five sections. Gold lacquer of high grade. Mountain scenery and river view, finely executed in numerous layers of gold. Interior of nashiji; signed by Asaka Kanko. Carved ivory netsuke: mouse on dried fish; shibuichi ojime.

$1432-I N R O$

One section. Polished brown lacquer. Relief decoration of fishes in lacquers and mother-of-pearl. Signed by Yosei. Carved wood and lacquer netsuke, with metal ornament and bronze ojime.

\section{3-LARGE INRO}

Four sections. Polished vermilion lacquer. Decoration of bear and cubs frightened at crawling crabs, rocks and bamboo finely executed in high relief in gold and other lacquers. Carved Soochow lacquer gourd; agate ojime. 
$1434-I N R O$

Three sections. On one side, tiger in bamboo grove, in various tones of lacquer on a wood grain finish. On the reverse, dragon and cloud form in black, gold and silver lacquer. Seventeenth century. Netsuke and ojime of carved ivory in conformity.

\section{5-INRO}

Four sections. Polished black lacquer. Ornamentation of the six Nikko monkeys. "See no evil; hear no evil, and speak no evil," in gold and red lacquers, with mother-of-pearl inlay. Early eighteenth century. Wood netsuke and metal ojime of monkey.

$1436-I N R O$

Two sections. Ornamentation of sea weed in lacquer thickly applied, and fish, beautifully carved in mother-of-pearl incrustation upon a fine powdered gold lacquer ground. Interior of nashiji. Netsuke of ivory design of carp and signed by Masanao; carnelian ojime.

From the Brayton Ives Coliection, Catalogue No. 272.

\section{$1437-I N R O$}

'Three sections. Made of natural tree bark; ornamented with symbolical inscriptions in gold, silver and bronze. Carved ivory netsuke: peach pit with incrusted ornaments in ivory and tortoiseshell. Signed, Shibayama. Carved openwork ojime.

1438-INRO

Five sections. Gold lacquer. Decoration of plum tree in blossom, rooster, bamboo, birds, flowering plants and rice sheaves in applied gold and mother-of-pearl and ivory incrustations. Lacquered and ivory netsuke and metal and inlaid ojime.

1439-INRO

Three sections. Gold lacquer. Ornamentation: bird on branch of magnolia tree, which is in bloom, finely executed in mother-of-pearl inlays and gold lacquer. Signed, Chohei.

$1440-I N R O$

Four sections. Gold lacquer. Finely executed decoration in various layers of lacquer: Daimio family in garden, beneath pine tree, watching flight of storks; the faces of figures of carved ivory. Interior of fine nashiji. Eighteenth century. Carved ivory netsukc: boy with crane; agate ojime. 
Three sections. Polished black lacquer. Decoration of threeclawed dragon clutching sacred pearl, in various layers of gold, silver and red lacquers. Interior of nashiji. Carved ivory netsuke: figure of priest and dragon; stone ojime.

1442-INRO

Two sections. Design of masks. Powdered gold lacquer and inlaid mother-of-pearl and ivory. Interior of gold nashiji. Wood netsuke: a mask; cloisonné ojime. Eighteenth century.

From the Brayton Ives Collection, Catalogue No. 258.

\section{$1443-I N R O$}

Five sections. Old gold lacquer. Decoration represents landscape with view of a famous temple at Kioto, in various gold lacquers of many layers. Interior of gold nashiji and decorated. Signed by Fujiwara Kunihiro. Netsuke of carred wood: genii; openwork metal ojime.

$1444-I N R O$

Three sections. Soft paste porcelain, profusely decorated with Japanese domestic and ceremonial scenes; painted in brilliant enamel colors, enhanced by gilding and lacquers. Sedji porcelain netsuke: monkey and peach fruit.

\section{5-INRO}

Three sections. Black lacquer. Ornamentation of pigeon and branches of pomegranate, in mother-of-pearl and gold and red lacquers thickly applied. Signed by Shūto Hogenwo, at age of 80. Lacquer netsuke: locust; metal ojime.

\section{6-INRO}

Four sections. Powdered gold lacquer. Decorated with alternate stripes of gold and mother-of-pearl inlay, and diamio boxes and utensils in various tones of gold. Interior of nashiji. Carved ivory netsuke and metal-work ojime.

\section{$1447-I N R O$}

Five sections. High grade of gold lacquer of kirikane inlay. Artistic decoration of panel designs with exquisitely pencilled embellishments in various tones of gold. Interior of nashiji. Signed, Kajikawa, with seal. Carved ivory netsuke: design of a group of utensils; lacquered ojime. 
Four sections. Decoration: the famous 1,000 monkeys, in various attitudes; finely lacquered in red, gold and silver-gray upon a powdered gold lacquer surface. Interior of powdered gold lacquer polished. Early seventeenth century. Netsuke: ivory monkey ; copper ojime.

\section{9-INRO}

Three sections. Fine powdered gold lacquer. Each section is ornamented with group of deer in various attitudes in mother-ofpearl in flat inlay. Eighteenth century. Netsuke, gold lacquer with pottery and mother-of-pearl inlay; ivory ojime.

\section{0-INRO}

Four sections. Gold lacquer applied over vermilion. Decoration of figures of "Nō dancers," in various lacquers and metals in high relief. Interior of Giobu nashiji lacquer. Eighteenth century. Carved ivory netsuke: fabulous animal; metal slide.

\section{1-INRO}

Four sections. Gold lacquer of high grade. Finely executed decoration of equestrian and other figures illustrating a Chinese legend, in various lacquers and ivory incrustations. Interior of nashiji. Signed by Shokwasai. Inlay work by Shibayama. Carved ivory netsuke: demon and mouse; shibuichi ojime.

\section{2-INRO}

Four sections. Gold lacquer of fine quality. Decoration of cascade, pine and bamboo, rocks and cloud forms in high relief in various layers of gold; Dog Foo incrusted in mother-of-pearl. Interior of nashiji. Lacquer work by Shokwasai. Pearl inlay by Shibayama, and signed. Carved ivory netsuke: Dog Foo and sacred ball, by Tomochika; mother-of-pearl ojime.

\section{3-INRO}

Five sections. Gold lacquer of high grade. Decoration of mountain scenery and river view artistically executed and in high relief. Interior of Giobu nashiji lacquer. Signed Kajikawa. Carved ivory netsuke: frog on old straw sandal, by Masatsugu; bronze openwork ojime. 
Four sections. Gold lacquer of high grade. Decorated in high relief, in metal-work figures and pencilled with mountain scenery and bridge in various lacquers; scene depicting famous combat between Yoshitsune and Benkei on the Gojō bridge in Kioto. Interior of fine nashiji. Ivory netsuke, with metal-work panel; bronze ojime.

\section{$1455-I N R O$}

Five sections. Gold lacquer of high grade. Decoration of Daimio and children, beneath pine tree, in various layers of gold and vermilion lacquer and incrusted ivory. Interior of Giobu nashiji. Signed by Kakosai. Ivory inlay, by Yekimasa. Carved ivory netsuke: boy with turtle, by Riomin; ivory ojime.

$1456-I N R O$

Four sections. Fine gold lacquer. Decoration of seated figures of the six famous poets, finely executed in gold and other lacquers and ivory incrustation. Interior of nashiji. Carved wood and ivory netsuke: mask-box and mask; shibuichi ojime.

$1457-1 N R O$

Four sections. Gold lacquer of high grade. Finely pencilled decoration of landscape and river views of eight landscape medallions. Interior of nashiji. Signed by Jitokusai. Carved wood and enamelled netsuke : figure of God of Longevity; silver and gold ojime.

1458-INRO

Three sections. Design of a tablet of India ink. Decoration of a temple drum, surmounted by a rooster, modelled in high relief in gold lacquer and faience and incrusted mother-of-pearl. School of Ritsuwo. Ivory and metal-work netsuke: design of drum; metal-work ojime, by Tenmin.

1459-INRO

Five sections. Gold lacquer of high grade. Mountain scenery and river view, finely executed in relief in various tones. Interior of nashiji. Netsuke: carved ivory skull; metal-work ojime: skull and snake. Eighteenth century. 
Five sections. Gold lacquer. Decoration of Daimio cart, entrance gate and pine tree, in numerous layers of gold and silver lacquer. Interior of nashiji. Carved ivory netsuke: kylin; agate ojime.

$1461-I N R O$

Round shape. Black lacquer, with incrustation of ivory, pottery, lead, mother-of-pearl and lacquers. Decoration of Chinese landscape with palace on the obverse. Rooster, drum and desk ornament on the reverse. Rain dragon amid waves round edge. By Ritsu. Horn netsuke and carved ivory ojime.

\section{$1462-I N R O$}

Four sections. Decoration of Chinese landscape, with pagoda in silver, and branches of camelia japonica in gold lacquer and red ivory inlay. On the reverse, pine and persimmon tree; the fruits are of ivory in red and green; the whole on Hirame gold lacquer of fine quality. Seventeenth century. Carved wood netsuke and metal slide.

$1463-I N R O$

Two sections. Round-shaped. Ornamentation of a dragon and Hōwō bird in black and gold lacquer on a bright vermilion lacquer. The edge finished with kiri flowers and foliage. Seventeenth century. Cinnabar lacquer netsuke: Chinese boy; carnelian ojime.

$1464-I N R O$

Three sections. Gold lacquer of high grade. Beautifully executed decoration of mountain scenery, river view, storks and symbols, in numerous layers of gold and mosaic inlay. Giobu nashiji interior. Signed by Kajikawa. Carved ivory netsuke: demon on lotus leaf, by Minzan. Carved ivory ojime.

1465-INRO

Four sections. Fine gold lacquer. Decoration, the Poet Narishina and his attendant passing Mount Fuji, executed in gold lacquer, metal and mother-of-pearl inlays. Interior of nashiji. Signed by Shokwasai; metal-work by Nobukatsu. Carved wood horse for netsuke; bronze and shibuichi ojime. 
Four sections. Gold lacquer of high grade. Richly embellished with jardinière of flowers, and boys at play, executed in raised gold and mother-of-pearl and ivory incrustation. Interior of fine nashiji. Signed by Shokwasai. Pearl inlay by Shibayama. Gold lacquer, box-shaped netsuke, incrusted with Dog Foo in gold, and flowering plants in mother-of-pearl and coral. Signed by Kakosai. Metal-work ojime.

\section{$1467-I N R O$}

Three sections. Polished black lacquer. Decorated in bold relief with two figures representing a tug-of-war between a temple guardian and a demon, executed in gold and other lacquers. Interior of nashiji. Signed by Kōho, with seal mark. Ivory netsuke, with metal-work medallion, a demon's mask on a dish; bronze ojime.

From the Brayton Ives Collection, Catalogue No. 250.

\section{8-INRO}

Six sections, with small box in each compartment. Fine nashiji lacquer. Decoration of plum tree in blossom, pine and river view finely executed in numerous layers of gold lacquer. Early eighteenth century. Ivory netsuke of button design. Carved by Korin. Silver inlaid iron ojime.

From the Brayton Ives Collection, Catalogue No. 263.

1469-INRO

Four sections. Brown lacquer with etched ornamentation, with an outer case of polished black lacquer, which is ornamented in high relief with a pigeon perched on a persimmon tree, executed in shibuichi, copper and red lacquer. Carved lacquer netsuke and cloisonné ojime.

From the Brayton Ives Collection, Catalogue No. 24.5.

1470-INRO

Four sections. Powdered gold lacquer. Finely painted decoration in gold lacquers of various tones, mountain scenery, pine, bamboo, kiri leaves and cabinet in several tones of gold. Interior of nashiji and decorated. Fine metal-work netsuke and ojime. Early eighteenth century. 
Four sections. Old gold lacquer. Decoration of water and rocks in various styles of lacquer thickly applied. Interior of Giobu nashiji. Signed by Kajikawa. Ivory netsuke: dried fish and puppy; gold openwork ojime.

From the Brayton Ives Collection, Catalogue No. 267.

$1472-I N R O$

Three sections. Polished black lacquer. Decoration of Japanese lock and keys in raised gold, mother-of-pearl and lead incrustation.

Interior of gold lacquer. Ivory netsuke with metal-work panel and bronze ojime.

From the Burty Collection, Paris, Catalogue No. 284.

$1473-I N R O$

Three sections. Plain kiri-wood. Artistic decoration of three storks in gold lacquer. Signed by Komin. Gourd netsuke and bronze oj̣̣me.

$1474-I N R O$

Four sections. Old gold lacquer. Decoration of Chinese legendary subjects, in low relief in lacquers and mother-of-pearl inlay. Lacquered netsuke with ivory ornament of Dog Foo and drumshaped ojime. Early eighteenth century.

From the Burty Collectiox, Paris, Catalogue No. 244.

$1475-I N R O$

Four sections. Polished black lacquer. Dragon arising from the sea, modelled in low relief. Interior of nashiji. Signed by Bunriūsaï, a court artist. Lacquered netsuke and metal ojimc.

From the Burty Collection, Paris, Catalogue No. 403.

$1476-I N R O$

One section. Polished black lacquer. Decoration, view of Biwa, executed in gold lacquer of numerous layers. Carved ivory netsuke: fish-basket with adhering shells; metal-work ojime by Tenmin.

From the Bur'ty Collection, Paris, Catalogue No. 388.

$14 \pi n-I N R O$

One section. Carved wood, to represent a frightened servant. Signed by Giosai. Carved wood netsuke: Tengu emerging from. a shell. By Jiobun. Ojime of openwork carving. 
Three sections. Gold lacquer of high grade. Beautiful relief ornamentation of various insects in mother-of-pearl and lacquers. Interior of nashiji. Signed by Zühei (Shunshuhan). Ivory netsuke and ojime ornamented in conformity with inro. Netsuke by Shibayama.

\section{$1479-I N R O$}

Three sections. Outer surface of tree bark. Decoration of crest and butterfly in gold, silver and low-tone lacquers. Carved wood mask for netsuke, signed Nagamitsu. Bronze ojime.

From the Bing Coluecrion, Paris.

$1480-I N R O$

Four sections. Gold lacquer of high grade. Artistically executed decoration, in various tones of gold, applied in high relief: wood-gatherer watching waterfall, mountain scenery and hut; face of wood-gatherer in mother-of-pearl. Interior of fine nashiji. Signed by Yōkei (Sanseisai). Carved ivory netsuke: tiger and cubs, by Ranitsu. Stone ojime.

1481-INRO

Five sections. Decoration of chrysanthemums and foliage in various lacquers thickly applied on a black and powder gold ground. Interior of Giobu nashiji. Amber netsuke; cloisonné ojime.

From the Brayton Ives Collecrion, Catalogue No. 266.

$1482-I N R O$

Four sections. Powdered gold lacquer. Decoration of numerous dragon crests in various tones of gold. Interior of nashiji lacquer. Signed by Jokasai. Ivory netsuke carved in openwork and incrusted with sịlver storks by Hō (seal style). Cloisonné ojime.

Five sections. Powdered gold. Cherry tree in blossom in fine gold and silver-leaf lacquers. Interior of nashiji. Early eighteenth century. Netsuke of carved ivory: girl and demon; ivory ojime.

From the Brayton Ives Collection, Catalogue No. 274. 
Four sections. Beautiful decoration of three-clawed dragons in gold-leaf lacquer and mother-of-pearl inlay. Interior of powder gold lacquer. Signed by Toyo. Netsuke of horn, with an ornamentation of a dragon in iron and gold; silver ojime.

From the Brayton Ives Collection, Catalogue No. 279.

1485-INRO

Four sections. Black lacquer. Decoration of Jurojin-God of Longevity-after Sesshu, in powdered gold lacquer thickly applied. On the obverse, seal mark of the great Sesshu. Interior of Giobu nashiji. Netsuke, carved tortoise-shell and lacquered; bronze ojime.

From the Brayton Ives Collection, Catalogue No. 278.

\section{$1487-I N R O$}

Four sections. Design of an ink block. Black lacquer, with decoration of one of the Rakans. The face and chest of ivory, and robe of fine red lacquer. On the reverse, a Chinese poem. Signed by Hanzan. Netsuke: lacquer with iron panel. Carnelian ojime.

From the Brayton Ives Collection, Catalogue No. 271.

\section{$1488-I N R O$}

Four sections. Gold lacquer of high grade. Finely executed decoration in relief gold, depicting a scene from Japanese mythology: the figure of a priest beneath a waterfall seeing the vision of Kwan-on and her attendant. Interior of fine nashiji; signed by Hida Kozan. Carved wood and enamelled netsuke, and metalwork ojime.

1489-INRO

Four sections. Fine gold lacquer. Artistic embellishment of figures and mountain scenery representing the three wise men of China, executed in relief in different layers of gold lacquer and incrusted ivory. Signed by Shokasai Takujiro, 1810. Carved ivory netsuke: demon on temple drum; shibuichi ojime.

1490-INRO

Four sections. Black and powdered gold lacquer. Decoration of landscape views and cascade, in five fan-shaped panels, in various layers of gold lacquer. Interior of nashiji. Seventeenth century. Carved ivory netsuke: figure of a jolly sage. Metal-work ojime. 
Four sections. Dragon in silver and cloud forms in gold and red lacquers thickly applied on a fine powdered gold lacquer ground. Silver seal mark of Tou. Netsuke of copper, and ojime of ivory in design of dragon.

$1492-I N R O$

Four sections. Old nashiji. Decoration: eagles standing upon a rock, in silver, mother-of-pearl inlay and lacquer thickly applied. Interior of gold nashiji. Seventeenth century. Carved ivory netsuke: monkeys, and cat's-eye ojime.

\section{3-LARGE INRO}

Three sections. Old gold lacquer. Completely covered with numerous chrysanthemums in bloom in many layers of gold lacquer and incrustation of mother-of-pearl. On each side a large butterfly in relief in various tones of engraved shibuichi, and an overlay of gold. Interior of gold nashiji. Signed by Shofusai Tosen. Eighteenth century. Netsuke and ojime of ivory in conformity with the inro.

From the Brayton Ives Collection, Catalogue No. 285.

\section{$1494-I N R O$}

Four sections. Design of an ink block. On the obverse a decoration of Chinese landscape after a painting by Sogioku, and on the reverse a Chinese poem in black lacquer on a brown ground. Signed by Ritsuo. Netsuke: carved wood snail and lotus; shibuichi ojime.

1495-INRO

Three sections. Gold lacquer. Decoration of children at play, pencilled in various lacquers. Outer case of gold lacquer of basket pattern. Without netsuke or ojime.

$1496-I N R O$

Four sections. Ground of intricate mother-of-pearl inlay. Decoration of kiri-leaves in gold lacquer. Carved wood netsuke: boy rescuing companion who has fallen in a filled water-jar. Metal and enamel ojime. 
Four sections. Polished black lacquer. Artistic decoration in gold and mother-of-pearl incrustation, representing a rice field scarecrow and hut. Signed by Shiomi Masazane. Carved ivory of openwork design, with metal figure inserted. Metal-work ojime.

1498-INRO

Three sections. Hirado porcelain of pure white hard paste. Decoration of lozenge-shape disks outlined in underglazed blue. Porcelain netsuke: Japanese boy with mask.

1499-MINIATURE INRO

Five sections. Gold lacquer. Decorated with views of 53 famous places on 'Tokaido, from Yedo to Kioto, in various layers of gold lacquer. Interior of nashiji, signed by Kōusai. Carved work netsuke: boy playing flute seated on cow, by Tomotada. Silver ojime.

\section{0-UNIQUE INRO}

Three sections. Quadrilateral shape, in design of a Chinese seal, finely decorated with birds of paradise and branches of kiri-leaves, in low tones of lacquers; metal and mother-of-pearl loops at side for cord. An extraordinary example of Ritsuo's fine work and signed with his seal, "Kwan." Netsuke and ojime of carved walnut shells.

\section{SUPERB LACQUERS}

1501-SMALL BLACK LACQUER BOX

Gold lacquer painting of butterflies and autumn grasses artistically and accurately executed. Interior of aventurine lacquer. Diameter, 23/4 inches; height, $1 / 2$ inch.

1502-SMALL GOLD LACQUER TEA CADDY

With small tray inside. Decoration of pine, bamboo and peony flowers on cover and sides in powdered gold lacquer of two shades. Interior of aventurine lacquer. Eighteenth century.

Height, 2 inches; diameter, 21/4 inches. 
Flat, round shape. Old Chinese lacquer. Landscape and figures on a background of conventional wave design, incrusted with finely cut pieces of mother-of-pearl. On the sides is a decoration of grasses in mother-of-pearl inlays. Seventeenth century.

Diameter, 23/4 inches.

\section{4-PERFUME BOX}

In two sections. Exquisite painting of plum-blossoms of different stages carefully drawn in gold lacquers of yellow, green and pink tints, petals of flowers are brought out in relief, showing many layers of gold lacquers. Interior covered with mura-nashiji. Eighteenth century.

$$
\text { Diameter, 21/4 inches; height, 11/4 inches. }
$$

\section{5-SMALL BLACK LACQUER BOX}

Double oblong-shaped, containing four smaller boxes within.

Decoration of various insects and ferns in gold lacquer painting over a black lacquer ground. Covers of the four inside boxes are decorated with landscape and figures.

Length, 3 inches; height, 1/2 inch.

1506-SCROLL BOX

Oblong-shape. Aventurine lacquer. Leafy scrolls and peony flowers boldly painted over an aventurine lacquer background. Ring-shaped cord-holder on the sides. Seventeenth century. Length, 151/2 inches; width, 33/4 inches; height, 31/4 inches.

150\%-GOLD LACQUER PERFUME BOX

In design of a folded letter. Decorated on top with inlaid ornamentations of flowers in gold, silver, mother-of-pearl and coral incrustations, upon a background of cut leaf-gold and silver lacquer. Interior of aventurine lacquer. Seventeenth century.

Diameter, 31/4 inches.

\section{8-SMALL SQUARE LACQUER BOX}

In three sections. Beautiful mirror-black lacquer covers the top and sides, upon which is painted in gold lacquer a writing-bris? floating leaves, fruit, and a moon with cloudy sky effect; the mom is in silver inlay and the fruit in mother-of-pearl incrustatio Interior finished in a style called ishi-me-nashiji of high grad. Latter part of seventeenth century. 
1509-GOLD LACQUER PERFUME BOX

Design representing a Japanese court lady reading book. Decoration of robes, sleeves, skirts and dressing of hair are minutely and carefully executed in gold lacquer and in mother-of-pearl inlay. Gold nashiji lacquer on interior. Seventeenth century.

Length, 41/2 inches; height, 1 inch.

1510-PERFUME BOX

In three sections. Aventurine lacquer of red tone. A beautiful design of various fans and leafy scrolls minutely painted with gold lacquers of two shades. Seventeenth century.

Height, 3 inches; length 23/4 inches.

1511-BLACK LACQUER BOX

With overlapping cover. Ferns, mountain and moon and Japanese verse pencilled in gold and inlaid with silver. Inner surface is covered with sprinkled gold lacquer. Silver cord-holders. Green silk cords.

Height, 21/2 inches; diameter, 31/2 inches.

1512-SMALL GOLD LACQUER BOX

Shape of a small checker-board. Back of the cover is decorated with a design of temple drum and temple tent beautifully pencilled in powdered gold lacquer, and on the two sides are cloud forms similarly treated. Seventeenth century.

Length, 3 inches.

1513-FIVE GOLD LACQUER SMALL PANELS

Finely executed diaper patterns in gold lacquer of three shades and overlaid with leaf-gold and silver inscriptions signifying "samples of gold and silver powdered lacquers." Backs of the panels are finished with black lacquer.

\section{4-PERFUME BOX}

In design of a helmet. Outside is of Giobu nashiji lacquer, decorated with an inlay of silver wires. Interior of aventurine lacquer. Seventeenth century.

Diameter, 21/2 inches; height, 11/2 inches.

1515-SMALL BOX

Black lacquer, in design of folded paper. In three sections. Decorated on cover and sides with a design of lightning-bugs and ferns in mother-of-pearl inlay and polished gold lacquers of two shades. Interior of aventurine lacquer. Seventeenth century.

Height, 11/2 inches; diameter, 3 inches. 
Four-sided, with overlapping cover. Decorated on the top and the sides of cover with a design of chrysanthemum flowers floating on stream, in powdered gold lacquer. Small tray inside has a design of flying geese, and reeds in gold lacquer and mosaics of cut leaf-gold. Interiors of aventurine lacquers. Eighteenth century.

Diameter, 2 inches; height 11/4.inches.

\section{7-GOLD LACQUER TEA CADDY}

Covered with powdered gold lacquer of excellent quality and low tone. Decoration of clusters of the sacred pearl amid fire emblems profusely painted in gold, silver and brown lacquers. On the interior is a decoration of wave designs in powdered gold lacquer. Eighteenth century.

Height, 3 inches; diameter, 23/4 inches.

1518-SMALL BOX

A goose egg. Decorated on the outside with a design of various insects in gold lacquer. Interior is richly painted with designs of chrysanthemum flowers in powdered gold lacquer of two shades upon a powdered gold background.

\section{9-SET OF THREE SAKE CUPS}

Of beautiful nashiji lacquer. Decoration of Toku-gawa crests, diaper and brocade patterns and bamboo leaves, painted with great accuracy, in powdered gold and silver lacquers. Eighteenth century.

Diameters, $3 \frac{1}{2}$, 4 and $4 \frac{1}{2}$ inches.

\section{0-BROWN LACQUER BOX}

Oblong-shaped. Decorated on the cover and sides with designs of peony flowers and butterflies in gold lacquer and mother-ofpearl inlay. The interior is decorated with peony flowers and leafy scrolls in gold lacquer. Has silk cords.

Length, 51/2 inches; width, $4 \frac{1}{2}$ inches; height, 33/4 inches.

\section{1-CHINESE WRITER'S BRUSH HOLDER}

Black lacquer, with carved decoration of Chinese landscape and figures, and a stork and a figure with rooster incrusted in gold and bronze. 
1522-GOLD AVENTURINE LACQUER BOWL

Decorated inside and outside with crests and bamboo leaves over

a background of floral leaf pattern. Early eighteenth century.

Diameter, $5 \frac{1}{2} 2$ inches.

1523-GOLD LACQUER TEA CADDY

Aventurine lacquer, decoration representing a group of boatmen

towing river craft loaded with fagots; painted in powdered gold lacquer and inlaid with mother-of-pearl. Early eighteenth century.

Height, 4 inches.

1524-SET OF TWO TOY DINNER TABLES

Aventurine lacquer. Chrysanthemum flowers in gold and silver overlay, with reserves of diaper pattern carefully painted in gold lacquer over a nashiji ground. Seventeenth century.

Diameter, 5 inches; height, 31/2 inches.

Diameter, 51/2 inches; height, 4 inches.

1525-SET OF TWO TOY DINNER TABLES

Aventurine lacquer. A mass of small chrysanthemum flowers, most carefully painted in lacquer, and overlaid with gold and silver leaf; the reserve decorated with very small leafy scrolls over a nashiji ground. Seventeenth century:

Diameter, 5 inches; height, 31/2 inches.

Diameter, 51/2 inches; height, 4 inches.

1526-SMALL GOLD LACQUER BOX

Shaped to represent a folded letter. Decoration on the lid, of a boy riding on a cow's back beneath a willow tree, painted in black and gold lacquer. On the sides are lotus flowers and leafy scrolls in green lacquer pencilled over a dull gold background. Interior is of aventurine.

Diameter, 5 inches; height, 11/4 inches.

152\%-TRIPOD STAND

Aventurine lacquer. Decorated with crest, pine, plum and bamboo in powdered gold lacquer on a nashiji ground. Seventeenth century.

Diameter, 6 inches; height, 21/2 inches.

1528-BLACK LACQUER BOX

Painting of maple and kiri-leaves in two shades of red and gold lacquers over a background of black lacquer of beautiful polish and speckled with fine gold dots. Interior is of fine gold aventurine lacquer. Eighteenth century.

Length, 61/2 inches; height, 11/2 inches. 
Supported by four carved legs. Chinese sage riding on cow's back, plum blossoms and other designs finely carved. Ch'ien-lung. 1736-1796.

Height, 63/4 inches.

\section{0-BLACK LACQUER BOX}

Design of a Japanese straw-thatched house. Inlaid and gold lacquer decoration.

$$
\text { Length, 61/4 inches; height, } 6 \text { inches. }
$$

1531-SAKE BOTTLE

Powder gold lacquer. Medallions of dragons painted in raised gold lacquer. Central band, with Hōwō birds and floral vines in gold lacquer line-drawing. Eighteenth century.

Height, 7 inches.

1532-SET JAPANESE ARROWS AND QUIVER

Panel decoration of Chinese landscape with figures and animals, and peony flowers and leafy scrolls beautifully carved. Brass handles on neck. Ch'ien-lung period. Carved teakwood stand.

Height, $7 \frac{1}{2}$ inches.

153.3-SET JAPANESE ARROWS AND QUIVER

The quiver made of leather and decorated with gold nashiji lacquer with design of a dragon. Sixteen arrows complete with heads. Eighteenth century.

1534-LOW TRAY

On four feet. Aventurine lacquer. Gold and silver lacquer painting of chrysanthemum flowers and streams. Reverse is covered with aventurine lacquer. Seventeenth century.

Length, 71/4 inches; width, $63 \frac{3}{4}$ inches; height, $3 / 4$ inch.

\section{5-JAPANESE PILLOW}

Made of rattan and lacquered in red. Ends are of black lacquer decorated in gold lacquer with design of kirin and shrub.

Length, 8 inches.

\section{6-CINNABAR LACQUER BOX WITH STAND}

Design representing Chinese books. Elaborate carved decoration of numerous medallions, peony, plum blossoms, lotus and other flowers. Stand of cinnabar lacquer, with leafy scrolls and key patterns elaborately carved. Ch'ien-lung period. 
Black lacquer. Spray of lily, artistically rendered in gold lacquer and in incrustation of lead and mother-of-pearl on a beautiful mirror-black lacquer ground. The Korin school.

Diameter, 10 inches square.

\section{8-PICNIC BOX}

Aventurine lacquer of fine quality. Consisting of a sweetmeat box in five sections, octagonal-shaped sake bottle, deep bowl, and a shallow tray with silver top handle. The decoration consists of grape-vines, squirrels, peaches, persimmons, chestnuts, vegetables, gourds and vines, and maple leaves floating on stream. Eighteenth century.

Height, 101/2 inches; length, 15 inches.

\section{9-TWO CINNABAR LACQUER BOWLS}

Chinese landscape and figures finely carved inside of oblong-shaped: panels. Reserve space in diaper pattern. Ch'ien-lung period. Diameters, 11 inches.

1540-GOLD LACQUER BOX

In design of a spool. Fern patterns most minutely executed in two shades of gold lacquer over a background of thread design. Interior is of aventurine. Early eighteenth century.

Diameter, 31/4 inches; height, 31/2 inches.

1541-PORTABLE JEWEL CABINET

With three small drawers. Vermilion-red lacquer. The outer surface covered with a mass of flying butterflies, most carefully painted in gold lacquer. Mountings, handles and locks of silver. Length, $4 \frac{3}{4}$ inches; width, 3 inches; height, 31/2 inches. .

\section{2-PERFUME BOX}

Gold lacquer. In two sections, with small tray inside and with an outer cover. The decoration on top of the cover outside of the inner boxes and on the tray consists of autumnal grasses and Japanese poems in gold lacquers of high quality over a ground of finely powdered gold lacquers. Interior of gold nashiji of high quality. Eighteenth century.

Length, 6 inches; width, 51/4 inches; height, 31/2 inches, 
With overlapping cover. Finely powdered gold lacquer, decorated with butterflies and brocade pattern pencilled in gold and silver lacquers. Interior is of fine aventurine lacquer. Seventeenth century.

1544-GOLD LACQUER PERFUME BOX

Diameter, 31/2 inches.

In three sections, with overlapping cover. Top and sides profusely decorated with various sea-shells and wave design in gold lacquer. Interior of aventurine lacquer. Early eighteenth century.

Length, 33/4 inches; width, 31/4 inches; height, 31/4 inches.

1545-SMALL GOLD LACQUER CABINET

With fly-door and three drawers. Decoration of iris-flower garden in gold. Front of drawers decorated with shell design. Has silver handle, lock and hinges. Seventeenth century.

Length, 4 inches; width, 21/2 inches; height, 3 inches.

1546-GOLD LACQUER BOX AND TRAY

Double fan-shaped. A view of Mount Fuji, and a pine grove richly painted on the cover. The sides are decorated with various sea-shells over a gold-speckled ground. Reverse of the cover and interior of box are elaborately decorated with the design of whirlpools. The tray is embellished with a dragon and cloud forms executed with skill and minuteness.

Diameter, 51/4 inches; height, 13/4 inches.

1547-CHINESE CINNABAR LALQUER BOWL

Carved decoration of procession of Chinese dignitaries and attendants passing in front of a temple; garden scene in foreground; all minutely executed. Ch'ien-lung period.

Diameter, $4 \frac{1}{2}$ inches.

1548-CHINESE CINNABAR LACQUER BOX

Shape of pomegranate. Carved decoration of diapers, and lacquered in yellow and red.

Diameter, $43 \frac{3}{4}$ inches.

1549-PERFUME BOX

Double heart-shaped, in two sections, and with a tray inside. The decoration throughout, which is minutely painted in gold lacquer of various shades and layers, consists of landscape scenery, stream, tortoise and autumnal grasses. Early eighteenth century. 


\section{0-CHINESE CINNABAR LACQUER BOX}

In shape of Buddha's hand. Carved decoration of bats and cherry branch; on a ground of diaper patterns in brown lacquer.

Diameter, 6 inches.

\section{1-SET OF BOXES}

In three triangular sections. Gold lacquer of powdered finish. Decoration on the top of the covers of persimmon fruits, grapes and wistaria branches in a delicate and artistic manner. Interior of aventurine.

Diameter, 61/2 inches; height, 11/2 inches.

\section{2-TEA BOX WITH TRAY}

Aventurine lacquer. Decorated with Japanese historical scenes from the "Genji-monogatari" (a famous novel), and various views, most faithfully depicted in gold lacquer of fine quality. The tray is decorated with landscape and houses over a nashiji ground. Seventeenth century.

Longth, 61/2 inches; width, $3 \frac{3}{4}$ inches; height, 41/4 inches.

\section{3-SMALL GOLD LACQUER BOX}

Containing four minute boxes, in design of Japanese books. The top of lid has a decoration of a falcon perched on a frame-shaped stand, executed in various layers of lacquers, and embellished with pencilled gold. The reserved space of lid and the four sides of the box are decorated in mosaic style with cut leaf-gold. Four boxes within are of gold lacquer and inlaid with mother-of-pearl. Seventeenth century.

Length, $4 \frac{1}{4}$ inches.

\section{4-WRITING BOX}

In two sections with tray inside. Exceedingly fine black lacquer covering its entire surface. Embellished with views of famous Japanese landscapes most accurately and artistically pencilled in gold lacquers of various shades. Interior covered with gold mosaic lacquers. Has a bronze water-holder and an ink-stone. Seventeenth century.

Length, 5 inches; width, 43/4 inches; height, 31/2 inches.

\section{5-GOLD LACQUER BOX}

In design of a pair of mandarin ducks, faithfully reproduced in gold and silver lacquers. Interior coated with a gold nashiji lacquer of high quality. Eighteenth century. 
1556-PERFUME BOX WITH TRAY

In shape of a kiri-flower. Gold nashiji lacquer. The cover is ornamented with kiri-leaves within diapers and key patterns accurately executed in gold lacquer. Interior has a decoration of kiri-flowers and vines on a nashiji ground. Seventeenth century. Diameter, 63/4 inches; height, $41 / 4$ inches.

1557-GOLD LACQUER BOX

A Japanese lady's hair-pin receptacle. Gold lacquer decoration of diamond-shaped panels, within which are various flowers, grasses and diapers. Interior of aventurine lacquer.

Length, 8 inches; height, 11/4 inches.

1558-TEA BOX

Double lozenge-shaped. Gold and black lacquer. The cover is decorated with a musical instrument " biwa" and a pair of dancing cranes; the sides with streams which are inlaid with mother-ofpearl and lead and ornamented with gold lacquer painting. Reverse of the cover is decorated with a portrait of one of the hundred famous poets and one of his poems, which is written in black lacquer. By Korin. Signed, Seisei Korin-tsukuru.

Height, 51/4 inches; diameters, $71 / 2$ and 7 inches.

1559-GOLD LACQUER TRAY

Supported by figures of two boys.. Ornamentation of pine trees and pine needles, and floral vine in gold lacquer. The two figures are skilfully carved and their costumes embellished with gold lacquer painting of brocade patterns. Eighteenth century.

Height, 5 inches; diameter, 9 inches.

\section{0-PERFUME CABINET}

Gold lacquer. Containing a jar and small perfume box with three sections. The cabinet has side drawer. The whole exterior of the cabinet and two smaller pieces have a decoration of conventional diamond patterns and flowers; the top and one side are ornamented with pierced designs of chrysanthemum flowers. Interior of gold nashiji lacquer. Eighteenth century.

Length, 81/2 inches; height, 5 inches.

\section{1-GOLD LACQUER BOX}

Decorated with figures of court nobles, royal flower-cart, pine trees and cherry blossoms rendered in powdered gold lacquer. Perfoated panels of diamond-shaped design; edged with lead. Interior of nashiji lacquer. 
Round-shaped, supported by four legs. Decoration of crest design, flowers and scrolls finely pencilled in gold lacquer. Eighteenth century.

Diameter, 7 inches; height, 7 inches.

1563-DAIMIO CABINET

Gold nashiji lacquer of highest quality. Containing nine small drawers, one of them furnished with ink-stone, silver water-holder and gold nashiji lacquer brush-holder. Decorated throughout with a most elaborate and beautifully executed design of bamboo trees, and leaves and crests in powdered and raised gold lacquer; some of the crests and bamboo leaves in overlay of leaf-gold. Chased silver lock, hinges and handles. Seventeenth century.

Length, 81/4 inches; height, 111/4 inches.

1564-GOLD LACQUER BOX

Lozenge-shaped, with four carved legs. Nashiji lacquer, decorated with design of ancient Japanese playing cards most minutely executed with various gold lacquers. Interior of beautiful gold nashiji. (Repaired.) Eighteenth century.

Length, 8 inches; width, 5 inches; height, 31/2 inches.

1565-SWEETMEAT BOX

Four sections. Aventurine lacquer. Decorated on the sides of each section with crests, diaper patterns, fish, and river scenes, carefully painted in gold lacquer of varied shades. On top of the cover are fan-designs on which are depicted various plants and grasses. Seventeenth century.

Height, 83/4 inches; width, 71/2 inches; depth, 7 inches.

1566-DESPATCH BOX

Gold nashiji, inlaid with kiri-kane gold lacquer. Cover has a gold lacquer decoration of leafy vines and fan design. Interior is of aventurine. Silver cord-holders. Seventeenth century.

Length, 9 inches; width, 21/2 inches; height, 2 inches.

1567-WRITING CASE

Black and gold lacquer. Richly embellished throughout in gold lacquer and mother-of-pearl incrustation, with equestrian figure, landscape, river view, and other designs after Unkoku Tōgeki, one of Japan's old masters, who died about 1600. Has ink-stone and a water-holder in design of a book, finely wrought in gold and silver. Early eighteenth century. 
Black lacquer. On the cover is a decoration in gold lacquer painting of cherry blossoms, willow tree and fence-design in finely powdered gold lacquer and with overlay of gold-leaf. On the reverse of cover is a decoration of plum blossoms, a river view and three family crests of Lord Nabeshima, executed in beautiful gold lacquer and partly inlaid with squares of cut leaf-gold upon a fine nashiji ground. Ink-stone with gold lacquer edge, and a gold water-holder with chased design of leafy scrolls. Eighteenth century.

Length, $91 / 2$ inches.

1569-WRITING CASE

Black lacquer. Cover is ornamented with a view of an autumn evening, flock of returning geese, rising moon, houses and trees executed in gold lacquers of many layers. On the reverse of cover are plum and bamboo trees and a fence in raised gold lacquer on a nashiji ground. Has a bronze water-holder and an ink-stone.

Length, 9 inches; width, 8 inches; height, 11/2 inches.

\section{5\%0-WRITING CASE}

Aventurine lacquer. Decorated on top of the cover with landscape and houses in raised gold of many layers over a nashiji lacquer. On the reverse of the cover and on the interior surface is a decoration of river view, pine grove and houses in gold lacquers of exquisite tone. Furnished with a silver water-holder with a decoration of chased plum blossoms, and an ink-stone, painted on the edges with gold lacquer. Early seventeenth century.

Length, 91/4 inches; width, 81/2 inches; height, 17/8 inches.

15\%1-WRITING CASE

Gold nashiji lacquer. Cover decorated with figure of Kikudoji seated on a rock gazing at a waterfall, painted in powdered and raised gold lacquer. On the reverse of cover are flying storks, and view of stream in raised and powdered gold lacquer. Has a bronze water-holder and an ink-stone. Seventeenth century. 
Gold nashiji lacquer. The decoration consists of a landscape and houses, and a bridge leading to a small island upon which a small summer house is erected. On the reverse of the cover is a decoration of ducks resting on rocks, in gold lacquers on a gold nashiji ground. Seventeenth century.

Length, 83/4 inches; width, 8 inches; height, 11/2 inches.

\section{3-WRITING CASE}

Black lacquer. The decoration consists of tree peonies beautifully painted in powdered and raised gold lacquer, upon an ishime nashiji ground. On the reverse of cover, and on a small tray within, is a decoration of wild chrysanthemums, and a faggotfence, pencilled in gold lacquers of various shades upon a beautiful nashiji ground. Has ink-stone and a gilded bronze waterholder.

$$
\text { Length, } 91 / 4 \text { inches. }
$$

15\%4-WRITING CASE

Black lacquer. Decorated on cover with kiri-leaves and Hōwō birds elaborately and richly painted in gold lacquers of many layers over a beautifully polished black lacquer. Reverse of the cover is of gold nashiji lacquer.

Length, 103/8 inches; width, 71/8 inches; height, 2 inches.

\section{5\%5-WRITING CASE}

Black lacquer of mirror polish. Gold lacquer decoration of plum blossom, pine trees, two tortoises and bamboo leaves, cloud forms and river view, rendered in a most artistic manner. Two small trays and a tablet within interior of nashiji lacquer. Eighteenth century.

$$
\text { Length, 93/4 inches; width, } 83 / 4 \text { inches. }
$$

\section{6-WRITING CASE}

Polished black lacquer. Cover ornamented with chrysanthemum flowers and fence, executed in gold lacquer over a beautiful black lacquer. The reverse of cover is decorated with Chinese landscape and waterfall exquisitely pencilled in fine gold lacquer over a nashiji ground. Edges are mounted with lead. Eighteenth century. 
Black lacquer, highly. polished. Decorated on the cover with deer and maple trees in the foreground, and distant mountains, exquisitely painted in raised gold lacquer. On the reverse of cover is a decoration of autumnal grasses in raised and powdered gold lacquer over a nashiji ground. Furnished with a bronze waterholder of circular shape, with crescent moon in silver, and an ink-stone.

$$
\text { Length, } 95 / 8 \text { inches; width, } 8 \frac{3}{8} \text { inches; height, } 2 \text { inches. }
$$

\section{8-WRITING CASE}

Black lacquer. Decoration of dragonfly, beans and vines, inlaid with mother-of-pearl, pottery and lead, and lacquered.

Length, 91/4 inches; width, 8 inches; height, 13/4 inches.

\section{9-WRITING CASE}

Aventurine lacquer. The cover decorated with landscapes, houses and waves skilfully depicted in gold lacquer of many layers over a gold nashiji ground. The reverse of cover is decorated with autumnal grasses, plants and pheasants over a nashiji ground. Early seventeenth century.

$$
\text { Length, 83/4 inches; width, } 81 / 8 \text { inches; height, 17/8 inches. }
$$

\section{0-WRITING CASE}

Gold nashiji lacquer. Painting of flowered vine in powdered and raised gold lacquers on top of the cover and on the interior surface. Reverse of the cover has a decoration of wild chrysanthemums and other flowers in gold lacquer. Furnished with an inkstone, a gold water-holder with chased design of shrubs and two small trays.

Length, $9 \frac{1}{2}$ inches; width, $8 \frac{3}{4}$ inches.

\section{1-WRITING CASE}

Aventurine lacquer of very high quality. Decorated on cover with views of pine and plum garden and a river scene carefully and elaborately executed in gold lacquer of various shades and layers. Reverse of the cover and the interior of the box are similarly treated in gold lacquer, with pine trees, waves and rocks on a beautiful aventurine lacquer background. Has a silver waterholder in design of a rabbit, and ink-stone. Seventeenth century. 
Gold nashiji of high quality. Chaste embellishment of chrysanthemum flowers exquisitely pencilled in powdered and overlaid leaf-gold of various tints. On the reverse of cover, and on the interior surface, is a decoration of waterfall, turbulent water, pine tree, plum blossoms and other designs artistically executed in gold lacquer. Has ink-stone and a water-holder in design of chrysanthemum flower and leaves, beautifully wrought in gold. Eighteenth century.

Length, 91/4 inches.

\section{3-WRITING CASE}

Gold nashiji lacquer. On the cover, painted in powdered gold lacquer, is a temple drum on which is perched a bird of paradise; pine and maple trees, camellia in bloom, rocks and river view. The reverse of cover and interior is of nashiji lacquer, with a gold lacquer decoration of brocade patterns, wave designs, pine needles and cloud forms, exquisitely pencilled. Furnished with ink-stone and a bronze water-holder. Sixteenth century.

Length, 83/4 inches.

\section{4-WRITING CASE}

Black and gold nashiji lacquer. The outer and inner surface covered with a beautiful embellishment executed in gold lacquers of various tones and mother-of-pearl inlays, consisting of boatingscene, landscape, cascade, wild geese in flight and other designs. Has ink-stone, and cloisonné enamel water-holder. Seventeenth century.

Length, $83 / 4$ inches.

\section{5-WRITING CASE}

Gold nashiji lacquer of high quality. Decorated on the cover with design of cherry trees in blossom, a box of wicker-work design, and a hillside, in raised gold and silver lacquer with leaf-gold overlay, most carefully executed over a beautiful aventurine lacquer background. The reverse of cover is embellished with a mass of floating maple leaves which are produced in leaf-gold overlay and in raised gold lacquer painting; view of a rivulet is treated in polished lacquer of silver and gold-tinted effect over a background of aventurine. The interior of the box is also decorated with a design of scattering maple leaves in leaf-gold and powdered gold lacquer. Furnished with a bronze water-holder in design of a maple leaf, gilded and chased, and an ink-stone. Seventeenth century. 
Gold lacquer in three styles. The upper part is closely covered with small squares of leaf-gold, the lower part is of beautiful powdered gold lacquer, and the central portion is covered with a dull powdered gold lacquer. On the cover in gold and silver lacquer painting is a decoration of pine tree, rising sun, pair of doves and a tiled wall. The decoration on reverse of the cover consists of two shells in relief, sprays of cherry blossoms, miniature views of ancient palaces, figures of court nobles and garden scenes finely executed in various lacquers on a beautifully finished gold nashiji lacquer ground. A tray inside has a sea design and various seashells in gold lacquer. Furnished with ink-stone and gilded bronze water-holder in design of a chrysanthemum. Date about 1630.

Length, $93 / 4$ inches.

\section{7-WRITING CASE}

Fine nashiji lacquer. Decorated on the cover with a flock of birds in flight and rocks, in raised and powdered gold lacquer, and inlaid with minute squares of cut leaf-gold. The bevelled edge is decorated with diaper patterns in gold, and the reverse of cover and a small tray and panel within are embellished with wave designs, shells and a stump of an old pine tree profusely painted in gold lacquer. Furnished with ink-stone and a finely wrought gold water-holder of cherry blossom shape. The decoration is after a painting by Yeinō of the Kanō school. Early seventeenth-century specimen.

Length, 9 inches.

\section{8-WRITING CASE}

Gold lacquer of beautiful quality. Superb embellishment throughout, consisting of autumn flowers, a stream, cloud forms and other designs, all of which are executed in a most skilful manner, in powdered and raised gold lacquer. Furnished with ink-stone and a water-holder, which is finely wrought in silver. Late seventeenth century.

Length, $91 / 2$ inches.

Gold and black lacquer. On the cover is a decoration of two Kashiwa-leaves, upon which are written in gold lacquer a Japan- 
ese poem; a writing brush is in relief; parts of Kashiwa-leaves are inlaid with mother-of-pearl and squares of leaf-gold, which are ornamented with silver pin-heads. The reverse of cover and interior are richly decorated with millet, sparrows and vines in raised gold lacquer and incrustations of mother-of-pearl. The ink-stone, which has a gold lacquer decoration, is signed Nakamura Yayemon. Silver water-holder in design of a Japanese hat. Seventeenth century.

Length, 91/2 inches.

\section{0—WRITING CASE}

Aventurine lacquer. Painting of a favorite subject, "the ten cranes" on the seashore, executed with artistic skill in raised gold and gold lacquer mosaics; the edge and corners are of gold lacquer mosaic over black lacquer. The reverse of the cover and interior of the box are decorated with a landscape scene, houses and flight of wild geese, with moon and clouds, treated in gold and silver over an aventurine lacquer ground. Furnished with a bronze water-holder in design of plum blossoms, and an inkstone with gold lacquer decoration over the edge. Seventeenth century.

Length, 9 inches; width, 81/2 inches; height, 17/8 inches.

\section{1-WRITING CASE}

Black and aventurine lacquer. Cover of gold lacquer with a garden scene and moon in gold lacquers of many layers. The reverse is decorated with a view of a seashore in raised and powdered gold lacquers over nashiji. Furnished with a gilded bronze waterholder in design of nuts and leaves and an ink-stone. Seventeenth century.

Length, 81/4 inches; width, 71/2 inches; height, 11/2 inches.

1592-WRITING CASE

Black lacquer. The cover is decorated with a pair of storks standing on a hill, incrusted in lead and mother-of-pearl and enhanced with gold lacquer painting. On the reverse of cover are branches of plum blossoms and pine needles in lead, mother-of-pearl and gold lacquer painting. It is said that the decoration is after a painting by the great master Tosa Mitsunobu, early part of the sixteenth century, and is the work of the noted artist in lacquer Kōyetsu. Furnished with ink-stone and a red bronze water-holder. 
Black lacquer of high quality and lustrous polish. The cover decoration consists of two folding screens, and a dog. The screens are executed in relief gold lacquer painting, the panels of same being embellished with landscàpe views in India ink effect, highly polished. On the six panels of one of the screens are swallows in flight and wistaria branches in polished gold lacquer over a black lacquer background. The dog is in silver inlay. The reverse of cover and interior of the box are decorated with a scene depicting a group of girls practising music, some playing a game of "Go" and others handling a screen. Painted in gold and colored lacquers of high polish, over a drab background.

Length, 81/8 inches; wiath, $71 / 8$ inches; height, 11/4 inches.

\section{4-WRITING CASE}

Black lacquer of high quality. Interior of fine gold nashiji. The cover is decorated with landscape and waterfalls, executed with great skill in raised and powdered gold of many layers and partly inlaid with mosaic gold and polished gold over a highly polished black lacquer. The reverse of cover is embellished with a waterfall, pine trees and rocks in powdered and raised lacquer, with gold mosaic filling. Furnished with a chased silver water-holder in design of pine trees, and an ink-stone, decorated on edges with gold lacquer. Seventeenth century.

Length, 91/2 inches; width, 9 inches; height, 2 inches.

\section{5-WRITING CASE}

Black lacquer of lustrous polish. Top of cover has a decoration of a flight of storks, pine grove and seashore in beautiful gold lacquer. Reverse of cover has a view of seashore, temple gate, pine trees and storks over a beautiful aventurine lacquer ground. The case is furnished with a lacquered ink-holder, lacquered brushholder, paper-piercer, silver water-holder in design of a stork, and ink-stone. Eighteenth century.

Length, 101/8 inches; width, $91 / 4$ inches; height, 13/4 inches.

\section{6-WRITING CASE}

Fine nashiji lacquer. On the cover is a beautifully rendered view of the imperial garden, painted in gold lacquers of various shades; a representation of a bamboo fence is in gold inlays. On the reverse of cover and on the interior surface is a decoration of landscape, storks, pine, wave designs and sea view exquisitely painted 
in powdered and raised gold lacquers. Furnished with ink-stone, silver water-holder in design of a miniature kettle, and gold nashiji lacquer brush-holder. An extraordinary example of the highest type of regal magnificence. Early seventeenth century.

Length, $93 / 4$ inches.

1597-WRITING CASE

Gold and silver lacquer. Decorated on top of cover with a mass of chrysanthemum flowers in many layers of gold over a silver and a gold lacquer ground. Reverse of the cover and the interior of the box are ornamented with a garden and river view in gold lacquer on an aventurine ground. Has a silver water-holder and ink-stone. Seventeenth century.

Length, 9 inches; width, 81/2 inches; height, 17/8 inches.

1598-WRITING CASE

Aventurine lacquer. Cover decorated with pine grove, river scenes and group of storks, executed in raised and powdered gold lacquer, over a gold nashiji. The reverse of cover is painted with river scene, trees and group of mandarin ducks in raised gold lacquer on a nashiji ground. Interior surface of box is of fine nashiji. Seventeenth century.

Length, 93/8 inches; width, $8 \frac{1}{2}$ inches; height, 21/4 inches.

1599-WRITING CASE

Aventurine lacquer of unusually fine quality. Decorated witr. designs of fans inside of which are pines, plum flowers and chrysanthemums in exquisite gold lacquer over a beautiful background of aventurine. Reverse of the cover has a decoration of bamboo and camellia japonica. The interior is covered with a beautiful aventurine lacquer. Furnished with a silver water-holder in design of double fan; and an ink-stone. A very costly specimen of the seventeenth century.

Length, 10. inches; width, 9 inches; height, 2 inches.

\section{0-BEAUTIFUL LACQUERED CABINET}

With drawers and enclosures. Of mirror-black quality. The decoration represents scenes from the ancient No dance. The various characters of the play are painted in exquisite gold lacquers of various tones. On the top panel are a fan design and pine tree, most carefully rendered in finely powdered and raised gold lacquers. The decoration throughout is executed with skill and great precision. Mountings of shakudo and bronze. 
Representing Lady Tokiwa, mother of Yoritomo (a great warrior of the fifteenth century). Patterns of costume carefully painted in gold lacquer on body color of brownish yellow.

Height, 121/4 inches.

\section{2-PRESENTATION BOX}

In two sections. The upper section contains five boxes, the centre one in diamond shape, and those surrounding of convex shape, each being decorated most elaborately with designs of brocades and flowers in gold and red lacquer. The outer surface of the box is richly embellished with reeds and grasses, which are inlaid with lead and mother-of-pearl and artistically painted with gold lacquer of various shades and layers. Interior is of gold nashiji of high grade.

Length, 91/2 inches; width, 81/4 inches; height, 41/2 inches.

\section{3-DAIMIO SCROLL BOX}

Powdered gold lacquer of exceedingly fine quality. The cover and four sides have a decoration of numerous medallions, within which are peonies, wistaria in flower, lotus flowers, bamboo and pine trees, kiri-flowers, plum blossoms, camellias, willow trees, chrysanthemums and grape vines; all rendered in gold lacquer of two shades on a background of nashiji and brown lacquers. Silver cord-holders. Early eighteenth century.

Length, 19 inches; width, 51/2 inches.

\section{4-DAIMIO MANUSCRIPT BOX}

Gold nashiji lacquer. On the cover is a decoration of landscape, water view, ducks, camellia in flower, pine trees and mountain scenery, beautifully pencilled in powdered and raised gold lacquer, with overlays of leaf-gold and leaf-silver. The reverse of cover is decorated with a landscape, pine trees, pheasants and wild flowers, elaborately rendered in powder and raised gold. Seventeenth century.

Length, 161/2 inches; width, 131/2 inches.

\section{5-SWEETMEAT BOX}

In four sections. Aventurine lacquer. Interiors of Chinese mansions and garden scenes, carefully depicted in variously shaded gold lacquer over a gold nashiji. On top of cover is a view of a porch of a mansion with group of figures, in gold lacquer. Eighteenth century.

Height, 85/8 inches; width, 7 inches; depth, 63/8 inches. 
Of beautiful, lustrous quality. Exterior is decorated with " pineneedles," executed in fine powdered gold lacquer. Reverse of the cover and interior of the box are lavishly decorated in gold lacquer with waterfalls, mountain scenery and turbulent water on a ground of costly nashiji lacquer. Has silver cord-holders in design of Japanese character signifying "Ten thousand generations."

Length, 10 inches; width, 4 inches; height, 23/4 inches.

\section{0\%--JAPANESE LACQUER INDIVIDUAL DINNER-TABLE}

Round, with three legs. Red lacquer centre panel with chrysanthemum flowers painted in gold lacquer.

Diameter, 12 inches; height, 4 inches.

\section{8-PAIR CHINESE CINNABAR LACQUER STANDS}

Octagonal-shaped, with eight turned legs. On the top is a carved ornamentation of Hotei and his companions. Panels and shoulder borders have a carved decoration of birds and flowers.

Height, 11 inches; diameter, 12 inches.

\section{9-MANUSCRIPT BOX}

Aventurine lacquer of high grade. The decoration on obverse and reverse of cover, and on the four sides, consists of fan-designs, inside of which are depicted landscapes, houses, flowers and birds, most accurately and minutely executed in gold lacquer of many layers; the reverse parts are in gold nashiji. The edges of the box are covered with lead. Costly specimen of seventeenth century. Height, 51/2 inches; length, 13 inches; width, 101/4 inches.

\section{0-DAIMIO INDIVIDUAL DINNER-TABLE}

Gold nashiji lacquer. Decorated outside with butterflies, chrysanthemums and peony flowers in gold and silver lacquer. Eighteenth century.

Diameters, 161/2 and 16 inches; height, 10 inches.

\section{1-PERFUME BOX}

In design of a biwa (musical instrument). Gold lacquer, with teakwood handle. Decoration of autumnal grasses and butterflies and other designs in gold lacquer and mother-of-pearl. Eighteenth century. 
Nashiji lacquer. Decoration of bamboo, key patterns, plum flowers, pine trees and bamboo leaves in gold and silver lacquers. Inside is lined with gold decorated paper.

Length, 151/4 inches; width, 121/2 inches.

\section{3-SUPERB BOTTLE-SHAPED VASE}

The outer surface completely covered with a powdered gold lacquer of high quality and lustrous surface. The decoration, which is exquisitely executed, consists of chrysanthemum flowers, gourds, grasshoppers, diaper patterns and other designs, painted in fine gold lacquer of various shades and inlaid with minute squares of cut leaf-gold. This specimen is one of a pair, originally made by order of the imperial Japanese government for the centennial exposition at Philadelphia in 18\%6, and illustrates the highest perfection of art in modern lacquer-work. Has stand of cinnabar lacquer, decorated with an elaborate carving of butterflies, storks, peony flowers and leafy scrolls.

Height, 24 inches with stand.

\section{4-DAIMIO MANUSCRIPT BOX}

Aventurine lacquer of the finest quality covering the exterior and interior surface. The artistically executed decoration consists of mountain scenery, flowers, pine trees, plum blossoms and bamboo leaves in powdered and raised gold lacquer and inlays of cut leafgold. The decoration throughout is profuse and of extreme richness. Boxes of this class were made for the exclusive use of court nobles of Old Japan. Seventeenth century.

Length, 17 inches; width, 131/2 inches.

\section{5-SCROLL BOX}

Gold nashiji lacquer of high quality. The decoration on cover is a pair of storks, a tortoise on rock, wave designs and cloud forms beautifully executed in raised gold lacquer, partially overlaid with leaf-gold and ornamented with silver pin-heads. On the interior surface are seven family crests of a feudal lord of old Japan, painted in gold lacquer on a fine gold nasihji ground. Chased silver cord-holder; red silk cord. Seventeenth century. 
1616-BOTTLE-SHAPED VASE

Cinnabar lacquer. Elaborate decoration of peony flowers and leafy scrolls most carefully carved. Chinese characters in gilded bronze inlaid on four sides. Ch'ien-lung period, 1736-1796. Carved teakwood stand.

Height, 14 inches.

1617-MANUSCRIPT BOX

Black lacquer. Gold lacquer painting of plum blossoms, nightingales and a faggot fence beautifully executed in powdered and raised gold and silver lacquers. Reverse of cover is decorated with pine trees and tortoises. Interior is of nashiji lacquer in cloud forms. Latter part of eighteenth century.

Length, 16 inches; width, 121/2 inches.

1618-TALL BLACK LACQUER STAND

Supported by four turned legs with platform underneath. Landscape decoration in etched workmanship on top and on the platform. Old Chinese specimen.

Length, 19 inches; width, 141/2 inches; height, 25 inches.

1619-BLACK LACQUER CABINET

Containing seven drawers. Gold lacquer decoration of cherry blossoms and willow trees on top and sides; front of the drawers has a decoration of eagle and pine tree. Pencilled in gold lacquer. Length, 211/2 inches; width, 13 inches; height, 193/4 inches.

1620-PICNIC CASE.

Black lacquer. Consisting of a sweetmeat box with four compartments, two sake bottles, an oblong tray and a shallow cake box. The embellishment throughout is of a rich character painted in fine quality of gold lacquer, and in mother-of-pearl and lead incrustations. The decoration consists of flowering plants, blossoms, fan-shape panels, birds and other designs. Signed, Kōrin. Length, 111/4 inches; height, 101/4 inches.

1621-DAIMIO MANUSCRIPT BOX (ONRIOSHIBAKO)

Black and speckled gold lacquer, with an elaborate decoration of bold pine and cherry trees painted in powdered gold lacquer, and in cut leaf inlays. On the reverse of cover is a landscape scene, with thatched houses, a river view and other designs most carefully executed in gold lacquer on a fine nashiji ground. Seventeenth century. 
In five sections. Gold nashiji lacquer of high quality. On top and on the four sides is an elaborate design of peony flowers in powdered and raised gold lacquer; some of the flowers and leaves are overlaid with leaf-gold. Interior is completely covered with red lacquer of deep shade. Eighteenth century.

Height, 163/4 inches; width, 111/4 inches.

\section{3-MANUSCRIPT BOX}

Brown lacquer in imitation of wood grains. Decorated with wild chrysanthemum and a crescent, in powdered and raised gold lacquer; the moon being overlaid with silver leaf. The inner surface is decorated with cherry and plum blossoms in polished gold lacquer on a ground of gold speckles on black lacquer. Eighteenth century.

Length, 15 inches; width, 11 inches.

\section{4-LACQUER BOX}

Entire surface of pale yellow lacquer. Decorated on top and sides with birds and floral design, Chinese coins, and butterflies in gold, silver, red and green lacquers. Cover of inner compartment has engraved decoration of Chinese landscape with border decoration of various emblems. Inner compartment of pewter. Brass handles and lock. Chinese brocade cover. Fine old Chinese specimen.

Length, 131/2 inches; width, 10 inches; height, 9 inches.

1625-DAIMIO SECTIONAL BOX (ONJUBAKO)

In five sections. With a silver and gold outer frame forming handle. Gold nashiji lacquer decorated with fan designs and various flowers, landscapes, grasses, birds and fishes beautifully painted in gold lacquers of various shades. Early eighteenth century.

Height, 14 inches; width, 8 inches.

1626-CINNABAR LACQUER CABINET

With drawers and enclosures. Elaborate and artistically carved ornamentation of landscape scenery, figures, symbols and other designs. Engraved brass mountings. K'ang-hsi period. 1662. 
Four-cornered and with four curved legs with platform underneath. Carved decoration of peony flowers and cherry blossoms elaborately executed in red and green lacquers. Signed by the famous artist Zokoku.

Length, 13 inches; width, 101/2 inches; height, 183/4 inches.

\section{8-PICNIC BOX}

Gold nashiji lacquer. Consisting of an outer case, sweetmeat box with four sections, two pewter sake bottles, one gold nashiji sake saucer, one square tray, and a small oblong tray. Decoration of large chrysanthemums and a stream painted in powdered gold lacquer with slight inlays of lead. Silver handle on top. Eighteenth century.

Length, 131/2 inches; height, 13 inches.

\section{9-DAIMIO WRITING TABLE}

Gold nashiji lacquer of very high quality and rich embellishment. The decoration which is beautifully executed in heavy gold lacquer, consists of palace garden scenes; plum tree in blossom, nightingales, pine trees, rocks and other designs, some of which are inlaid with minute squares of cut leaf-gold. Mountings of gilded metal, chased ornamentation. An elegant specimen of the seventeenth century.

Length, 23 inches; width, 133/4 inches; height, 5 inches.

\section{0-IMPERIAL CHINESE CAKE BOX}

Cinnabar lacquer. The entire surface covered with an elaborate decoration, consisting of branches of peonics, birds of paradise, dragons amid cloud forms and fire emblems, pursuing the Pearl of Omnipotence, and numerous borders, all beautifully carved with the utmost skill. Probably early part of K'ang-hsi.

Diameter, 12 inches.

\section{1-DAIMIO MINIATURE PALANQUIN (KAGO)}

Gold nashiji lacquer of high quality. Decorated with crests of family of Shimadzu, ex-daimio of the province of Satsuma. The mountings are of gilded bronze with chased decoration of floral vines. 
Black lacquer. Decorated with a design of crests and leafy scrolls in gold lacquer. Have extra trays inside. Chased brass handles and mountings. Four red silk cords. Eighteenth century. Length, 231/2 inches; width, 161/2 inches; height, 141/2 inches.

1638-DAIMIO SADDLE AND STIRRUPS

Fine quality of nashiji. Decoration in gold lacquer of lion and peonies. Examples of Massanao, dated seventh year of Kwanbun (166\%).

1634-DAIMIO SADDLE

Gold lacquer. Decoration of Hōwō birds on a black lacquer ground. Gold nashiji lacquer finish underneath. Dated fifth year of Kwanbun (1665).

\section{5-BLACK LACQUER STAND}

Decoration of swallows and dragon-flies in mother-of-pearl of various hues, inlaid and painted with gold lacquer.

Length, 141/12 inches; width, 91/2 inches; height, 51/4 inches.

\section{6-FOUR LACQUER PANELS}

Decorated with design of storks and plum trees in blossoms, in gold and silver lacquer upon a leather-like background. The two larger are decorated with birds and camellia trees in blossom painted in relief gold lacquer.

Length, 11 and 9 inches; width, 5 and 6 inches.

1637-TALL STAND

Red nara lacquer. Openwork panels below the top shelf mounted with bronze.

$$
\text { Height, 181/4 inches; diameter, } 91 / 2 \text { inches. }
$$

1688-TEMPLE STAND

Gilt decoration of carved and gilded wood; floral design.

Length, 161/2 inches; width, 43/4 inches; height, 41/2 inches.

\section{9-BROWN LACQUER PANEL}

Decorated with a fan design which contains landscape and houses rendered in powdered and raised gold lacquer. By Masatoshi. Seal mark. 
Highly polished. Painting of lotus leaves and a heron rendered with artistic skill in two shades of green lacquer and enriched by gold pencilling.

Height, 15 inches; width, 111/2 inches.

1641-PAIR OF LACQUER PANELS

Containing design of flowers and basket and flower-pot and plants in high incrustation of carved and tinted ivory and mother-ofpearl.

$$
\text { Height, 16\% inches; width, } 12 \text { inches each. }
$$

\section{2-PAIR CHINESE LACQUERED FRAMES}

Gold lacquer decoration of flowers and leaves. Carved ornamentation of peony flowers lacquered in gold and red.

Height, 353/4 inches; width, 20 inches.

1643-CABINET SWORD RACK

For five swords. Keyaki-wood. Has three drawers in base. Length, 16 inches; height, 16 inches.

1644-SWORD RACK

For three swords. Black lacquer. Decoration of storks, plum blossoms, diapers and arabesques in gold lacquer.

Height, 15 inches; length, 18 inches.

\section{5-SWORD RACK}

Gold nashiji lacquer. Decorated with crests and floral design in gold lacquer. Silver mountings. To hold three swords.

Height, 15\%3 inches; length, 221/2 inches.

\section{6-CABINET SWORD RACK}

For three swords. Cabinet contains five small drawers. Made of teakwood and elaborately decorated with raised and powdered gold lacquer. Mountings of silver wrought in design of feathers.

Length, 17 inches; width, 71/4 inches; height, 161/4 inches.

1647-CABINET SWORD RACK

Of keyaki-wood. Bronze mountings.

Length, 141/4 inches; width, 81/2 inches; height, 14 inches. 
For three swords. Black lacquer, with crests in gold lacquer painted inside of four panels.

Length, 223/4 inches; height, 15 inches.

1649-SWORD RACK

Black lacquer. Large crests of the Toku-gawa family painted in front and on the reverse in gold lacquer.

Length, 231/2 inches; height, 131/4 inches.

1650-SWORD RACK

For two swords. Black lacquer. Decorated in gold lacquer with crest designs. Length, 21 inches; width, 131/2 inches; height, 7 inches.

1651-SWORD RACK

Green and brown lacquer. Mother-of-pearl inlaid in nashiji style. Length, 15 inches; height, 131/4 inches.

1652-FOLDING SWORD RACK

Keyaki-wood. For four swords. Decoration of two gourds in openwork.

Length, 15 inches; height, 103/4 inches.

1653-FOLDING SWORD RACK

Keyaki-wood. For five swords. The back panel has an openwork decoration.

Length, 181/4 inches; height, 101/2 inches.

1654-BLACK LACQUER SWORD RACK

For three swords. Decoration of crests in gold lacquer.

Length, 231/2 inches; height, 153/4 inches.

1655-FOLDING CABINET SWORD RACK

For three swords. Japanese kiri-wood. Has three drawers, with

bronze locks and mountings.

Length, 14 inches; height, 24 inches.

1656-SWORD RACK

For three swords. Decoration of crests in gold lacquer on a black ground; openwork panel.

Length, 211/2 inches; height, 121/2 inches. 
165\%-SWORD RACK

For three swords. Japanese keyaki-wood. Panel decoration of carved designs of bird of paradise, plum blossom and waterfall.

Length, 221/4 inches; height, 141/4 inches.

1658-SWORD RACK

For four swords. Japanese keyaki-wood. Stained and polished. Length, 21 inches; height, 141/4 inches.

1659-SWORD RACK

For three swords. Japanese kiri-wood. Stained and polished. Length, 201/2 inches; height, 133/4 inches.

1660-SWORD RACK

For three swords. Japanese kiri-wood. Stained and polished. Openwork panel.

Length, 20 inches; height, 131/2 inches.

1660a-TALL PEDESTAL TABLE

Japanese. Lacquered ornamentation of bamboo sparrows and other design.

Height, 30 inches; width, 18 inches.

1661-JAPANESE SIDE TABLE

Finely lacquered ornamentation.

Height, 30 inches; length, 291/2 inches.

1661a-JAPANESE PEDESTAL TABLE

Finely carved black lacquer; red lacquer panels inserted in top and base.

Height, 28 inches; length, 21 inches.

1662-JAPANESE PEDESTAL TABLE

Tall form. Black lacquer finish, with sparrows, bamboo and other designs in gold and colored lacquer.

Height, 301/2 inches:

1663-ELABORATE ANTIQUE JAPANESE PEDESTAL TABLE

Two monster dragons supporting a table of cloud form design; on a base which is carved with a Greek fret band. The whole skilfully carved in wood and decorated with gold and red lacquers of low tones.

Height, 381/2 inches; length 63 inches. 
This unique screen was from the Court of Audience in the Summer Palace and constituted a part of the throne used by the Emperors of China in giving their audiences. It was stolen by Chinese after the looting by the allied forces of England and France in 1860. It is a great misfortune that the chair belonging to it is not now with it. This screen formed the background of the throne; the chair was of the same width as the middle panel.

Its construction was during the period of Ch'ien-lung, and in every respect represents the very highest standard of Chinese Art in lacquer. In the panels will be found a reproduction of the bold designs and treatment of the Ming period. All the magnificent detail carving around them, including the grand representation of the imperial five-clawed dragon at the top, is of that exceeding fineness so characteristic of the period of the Ch'ien-lung school.

Height, 8 feet $41 / 2$ inches; length, 8 feet 111/4 inches. 


\section{SEVENTH AFTERNOON'S SALE}

WEDNESDAY，JANUARY 24TH， 1906

\section{JAPANESE BRONZES, ARTICULATED IRON AND OTHER METAL WORK}

\section{AT THE AMERICAN ART GALLERIES}

BEGINNING AT 2.30 o'CLOCK

1665-TWO SMALL OKIMONOS

(a) Coiled serpent.

(b) Monkey. Both wrought in yellow bronze.

1666-OVIFORM MINIATURE VASE

Japanese bronze, inlaid with gold.

1667-JAPANESE SEAL MARK

Bronze figure of God of Wisdom.

1668-TWO SMALL OKIMONOS

(a) Gilded brass kylin.

(b) Fabulous animal, wrought in bronze.

1669-TWO OKIMONOS

Old Japanese bronze.

(a) Frog with lotus leaf.

(b) Crudely modelled crab.

1670-MINIATURE SHRINE

Pagoda shape, wrought in gilt brass, containing small crystals.

16\%1-SMALL INCENSE BURNER

Japanese bronze. Semi-globular shape on tripod of slender supports. 
1672-TWO COVERED BOXES

Basket-work, in copper; repoussé lids of fruit and shell designs. Japanese.

1673-JAPANESE MIRROR

Bronze, with silver face. On the reverse an inscription in relief. 1674-JAPANESE CALENDAR

With signs of the zodiac. Wrought in various metals. 1675-SMALL OKIMONO

Figure of Daikoku in Japanese silver bronze. Signed, Hōzan, tsukuru.

1676-SMALL OKIMONO

Old Japanese bronze. Equestrian figure of a warrior.

1677-SMALL TRIPOD CENSER

Japanese bronze, inlaid with gold and silver.

1678-SMALL INCENSE BURNER

Japanese yellow bronze. Globular shape on tripod and with openwork cover and loose ring handles.

1679-INCENSE BURNER

Design of a quail. In Japanese yellow bronze. Signed by Kamejō, a woman artist of Nagasaki.

1680-TWO SMALL OKIMONOS

Japanese bronze rabbits.

1681-SMALL OKIMONO

Daikoku standing on a rice bale. Old Japanese bronze.

1682-SMALL OBLONG INCENSE BURNER

On support formed by figure of Japanese children. Old Japanese bronze. Damascened ornamentation in silver and gold of Hōwō bird and floral crests.

1683-LIBATION CUP

Old Japanese bronze; finely inlaid with silver; Greek fret patterns and panel designs partially gilded. Lined with silver. 
1684-SMALL INCENSE BURNER

Old Japanese bronze. Oblong shape, with rudimentary handles.

Ornamented with two figures modelled in relief and silvered. Teakwood stand.

1685-SMALL WATER KETTLE

Old Japanese bronze. Dog Foo in relief casting. Rich golden brown patina.

1686-OKIMONO

Old Japanese yellow bronze. Figure on horseback.

168\%—SAKE BOTTLE

Gourd-shaped. Old Japanese yellow bronze; repoussé ornamentation and incised symbols.

1688-SMALL PERFUME BURNER

Old Japanese bronze. Dragons and water designs in relief casting and openwork. Inscription under foot signifying " everlasting treasure." Tall teakwood stand.

1689-SMALL OKIMONO

Japanese boy with mask. Old Japanese bronze.

1690-SMALL BRONZE AND WOOD GROUP

Representing Buddha and his disciples. Old Japanese.

1691-GLOBULAR INCENSE BURNER

Brass, coated with a copper-red patina. Openwork cover. Teakwood stand.

Height, 3 inches.

1692-JAPANESE BRONZE BRAZIER

Quadrilateral form on four feet of palm-leaf design. Imperial dragons on cloud forms in relief casting on an incised ground. By Seimin and signed, "Dai Nippon Bunsei neu Seimin iru." Dated, Bunsei, $181 \%$.

Height, $3 \frac{1}{2}$ inches.

1693-LEAF-SHAPED TRAY

Old Japanese bronze.

1694-PAIR OKIMONOS

Dog Foo. Old Japanese bronze; rich brown patina. 
Figure of demon. Old Japanese bronze; mottled red and brown patina.

1696-OKIMONO

Fawn. Old Japanese bronze; finely modelled.

1697-PERFUME BURNER

Old Japanese yellow bronze. Globular shape on high foot. Dragon and wave designs in relief casting; leaf shape panels incised.

1698-BRONZE WATER BOTTLE

Fabulous animal. Old Japanese.

1699-JAPANESE BRONZE OKIMONO

A life-like crab. By Tei-jō.

1700-LIFE-LIKE TURTLE

Finely cast in bronze. Gold seal mark of Isshinsai.

1701-JAPANESE IRON INCENSE BURNER

Globular shape on tripod. Ornamentation of carp and water scene in high and low relief. Metal-work frog surmounting lid. By Matsuwō, a great iron-worker of the nineteenth century.

Height, $51 / 2$ inches.

1702-SMALL V $\dot{A} S E$

Old Japanese bronze. Bottle-shaped, with tall quadrangular neck, which is ornamented with relief castings. Golden-brown patina. Teakwood stand.

Height, $5 \frac{1}{2}$ inches.

1703-BRONZE GLOBULAR BOX

Old Japanese. Inlaid with silver and gold wires with crest and foliated patterns. In Hindoo style.

Diameter, 4 inches.

1704-INCENSE BURNER

Old Japanese bronze. Lotus leaf design. Fine brown patina.

1705-OLD JAPANESE BRONZE IDOL

The "Six-arm Buddha," seated on a bronze base. 
1706-OLD JAPANESE BRONZE OKIMONO

A priest and tiger.

170\%-TWO SMALL INCENSE BURNERS

Oblong shape on four tall, slender legs. Old Japanese bronze inlaid with fine silver wires. Teakwood stand.

1708-SMALL INCENSE BURNER

Old Gorosa bronze. Globular shape with openwork cover in designs of dragon and cloud forms. Fine patina.

1709-JAPANESE OKIMONO

Group of shells wrought in bronze.

1710-BRONZE STATUETTE

Figure of a running coolie. Old Japanese.

1711-BRONZE INCENSE BURNER

Old Japanese. Design of Dog Foo.

Height, $51 / 2$ inches.

1712-BRONZE OKIMONO

Kneeling figure of Daruma (one of the Buddhist saints) making

faces. Mottled red and brown patina.

Height, 41/2 inches.

1713-TRIPOD INCENSE BURNER

Old Japanese bronze. Mottled red and brown patina. Teakwood stand.

Height, 5 inches.

1714-JAPANESE INCENSE BURNER

Of rich-toned brown bronze representing two quails, one of which is sitting flat on the ground turning its head to the left; the other, upright, is resting against the first with its raised head as if listening to some sound of danger. The group is exquisite and graceful and the expression of life is remarkably good. The patina is light and dark and shines brilliantly. Eighteenth century.

Height, $53 / 4$ inches.

Exhibited at a Loan Exhibition, National Academy of Design, 1893.

1715-BRONZE LIBATION CUP

Peach-shaped. Dragon and cloud forms in relief casting.

Length, $5 \frac{1}{2}$ inches. 
Old Japanese red bronze. Fishes, animals and wave designs, in relief casting and partially gilded.

Length, 4 inches.

1717-INCENSE BURNER

Semin bronze. Globular shape, with dragon handles; dragons and various borders in relief casting. Dog Foo ornament surmounting cover.

1718-INCENSE BURNER

Old Japanese red bronze. Design of a rabbit with peach fruit.

Height, $4 \frac{1}{2}$ inches.

1719-OLD JAPANESE BRONZE KORO

Globular shape, with figure supports and fungi handles. Fine ornamentation in relief casting. Covers surmounted by a Dog Foo and brocade ball. Brown patina.

Height, 5 inches.

1720-BRONZE OKIMONO

Old Japanese. Woman holding incense burner. With metal-work stand.

Height, 51/2 inches.

1721-OLD JAPANESE BRONZE OKIMONO

Phœuix and Hōwō bird on an openwork base representing cloud forms.

Height, 5 inches.

1722-SMALL OVIFORM VASE

Old Japanese yellow bronze. Dog Foo chasing brocade balls, cast in high relief on shoulder. Fine mottled patina. Teakwood stand.

Height, 5 inches.

1723-BRONZE STATUETTE OF BUDDHA

Seated on a lotus flower, and with an openwork brass halo. Stand in design of lotus leaves.

Height, 6 inches.

1724-JAPANESE BRONZE INCENSE BURNER

Life-like quail. Cast in yellow bronze. Seal mark of Kamejō, a woman artist of Nagasaki.

Height, 5 inches.

1795-JAPANESE BRONZE OKIMONO

A " turtle of longevity," supporting tree stump, designed to hold a crystal ball. Incised and inlaid with silver wires. 
1726-SENTOKA BRONZE INCENSE BURNER

Lozenge shape on four tall feet. Coated with a rich patina. Sixcharacter mark: Ta Ming Hsüan-te nien chih. Has carved teakwood openwork cover with jade ornament and teakwood stand.

Height, 51/2 inches.

1797-BEAKER-SHAPED VASE

Japanese yellow bronze. Horses and panel designs in high relief.

Mottled patina. Signed underneath foot, Nakawo Munesada. Height, 51/2 inches.

1728-OLD JAPANESE BRONZE OKIMONO

Fisherman astride a toad fish. Signed by Jö-un.

Height, 51/2 inches.

1729-BRONZE OKIMONO

Dog Foo. Old Japanese. Carved teakwood stand.

Length, 4 inches.

1730-COPPER BOX

Circular shape; repoussé cover. Hotei, the "God of Plenty," peeping out of his treasure bag. Old Japanese.

1731-JAPANESE TEA JAR

Surface of finely woven bamboo over pewter. Signed by "Fuku," stamped on the base.

17\%2-SAKE KETTLE

A cocoanut shell mounted with brass. Old Japanese.

1738-SMALL INCENSE BURNER

Old Japanese copper-bronze, finely inlaid with gold and with gilded ornaments and bands; the cover of openwork chrysanthemum design. Teak stand.

1734-OLD JAPANESE RED BRONZE BOX

Circular shape. Repoussé cover. Hotei, the "God of Plenty," peeping out of his treasure bag.

1735-OLD JAPANESE BRONZE VASE

Fisherman with large carp. Rich brown patina. 
Globular-shaped on tripod. Rudimentary handles on shoulder; figure of Dog Foo surmounting cover. Coated with a mottled red and brown patina.

Height, 5 inches.

\section{3\%-BRONZE OKIMONO}

Old Japanese. Design of stump of tree with vine, in relief casting and chiselled.

Height, 5 inches.

\section{8-BRONZE INCENSE BURNER}

Old Japanese. Jar-shaped, supported by figures of three monkeys. Incised band of archaic design; rich mottled brown patina.

Diameter, 5 inches.

\section{9-PAIR JAPANESE BRONZE VASES}

Birds, flowers and other designs in relief casting. Signed by Nabenaga.

Height, 5 inches.

\section{0-A WOUNDED BIRD}

Japanese bronze of the eighteenth century. The expression of this wounded bird is so natural that we are convinced it is the work of a great artist-to us unknown.

Length, 9 inches.

Exhibited at a Loan Exhibition, National Academy, 1893.

1741-JAPANESE BRONZE OKIMONO

A fabulous bird. On carved wood stand.

Height, 6 inches.

\section{2-OLD JAPANESE BRONZE INCENSE BURNER}

Fruit-shaped, mottled red patina. Mark under foot, "Ta Ming Hsüan-te nien chih."

$$
\text { Height, } 6 \text { inches. }
$$

\section{3-JAPANESE BRONZE FLOWER VASE (HANAIKE)}

Period: seventeenth century. This vase imitates in form a Tsurube (wooden bucket, used to draw water from the well), is of brown bronze; a transversal piece crosses at the top on the inside, to which is attached a ring, which serves to hang the vase. The whole decoration consists of lines imitating the veins of old wood. It is most successfully handled in a realistic style. The dark-brown patina, clouded with red, shining with dull, mysterious light, augments its beauty. 
1744-PAIR CYLINDRICAL VASES

Old Japanese bronze. Ornamented with a bold dragon in relief casting and partially gilded. Signed by Bi-rei-in.

1745-SMALL BRONZE CANNON

Height, 51/2 inches.

Old Japanese. Handles on sides and trunnions in shape of animal heads. The surface rough and worked over with a star-shaped diaper pattern.

Length, $5 \frac{1}{2}$ inches.

1746-JAPANESE BRONZE OKIMONO

Group of three storks; designed as a stand for a crystal ball.

Height, $5 \frac{1}{2}$ inches.

1747-OLD JAPANESE BRONZE INCENSE BURNER

Ornamented with archaic designs and covered with rich brown patina. Teakwood stand.

1748-TWO SAKE KETTLES

Height, 51/2 inches.

(a) White metal, covered with a copper-red patina and incised.

(b) Hammered Chinese bronze, with landscape and inscription incised and inlaid.

1749-OCTAGONAL BOX

Gorosa bronze. Finely engraved ornamentation of cherry blossoms, bamboo and tree peonies.

1750-INCENSE BURNER

Old Japanese yellow bronze. Design of a seated dog.

Height, 6 inches.

1751-JAPANESE BRONZE INCENSE BURNER

Period: Man-yen, about 1860. Of yellow bronze, square, with two handles and four feet; is decorated with dragons on a fretted background. On each face the dragon is in a different position, and is surrounded with flames and cloud forms. Each dragon is full of movement and powerful in expression. The heavy and light strokes are so combined as to convey strength to the animal from head to tail. The feeling of the skin and the muscular contraction are as well expressed as in a work of Seimin. The background is a fret, in which the male and female principle are interlocked. In the centre of the bottom is found the rectangular mark of Somin, of Tokio, pupil of Seimin, or, to speak more truly, the continuator of his school.

Height, 65/8 inches; $61 / 4$ inches square.

Exhibited at a Loan Exhibition, National Academy of Design, 1893. 
Japanese. Fifteenth century. A group of two figures back to back representing two of the four Shitanno, Buddhist divinities for the protection of the four cardinal points. Each one holds in his mouth a pair of strings which, passing under their arms, are joined together. One of them holds in his raised and clasped hands the sacred wheel, in gold; the other, in his clasped and lowered hands, the sacred spear Dokko. Their costume consists of a helmet and flowing robe with devil-head epaulettes, the uniform of the generals of Hang, in which the Chinese represent the Buddhist military deities. The two Touno stand on a pedestal simulating an inverted lotus leaf. The yellow bronze, completely darkened by the smoke of the perfume, is heavily amalgamated with gold, whereas the eyes, the teeth, and the jewels are of pure gold. This object is the cover of an incense burner and is a masterpiece of Japanese bronze, under the shogun Yoshimaysa, who having had frequent relations with Ming, endeavored to surpass Chinese art with that of Japan. These statuettes show to what extent sculptural art was developed at that time. The strength displayed in the face alone demonstrates to what height that art had reached. In this costume, though so severe, there is no lack of elegance; observe what nobility it imparts to the attitude. This sculpture is probably the work of one of two master artists of that period-"Unkei," or his son "Tonkei."

Loan Exhibition, National Academy of Design, 1893.

Height, $4 \frac{7}{8}$ inches.

175.3-SMALL BRONZE VASE

Old Japanese. Beaker-shaped, with dragon handles on cover. Brown patina.

Height, 6 inches.

1754-OLD JAPANESE BRONZE BAS-RELIEF

Buddha seated on a lotus flower.

Diameter, 6 inches.

1755-JAPANESE RED COPPER BOX

Low circular shape. Top of lid beautifully ornamented, with sprays of chrysanthemum and cherry blossoms in gold, silver and shakudo inlays.

Diameter, 6 inches.

1756-JAPANESE BRONZE OKIMONO

Storks, plum tree and rocks. Signed by Anpei. Height, 61/2 inches.

1\%5\%-OLD JAPANESE BRONZE STATUETTE

Figure of pilgrim in flowing robe; finely modelled.

Height, 7 inches. 
Design of a pigeon on a tile.

Height, 7 inches.

1759-CYLINDRICAL VASE

Modern Japanese. Shibuichi, with ornamentation of panels, bam-

boo branches and crests, in various metals and enamel.

Height, 7 inches.

1760-BOTTLE-SHAPED VASE

Copper-bronze, coated with a gold aventurine patina. Old Japanese.

Height, 7 inches.

1761-OLD JAPANESE BRONZE INCENSE BURNER

Design of Hotei and his treasure bag. Fine brown patina.

1762-OLD JAPANESE BRONZE OKIMONO

Figure of a deity, surrounded by cloud forms and standing on a dragon.

1760-BRONZE WATER JAR

Height, 7 inches.

Japanese. Seventeenth century. This vessel, used for the Chanoyu, is circular in form, flat on the top and contracted toward the bottom. It has a cover and is of polychrome bronze. The vase is broad and low, of simple, exquisite form; the vertical outline, diminishing from top to base, preserves the convex curve in irreproachable proportions. The upper part is horizontally closed; the opening is square, with a very small projecting edge upon which the cover rests, this last surmounted by a small handle. The body of the vase is decorated with four large characters in low relief on a plain background, with a delicious patina throughout, in which can be seen little red clouds which emit light when in contact with the mysterious depth of the brown background.

The characters are:

$\times \times$ kats - and now, and then, notwithstanding

$X \times$ zashite - to be seated

$\times$ kissu- drink

$\times$ châ-o- tea

(Katsu zashitu châ-o-kissu)_." and to sit and drink tea."

Noтz.-Mizu-sashi is a water vase exclusively used for the Chanoyu (tea ceremony) to contain the fresh water used for replenishing the tea kettle. The water is transferred from it to the kettle with a long-handled dipper of bamboo.

"A Chanoyu (cha, tea; no, of; yu, hot water), literally 'hot water for tea,' an abbreviation of the order to prepare tea. Tea-drinking is a means to the art of self-restraint and polite customs; it refines the manners and calms 
the spirit; tea is only an accessory used as a means to bring people together. But this simple ceremony embraces all Japanese art, or at least greatly influences it. The Chanoyu takes place in a small special parlor built for the purpose. A Chanoyu party is composed of five persons, four guests and the host. The host prepares the tea and hands it to the guests. No servant interferes. The whole thing is restricted to five persons. Each person's place is prepared beforehand. The first is for the most honored guest and the fourth for the most intimate friend of the host, who assists him in different ways, principally in keeping up the conversation, while the host is pouring out and handing the tea. After the tea, which takes place in the daytime, they dine. Dinner is also served by the master of the house, who serves and eats at the same time. As regards the conversation, there is nothing set; it is an intimate sympathetic chat. At these entertainments all are equal. A penniless citizen is on an equality with the wealthiest noble. It is therefore a leveller of classes, a fusion of friendship with intellectual and philosophical life. It develops the appreciation of nature and increases the poetry of thought. This simple little ceremony is subject to many rules, which have given birth to professional teachers of Chanoyu and to schools for learning the same, such as Senke, Yabunouchi, etc. These studies include a knowledge of the works of art, architecture, gardening, the art of grouping flowers in vases, cooking, perfumes, etc., etc. Under the celebrated Shogun of the family of Ashikaga, Higashiyama Yoshima, 1449-1471, the Chanoyu became a special art. Toyotomi Hiyoshi, who died in 1598, loved the Chanoyu; he used it as a means to overcome the brutal spirit of the commanding generals, who had become so after a long civil war which lasted fifty years. It is said that he laid out his plans, political or tactical, in a Chanoyu parlor. $\mathrm{He}$ valued works of art highly and often gave his generals a piece of pottery or a bronze as a reward when they really deserved an estate. The men, after becoming chajin (amateurs of tea), experienced as much satisfaction in these acquisitions as if their property had been enlarged by the addition of half a province."

Height, 55/8 inches; diameter, 8 inches.

Exhibited at a Loan Exhibition, National Academy of Design, 1893.

1764-OLD JAPANESE BRONZE STATUETTE

A standing figure of a pilgrim in flowing robes, the base supported by symbolical bats.

Height, $71 \frac{1}{2}$ inches.

1765-BRONZE INCENSE BURNER

Shape of a rabbit. Old Japanese. Fine mottled patina.

Height, 7 inches.

\section{I766-BRONZE TRIPOD INCENSE BURNER}

Old Japanese. Globular shape, with openwork cover. Ornamented with a dragon, wave designs and Dog Foo in relief casting and partially gilded. Has bronze stand. 
1766a-OLD JAPANESE BRONZE WALL VASE

Peony and Greek fret patterns in low relief casting. Dark brown patina.

1767-JAPANESE BRONZE OKIMONO

Height, 7 inches.

A storm dragon.

1768-OLD JAPANESE BRONZE VASE

Archaic bottle-shape, with rudimentary handles; incised and relief ornaments. Rich brown patina.

Height, 7 inches.

1769-QUADRANGULAR BEAKER VASE

On dragon-head feet. Old Japanese yellow bronze. Relief and openwork ornamentation. Six-character mark of " Nakawo Munesada."

Height, 61/2 inches.

1770-OLD JAPANESE BRONZE VASE

Shaped like a classic hydria. Coated with a mottled green patina.

Height, 6 inches.

17'1-OLD JAPANESE BRONZE BELL

Inscription and crest in low relief, and a band of Greek fret in-

cised. Coated with a rich brown patina.

Height, 61/2 inches.

177\%—JAPANESE BRONZE VASE

Cylinder supported by a turtle of longevity.

Height, 61/2 inches.

$1773-H I B A C H I$

Old Japanese yellow bronze. Oval-shaped, with top handle. Orna-

mented with shell designs in relief casting and incised waves and foliated patterns.

Length, 7 inches.

1774-INCENSE BURNER

Old Japanese bronze design of a Dog Foo.

Height, 7 inches.

1775-JAPANESE BRONZE INCENSE BURNER

Design of a Dog Foo, covered with a rich brown patina. Carved teakwood stand.

Height, 7 inches.

17\%6-OLD JAPANESE BRONZE KORO

Circular shape. Supported by figures of three seated Japanese boys. Ornamented with crests and symbols in relief casting. Signed by Itcha Kanka, iru. 
By Somin. Square body with the four sides slightly convexed. Four feet; dragons gracefully curved support the vase at the four corners. Two handles, inverted U's, at the two sides. On the front and back two dragons in relief very delicately chiselled. On each side are two screens in design of rain dragons. The screens represent the four corners of the world. The background is composed of a fine chiselled design; the upper edge is encircled with a Greek fret, the symbol of clouds or sky; the lower border, waves or the ocean. As a whole the decorations represent the emblems of the world over which the dragon dominates. It carries the seal of Hoshizan Somin.

$$
\text { Height, } 6 \text { inches; } 7 \frac{3}{4} \text { inches square. }
$$

Exhibited at a Loan Exhibition, National Academy of Design, 1893.

1778-JAPANESE SILVER BRONZE STATUETTE

A finely modelled figure of a Japanese priest in flowing robes. Height, $71 / 2$ inches.

1799-BRONZE FLOWER VASE

Inverted cone shape. Ornamentation of fish finely modelled in relief casting. Base designed to represent turbulent water.

Diameter, $71 / 2$ inches.

1780-OLD JAPANESE BRONZE STATUETTE

Seated figure of Kwan-on. Copper-red patina; engraved ornamentation.

Height, $71 / 2$ inches.

1781-QUADRILATERAL BRONZE VASE

With spreading mouth. Covered with a mottled brown patina. Old Japanese.

Height, 71/2 inches.

\section{2-JAPANESE BRONZE LANTERN}

Design of hut, with thatched roof. Ornamented with gourd vine in bearing, insects and turtles modelled in high relief.

Height, $71 / 2$ inches.

1783-ANTIQUE JAPANESE BRAZIER

Low, quadrilateral shape. Fine relief ornamentation of dragon emerging from the sea, inscribed "Dai Nippon Tō-to ju Tö-un iru." (Cast by Tō-un, living at the eastern capital of Greater Japan.) 
Dog Foo, with brocade ball. Old Japanese.

Height, 8 inches.

1785-ANTIQUE JAPANESE BRONZE WINE EWER

Chinese style. Archaic bird design, finely inlaid with gold and silver, and incrusted with a verdigris-green patina. Lid surmounted by a chimera. Has carved teakwood stand.

Height, 8 inches.

1786-JAPANESE BRONZE INCENSE BURNER

Figure of Hotei, "God of Plenty," playing samisen and seated beside his treasure bag.

Length, 8 inches.

1787-HANGING VASE

Old Japanese bronze. Design of an owl on a branch.

Height, 8 inches.

1788-TWO OLD JAPANESE BRONZE KITSURI

"The God Fox" and mate, from a gateway of an old temple in Kioto.

Height, 8 inches.

1\%89-BRONZE HANGING VASE

Old Japanese. Relief bands and incised decoration. Covered with a fine patina.

Height, 8 inches.

1\%90-OLD JAPANESE TEMPLE LIBATION TESSEL

Boat-shaped, with a dragon forming handles. Curious mark underneath foot, "Kwa."

Length, $71 / 2$ inches.

1791-BRONZE HANGING FLOWER VASE

Japanese. Early eighteenth century. Has cylindrical body, decorated with a vine and fruit of the gourd in high relief. The patina is very dark brown and the metal is thin. The uneven surface of the cylinder is intentional, representing the surface of its model. This is another cire perdue, without any retouching.

Height, 81/4 inches.

Exhibited at a Loan Exhibition, National Academy of Design, 1893.

1792-JAPANESE BRONZE OKIMONO

Lotus leaf design.

Height, 41/2 inches;'length, 81/2 inches. 
1793-OLD JAPANESE BRONZE VASE

Flat oviform, on four feet. Relief ornamentation representing the long-lived couple and their deer.

Height, 81/2 inches.

1794-OLD JAPANESE BRONZE VASE

Quadrilateral shape. Bands and handles of archaic designs; figures of numerous crabs in relief at foot. Fine patina.

Height, $81 / 2$ inches.

1795-OLD JAPANESE BRONZE MIRROR

Inscriptions and symbols in relief on reverse.

1796-ANCIENT IRON VASE

Ornamented with conventionalized dragons in relief casting and partially inlaid with gold wires. Archaic and fret patterns incised and inlaid with silver wires.

Height, 81/2 inches.

1797-OLD JAPANESE BRONZE INCENSE BURNER

Design of a conventionalized horse.

Height, 81/2 inches.

1798-JAPANESE BRONZE OKIMONO

Grotesque figure of frog on a melon. Mounted on stand of basketwork design. Signed by Shōkwâ.

Height, 7 inches.

1799-OLD JAPANESE BRONZE BRAZIER

Square shape, on four feet of wave design. Ornamented with a storm dragon and turbulent water in bold relief casting. Inscribed, "Dai Nippon Tō-to ju Tō-un iru." (Cast by Tō-un, living at the eastern capital of Greater Japan.)

Height, 53/4 inches; width, 81/4 inches.

\section{0-FLOWER VASE}

Japanese bronze. End of eighteenth century. Flat body with a delicate neck, flaring broadly at the aperture, forming a double lozenge. Handles, two dragons in very strong design. The patina is a beautiful brown, shaded with red. Carved teakwood stand.

Height, 9 inches.

Exhibited at a Loan Exhibition, National Academy of Design, 1893. 
On four low supports, and with double loop handles. Ornamented with dragons and cloud forms, in relief casting and chiselled; incised Grecian pattern borders and bands. Has carved teakwood stand. By Seimin; signed, "Dai Nippon Bunsei neu Seimin iru." Dated Bunsei, $181 \%$.

Height, 9 inches.

1802-OLD JAPANESE BRONZE INCENSE BURNER

Design of Dog Foo. Inlaid with fine wires. Coated with a fine patina.

Height, 9 inches.

\section{3-BRONZE INCENSE BURNER}

Globular shape on tripod. Elaborate ornamentation of dragon and cloud forms inlaid with silver. Bold dragon handles and an openwork cover, which is surmounted by a kylin ornament.

Height, 9 inches.

1804-BRONZE INCENSE BURNER

Design of a Dog Foo. Old Japanese.

Height, 9 inches.

1805-UNIQUE JAPANESE GONG

Nineteenth century. A flat gong in beautiful black bronze decorated with birds, Hōwōs, in relief, and very fine. This is a sonorous instrument which is suspended in the Buddhist temples. The form is that of an inverted sceptre-head. In the centre of the bottom is an octagonal medallion, where the gong is struck; on the right and left of this medallion are two flying Hōwōs surrounded by clouds with well-finished detail. The two faces bear the same delicate and elegant decoration, which is in the style of the ancient Japanese Buddhist bronze. In the centre of the face is an inscription in vertical lines of handsome letters in relief giving the name of the Buddhist temple, Meianji of Kioto, and on the other side an inscription of two lines of equal beauty: one is in the centre, the other near the left edge, giving the date 1858, and the name of the priest and donator, Kiûko. Inscription, "Roku-to, Kioreizan, Meianzen ji." (The temple An-zenji in Kioto.) On reverse, "Made by Kiūrei Kenshi, chief caretaker of Füsai Ji temple, dated 5th year of Ansei period (1858), 5th month."

Height, 221/2 inches.

Exhibited at a Loan Exhibition, National Academy of Design, 1893. 
1806-BRONZE HANGING FLOWER VASE

Boat design, with figure at helm. Old Japanese.

180\%-TEMPLE VASE WITH COVER

Old Japanese bronze. Ornamented with dragons and crests in relief casting. Dragon head handles on sides.

Height, 9 inches.

1808-JAPANESE BRONZE HIBACHI

Entire outer surface covered with an elaborate ornamentation of

floral designs and inscription in relief casting. Signed underneath the foot, "Ko-ko Terunao."

Height, 8 inches; width, 8 inches.

1809-SMALL BRONZE VASE

Amphora shape. Elaborate damascened decoration of Greek fret

patterns, and a panel with birds and branches. Has loose ring handles. Teakwood stand.

Height, 9 inches.

1810-ANTIQUE JAPANESE BRONZE OKIMONO

A stork, bearing a male figure on its back. Fine workmanship. Height, $91 / 2$ inches.

1811-JAPANESE BRONZE INCENSE BURNER

Design of a Dog Foo. Coated with a fine mottled brown patina. Height, 9 inches.

1812-BOTTLE-SHAPED VASE

Japanese Gorosa bronze. Ornamented with a design representing a serpent charming an eagle, and a pine tree, in relief casting and chiselled. Rich brown patina.

Height, 91/2 inches.

1813-JAPANESE BRONZE VASE

Tall bottle-shaped. Ornamented with a band of arabesque round neck and lion-head handles. Teakwood stand.

Height, 91/2 inches.

1814-CYLINDRICAL VASE

Old Japanese bronze. Bamboo design, with shoots in relief casting. Covered with a fine mottled patina. 
1815-OLD JAPANESE BRONZE INCENSE BURNER

Shape of a Dog Foo. Coated with a brown patina.

Height, $9 \frac{1}{2}$ inches.

1816-PAIR CYLINDRICAL VASES

Japanese iron. Incised and beautifully ornamented with chrysan-

themums, butterflies and other designs, in gold, silver and other metals.

Height, $91 / 2$ inches.

1817-BRONZE BOTTLE-SHAPED VASE

Ornamented with leaf-shaped panels, and incised decoration in

Chinese style. Coated with a rich brown patina. Old Japanese.

Height, $91 / 2$ inches.

1818-BRONZE BEAKER-SHAPED VASE

Ornamented with palm-leaf patterns and an archaic band in relief casting and incised. Coated with a fine patina.

Height, $9 \frac{1}{2}$ inches.

1819-BRONZE VASE

Quadrilateral bottle-shape, with loose ring handles. Old Chinese yellow bronze, with mottled patina.

Height, 91/2 inches.

1820-BRONZE BEAKER-SHAPED TASE

Peach, pomegranate and lotus branches in relief casting. Mottled.

brown patina. Old Japanese.

Height, 101/2 inches.

1821-JAPANESE BRONZE INCENSE BURNER

Square-shaped, on four low feet. Crest and archaic designs finely

inlaid in silver. Signed by Kazu-masa. Carved teakwood stand and openwork cover.

1822-BRONZE TEMPLE GONG

Decoration of Hōwō bird and Buddhistic symbol in low relief, on a gilded surface.

1823-BRONZE INCENSE BURNER

A fabulous bird standing on a fungus. Old Japanese.

Height, 10 inches.

1824-YELLOW BRONZE INCENSE BURNER

- Design of a dog. Old Japanese.

Height, 10 inches. 
Figure of Fudo. Old Japanese.

Height, 10 inches.

1826-COPPER HIBACHI

Octagonal shape, with top handles; incised Greek fret scrolls. Fine openwork cover. Signed, "Ban-sho-hō," seisu.

182\%—LARGE BOWL ON TRIPOD

Repoussé copper. Incised and gilded ornamentation of lotus scrolls. Fine brown patina. Gilded interior. Old Japanese.

Diameter, 10 inches.

1828-ELABORATE BRONZE JAPANESE ORNAMENTAL PIECE

Design of an overflowing sake jar, supported by three figures of Japanese children. Tree peony and rocks in relief casting and two sparrows of life size on shoulder.

Height, 101/2 inches.

1829-BRONZE WALL VASE

Old Japanese. Design of a flying fish. Cast from a wax mould. Length, 10 inches.

1830-OLD JAPANESE BRONZE STATUETTE

Standing figure of a priest.

Height, 10 inches.

1831-OLD JAPANESE BRONZE INCENSE BURNER

Design of a goose. Fine dark brown patina.

Height, 11 inches.

1832-JAPANESE BRONZE INCENSE BURNER

A life-like turtle; figure of a young one forming lid. Signed by the famous Tō-un.

Length, 10 inches.

1833-BRONZE INCENSE BURNER

Elephant shape. Openwork cover. Old Japanese.

Height, 6 inches; length, 10 inches.

1834-GOROSA BRONZE BOX

Finely wrought basket design. Pomegranates and branches modelled in high relief. 
1835-BRONZE CYLINDRICAL VASE

Design to imitate an old pottery jar, with running glaze. Antique Japanese.

Height, 10 inches.

1836-OLD JAPANESE BRONZE CYLINDRICAL VASE

Ornamented with coiled dragons and cloud forms in relief casting, and coated with a fine mottled patina. Signed by "Tō-un iru."

Height, 10 inches.

1837-OLD JAPANESE BRONZE VASE

Gourd design, with tubular handles. Incised palm-leaf ornaments. Coated with a fine mottled patina.

Height, 10 inches.

1838-BRONZE INCENSE BURNER

Shape of bird. Old Japanese.

Length, 10 inches.

1839-OLD JAPANESE BRONZE VASE

Design of a Dog Foo, with open mouth.

Height, 10 inches.

1840-OLD JAPANESE BRONZE VASE

Bottle-shaped. Elephant-head handles on neck.

Height, 10 inches.

1841-JAPANESE BRONZE OKIMONO

Design of a sake imp ascending from a sake jar, and upholding a large sake saucer which forms a vase. Mounted on a stand of rock and wave design.

Height, 10 inches.

1842-MANUSCRIPT BOX

Japanese rosewood, with iron panel inserted in cover, which is ornamented with an artistically executed decoration of swimming carp.

- By Natsuwō, a great metal-worker of the nineteenth century.

Height, 31/2 inches; length, 10 inches.

1843-PAIR DAIMIO STIRRUPS

Iron, finely damascened with silver. Antique specimens.

1844-JAPANESE BRONZE OKIMONO

A large dragon skilfully modelled.

1845-JAPANESE BRONZE OKIMONO

Seated figure of "Seiwōbō" (a Chinese beauty).

Height, 11 inches. 
Eighteenth century. A representation of solitude. A fine piece of work.

Height, 10 inches.

Exhibited at a Loan Exhibition, National Academy of Design, 1893.

\section{7-JAPANESE BRONZE FLOWER VASE (HANAIKE)}

"About 1820. A large, circular cup of yellow bronze, with a foot composed of elephants. The orifice, very broad and plain, forms a horizontal ring. The bowl is in two zones, supported by a short stem. The first and largest zone is a broad band, divided into oval medallions, impressed and decorated with butterflies and bouquets in relief, upon a ground of fine design, imitating the tissue of linen. On the second zone, of half the diameter of the first, is a pendant designed of cords and tassels on a plain ground. The foot displays three united elephants, showing only their front feet; their trunks are outstretched, two upward and one downward. The united backs are draped with a housing, decorated with dragons in relief, on the centre of which is the base of the cup, an open ring, enriched with a Greek fret. The bronze is of fine texture with an olive-green patina. The composition is of fine proportions. In execution it is graceful and tasteful. It is an authentic work of the artist Seimin at Yedo. His seal is underneath the foot."

Height, $71 / 2$ inches; diameter, 10 inches.

Exhibited at a Loan Exhibition, National Academy of Design, 1893.

1848-OLD JAPANESE CYLINDRICAL VASE

Design of Makimono. Fine wicker-work pattern in various metals.

Height, 101/2 inches.

1849-BRONZE FLOWER HOLDER

Leaf design, on tripod of slender legs. Rich mottled patina. Old Japanese.

Height, 101/2 inches.

1850-OLD JAPANESE BOTTLE-SHAPED VASE

Globular body with tall tubular neck. Lion heads in relief in shoulder. Coated with a mottled brown patina.

Height, 101/2 inches.

1851-BRONZE GOURD-SHAPED VASE

Japanese. Ornamentation of foliated scrolls and symbols; cast in relief and chiselled. 
1852-BRONZE TEMPLE BELL

With clock movement inserted. Old Japanese.

Height, 101/2 inches.

1853-JAPANESE BRONZE STATUETTE

Seated figure of Kwan-on holding a lotus leaf. Finely modelled and covered with a rich brown patina. Seal mark of "Seifūsai, iru."

Height, 11 inches.

1854-JAPANESE BRONZE INCENSE BURNER

Design of a bird on lotus flower.

Height, 11 inches.

1855-ANTIQUE BRONZE OKIMONO

Chimera. Fine modelled, carved and relief ornamentation. Height, 11 inches; length, 10 inches.

1856-OLD JAPANESE BRONZE VASE

On support; of elephant design.

Height, 11 inches.

1857-HANGING TEA JAR

Old Japanese pewter. Ornamentation of lotus plants modelled in relief. Signed by Shō-zan.

Height, 11 inches.

1858-LARGE JAPANESE PEWTER TEA JAR

Oviform. Elaborate ornamentation of dragons amid cloud forms modelled in high relief and chiselled.

Height, 11 inches.

1859-BRONZE FLOWER VASE (HANAIKE)

"Japanese. Beginning of the eighteenth century. Cylindrical in form, of burnished yellow bronze, decorated with a large fish in relief, called in Japanese Shachi. The surface is polished, plain, and brilliant; the color, darkening round the lower part of the cylinder, presents the tones of dark amber. The fish, darting from the top downwards, is circumfluent. The head is hairy like the lion's, the mouth open, and the expression terrible; the body is covered with scales; the teeth and the moustache are of silver. The whole is chiselled with great strength and breadth. It is a beautiful bronze, simple and characteristic, in the style of the works of Yasuchika, one of the greatest chisellers of sword-mountings, about 1700. This object, though it does not bear the signature of 'the master,' forcibly recalls his work." Teakwood stand.

Height, 111/2 inches.

Exhibited at a Locn Exhibition, National Academy of Design, 1893. 
1860-OLD JAPANESE BRONZE OKIMONO

Life-like Tai fish. Signed on fin by Yeikō, iru.

Length, 11 inches.

1861-BRONZE INCENSE BURNER

Design of a chicken cock. Old Japanese.

Height, 11 inches.

1862-JAPANESE BEAKER-SHAPED VASE

Chrysanthemum design. Band of dragons in relief casting. Covered with a yellow patina.

Height, 11 inches.

1863-JAPANESE BRONZE VASE

Tall slender bottle-shaped; coated with a mottled red and brown patina.

Height, 11 inches.

1864-JAPANESE BRONZE JAR

Oviform. Ornamentation of wild geese, grasses and borders, modelled in relief in silver, gold and copper. Coated with a mottled patina. Signed by "Kakō."

Height, 11 inches.

1865-JAPANESE SPICE BOILER

Beautifully wrought in repoussé silver and other metals. Melon design supported by a silver branch. The handles on shoulder on pine cones of silver.

Height, 12 inches.

1866-JAPANESE BRONZE VASE

Tall slender bottle-shape. Mottled brown patina.

Height, 111/2 inches.

1867-JAPANESE BRONZE INCENSE BURNER

A life-like turtle; young one forming cover. A fine example by "Seimin," iru.

Length, 111/2 inches.

1868-BRONZE PANEL

Design of a slender-necked vase and a spray of tsubaki flower wrought in high relief; the neck of the vase is made of shakudo with gold ornamentation; the body is of porcelain and inlaid with cloisonné enamel; the tsubaki flowers are wrought in silver and gold; and the leaves are of green enamelled porcelain. Signed by Katsumi. Green lacquer frame.

Height, 121/2 inches; width, 10 inches. 
1869-BOTTLE-SHAPED VASE

Old Japanese bronze. Ornamented with bands of incised archaic designs.

Height, 11 inches.

18\%O-OLD JAPANESE BRASS WATER VESSEL

Oblong shape, with top handle. Finely engraved ornamentation of

Tycoon's crests amid leafy scrolls and gadroon borders.

1871-PAIR BRONZE OKIMONOS

Life-size chicken cocks; finely modelled. Old Japanese.

1872-SENTOKO BRONZE TRUMPET-SHAPED VASE

Lizard handles on neck. Mark underneath foot.

Height, 12 inches.

1873-JAPANESE BRONZE VASE

Bottle-shape, on a leaf design base. Panels and borders of archaic and Greek fret patterns incised. Dragon-head handles on neck. Coated with a rich brown patina.

Height, 12 inches.

1874-LARGE BRONZE VASE

Bold beaker-shape, with wide mouth. Elaborate handles at shoulder of wave design. Coated with a green patina.

Height, 12 inches.

18\%5-BRONZE TEMPLE GONG

Old Japanese. Fine tone.

Height, 71/2 inches; width, 11 inches.

1876-OLD JAPANESE BRONZE CANDLESTICK

Design of a stork and lotus.

Height, 141/2 inches.

1877-TWELVE BRONZE STATUETTES

A series of Japanese gods or deities known as the "Yakushi Jiūni Shinshō," the twelve deity generals. Bikatsu Ra-taishō, Chōto Ra-taishō, Shindatsu Ra-taishō, Mako Ra-taishō, Hai Ra-taishō, Indatsu Ra-taishō, San tei Ra-taishō, Ani Ra-taishō, Anteira taishō, Meishi Ra-taishō, Basseki Ra-taishō, Kubira taishō.

18\%8-JAPANESE BRONZE VASE

Slender bottle-shape, known as the "stork neck vase." Mottled green patina. 
Design of a gourd and vine. Coated with a fine brown patina. Old Japanese.

$$
\text { Length, } 13 \text { inches. }
$$

1880-JAPANESE IRON VASE

Bottle-shaped on tripod. Ornamentation of archaic designs inlaid in gold, copper and shakudo. Four rudimentary elephant head handles with loose rings round neck. Has teakwood stand. Height, 12 inches.

1881-ANTIQUE BRONZE OKIMONO

A storm dragon, by the great artist Tō-un. Mounted on a carved wood stand, in design of rocks, surrounded by water and incrusted with shells and ornaments of amber and other materials.

Height, 7 inches; length, 13 inches.

1882-ANTIQUE JAPANESE BRONZE FLOWER DISH

Low, circular shape on tripod; rudimentary handles with openwork cloud forms. Ornamentation of archaic designs and band of bosses carved in relief and incised. Coated with a rich brown patina. Signed Nakawo Munesada Seizō.

Height, 51/2 inches; diameter, 16 inches.

1883-JAPANESE BRONZE INCENSE BURNER

Design of recumbent cow. Finely modelled. Cover of Gorosa

bronze ornamented in relief with other metals. Signed by Jōmi of Kioto.

Length, 13 inches.

1884-BRONZE INCENSE BURNER

Peacock with spread tail. Old Japanese.

Height, 14 inches.

1885-ELABORATE JAPANESE BRONZE OKIMONO

Design of dragons amid turbulent water and rocks pursuing the Sacred Pearl.

Height, 141/2 inches.

1886-ELABORATE JAPANESE BRONZE OKIMONO

Two life-size pigeons on a tree trunk. A skilful and artistic production.

Height, 14 inches; length, 14 inches.

188\%-ANTIQUE JAPANESE BRONZE INCENSE BURNER

A crane on lotus leaf.

Height, 18 inches. 
Group of ten life-like turtles. By Seimin and signed "Seimin iru." Height, 6 inches; length, 14 inches.

\section{9-OBLONG FLOWER VASE}

Old Japanese bronze. Ornamented with dragons, cloud forms and fire emblems in relief casting. Coated with a fine brown patina.

Length, 15 inches; width, 101/4 inches.

\section{0-GOLD AND SHAKUDO STATUETTE}

Japanese. 1825. A statuette of Kwan-on, with eight arms, standing on a round throne, supported by an octagonal pedestal, made of gold and shakudo; the former represents the skin, and the shakudo is used for the hair, the crown, the costume and the pedestal.

"This small figure is one of great nobility. The goddess has half-closed, downcast eyes; the lines of the nose, pure in form, are continued in the arch of the brows, which are crescent-shaped; the mouth is small and closed, the cheeks are graceful, the chin is rounded, the forehead is low and straight, with a vertical eye in the centre. Backing this physical beauty is a still more striking moral one: the beauty of a pure soul, a noble heart, an elevated mind, and beneficent will, with an expression of deep feeling. The two first arms, raised artistically from the elbow, originally grasped a lotus branch and a staff. The two second arms are folded on the chest with joined hands, as in prayer; the two third are open to receive suffering souls, and the two fourth are lowered holding the cord which symbolizes Will, according' to the text of Senyugio: "While sowing the lotus flowers in the Ocean of life as the prey of death, with the strong cord of my will I draw therefrom, as fish, the souls of the multitude and land them on the east of Bodar' (a Buddhist world). The same spherical throne, surrounded by round and vertical reeds, represents the fruit of the lotus. The square pedestal, with truncated angles rising in contracted lines, forms a small column upon which rests the crown. The gold is covered with the smoke of incense, and the shakudo is beautiful, black, and shining with the soft lustre or shakudo is beautiful, black, and shining with the soft lustre of lacouer. This object, with every appearance of great antiquity, bears the date 1825. The following is a translation of the inscription on the back:

" 'Do not render void the vow of the silken cord.' These are the words of Kwannon's invocation. Text: Yen pu dan kin o motte corea i tatematsuro. Translation: 'This is respectfully cast in yen-pu gold.'

"The time is at the end of the station of the fixed star of the moon, the 10th month of the eighth year of Bunsu, which corresponded to the sign of the zodiac cock, combined with the principle of the female-tree. Interpreted means: "It was towards the end of October of the year 1825." "

Height, 15 inches.

Loan Exhibition, National Academy of Design, 1893. 
God of Wealth and his symbols. Finely modelled, and with engraved ornamentation; coated with a rich brown patina. Mounted on a red lacquer stand.

$$
\text { Height, 101/2 inches; length, } 19 \text { inches. }
$$

\section{2-JAPANESE BRONZE LANTERN}

Pagoda design; openwork panels. Signed underneath the foot,

"Riō-undō sei" (made at the Atelier Riō undō). Height, 15 inches.

1893-ANTIQUE JAPANESE BRONZE OKIMONO

" The Riūdsu Kwan-on." On a stand of wave design. By Momosé Jiūkiō. Signed, "Momosé Jiūkiō iru" (cast by Momosé Jiūkiō). Height, 15 inches.

1894-PAIR JAPANESE BRONZE STATUETTES

Damio ladies in full ceremonial costumes. Finely modelled, and coated with a rich brown patina. Nineteenth century.

Height, 16 inches.

\section{5-BRONZE OKIMONO}

"Carp and Seimin. Japanese. Nineteenth century. Represents an enormous carp issuing from the billows and carrying upon its head a man, standing, sword in hand. The group rests upon a platform with four feet, which is cast in one piece with the group. The carp holds its head high; the body is turned to the right and the tail waves in the air. The dashing billows, breaking in every direction, are cast in relief and are full of movement. The platform, of irregular outline, has a border decorated with a small design in relief; it is commonly known as Seizai 'Blue sea.' The feet are branches of peach tree loaded with blossoms in relief. The Seimin has a large bald head, a long beard, and strongly marked features expressive of power. The drapery of the long robe is blown by the wind. His right hand grasps his sword-handle, and the position of his feet shows he is going to have an encounter with an unseen adversary. At the same time the carp is seized with sudden fright. This bronze is replete with imagination and life. The patina is a simple dark brown. There are two Seimin which are represented with the carp, Kinko and Sheyei, but neither of these is armed with a sword. Who, therefore, is the personage represented in this group?"

Loan Exhibition, National Academy of Design, 1893.

Height, 18 inches.

Old Japanese. Finely wrought in bronze and inlaid with silver. 
Tall oviform. Ornamentation of wild geese, grasses and other designs; finely modelled in relief. Coated with a fine mottled patina. Made by Ichibei and signed, "Dai Nippon Tō-tō jū Hōgetsusai Ichibei tsukuru."

Height, 161/2 inches.

1898-JAPANESE BRONZE FLOWER VASE

" By 'To-un.' 1820-1830. The body of the vase is of a jar shape with small contracted neck, which flares to a very broad and level top. The design of the base is of rising powerful waves, from which arises the vase in form of a waterspout, in which is a dragon, his head and claws protruding in strong relief. The artist has shown great success in displaying such energetic life. It is considered one of his masterpieces. He has also endeavored to show how fine a casting can be made in cire perdue (wax casting) without after-treatment of the chisel-this casting being a direct production from the mould. The bronze in color represents iron bronze."

Height, 171/2 inches.

Exhibited at a Loan Exhibition, National Academy of Design, 1893.

1899-LARGE HANGING LANTERN

Japanese brass. Engraved ornamentation and openwork panels.

Height, 18 inches.

1900-LARGE CHINESE BRONZE VASE

Trumpet shape, with bold flange at neck. Coated with a rich patina. Antique specimen.

Height, 181/2 inches.

1901-BRONZE INCENSE BURNER

"Japanese. Early nineteenth century. This is one of Seimin's great works. It is of a most charming design. The four feet are composed of geometrical elephant heads. The detailed background is of fine diaper pattern, upon which are clouds, and in strong relief is the forepart of a dragon and on the opposite side are his projecting claws. The top curves in rapidly to a circle about $81 / 4$ inches diameter. The border of this cover is the same class of background with similar effect of dragons as above. There are two upright square handles. Around the circle is a band in design representing fire. There is also a band composing a circle of sixteen geometrical leaves. Inside this band is a dragon entwined in a sitting position. Signed and dated. Bunsei period, 1817."

Height, 13 inches; diameter, 123/4 inches.

Exhibited at a Loan Exhibition, National Academy of Design, 1893. 
1902-ANTIQUE GOURD-SHAPED JAR

Japanese repoussé copper. Ornamentation of mice, pomegranates and vines.

Height, 19 inches.

1903-PAIR LARGE JAPANESE BRONZE VASES

Beaker shape, with bold flaring mouths. Ornamented with storks, cloud forms and wave designs inlaid with fine silver wires. Butterfly handles at shoulder.

Height, 19 inches.

1904-PAIR SILVER BRONZE VASES

Japanese. Figure of warriors in relief casting and inlaid with gold and silver.

Height, 191/2 inches.

1905-PAIR JAPANESE BRONZE VASES

Tall oviform. Inlaid with enamels and gold and silver wires.

Coated with a mottled patina. Signed underneath foot, "Kakō tsukuru." With finely wrought bronze and inlaid stands.

Height, 20 inches.

1906-PAIR SILVER BRONZE VASES

Japanese. Relief and inlaid ornamentation skilfully executed.

Height, 201/2 inches.

190\%-UNIQUE CLOCK

Case of skilfully wrought Japanese bronze, in design of a temple bell, encircled by a boldly modelled dragon and incrusted with precious metals and coral. This is surmounted by a globularshaped jar of bronze inlaid with gold and enamels, and on the cover is a seated figure of a Japanese warrior, artistically wrought in bronze and exquisitely inlaid with gold, silver and shakudo. On a lacquer stand.

Height, 23 inches.

1908-LARGE ANTIQUE JAPANESE BRONZE VASE

Oviform. Wicker basket design. Unusually fine specimen of skilful modelling.

Height, 24 inches.

1909-LARGE BRONZE HANGING VASE

Tall oviform. Thread line surface, with an ornamentation imitating a running glaze at shoulder.

Height, 22 inches. 
"Modern Japanese. Shakudo bronze, gold inlaid. The incense burner is of lofty proportions. with a base in two stages supporting a square vase with round indented corners-handles formed of branches with leaves and buds-the cover in form of rock or mountain which is surmounted by a figure of the royal bird."

"The base is slightiy raised by an interior metal framework on which the piece rests. Its first stage consists of three bands narrowing in width and size upwards. The lower band has oblong horizontal panels of light-colored bronze on which are wave designs in shakudo; and coiled dragons in gold on three sides-on the fourth side an inscription on irregular gold panel, with a wave design indented border. Between these panels on the rounding corners are hexagons in shakudo containing coiled dragons in gold button-shaped knots. This hexagon ornament is conceived as bordering the panels above and below -where the width only allows to appear a zigzag band of shakudo with rows of the button edges cut by brass rims. The second band of the first stage has relief waves in shakudo inlaid with spots of gold. The third band has small oblong panels with bronze or gold animals in relief on a diapered ground of diamond pattern (gold dragons in shakudo border). At the upper corners of the first stage are openwork railings with gold inlaid Dog Foo. Above this stage rises another in narrower bands, two of them narrowing to a concave moulding, on which are gold dragons in high relief and small panel with inscription. Above this, five more bands widening to another platform (with railed openwork corners, gold inlaid flowers) on which the vase proper rests (all bands with gold inlaid diapers or design). The body of the vase has a relief panel on each side; one relief, with gold, silver and bronze inlay, represents two human figures in guise of butterflies. On the reverse panel a landscape. The leaves of the handles are veined with gold and the buds are gold. Under the flaring edge of the vase relief, storks on cloud relief ground, beside one of the storks an inscription on curved gold panel. On the cover the rock has gold splashes. The bird is of gilt bronze with gold inlaid shakudo wings and tail feathers. The inside of the cover has a flat burnished shakudo surface, with royal bird cut in openwork."

An exhibition specimen of Japanese art in metals. The storks under the lip of the koro are by Nobu-Masa; the panels by RitsuMin; the cherry branches, forming handles, by Masa-toshi when 22 years old, and the base and main bronze work by Suzuki Gensuké of Tokio.

Height, 34 inches; width, 16 inches.

1911-ELABORATE BRONZE STAND

Design of turbulent water. Old Japanese.

Length, 23 inches.

1912-PAIR TALL CANDLESTICKS

Japanese bronze. Stork design. 
Globular shape, of corrugated surface, on tripod support of openwork floral scrolls, which are inlaid with fine silver wires. Handles of conventionalized dragon design also, inlaid with silver. The cover surmounted by a fabulous animal. Golden yellow patina.

Height, 25 inches; diameter, 14 inches.

\section{4-LARGE JAPANESE BRONZE VASE}

'Tall oviform. Ornamented with archaic designs in relief and incised; ring handles at shoulder. Coated with a rich patina.

Height, 21 inches.

1915-ANTIQUE JAPANESE BRONZE WATER URN

Globular shape, with handles and spout of floral design; band of bold sceptre heads round shoulder and upright palmettes encircling the foot. Cover surmounted by figure of a kylin.

Height, 27 inches; diameter, 17 inches.

1916-PAIR LARGE KYLINS

Old Japanese bronze. Of skilful workmanship; coated with a rich brown patina.

Height, 26 inches; length, 27 inches.

1917-PAIR JAPANESE BRONZE CANDLESTICKS

The long-legged and long-armed man.

Height, 30 inches.

1918-TWO ELABORATE JAPANESE BRONZES

Dolphins resting on their breasts, with open jaws and their tails erect. Of fine workmanship.

From the Bing Collection, Paris, 1885.

Height $321 / 2$ inches.

\section{9-GRAND INCENSE BURNER}

Antique Japanese bronze. Square shape on tall supports and of graceful design. In three panels are an ornamentation of branches of blooming peonies worked in high relief, and on a fourth panel an inscription (undecipherable), probably referring to the dedication of the piece to some temple and the name of donor. The cover is of openwork cloud forms and is surmounted by a boldly modelled figure of a kylin. The base is ornamented with an engraved dragon and an ornament representing the Pearl of Omnipotence. 
1920-LIFE-SIZE CRANE

Japanese bronze, of fine workmanship.

1921-JAPANESE BRONZE LANTERN

A dragon, bat symbols and other designs in bold relief.

Height, 34 inches.

1922-ANTIQUE JAPANESE BRONZE FOUNTAIN

Lotus design. Coated with a fine mottled green patina.

Height, 32 inches; width, 42 inches.

1923-ANTIQUE JAPANESE BRONZE FOUNTAIN

Lotus design. Companion to the preceding.

Height, 32 inches; width, 42 inches.

1924-ELABORATE BRONZE KORO

Boldly modelled dragon and figure of a Sennin (a fabulous personage), illustrating a Japanese legendary subject: "Susaro Mikoto recovering his lost sword blade from a dragon by giving it sake to produce intoxication." The bronze has a black patina. There is movement and character in this group which render it quite original. Japanese, 1800-1830. With red-lacquered stand. Height, 21 inches; length, 40 inches.

1925-OLD JAPANESE BRONZE JARDINİERE

Oblong shape, on four grotesque heads; dragon head handles. Ornamented with incised wave patterns.

Length, 321/2 inches; width, 201/4 inches.

1926-JAPANESE BRONZE OKIMONO

Life-size eagle perched on a rock.

Height, 38 inches.

1927-PAIR ELABORATE JAPANESE BRONZE VASES

Made in sections. Tall, oviform body on a group of stands and with bold flaring mouths. Profusely ornamented with Japanese historical subjects, flowers, fruits, fish and other designs, most skilfully wrought in high relief and in openwork. Golden brown patina. 
"Japanese. 1832. A tripod of the form known as Shaku (sacred vessel), with one handle. A very large oval body without a base, the sceptre broad and spreading out on the two sides, one of which is almost pointed, the other being a broad mouth from which flows the surplus water. On one side is a vertical handle formed by a rhinoceros' head with outdrawn tongue. On the edge rise two vertical columns encircled by dragons. On the body on either side of the large handle are two very important panels decorated in relief with elephants magnificently housed. The feet are decorated with two dragons framed in by a narrow Greek border. The bronze has a black patina, and beyond the decoration mentioned is perfectly plain and smooth. The form is designed with unusual correctness, as shakus usually are not thus proportioned. A shaku of this size would usually be thin and shapeless. The artist in this instance has made a large, solid and graceful object. The decorations are well in their places and add to the beauty of the plain parts. The outline is pure, the style grand and noble, and the execution simple and firm."

Above the handle the following inscription is cast:

"Cast by Seimin, aged 73, the 10th month of the 3d year of the temple of Japan" (1832).

"This inscription is very important as giving positive proof concerning the master. We can learn from it the date of his birth, and the old age he attained; that is to say, that 'Seimin, the great Japanese bronzist, was born at Yedo in 1760 , and continued to produce remarkable work as late as 1832.'

" The importance of this bronze is not confined to its beauty; to the Japanese artistic world, it is a monument to the ability of this master. I do not know what important specimen of Seimin's work may remain in Japan, but to the Japonists of Europe and America this is the sole and unique monument of his art. I acknowledge being struck when I first beheld this piece in Paris, and to-day, after examining it more carefully, I find it still more beautiful. It was while translating the inscription on it, that I secured the exact dates concerning Seimin that I had been heretofore unable to furnish to European amateurs. The small hole in the bottom was intended for the introduction of the pipes supplying the water, 'Hayashi." "

Height, 33 inches; diameter, 39 inches.

Loan Exhibition, National Academy of Design, 1893.

\section{9-OLD JAPANESE BRONZE FOUNTAIN}

Low circular shape on tripod support. Ornamentation of dragons applied in bold relief. Handles formed by boldly modelled dragons. 
"Period: beginning of the nineteenth century. An elephant reposing, carrying an incense burner on its back. It is therefore composed of three pieces: the elephant, the incense burner, and the cover. The animal, with his front legs folded under him, lies close to the ground, turning its head to the left side, which is the front of the object, and raises his trunk between the two tusks, while the left ear falls heavily. A magnificent double carpet covers the back and receives the incense burner. The design of the carpet, which is simulated rings of phonixes and dragons on a ground of hexagonals, is chiselled with very strong strokes, which, nevertheless, convey an idea of minuteness when compared with the enormous size of the animal. The body of the incense burner, which is round and bulging, is surrounded at the bottom by an immense double lotus in high relief. The upper part is circled by four panels, two large and two smaller; the large ones bear inscriptions in large and straight letters, while the smaller panels are chiselled with small inscriptions. The cover, in the form of an arch, is encircled by twelve medallions representing the twelve animals of the zodiac, in highly accentuated relief; and the apex is crowned with an immense pearl issuing from the waves, which dash up on its four sides." The following is a translation of the four panels:

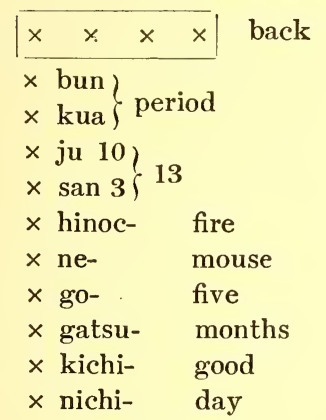

Which reads

A good day of the 5th month of the 13th year of Bunkiva, corresponding to the sign of the zodiac mouse going with the element of fire.

$$
\begin{aligned}
& \left.\begin{array}{l}
\square \text { kon } \\
\square \text { pi } \\
\square \text { ra }
\end{array}\right\} \text { Konpira } \\
& \left.\begin{array}{l}
\square \text { dai } \\
\square \text { gon } \\
\square \text { gen }
\end{array}\right\} \text { Daigongen }
\end{aligned}
$$

This is the name of the god to whom the incense burner was offered.

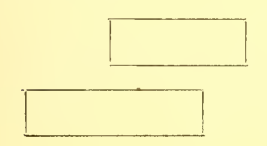

These two small chiselled panels bear the names of the eight citizens who presented this object to the temple, and the name of the temple Kon Pira Dai Gon Gen.

Red lacquered stand. Height, 32 inches; length, 28 inches. Exhibited at a Loan Exhibition, National Academy, 1893. 
"Japanese. Nineteenth century. Of immense size, spherical in form with three feet and two handles formed of Corean lions and a cover which is a piece taken from the upper part of the sphere, crowned with a large lioness and two cubs, one of which is on her back. "This is a beautiful bronze of large dimensions, solid form, pleasing decoration, lifelike accessories, clean and sharp in casting, with rich patina, and minute workmanship of magnificent effect. The sphere is horizontally divided into several bands, five of which are more important than the others. The principal and central band is decorated with twelve small, round medallions placed at equal distances on a background of fine regular fret. These medallions represent the phœnix ho-ô, the kirin, the turtle and the dragon, in delicate low relief. The band above this is decorated at the top and bottom with a series of medallions each bearing in its centre small dragons and clouds; on this band are fastened the two small lions that constitute the handles; above this is the line of opening upon which the cover rests, continuing the outline of the sphere. Below the middle band is a narrow intermediate compartment; this is decorated with the flower Kikio in low relief. The next band is broad and decorated top and bottom with a regular lambrequin design. Beneath this is a large section occupying all the lower part of the sphere, which is decorated with various designs in low relief. The three lions which support the sphere are large and give the entire figure. These three animals by their size add much breadth to the bronze. The upper part of the cover is decorated with a scroll of peonies on a regular background. The dividing line between the cover and the body is concealed by several concentric lines displaying a motive chiefly of snow and flowers. The lioness occupying the place of honor as a knob, is as large as the lions at the base; she stands on her four legs with one cub near her and another on her back, which adds materially to the composition of the subject.

"Inside the cover is a phœnix ho-ô and small cloud dragons in a low relief as carefully executed as those on the outside."

On the bottom is the distinct rectangular mark of Suzuki Masayoshi, an artist of Tokio.

Height, 3 feet 3 inches.

Loan Exhibition, National Academy of Design, 1893. 
"Japanese. 184\%. The body is of the form of a flat bulb, with a straight, low neck; on either side of the neck are fitted two upright handles. A semi-spherical cover pierced with a design, in relief, of peonies of almost natural life-size is surrounded by a lion with his front paws resting on the ground, and his body, hind legs, and tail raised vertically in the air. He raises his head slightly, with open jaws and angry glances. When viewed from the profile the lion's expression is very lifelike. The body of the incense burner is decorated with a row of six medallions placed at the shoulder below the neck; each medallion bears a peony blossom in relief, and the outline is defined by a broad prominent line broken into six lobes. The rest of the object is plain, with the exception of the base or stand, which represents the peak of a rock with flowers. It is of Karacane bronze with very dark brown patina. Its bold treatment is accounted for by its being destined for a place in one of the large temples. This bronze having been made for daily use in the temple looks much older than it really is. It is dated 184\%. It bears, moreover, a long inscription engraved on the back, which says that it was subscribed for and presented by eleven persons in the time of An-yo-ji of the province of Hôki, in the year 184\%. The artists who made it were Saji Terusada and Mabuchi Hide-tsuna. The inscription reads as follows: 'Respectfully presented before the God of the Buddhist temple An-yo-ji in the Saikon temple also called Yemisan (Mountain of Yemi), in the district of Yami, in the province of Hôki.' The temple An-yo-ji is one of the places where service is held by Imperial order in the country of Great Japan. The time is the 19th day of the 1st month of the 4th year of (the period) Kokwa, year corresponding to the sign of the zodiac 'serpent' (19th of January, 184\%)." With carved oak pedestal.

Height, 53 inches.

Loan Exhibition, National Academy of Design, 1893. 
"Japanese. 1716. Large statue of Buddha sitting on a round seat simuiating a lotus, placed on a high pedestal, in form an inverted leaf of the same plant, of beautiful dark brown bronze."

"The chest and right arm of the Buddha are bare, the legs are crossed in the way of Zazen, the two hands are joined on the lap, and the head bare with the hair curled tight. The physiognomy fully expresses the calm of Nirvana, attributed to Buddha. This expression is rendered more noble by the pose of the figure and the simple and elegant drapery, which is sharply and gracefully cut. The seat simulating a lotus flower has petals in relief, all the lines being indented. The pedestal, a lotus leaf, rests on a thin, round base. The veinings of the leaf are cut in relief. Around the seat and on the lotus petals are cut twenty honorary names of deceased persons. On the inverted leaf is engraved a long inscription, giving the date, 1716, the names of the givers, and of the bronzist: Yamamoto Mimbu."

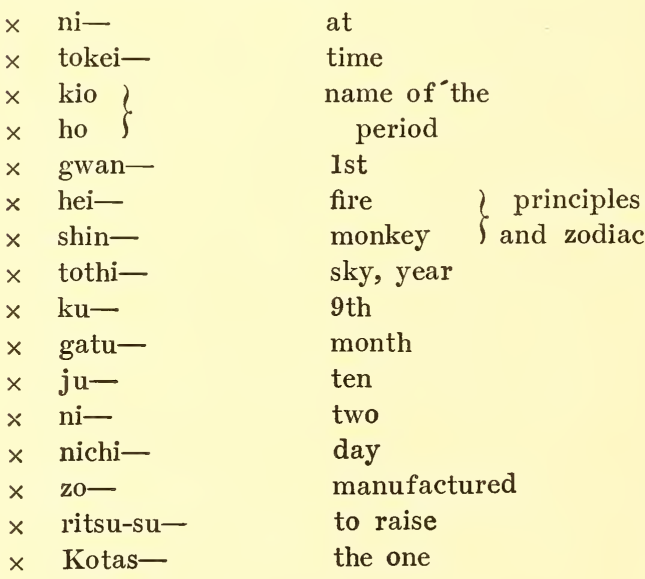

Iokini

Kioko

Gwan

Heishin

no-Toshi

Kugatsu

Juninichi

Korea

Zoretsusu

At the time of the 12th day of the 9th month of the first sky of Kioho (1716) it is (the statue) erected.

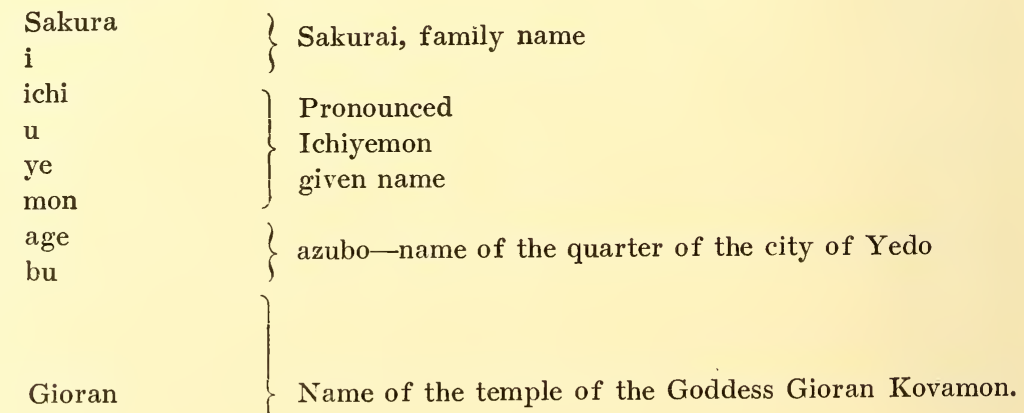


Nagamatsu, street at the foot of Gioran temple at Azabu. (This address refers to the two following.)

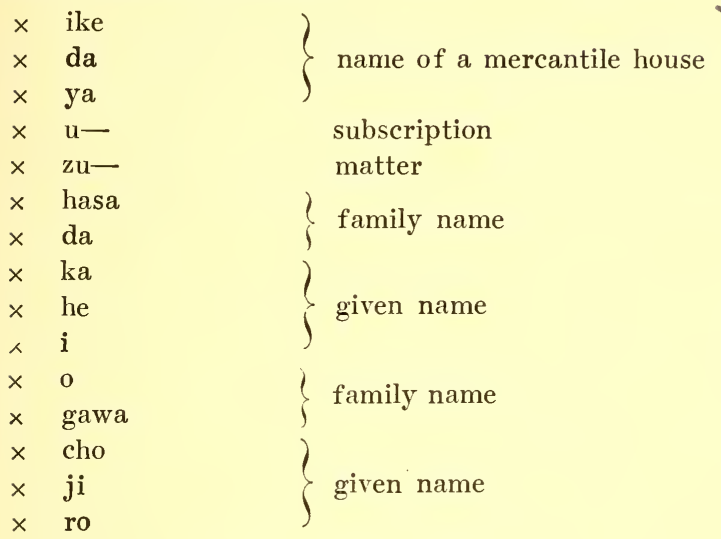

Here is a transcription of the above:

"Sakuri Tehiyemon, and Harada Kabei, and Ogawa Chojiro, the two managers and organizers of the subscription made in the house of Ikeda in Nagamatsu Street, at the foot of Gioran at Ayabu (temple)."

The above goes to prove that the statue was in a temple of Yedo.

Then:

\begin{tabular}{|c|c|}
\hline $\begin{array}{l}\text { is } \\
\text { mono }\end{array}$ & Bronzist or master founder \\
\hline shi & \\
\hline $\begin{array}{l}\text { yama } \\
\text { moto }\end{array}$ & family name \\
\hline $\begin{array}{l}\min \\
b u\end{array}$ & given name or honorary title \\
\hline
\end{tabular}

"Yamamoto Mimbu, master bronzist."

On an elaborate Japanese carved wood pedestal.

Loan Exhibition, National Academy of Design, 1893.

"Illustrating a mythological subject. A skilfully modelled dragon clutching the Pearl of Omnipotence--a vapor issuing from its mouth forming a koro-the cover of which is surmounted by an eagle supporting a statuette of a deity. The dragon and eagle are mythological representations of power and strength. The figure on the back of the eagle is a goddess of music, with a musical instrument called 'kobo,' one of the oldest known in Japan."

Height, 5 feet 5 inches.

1935-MONSTROUS ARTICULATED WROUGHT-IRON DRAGON

The jaws, tongue, legs, claws and scales are movable. A remarkable specimen of skilful workmanship by the Japanese artist ShigéYoshi. Signed, Takaishi Shigé-Yoshi. 



\title{
EIGHTH AFTERNOON'S SALE
}

\author{
THURSDAY，JANUARY 25 1906
}

\section{AT THE AMERICAN ART GALLERIES}

BEGINNING AT 2.30 o'CLOCK

\section{REMARKABLE SPECIMENS OF ARTICULATED WROUGHT IRON WORK}

\section{6-ROUND IRON BOX}

Japanese. Nineteenth century. Repoussé ornamentation, representing a dragon and waves, relieved by treatment of inlaid gold. Silver lining. Signed, Tadatoshi Chōsaburo.

Height, 3 inches; diameter, 5 inches.

Loan Exhibition, National Academy of Design, 1893.

\section{7-REPOUSSÉ IRON TOBACCO BOX}

Figure with temple bell ornamenting lid. Old Japanese. Signed, Tosa Hidéfusa.

1938-OLD JAPANESE IRON INCENSE BOX

Design of a quail. Fine workmanship.

1939-IRON PERFUME BURNER

Elaborate ornamentation of landscapes, crests and other designs in gold damascene. Signed by Miyabé Tsukuru, a Kioto metalworker. Has teakwood stand.

Height, 31/2 inches.

1940-ARTICULATED IRON CRAYFISII

Fine example of Muneyoshi. Signed Miōchin Muneyoshi, at the age of 73 years. 
1941-ARTICULATED WROUGHT IRON FROG

Japanese. Seventeenth century. All the regular joints, also mouth, eyes, and toes, are movable.

Loan Exhibition, National Acadeny of Design, 1893.

Length, 33/4 inches.

1942-LIFE-SIZE SNAKE

Old Japanese. Articulated wrought iron.

1943-ARTICULATED WROUGHT IRON INSECT

Japanese. Nineteenth century. A "Praying Mantis." The head and all the legs are movable. Wings can be removed showing an opening in the body which is a little secret box.

Loan Exhibition, National Academy of Design, 1893.

Length, 6 inches.

1944-ARTICULATED WROUGHT IRON DRAGON FLY

Fine old Japanese workmanship.

1945-ARTICULATED WROUGHT IRON INSECT

A "Praying Mantis." Old Japanese specimen.

1946-ARTICULATED WROUGHT IRON CRAB

Japanese. Nineteenth century. Designed to use as a box. Signed, Miōchin.

Width, $61 / 2$ inches; length, $3 \frac{1}{4}$ inches.

Loan Exhibition, National Academy of Design, 1893.

1947-ARTICULATED WROUGHT IRON SHRIMP

Fine old Japanese specimen. Made by Kozayemon Yoshihisa. 1630-16\%0.

1948-LIFE-SIZE KOI FISH

Japanese. Articulated wrought iron. Skilfully executed speci-

men. By Miōchin Yoshimichi. 1521-152\%.

1949-BRONZE CARP

Japanese. Eighteenth century. This carp is supposed to be located at the foot of a waterfall, in the act of commencing to scale it. An artistic production. 
A very short body with scales, a fan tail, and dragon's head; the stomach similar to that of a beetle: the wings like those of a grampus. Old Japanese.

Loan Exhibition, National Academy of Design, 1893.

Length, $91 / 2$ inches.

1951-WROUGHT IRON ARTICULATED CARP

"Old Japanese. Articulated in cross-sections and fins. Its peculiarity is its representation of material, resembling the natural skin of the carp of that country to the extent that one might doubt its being of iron. It is the only article in iron that the late owner of this collection has ever seen of this peculiar representation of material. By its construction it is evident that it was made by a different artist than any of those represented in this collection."

Loan Exhibition, National Academy of Design, 1893.

Length, $11 \frac{1}{2}$ inches.

1952-WROUGHT IRON CROW

Japanese. Seventeenth century. Life size; attitude and expression of life wonderful. It is an unusually fine specimen of ancient ironwork by the great artist, "Miōchin Munefusa."

Loan Exhibition, National Academy of Design, 1893.

Length, 15 inches.

1953-WROUGHT IRON ARTICULATED PEACOCK

A fine specimen by Miōchin.

Loan Exhibition, National Academy of Design, 1893.

Length, 14 inches.

1954-ARTICULATED WROUGHT IRON FLYING DRAGON

Japanese. Seventeenth century. Skilfully wrought specimen by Miōchin.

Loan Exhibition, National Academy of Design, 1893.

Length, 16 inches.

1955-ARTICULATED WROUGHT IRON DRAGON

Japanese. Nineteenth century. The jaws, tongue, legs, claws and scales are movable. The workmanship is of unusual quality. Signed, "Munenobu, tsukuru."

Loan Exhibition, National Academy of Design, 1893.

Length, 24 inches.

1956-SPECIMEN OF ARTICULATED WROUGHT IRON

Large fiying fish. Old Japanese specimen. Has teakwood stand.

Length, 20 inches. 
195'y-WROUGHT IRON ARTICULATED FISH-THE GRAMPUS

This fish has four articulated feelers, $71 / 2$ inches long, movable scales which are diamond-shaped. An unusually important piece.

Loan Exhibition, National Academy of Design, 1893.

Length, 241/2 inches.

1958-WROUGHT IRON HERON

Japanese. Seventeenth century. In the attitude of walking.

Many of the feathers are of separate pieces. Attributed to Miōchin.

Loan Exhibition, National Academy of Design, 1893.

Length, 17 inches.

1959-ANTIQUE IRON BOX

Design of two carps in repoussé. Old Japanese.

Length, 15 inches.

1960-LARGE JAPANESE IRON PLAQUE

Artistically ornamented with mythological subjects, various symbols and diaper patterns in gold and silver damascene.

Diameter, 15 inches.

1961-TWO HINDOO IDOLS

Wrought in bronze, and gilded and cnamelled.

1962-OLD THIBETAN IDOL

The thousand arm "God of Conception." Wrought in bronze.

19C3-OLD HINDOO IDOL

Figure of a male Hindoo deity seated on a lotus. Wrought in

bronze, and gilded and incrusted with coral and turquoise.

Height, $\tau$ inches.

\section{ANTIQUE CHINESE BRONZES}

1964-SET OF CHINESE SEAL MARKS

Nest of five. Wrought in bronze.

1965-MINIATURE INCENSE BURNER

Old Chinese yellow bronze. Incised and openwork decoration.

Signed, "Ta Ming Wan-li nien chih."

1966-SNALL OKLMONO

Thibetan. Equestrian figure, a priest and attendant, in yellow bronze. 
1967-SACRIFICIAL CUP

Old Chinese. Gilded bronze. Lotus flower design.

1968-PAIR SMALL INCENSE BURNERS

Double bird-shaped. Old Chinese bronze, inlaid with gold and silver. Teakwood stands.

1969-SMALL VASE

Double bird-shaped. Old Chinese bronze, finely inlaid with gold and silver. Teakwood stand.

1970-SACRIFICIAL CUP

Old Chinese bronze. Mottled red and brown patina; archaic border. Signed by seal (indistinct). Teakwood stand.

1971-WATER KETTLE

Old Chinese yellow bronze. Foliated and leaf designs in relief casting. Seal mark of Seiriū, tsukuru.

1972-SMALL INCENSE BURNER

Double bird-shaped. Old Chinese bronze, inlaid with gold and silver.

1973-SQUARE INCENSE BURNER

Old Chinese bronze. Ornamented with "the eight trigrams" and a storm dragon in relief casting and enamelled panels. Elephant head handles.

Height, $3 \frac{1}{2}$ inches.

1974-SMALL BRONZE INCENSE BURNER

Old Chinese. Cone-shaped; hammered and repoussé ornamentation. Rich brown patina. Teakwood stand.

Height, 4 inches.

1975-OLD CHINESE BRONZE INCENSE BURNER

Low, circular shape with rudimentary handles. Decoration of peony scrolls inlaid with fine silver wires. Six-character mark of Ta Ming Hsüan-te nien chih. Teakwood stand and cover.

Height, 4 inches.

1976-BRONZE INCENSE BURNER

Old Chinesê. Relief ornamentation and openwork cover; partially gilded. 
Bird-shaped, with archaic designs in relief casting.

Height, 5 inches.

1978-BRONZE INCENSE BURNER

Old Chinese. Inverted bell shape with rudimentary handles, on tripod support of elephant heads. Coated with a rich mottled brown patina. Six-character mark, "Ta Ming Hsüan-te nien chih."

Height, 41/2 inches.

1979-OLD CHINESE BRONZE INCENSE BURNER

Jar shape, supported by figures of three Chinese boys. Mottled brown patina. Mark underneath foot, Ta Ming. Carved teakwood cover.

Height, $4 \frac{1}{2}$ inches.

1980-OLD CHINESE BRONZE BRAZIER

Globular shape on tripod. Openwork cover in design of cherry blossoms. Mottled patina. Six-character mark of $\mathrm{Ta}$ Ming Hsüan-te nien chih. Carved teakwood stand.

Diameter, $4 \frac{1}{2}$ inches.

1981-SMALL TEMPLE WINE VESSEL

Old Chinese. Bird-shaped bronze which is finely inlaid with gold and silver and coated with a malachite and mottled red incrustation. Teakwood stand.

Height, 5 inches.

1982-BRONZE INCENSE BURNER

"Hsüan-te. 1426-1435. A cup with cover; the form and decoration represent the fruit of the lotus wrapped in a leaf and tied with a cord. Two heads of the bird Hōwō (Phœnix) maintain the cord and constitute the handles. The cover is openwork, displaying two dragons with a chain of clouds at the edge; and is surmounted by a cylindrical knob representing a section of the stem of the lotus. The patina is olive-green. The lower part of the centre panel bears the date of Hsüan-te with the usual inscription."

Loan Exhibition, National Academy of Design, 1893.

Height, $4 \% \frac{3}{4}$ inches.

1983-OLD CHINESE WINE EWER

Brass, gilded; relief ornamentation of plum blossoms, flowers and birds in panels. 
1984-BRONZE TWIN VASES

Old Chinese. Double cylinder shape, with birds and grotesque dragons in high relief. Coated with a malachite green incrustation.

Height, 5 inches.

1985-BOTTLE-SHAPED VASE

Old Chinese yellow bronze. Ornamented with incised archaic designs.

Height, 5 inches.

1986-OLD CHINESE BRONZE INCENSE BURNER

Relief and etched ornamentation. Gilded openwork cover surmounted by a kylin. Carved teakwood stand.

Height, 8 inches.

198\%-BRONZE FLOWER VASE

"Wan-li, 15\%3-1619. Of red bronze, inlaid with silver; in form a flaring square cornet with a broad and well rounded girdle which constituted the body; the four angles are indented. The inlaid design on each face of the neck represents a beetle; lozanginal medallions with sea dragons on the body; and a series of small panels on the base. Incised character mark underneath the foot, Hsüan-te."

Height, 43/8 inches; 4 inches square.

Loan Exhibition, National Academy of Design, 1893.

1988-SMALL BRONZE VASE

Tall hexagonal shape. Old Chinese yellow bronze. Has loose ring handles.

Height, 51/2 inches.

1989-TRIPOD INCENSE BURNER

Old Chinese. Lotus design body; band of dragon and cloud forms in relief casting and chiselled; openwork cover of similar design and surmounted by a phœnix. Date marks of Ta Ming Hsüan-te nien chih. Finely carved teakwood stand of lotus leaf design.

Height, 51/2 inches.

1990-TRIPOD INCENSE BURNER

Old Chinese bronze. Globular shape on three tall, slender legs. Ornamented with archaic designs finely inlaid with silver. Openwork teakwood cover with carnelian ornament. 
Elephants supporting small vase, which is partially gilded; the vase covered with a verdigris green patina. Teakwood stand.

IIeight, 6 inches.

1992-TRIPOD INCENSE BURNER

Old Chinese bronze. Ornamented with archaic designs of Haouteen faces in low relief and inlaid with gold and silver. Carved teakwood stand and cover, the latter surmounted by a white jade ornament.

Height, 6 inches.

1993-CYLINDRICAL VASE

Old Chinese bronze. Openwork design of dragons amid cloud forms and fire emblem, chasing the Pearl of Omnipotence.

Height, 6 inches.

1994-TRIPOD INCENSE BURNER

Old Chinese. Band of archaic designs in relief casting. Teakwood stand and cover, the latter with jade ornament.

Height, 6 inches.

1995-BEAKER-SHAPED VASE

Old Chinese. Ornamented with bronze archaic designs and Haouteen faces, which are incised and inlaid with gold and silver wires.

Height, 6 inches.

1996-TRIPOD INCENSE BURNER

Old Chinese bronze, inlaid with silver wires; design of Haou-teen faces. Carved ròsewood cover with jade ornament. Six-character mark underneath foot signifying "everlasting treasure."

Height, 6 inches.

1997-OLD CHINESE BRONZE INCENSE BURNER

In design of a fabulous animal; inlaid with silver and gold. Coated with a fine mottled patina.

Height, 6 inches.

1998-OLD CHINESE BRONZE INCENSE BURNER

Low globular shape. Elaborate ornamentation of lotus scrolls and various borders in relief casting and incised. Openwork cover. Six-character mark, "Ta Ming Hsüan-te." 
1999-CHINESE SENTOKO BRONZE INCENSE BURNER

Gold aventurine patina. Seal mark of Hsüan-te period. On a stand of the same bronze.

Diameter, 61/2 inches.

2000-TEMPLE ALTAR WINE VESSEL

Old Chinese. Bird shape, inlaid with archaic scrolls in silver and gold. Coated with a fine mottled red and green patina.

Height, $6 \frac{1}{2}$ inches.

2001-OLD CHINESE BRONZE VASE

Design of bird on wheels supporting a beaker-shaped vase. Coated with a verdigris-green patina.

Height, 61/2 inches.

2002-BRONZE INCENSE BURNER

Supported by tripod of elephant heads. Six-character mark of

"Ta Ming Hsüan-te." Carved teakwood cover.

Height, 61/2 inches.

\section{3-BRONZE INCENSE BURNER}

Low, circular shape on a tripod of grotesque heads; relief and incised ornamentation. Old Chinese. Teakwood stand.

Height, 6 inches; width, 111/2 inches.

\section{4-BRONZE INCENSE BURNER}

"About the end of eighteenth century. Represents the head of a dead person; the head is open above the bandeau and was closed by the cover, which formed the scalp (this cover is lost). The head is admirably modelled; the features are contracted, and through the skin can be seen all its anatomical formation. The eyes are closed; a slight frown is on the brow; the closed mouth reveals the upper teeth buried in the lower lip; the hair is gathered and tied at the back of the head, but a few thick locks fall on each side of the face. The mysterious patina intensifies the sinister impression made by this sad monument. This head, which thrills us at first sight, is not the mere fancy of an artist; it illustrates an event in the history of Japan, in which a Japanese ambassador was burned alive by the Chinese, who afterwards used his skull as a lamp. They surnamed this unhappy prisoner 'Todai-Ki' (The Devil's Lamp)."

$$
\text { Height, } 7 \% / 8 \text { inches; width, } 65 / 8 \text { inches. }
$$

Loan Exhibition, National Academy of Design, 1893. 
Semi-globular shape. Dragons amid cloud forms in relief casting.

Six-character mark underneath foot, "Ta Ming Hsüan-te."

Diameter, 7 inches.

\section{6-LARGE BRONZE JAR}

Semi-globular shape with lid and ring handles. Haou-teen faces and archaic designs in bold relief casting. Covered with a rich brown patina.

Height, 7 inches.

\section{0\%-SUPERB ANTIQUE CHINESE JEWEL CASKET}

Oval shape on four feet. Gilded copper, beautifully and profusely ornamented with incrusted coral and enamels. Underneath foot and inner surface of cover decorated with etched scrolls.

Height, 7 inches; length, 10 inches.

\section{8-ANTIQUE CHINESE BRONZE VASE}

Oviform bottle shape. Dragon head and loose ring handles; ornamented with bands of archaic designs and palmation in relief casting and incised. Round neck are the eight trigrams. Covered with a fine mottled patina. Inscription underneath foot. "Lasting Treasure." Teakwood lacquer stand.

Height, 71/4 inches.

2009-CHINESE BRONZE VASE

Interesting bottle shape, with bold flange at mouth. Archaic designs and palmations in panels in relief casting. Coated with a mottled green and brown patina. Teakwood stand.

Height, 71/4 inches.

\section{0-OLD CHINESE BRONZE KORO}

Supported by a tripod of elephant heads. The cover is surmounted by a kylin. Yellow patina. Six-character mark of " $\mathrm{Ta}$ Ming Hsüan-te nien chih.".

Height, 71/2 inches.

\section{1-OLD CHINESE BRONZE STATUETTE}

Seated figure of Kwan-on. Finely modelled. Has stand to correspond. 
2012-OLD CHINESE BRONZE OKIMONO

Equestrian and other figures. Mountain scenery and temples.

Height, 71/2 inches.

2013-TWIN VASES

Antique Chinese bronze of dense texture. Design of two cylinders supported by dragons. The symbolical bat, shou mark, various symbols and cloud forms in relief casting; coated with a fine mottled red and brown patina. Bronze stand to conform. Sixcharacter mark of Ta Ming Hsüan-te nien chih underneath the foot.

Height, 71/2 inches; width, 91/2 inches.

2014-ANCIENT CHINESE BRONZE OVIFORM JAR

Ornamented with bosses and incised diaper patterns. Coated with a fine mottled green and brown patina.

Height, 8 inches.

2015-BRONZE BELL

Relief ornaments of the eight trigrams. Old Chinese.

Height, 8 inches.

2016-BRONZE WATER KETTLE

Old Chinese. Phœnix and kylin, pine tree and other designs in relief casting.

$51 / 2$ inches by 8 inches.

2017-ANTIQUE CHINESE BRONZE VASE

Flat oviform. Decoration of Haou-teen faces and archaic designs, modelled in low relief and chiselled. Coated with an interesting patina of mottled red and brown. Ming period. Carved teakwood stand.

Height, 8 inches.

2018-TEMPLE WINE VESSEL

Old Chinese bronze. Globular shape, on feet; ornamented with a wide band of archaic designs and a narrow band of rudimentary scrolls modelled in relief and inlaid with fine silver wires. Two dragon handles. The cover ornamented to conform and inscribed on the inner surface " the lasting treasure." Coated with a mottled red incrustation. Ming period. Finely carved teakwood stand. 
"Tripod of yellow bronze with gold spots, low and round in form with a very short neck curving inward to flare elegantly at the orifice. Three small feet simulating the quadruple fungi Leishi elegantly chiselled raise the body to just the desired height; the handles are rain dragons gracefully arching their backs. The symbol of longevity in a round medallion supported by rain dragons treated in antique style is placed on each face; these decorations, so simple and grand, are chiselled in very low relief. The cover, rounded like a dome, terminates in a hollow knob decorated with a dragon. Four round medallions with symbols, around which are eight dragons, form a circular decoration on the cover, which is cut in openwork. The burnished yellow of a slightly green tone glows with deep and soft brilliancy, while the particles of beautiful yellow gold emit a powerful light. It must be admitted that this is a beautiful object worthy of a collection; it bears the mark of Hsüan-te with the classic inscription 'Ta Ming-sen-toku-ne-sei' (manufacture of the years of Hsüan-te of Great Ming, 14261435)." Carved teakwood stand.

II eight, $81 / 8$ inches; diameter, $85 / 8$ inches.

2020-ANTIQUE CHJNESE IBRONZE TASE

Bottle-shaped. Ornamented with palm leaf panels of archaic designs inlaid with fine silver wires; coated with a mottled patina.

From the Marquis Collection, Paris.

Height, 71/2 inches.

\section{1-OLD CHINESE BRONZE INCENSE BURNER}

Oval shape on four tall, slender legs. Archaic designs in relief casting and chiselled.

Height, 5 inches.

2028-OVIFORM VASE

Old Chinese bronze. Band of archaic patterns in relief casting; coated with a very fine mottled green and red patina.

Height, 81\% inches.

2023-ANTIQUE CHINESE BRONZE JAR

Globular shape, with loose ring handles on shoulder. Ornamented with bands of archaic designs in low relief and with malachite incrustations. Coated with a fine mottled red and green patina. Ming period. Has carved teakwood stand.

Height, 8 inches; diameter, 10 inches. 
2024-CHINESE BRONZE VASE

Ch'ien-lung period. Vase for a single flower, of yellow bronze; bottle form with spherical body and long delicate neck, decorated with a dragon in relief.

Height, 81/4 inches.

Exhibited at a Loan Exhibition, National Academy of Design, 1893.

2025-OLD CHINESE BRONZE VASE

Beaker-shaped, with scalloped edge. Dragon and cloud forms in relief casting round centre band. Mark of Ta Ming Hsüan-te nien chih underneath foot.

Hêight, $33 / 4$ inches.

2026-BRONZE INCENSE BURNER

Old Chinese. Design of steamship with figures of musicians on deck.

Length, 81/2 inches; height, 7 inches.

2027-BRONZE INCENSE BURNER

"Ch'ien-lung period. A tripod with two handles of 'dead-leaf yellow' bronze, with elephant motives. The body of the burner is round, deep and broad at the opening; it is decorated with a delicate grass and flower scroll and a Greek fret border.

" The three feet and the two handles are elephants' heads, with trappings that were inlaid with precious stones. The cover is a very high dome chiselled and pierced with the same but heavier Indian scroll than is on the body; it is surmounted by a seated elephant with housings bearing a presentation basket on his back." Carved teakwood stand.

Loan Exhibition, National Academy of Design, 1893.

II eight, $81 / 2$ inches.

202S-BRONZE OKIMONO

Bird of immortality, finely wrought in bronze.

Length, 9 inches.

2029-BRONZE FLOWER TASE

"Ch'ien-lung period. Bottle-shaped, round and large in the body, and tapering suddenly to form a neck similar to the Persian bulb-shaped vases - the neck, however, being shorter. Decorated with two rain dragons in high relief, rich in modelling, and full of life. Although of the late period of Ch'ien-lung, it is after the Shing-ti school." Carved teakwood stand.

Ileight, 91/4 inches; diameter, 7 inches.

Loan Exhibition, National Academy of Design, 1893. 
Old Chinese. Palmettes incised; covered with a rich mottled brown patina.

Height, 9 inches.

\section{1-LARGE BRONZE KETTLE}

" Chin-che to Lung. A tripod used by the ancient Chinese for food and beverages. This object is very peculiar in form. A round basin bulging like a drum, with the edges curved outward and depressed at one part to form a lip from which to pour liquids; on the side opposite to the lip is a handle formed by an animal's head; on the outside are three movable rings, held by chimeras. The vase is surrounded up to the neck by two circles; one bears a fine design, damascened in gold and silver. The larger and lower one bears a design of monsters' heads in low relief. The border of the rim has a silver thread, forming an undulating design. The feet are triangular, with circles and a coarse design in relief. The whole object is of a very ancient style. The patina is black, and the surface of the bronze coarse. The ancient Chinese never concerned themselves about verdigris; they cooked in bronze, they ate off hronze, and no disease was ever attributed to the bronze. They even boiled their medicinal herbs in bronze."

Height, 105/8 inches; diameter, 103/4 inches.

Loan Exhibition, National Academy of Design, 1893.

\section{2-INCENSE BURNER}

Old Chinese bronze. Double bird shape; inlaid with fine silver wires and coated with a mottled green and brown patina.

Height, 9 inches.

\section{3-ANTIQUE CHINESE BRONZE INCENSE BURNER}

Low oval shape, with lion head and loose ring handles. Ornamentation of fabulous animals, wave designs and cloud forms in relief casting. Cover of openwork design, dragons, phœnix and cloud forms. Six-character mark Ta Ming Hsüan-te nien chih under neath foot. Carved teakwood stand.

Height, 9 inches.

\section{4-CHINESE BRONZE INCENSE BURNER}

Lozenge shape on four slender leaf-shaped feet. Ornamented with incised floral designs. Openwork cover surmounted by a kylin. 
" Ming. Represents a Kirin with a cornet-shaped vase on his back, all of gilt bronze inlaid with precious stones. The body is covered with chiselled scales, which are in their turn almost entirely covered by flames executed in bold high relief. The numerous precious stones are inlaid and distributed in keeping with Chinese art. Their colors-red, white, blue, green, etc.-harmonize with the strong yellow gold of the background; each color displays its full intensity owing to their excellent combination. None of the stones impair the rich outline manipulated with so much boldness and vitality. The bottom displays a round patch, from which the original inscription has been taken and replaced by a plain gilded patch. A person in possession of an object having the Palace mark upon it was punished by death. No doubt that mark was removed and replaced by this smooth surface, which has been done so well as to make it hardly visible." Carved teakwood stand.

Loan Exhibition. National Academy of Design, 1893.

Height, 10 inches.

2036-TEMPLE LIBATION VESSEL

Helmet shape. Band of archaic designs in low relief; covered with a red and brown patina. Old Chinese. Signed in Sanskrit characters.

Height, 9 inches.

2037-ANTIQUE CHINESE VASE

Double bird shape, wrought in brass and gilded. Ornamentation of incrusted jade, lapis lazuli, agate and malachite. Underneath foot the Pao-Kua and other symbols engraved. Carved teakwood stand.

Height, 111/2 inches.

2038-ANTIQUE CHINESE VASE

Companion to the preceding.

2039-TEMPLE WINE VESSEL

Old Chinese bronze. Oviform on tripod support. Ornamented with incised archaic designs and coated with a mottled green and brown patina. Incised mark underneath cover. Teakwood stand.

Height, $93 / 4$ inches.

2040-YELLOW BRONZE INCENSE BURNER

Globular shape. Cover in design of a kylin's head. Old Chinese. 
Quadrilateral. Beaker-shaped, with raised ornaments and coated with a fine mottled green and brown patina.

$$
\text { Height, 91/2 inches. }
$$

2042-BOTTLE-SHAPED VASE

Old Chinese bronze. Globular body with wide tubular neck; ornamented with band of archaic designs and coated with a fine mottled red and green patina.

$$
\text { Height, 101/2 inches. }
$$

\section{3-BRONZE BOTTLE-SHAPED VASE}

With square mouth and tubular handles. Ornamented with bands of archaic designs in relief casting. Old Chinese.

Height, 11 inches.

\section{4-BRONZE ORNAMENTAL PIECE}

Elephant supporting a vase. Elaborate ornamentation in relief casting and incrusted with stones. Old Chinese.

Height, 11 inches.

\section{5-BRONZE INCENSE BURNER}

Old Chinese. Band of archaic design and palmettes incised and in low relief. Engraved mark underneath foot.

Height, 11 inches.

2046-ANTIQUE CHINESE BRONZE VASE

Tall slender quadrilateral shape. Ornamented with incised palmations and coated with a mottled red and brown patina. Ming period.

Height, 11 inches.

2047-OLD CHINESE BRONZE INCENSE BURNER

Tall oblong shape, with elaborate openwork cover and separate stand. Ornamentation of Koro cast in high relief and partially gilded. Signed, "Ta Ming Hsïan-te."

2048-ANTIQUE CHINESE FLOWER TASE

Height, 121/2 inches.

"Hsüan-te, 1426-1435. Represented by a bag made of a lotus leaf by drawing up the edges vertically and confining it in the middle by a cord. The stem of the leaf, tied down by two young leaves and stems, forms by its curves the foot of the vase. The veins of the leaf are in relief in vertical, graceful, undulating lines. The edge of the irregularly folded leaf presents a most natural appearance. There are in it also breaks and worm holes such as are always found on this plant. This is a masterpiece of cireperdue casting from a technical point of view. The reproduction 
in thin wax of so many irregularities would prove impossible to an ordinary artist. The author of this piece has distinguished himself, not only by his technic, but also by his originality; this work displays nobility of style, refinement of taste, and grace in design." Height, 103/4 inches.

Exhibited at a Loan Exhibition, National Academy of Design, 1893.

2049-BRONZE WATER POT

" K'ang-hsi, 1662-1722. In form of a sacrificial cup, the oval body rests on a straight and oval pedestal, and is joined to a neck of cup form with a broad lip; a delicate handle formed of a dragon's head with out-drawn tongue. The cover at the end and above the lip represents a grotesque animal with two horns; at the other extremity, near the handle, a tiger's head which, owing to its erect ears, resembles a cat. The whole is decorated with motives in ancient designs of dragons, lions, devils, etc., in bold relief on a Greek fret delicately chiselled; these motives are richly inlaid with gold and silver in fine and broad fillets. The bronze is black and the patina brilliant with a green tinge. The work is clear and the style bold. It is a return to the ancient bronzes and one of the best specimens of the bronzes of K'ang-hsi." Carved teakwood stand.

II eight, 105/8 inches; width, 11/1/2 inches.

Loan Exhibition, National Academy of Design, 1893.

2050-ANTIQUE CHINESE BRONZE T'ASE

Quadrilateral shape, with flaring mouth. Ornamented with four upright palmettes round neck. Coated with a fine red and brown patina. Ming period. Carved teakwood stand.

Height, 91/2 inches.

2051-OLD CHINESE BRONZE TRIPOD INCENSE BURNER

With rudimentary handles. The cover surmounted by a kylin.

Coated with a rich brown patina. Teakwood stand.

Height, 13 inches.

2052-SACRIFICIAL BASIN

"Ch'ien-lung, 1736-1795. In the form of a helmet with a handle and four feet. The orifice is very large and is decorated around the outer edge with a band of Greek fret in relief. The handle is a dragon without feet. The four feet of the basin are designs of tiger heads. The patina is bright chestnut."

$$
\text { II eight, 103/4 inches; length, } 18 \text { inches. }
$$

Loan Exhibition, National Academy of Design, 1893. 
2053-OLD CHINESE BRONZE OKIMONO

Seated figure of Kwan-on supported by a fabulous animal. Teakwood stand.

Height, 12 inches.

2054-ANCIENT CHINESE BRONZE VASE

Pilgrim bottle shape. Coated with an interesting mottled patina of verdigris-green and reddish brown.

Height, 12 inches.

\section{5-OLD CHINESE BRONZE INCENSE BURNER}

With openwork cover and stand. Ornamented with fabulous animals, wave designs and cloud forms in relief casting and gilded. Signed, "Ta Ming Hsüan-te."

Height, 12 inches.

2056-BRONZE FLOWER VASE

"Chinese. Seventeenth century. A square, bulging body of reddishbrown bronze, terminated by a short thick neck, with a base and two handles, of lions' heads, pierced for rings. It is decorated with horizontal bands of animals' heads in antique style; these bands encircle the neck, the shoulder, and the base; there are small vertical and projecting bars on the angles of these designs. On the body there is a series of long vertical pendants in low relief, regularly disposed, three on each face and one at each angle. The patina is very fine on the plain parts, and particularly so where it is clouded with red."

The bottom bears an inscription which reads as follows (the gem of long generations ):

$$
\begin{array}{lllllll}
3 & & & 1 & \text { yei- } & \text { long, eternal } \\
4 & \times & 1 & 2 & \text { sei- } & \text { generations } \\
& \times & 2 & 3 \text { no- } & \text { of } \\
& & & & \text { 4 Takara-precious object, gem. }
\end{array}
$$

Height, 111/2 inches; $71 / 2$ inches square.

Loan Exhibition, National Academy of Design, 1893.

\section{7-TEMPLE WINE VESSEL}

Old Chinese bronze. Ornamented with archaic designs in relief casting and inlaid with gold and silver. Coated with a mottled green and brown patina. 
"Hsüan-te, 1426-148\%. Jug-shaped, with a small short neck; decorated with two dragons in relief on the shoulders. The red of the polychrome patina is magnificent and the yellow of the background has a penetrating brilliancy. This is the style of bronze which has often been imitated in porcelain during the Yung Chêng period. This beautiful bronze belongs to the period of Hsüan-te at Chingwa of the dynasty of Ming. The inscription on the bottom is pronounced Ho-Ki, which signifies "precious use." Carved teakwood stand.

$$
\text { Height, 111/4 inches; diameter, 71/8 inches. }
$$

Loan Exhibition, National Academy of. Design, 1893.

\section{9-BRONZE FLOWER VASE}

"Ching-tih to Lung-king, 1506-1572. A low, flattened, spherical body with long, slender neck in inverted trumpet form; in the middle of the neck are two elephant heads forming handles. The bottom of the neck bears four cornet-shaped panels with a very delicate antique design. The patina is black and brilliant." Carved teakwood stand.

$$
\text { Height, 11/1/2 inches; diameter, } 71 / 4 \text { inches. }
$$

Loan Exhibition, National Academy of Design, 1893.

\section{0-BRONZE INCENSE BURNER}

Incense burner. About eighteenth century; the cover, about fifteenth century. A spherical cone of black bronze, resembling a pineapple. The fruit is entirely covered with a design of leaves, which are regular, in relief, and strongly accentuated. Itrests upon a foot of slender leaves, which join to form a stem near the body of the fruit, and spread apart, and roll back upon themselves at their lower extremity. There are twelve of these leaves, of which six are half the length of the others. The cover forms the apex of the cone, is tipped with an olive-shaped knob, and is pierced with three ventholes; the surface is smooth. The precise age of this bronze is a mystery. It is not as ancient as it appears; it can barely be one hundred years old; it is evident the cover is older than the body of the bronze, which dates probably from the commencement of the Ming period."

$$
\text { Height, 121/2 inches; diameter, } 8 \text { inches. }
$$

Loan Exhibition, National Academy of Design, 1893. 
Figure of priest holding in his right hand a shoe. Artistically modelled specimens. Finely carved teakwood stand of lotus and wave design.

Height, 12 inches.

\section{2-ANCIENT TEMPLE WINE. VESSEL}

Old Chinese bronze. Design of a fabulous animal; ornamented with archaic designs in relief casting and coated with a fine mottled patina. Teakwood stand.

Height, 121/2 inches.

\section{3-CHINESE BRONZE TEMPLE JAR}

"Ming, about Yung Lo, 1403-1425. Tall and square, inlaid with gold and silver; the body decreases in size until it reaches the base; the shoulders are indicated by an angle, and the neck, one-half of which is formed by the cover, describes on its face a concave line. The four angles and the centre of each panel of the body, cover, and base, bear rectangular vertical bars; the front and back face of shoulders are decorated with projecting tiger heads, and on the right and left panels are two handles composed of small dragons, curving their tails into rings. The roofing and knob of the cover are broken pyramids. The whole surface of the bronze is covered with silver inlay which has grown black. The patina is grayishblack and white in certain parts." Carved teakwood stand.

Height, 131/s inches; width, 81/2 inches.

Loan Exhibition, National Academy of Design, 1893.

2064-FLAT OVIFORM VASE

Old Chinese bronze. Ornamented with archaic designs in relief casting and incised. Covered with a fine mottled green and brown patina. Early Ming.

Height, 13 inches.

\section{5-ANCIENT BRONZE WINE VESSEL}

Design of a fabulous animaỉ. Archaic designs in relief casting. Old Chinese. Teakwood stand.

Height, 131/2 inches.

2066-BOTTLE-SHAPED VASE

Old Chinese bronze. Ornamented with archaic designs in palm leaf-shaped panels and on a band round the body.

Height, 111/2 inches. 
"A sitting Kirin in yellow Hsüan-te bronze with gold spots on the smooth, transparent patina. The head of the animal is raised, his eyes round and bulging, his nose flat, his jaws square and open, his horn and ears erect, the coat sharp and curly. The tail is erect and delicately chiselled, the hair dividing itself into eight strands. All over the upper part of the body are gold spots which enhance the beauty of the deep and transparent patina. The technic of this beautiful bronze is beyond reproach; it is in the perfect style of the first-class Hsüan-te bronzes."

$$
\text { Height, 113/4 inches; length, 123/4 inches. }
$$

Loan Exhibition, National Academy of Design, 1893.

\section{8-CHINESE BRONZE KORO}

"Nineteenth century. Represents two carps united at the belly, standing vertically on their tails, with heads transformed into dragons which form the cover. The fins, marked with coarse strokes, project outward. The back fins are quilled, making an openwork edge. The heads have the structure of the dragon, with double horns. This transformation is the result of a Chinese tradition which affirms that carps at certain periods become dragons, and under cover of the storm ascend to heaven. This idea of evolution is in allusion to the life of a man who attains an eminent position. This superstition existed also in Japan, and the carp was much used on occasions of congratulations."

Height, 121/2 inches.

Exhibited at a Loan Exhibition, National Academy, 1893.

2069--BRONZE FLOWER VASE

"Wan-li, 15\%3-1619. A beaker lozenge-shaped, decorated with 100 movable rings. The lower part is broad with a very slightly marked girdle and very flaring at the top. The lower part and the girdle are covered with a decoration of animals in bold antique design, on a Greek fret; the neck bears the antique cornulated design in the same style as the girdle. The rings are placed at equal distances in vertical lines, one at each angle and two on each panel. Under the edge of the orifice there are five rings, each column is composed of eight rings, making one hundred in all; each ring is secured to the vase by an eye."

$$
\text { Height, 131/4 inches; width, } 93 / 4 \text { inches. }
$$

Loan Exhibition, National Academy of Design, 1893. 
Antique Chinese. Tall oviform on a tripod of kylins. Two handles of dragons and loose rings. The cover surmounted by the figure of a kylin.

Height 14 inches.

2011-ANTIQUE BRONZE INCENSE BURNER

Design of a kylin with brocade ball. Old Chinese. Teakwood stand.

Height, 12 inches; length, 18 inches.

2072-BIONZE SACRIFICIAL VASE

"Sung. Represents a double ox bearing a slightly flattened cylindrical vase upon its back. It is composed of one body with four legs and two heads placed at opposite ends, so that one of the heads is where the tail ought to be. Each face is a perfect facsimile of the other; each head is crowned with a pair of horns curved and resting on the ears; and two protruding round eyes on the upper part of the face; the straight legs have a spiral scroll on the shoulder which indicates the muscle. On the back running up the neck are three lateral stripes inlaid with small plates of silver regularly laid in succession; the same decoration is repeated in parallel and vertical lines on the chest and belly; the head and legs are decorated with a large rounded Greek fret inlaid with silver. The cylinder has two bands encircling it: the first is narrow, the second broad, inlaid with an antique design of animals' heads. The silver inlaying is executed in broad, plain lines combined with very delicate ones, handled with great nicety. The patina is brown with green and red spots of quiet tone and soft lustre. The general work is a combination of bronze and silver, but gold is used in certain parts. This is a very important bronze; it is antique and well preserved; the form is original and of wellstudied proportions, and there is nothing grotesque in the originality of the subject; on the contrary, it impresses one with its grandeur, nobleness and beauty. Has a finely carved teakwood stand."

Height, 13 inches; width, 111/2 inches.

Loan Exhibition, National Academy of Design, 1893. 
"Beginning of Ming, before Hsüan-te, fourteenth century. Square and low in form with a very short neck, merely to support the cover, and a low base supported by four feet; each foot represents an eagle perched on a standing monkey. The handles are rain dragons with prominent ears. The cover is of pierced scrollwork crowned with a square hollow pierced knob. The whole is inlaid with gold and silver. The patina is black, in several places greenish-red. It bears the following inscription:

“ 'May my sons and my grandsons preserve this forever

"(as a precious (object)." "

Height, $13 \frac{1}{3}$ inches; width, $15 \frac{1}{2} / 2$ inches:

Loan Exhibition, National Academy of Design, 1893.

\section{4-CHINESE BRONZE INCENSE BURNER}

"Chinese. Fifteenth century. Shape oblong, standing upon four legs; dragon handles. The body is ornamented in relief with dragons, amid cloud forms and fire emblems, chasing the Pearl of Omnipotence, on the cover of which, of openwork, in similar designs, rests a grotesque animal with its cub. Six-character mark of Hsüan-te. Fine teakwood stand with carved jade panel."

Height, 13 inches; width, 10 inches.

Loan Exhibition, National Academy of Design, 1893.

2075-CHINESE BRONZE INCENSE BURNER

" Ming, or previous. In the form of the bird Hōwō, standing upon a leaf, bearing upon its back a vase with a large opening, the cover of which follows the outlines of the vase, describing four lobes; it is rounded, pierced, and surmounted by a sitting stag. The bronze is thick and very heavy and in bold relief. Designs upon the cover of bats flying in the clouds. The heavy but artistic form with the perfect grouping is of the character and style of those of Shing-ti period, 1426-1435."

Height, 15\% inches; width, $97 / 8$ inches.

Loan Exhibition, National Academy of Design, 1893.

2076-BOTTLE-SHAPED VASE

With dragon-head handles on shoulder. Bands of archaic designs incised. Old Chinese bronze. 
"Tang, between the ninth and tenth centuries. Square, bulging and increasing in size towards the middle, contracting gradually at the throat, which is half the diameter of the body. Two rings held by devil's heads decorate the two sides. The entire surface is covered with a fine design of inlaid silver completely oxidized; the parts that are visible present a gray tint. It is further inlaid with gold and turquoise. The patina is dark brown and composed of the most variegated tones: green, brown, dead-leaf, and at times white. The metal is a red bronze containing the precious metals. This is what distinguishes the bronze antecedent to the Sung period from those of Yung and Ming."

Height, 145/8 inches; $73 / 4$ inches square.

Loan Exhibition, National Academy of Design, 1893.

\section{8-OLD CHINESE BRONZE TRIPOD INCENSE BURNER}

On supports of elephant heads. Openwork cover of lotus and vine design, which is surmounted by a recumbent elephant supporting a small vase. Incrusted with imitation jewels.

Height, 141/2 inches.

\section{0\%9-LARGE BRONZE INCENSE BURNER}

Design of a Kylin. Ornamented with peony, butterflies and vines, which are inlaid with fine silver wires. Old Chinese.

Height, 151/2 inches.

2080-OLD CHINESE BRONZE INCENSE BURNER

Design of a horse. Coated with a rich brown patina.

Height, 14 inches.

\section{1-CIIINESE BRONZE KORO}

"Sung, 1196-1278. A double cylinder grouped with a tiger, an eagle, and a dragon, emblems of the power and strength of the sky and earth and the air. Inlaid with gold and silver wires, and coated with a fine verdigris and mottled red patina. Carved teakwood stand."

Height, 15 inches.

Loan Exhibition, National Academy of Design, 1893. 
"Sung, 1196-1278. A beautiful specimen of black bronze; round and tall, with neck and pedestal. Four vertical lines in relief, cut in saw teeth, divide the vase into four faces; two horizontal lines at the joining of the shoulder and the base divide the antique and classic designs into three rows. Two rain dragons on the neck form the handles. The designs of the decoration are in low relief upon an entire background of repeated Greek fret. The patina is unusually fine." Teakwood stand.

Height, 17\% inches; diameter, 10 inches.

Loan Exhibition, National Academy of Design, 1893.

\section{3-LARGE BRONZE INCENSE BURNER}

Melon shape on tripod. Relief ornaments of mountain goat and young surmounting the cover; archaic design handles. Chinese. Fifteenth century. Carved teakwood stand.

Height, 16 inches; width, 17 inches.

2084-ANTIQUE BRONZE INCENSE BURNER

Design of fabulous animal. Old Chinese.

II eight, 17 inches.

2085-BRONZE FLOWER VASE

"Sung. Reign of Kiso, 1101-1126. Its form is high and bulging in the lower part of the body which contracts to form the neck, which in its turn flares at the aperture. To form the base the body contracts suddenly. It is rectangular, rounded at the corners. The triangular bands which divide the body into eight medallions simulate a rope network. The handles are rain dragons proudly raising themselves from the neck to the opening. The designs in broad scrolls are inlaid with gold and silver; the last, oxidized by time, is gray; the gold still retains the full power of its color. The dark patina is entirely covered with clouds of red and green. This vase must have been splendid in its day, and the patina acquired by time has rendered it more impressive still. The inscription is "May my sons, my grandsons preserve this forever (as a) precious (object)." " The casting of this piece is remarkable for its thinness, and is a masterpiece of not only that but of any other period. Finely carved teakwood stand.

Height, 171/2 inches; width, 111/2 inches.

Loan Exhibition, National Academy of Design, 1893. 
"About Chia-ching, 1522-1566. Of maroon-brown bronze. Very tall, slender, and square, with two handles. The square body rounded at the angles is larger at the top than at the bottom, the outline curves gracefully from top to bottom; it has a double shoulder decorated with a necklet of chrysanthemum petals limited by two horizontal lines; from this springs the neck, long and contracted, ending with the edge of the aperture, which is decorated with a Greek fret. The base bears the same decoration as the shoulder, but reduced in size; the base as it were repeating the shoulder, rests on a square pedestal lower than it is broad and decorated in symmetrical apposition, with a design similar to the necklet; this is supported by a base decorated with a Greek fret. The handles fastened to the neck are rain dragons. On each face below the shoulder is a medallion in relief in the form of a screen, in design contorted rain dragons with the character $j u$ in the centre. The work is sharp, neat and rich, and the patina brilliant, soft and deep." Teakwood stand.

NoтE.-This style of dragon composition is also found on the bronzes of Hsïan-te.

Height, 181/2 inches; diameter, $4 \frac{1}{2}$ inches.

Loan Exhibition, National Academy of Design, 1893.

2087-ANTIQUE CHINESE BRONZE VASE

Tall bottle shape, with slender, tubular neck; dragon ornament in relief on neck and shoulder. Coated with a very fine mottled red and brown patina. Carved teakwood stand.

Height, 18 inches.

\section{8-ANTIQUE CHINESE BRONZE VASE}

Tall, slender oviform, with loose ring handles. Ornamented with bands of palmations and archaic borders in low relief casting and chiselled. Covered with a fine mottled brown and red patina.

Height, 25 inches.

2089-LARGE BRONZE JAR

"Sung, 1127-1279. Square in form. At the angles and in the centre of each panel are projecting partitions standing vertically, and two saw teeth projections decorate the upper extremity of each partition. The handles are dragon's heads with enormous tongues drawn out, forming a semicircle of rectangular flat strips. The cover is a truncated pyramid surmounted by a knob of the same 
form. The decoration represents six feet enriched with designs of devil's heads and birds on a background of composite Greek fret. The animals are inlaid with gold and silver in broad and fine lines. The patina is nearly black and in some places imperfect. In olden times these jars were used as incense burners; the custom of piercing covers has only been practised since the commencement of the Ming period."

Height, 233/8 inches; width, 16 inches.

Loan Exhibition, National Academy of Design, 1893.

\section{0-ANTIQUE CHINESE BRONZE VASE}

Tall oviform, with lizard and loose ring handles, silk cords and tassels. Ornamented with a gadroon border round shoulder and a band of incised Greek fret round the neck. Coated with a very fine mottled green and red patina.

Height, 251/2 inches.

\section{1-ANCIENT CHINESE BRONZE VASE}

Tall shape; inscription and bamboo branches in relief. Coated with a mottled glaze.

Height, 27 inches.

\section{2-MAMMOTH INCENSE BURNER}

Old Chinese bronze. Globular shape, with bold scroll handles, and on a tripod support. Covered with an openwork design of the Eight Triagrams and surmounted by a kylin playing with brocade ball.

Héight, 29 inches; width, 18 inches.

\section{3-CHINESE BRONZE INCENSE BURNER}

"Wan-li, 15\%3-1619. Of black bronze; in form a jar with large cylindrical neck, three feet, two handles (elephants' heads), and rounded cover surmounted by a lion. The body is vertically divided into minute projecting lobes which simulate a chrysanthemum. On the neck is a low relief in an angular dragon design on a background of fine Greek fret. The handles are inverted elephants' heads, the feet are also elephants' heads. The cover is pierced with large apertures and is crowned with a sitting lion raising his head expressively and holding a ball under his paw." Handsomely carved teakwood stand.

$$
\text { Height, } 34 \text { inches; diameter, } 21 \text { inches. }
$$

Loan Exhibition, National Academy of Design, 1893. 
"Ming of Ch'êng-hua to Chia-ching, 1465-1521. A column dividing two hexagonal cups supported by a statue representing a Kongo (the Hercules of Buddhism) on a hexagonal stand with three legs. The strong man has a bearded face and round eyes, the nude body wears a conventional skirt. The chest has the breasts well defined and is decorated with a necklace, the waist is banded by a ribbon, bracelets are on the upper and forearm. A broad ribbon scarf rises above the shoulders and falls low on either side. He holds the largest cup on his head, steadying it with one hand, the other rests on his hips. He kneels on one knee. The upright sides of the cups are decorated with simple designs of plants in relief; each hexagonal column also bears two rain dragons. The three feet are lions' heads with long tongues resembling elephants' trunks. The upper cup contains the point on which the candle is stuck (In China and Japan the candles are hollow at the bottom for this purpose). The bronze is black with no brilliancy in the patina. The important part of this bronze is the figure, which is designed in a highly archaic style." With tall stands and extra carved teakwood stand.

Loan Exhibition, National Academy of Design, 1893.

Height, 45 inches.

\section{ANTIQUE CHINESE CLOISONNÉ AND OTHER ENAMELS AND CHAMPLEVÉ}

2095-PEKING ENAMEL CUP AND SAUCER

Mythological subjects, imitating the Italian style, painted in

panels, which are surrounded by passion flowers; exquisitely executed in delicately combined colors on brass.

\section{6-PEKING ENAMEL SAUCER}

Similar in ornamentation and workmanship to the preceding.

209\%-PERFUME BOX

Japanese cloisonné enamel. Morning glories, bird and other designs on a red and black enamel ground.

\section{8-OLD CHINESE HANGING INCENSE BURNER}

Bird on a branch; bronze and enamel. 
2099-OLD CHINESE INCENSE BURNER

Design of a nondescript bird on wheels; wrought in bronze and enamelled.

2100-WRITER'S PENCIL AND INK-HOLDER

Old Japanese cloisonné enamel.

2101-SMALL QUADRILATERAL VASE

Old Chinese enamel. Dragon crest, birds and cloud forms in various enamels on an opaque ground.

Height, 31/2 inches.

2102-SMALL CYLINDRICAL VASE

Old Japanese cloisonné enamel. Birds, flowers and rocks in low tones of enamels on an opaque ground.

Height, 4 inches.

2103-OLD CHINESE INCENSE BURNER

Globular-shaped. Cloisonné enamel on bronze and partially gilded. Ming period.

Diameter, 4 inches.

2104-OLD CHINESE COPPER FLOWER VASE

Oviform. Floral scrolls in various enamels. Carved teakwood stand.

Height, 4 inches.

2105-CYLINDRICAL VASE

Chinese cloisonné enamel. Landscapes in panels, surrounded by crests and symbols on a turquoise-blue ground. Ch'ien-lung period.

Height, 4 inches.

2106-OLD CHINESE CHAMPLEVÉ GLOBULAR BOX

Archaic designs in red, blue, orange and white enamels. Interior surface gilded. Early Ming.

Diameter, $41 / 2$ inches.

210\%-TRIPOD INCENSE BURNER

Old Chinese cloisonné enamel. Inscriptions and archaic designs in dark blue, red and yellow enamels on a turquoise-blue ground. Carved brass mountings and openwork cover. K'ang-shi period. Has teakwood stand. 
Old Chinese cloisonné enamel. Floral sprays and crests in red, blue and white enamels on a turquoise-blue ground. Early Ming. Four-character mark underneath foot. Has teakwood stand.

$$
\text { Height, 41/2 inches. }
$$

\section{9-CLOISONNÉ TRIPOD INCENSE BURNER}

Semi-globular shape with top handles; floral designs in Indian red, ivory white and dark blue on a turquoise-blue ground. Ming period. Openwork teakwood cover.

Diameter, $4 \frac{1}{2}$ inches.

2110-ANTIQUE CHAMPLEVÉ BOX

Lotus flower design; the stem and branches forming support. Ming period.

$$
\text { Height, 41/2 inches. }
$$

\section{1-BOWL ON HIGH FOOT}

Chinese cloisonné enamel. B-anches of flowers and blossoms, panels of domestic animals, scrolls and other designs in bright enamels on a turquoise-blue ground. Ch'ien-lung period.

Height, 5 inches.

\section{2-TRIPOD INCENSE BURNER}

Old Chinese cloisonné enamel. Globular-shaped, with top handles. Sacred flowers amid leafy scrolls in red, green, blue and white enamels on a turquoise-blue ground. Ch'ien-lung period. Openwork teakwood cover and stand.

Height, 5 inches.

2113-OLD CHAMPLEVÉ STATUETTE

A kneeling monkey. Ming period. Teakwood stand.

Height, 5 inches.

\section{4-CLOISONNÉ ENAMEL STAND}

Oblong-shaped. Scroll and floral designs in finely combined enamels on a turquoise-blue ground. Ch'ien-lung period.

Height, 3 inches; length, 51/2 inches.

\section{5-CHINESE INCENSE BURNER}

Design of an elephant. Bronze and enamel. 
Old Chinese bronze, with leaf-shaped panels and floral band in cloisonné enamel. Teakwood cover with Feit-su jade ornament, and teakwood stand.

\section{7-HEAVY BRONZE BOX}

Flat oblong-shaped. Outer surface of cloisonné enamel. An imperial dragon, the Pearl of Omnipotence, fire emblems and cloud forms in various colors on a dark blue ground. Interior plated with gold. Ch'ien-lung period.

Width, 6 inches; length, $71 / 2$ inches.

2118-BOWL ON TALL FOOT

Old Japanese cloisonné enamel (Shippo ware). Crests, diapers and floral designs in low tones of enamels on a dark green ground. Gilded rim.

Diameter, 61/2 inches.

2119-OCTAGONAL TRAY

Old Japanese cloisonné enamel. Dragon, symbols and arabesques in low tones of enamel on a dark green ground.

Diameter, 61/2 inches.

2120-WALL VASE

Old Chinese cloisonné enamel. Bat symbol and floral scrolls in various enamels on a turquoise-blue ground. Ch'ien-lung period. Height, $61 / 2$ inches.

\section{1-RING-SHAPED BOX}

With hinge and clasp. Old Chinese cloisonné enamel. Inscriptions and archaic designs in red, dark blue, white and gray enamels on a turquoise-blue ground. The inner surface, hinge and clasp heavily gilded. Ming period.

Diameter; 7 inches.

\section{2-GLOBULAR INCENSE BURNER}

On tripod. Old Chinese cloisonné enamel. Clusters of grapes and floral crests in low tones of red and blue enamel on a turquoise-blue ground. Has a carved wood cover surmounted by a jade ornament and carved wood stand. 
Circular shape on tripod. Branches of fruit in fine old colors on a blue ground, surrounded by a border of floral designs. Early Ming period.

Diameter, 7 inches.

\section{4-CHINESE CLOISONNÉ ENAMEL VASE}

Bottle-shaped. Dragon and fire emblems in red and cloud forms. in blue on a gray ground. K'ang-shi period.

Height, 7 inches.

2125-OLD CHINESE CHAMPLEVÉ VASE

Double lozenge-shaped. Archaic and floral designs in various enamels on a dark blue and turquoise-blue ground. Teakwood stand.

$$
\text { Height, 71/2 inches. }
$$

2126-OLD CHINESE CLOISONNÉ ENAMEL BOX

In three sections. Design of two monomonos supporting three rolled up kakemonos. The side of the monomonos are enamelled in white to represent the edges of a book. The base and other portions of the box are enamelled in conventional patterns in red, blue and yellow. Ch'ien-lung period.

Height, 8 inches; length, 8 inches.

\section{2'Y-UNIQUE WATER BOTTLE}

Old Chinese champlevé. Design of a fabulous animal. Ming period. Carved stand in design of turbulent water.

Length, $71 / 2$ inches.

2128-PEKING ENAMEL BOWL

Sea-green ground, with lotus plants and aquatic birds finely painted in bright colors. Yung Chêng character mark underneath foot.

Diameter, $71 / 2$ inches.

2129-PAIR OVIFORM TEA JARS

Old Japanese cloisonné enamel. (Shippo ware.)

Height 10 inches.

2130-LARGE BOWL

Old Chinese cloisonné enamel. Sacred flowers amid leafy scrolls in dark red, blue and other enamels on a turquoise-blue ground; etched band round foot. Four-character mark of Ming period underneath foot. 
Old Chinese cloisonné enamel. Archaic designs, Greek fret and palm leaf bands and floral scrolls in various enamels on a light blue ground. Rudimentary and loose ring handles on shoulder. K'anghsi period. Teakwood stand.

Height, 71/2 inches.

2132-OLD CHINESE CLOISONNÉ BOX

Companion to the preceding.

2133-PEKING ENAMEL-COVERED VASE

Goblet-shaped. Floral scrolls and various borders painted in bright colors on a yellow ground. Ch'ien-lung period.

Height, 9 inches.

2134-OLD CHINESE GOURD-SHAPED VASE

Repoussé brass, gilded; incrusted with coral, malachite, jade, turquoise and other stones. Ch'ien-lung period.

Height, 101/2 inches.

\section{5-TEMPLE ALTAR ORNAMENT}

Design of the sacred lotus. Old Chinese champlevé.

Height, 9 inches.

\section{6-ORIENTAL METAL-WORK TRAY}

Filigree silver border, with an ornamentation of fishes and shells in translucent enamels.

Diameter, 9 inches.

2137-BEAKER-SHAPED VASE

Old Chinese champlevé. Archaic designs in dark blue, white and green enamels on a turquoise-blue ground; gilded ornaments and bands. Ming dynasty. Carved teakwood stand.

Height, $9 \frac{1}{2}$ inches.

\section{8-LEAF-SHAPED DISH}

Old Chinese champlevé. Green and gray enamel ground; gilded ornaments. Finely carved teakwood stand. 
A bird on movable wheels, supporting a low beaker-shaped vase. Floral scrolls and other designs in finely combined enamels; gilded band and ornaments. Carved teakwood stand.

Height, 71/2 inches.

\section{0-GALIPOT VASE}

Old Chinese cloisonné enamel. Floral panels, inscriptions, symbols and other designs in red, dark blue, jade, green and other enamels on a light blue ground. Band of sceptre heads round shoulder and gadroons around the foot. Ming period. Teakwood stand.

Height, 12 inches.

2141-BEAKER-SHAPED VASE

Old Chinese cloisonné enamel. Various symbols of happy omen, floral scrolls and palm leaf bands, in various bright enamels on a turquoise-blue ground. Ch'ien-lung period.

Height, 101/2 inches.

2142-BEAKER-SHAPED VASE

To match the preceding.

2148-TEMPLE WINE VESSEL

Old Chinese champlevé. Design of a fabulous animal; gilded ornaments. Has carved teakwood stand.

Height, 10 inches; length, 13 inches.

\section{4-LARGE INCENSE BURNER}

Old Chinese cloisonné enamel. Globular-shaped, on tripod. Various symbols of happy omen, cloud forms and other designs on a turquoise-blue ground. Wide band of sceptre heads round shoulder. Openwork cover. Carved teakwood stand.

Height, 15 inches.

\section{5-JAPANESE CLOISONNÉ ENAMEL PLAQUE}

Imperial crest and scroll designs in dark blue, green, yellow and pink enamels on a white ground.

Diameter, 12 inches.

2146-PAIR OLD CHINESE VASES

Oviform-shaped; bronze with enamel ornamentation.

Height, 12 inches. 
Antique Chinese cloisonné enamel. Pilgrim bottle-shaped. Deer, stork, flowers and cloud forms in various colors of enamel on a turquoise-blue ground. Band of palmations round neck; gilded rims. K'ang-hsi period. Carved teakwood stand.

Height, 14 inches.

2148-IMPERIAL PEKING ENAMEL VASE

Hexagonal body with trumpet-shaped neck. On six panels is a decoration of European subjects and floral sprays finely painted in delicate colors; bands of floral scrolls encircling the neck; the whole decoration on a pale buff-color ground. Ch'ien-lung period. Imperial seal mark pencilled in cobalt blue underneath the foot.

Height, 13 inches.

2149-OLD JAPANESE INCENSE BURNER

Lotus design. Artistically wrought in copper and enamelled in low tones.

Height, 12 inches.

2150-PEKING ENAMEL PLAQUE

Decoration of dragons amid cloud forms and fire emblems chasing

the Pearl of Omnipotence; finely painted in bright colors-the dominant colors being blue, yellow and green. Ch'ien-lung period. Diameter, 131/2 inches.

2151-PAIR ALTAR CANDLESTICKS

Old Chinese cloisonné enamel. Various symbols of happy omen, floral scrolls and sceptre-head borders in finely combined colors of enamel on a light blue ground. Ch'ien-lung period.

Height, 13 inches.

2152-UNIQUE SPECIMEN OF ENAMEL

Old Chinese. Design of the royal bird Hōwō, finely wrought in chiselled and gilded bronze. The wings and tail feathers are all in green, blue and white and purple enamels, and the body is of red enamel. An extraordinary specimen of skilful workmanship of the Ming period.

Length, 18 inches; height, 9 inches.

2153-TALL BEAKER-SHAPED VASE

Old Chinese cloisonné enamel. Haoun-teen faces, palm-leaf panels and floral scrolls in low tones of enamels on a light blue ground. Ming period. Carved teakwood stand. 
Noble gourd-shape. Birds and flowers exquisitely painted in two panels; surrounded by an elaborate decoration of gourd vine in bearing, floral scrolls and butterflies finely painted in beautifully combined colors on a stippled yellow ground. Ch'ien-lung period. Carved teakwood stand inlaid with fine silver wires.

Height, 24, inches.

\section{5- LARGE INCENSE BURNER}

Old Chinese gilded bronze. Design of a branch of peach fruit. The symbolical bat and other ornamentation in incrusted agate. Has carved teakwood stand.

Height, 12 inches; length 17 inches.

\section{6-PAIR ANTIQUE CHINESE CLOISONNÉ ENAMEL JARDINIÈRES}

Globular melon-shaped. Landscapes, mountain scenery, river and palace views in bleu de Nankin and white enamels. K'ang-hsi period.

Height, 91/2 inches; diameter, 18 inches.

\section{5\%-ANTIQUE CHINESE CLOISONNÉ ENAMEL PLAQUE}

Garden scene: numerous figures, rocks and trees in low tones of red, blue, yellow, green and white on a turquoise-blue ground. Ming period. Framed.

Length, 25 inches; width, 16 inches.

\section{8-PAIR ELABORATE BUDDHISTIC ALTAR ORNAMENTS}

Old Chinese champlevé. Design of a sacred elephant supporting a vase, from which cloud forms are ascending, and forming supports to various symbols of happy omen. The whole mounted on an elaborate stand to conform. Has extra stand of carved teakwood.

Height, 28 inches.

\section{9-GRAND CLOISONNÉ ENAMEL PANEL}

Of the imperial Ch'ien-lung period. Shaped in design of a sceptre head. An elaborate embellishment consists of numerous vases of flowering plants and dishes of fruits executed in enamels to imitate the texture of porcelains and the natural colors of the fruits and flowers, and with a background of turquoise-blue enamel which is covered with a diaper pattern in gilded wires. In the upper right-hand corner is an inscription in Chinese characters 
of which the following is a translation: "The Imperial Court is filled with cheerfulness, and the green meadows with spring air." Signed, "Ming Tsûng." The panel is surrounded by a frame of gilded brass, which has a finely chiselled ornamentation consisting of the symbols of happy omen and cloud forms.

Height, 30 inches; length, 42 inches.

Looted from the Summer Palace at Pekin, 1860, and until 1890 in the wellknown Albert Heard Collection, Boston.

2160-ENGRAVED PANEL

Old Japanese white metal panel. A Buddhistic ceremonial subject artistically engraved, by Rikei. 1880. Framed in carved rosewood.

Height, 101/2 inches; length, 251/2 inches.

2161-JAPANESE DECORATIVE PANEL

Green lacquered ground, with lotus plants, a helmet-shape vase and a dragon-fly executed in cloisonné and ivory; tortoise-shell and mother-of-pearl inlays. Frame of teakwood beautifully carved and ornamented with various metals, ivory and mother-of-pearl. Signed by Ran Sui. Has an outer frame of rosewood.

Height, 12 inches; length, 13 inches.

\section{SHRINES AND BUDDHISTIC STATUES}

2162-POCKET SHRINE

"Shrine of Kwan-on Sama Vidi." Red lacquer. Containing an intricately carved and gilded figure of a six-armed Kwan-on seated on the sacred lotus.

2163-MINIATURE SHRINE

Black lacquer, with gilded interior. Containing finely carved figure of Buddha seated on a lotus flower.

2164-MINIATURE SHRINE

Black lacquer. Containing finely carved statuette of the threefaced god Mari-shi-ten, the defender of Buddha.

2165-JAPANESE IRON SHRINE

Design of temple drum on a standard, inlaid with gold crests of Tokugawa. Contains a miniature figure in carved white jade. 
Black lacquer, with gilded interior. Contains a carved wood and enamel figure of Shōki. Seventeenth century.

\section{7-JAPANESE SHRINE}

Finely carved bamboo. Contains a bronze figure of Buddha with an openwork halo on a carved wood stand.

\section{8-JAPANESE SHRINE}

Black lacquer, with gilded interior. Contains an elaborate carving, representing mountain scenery with numerous minute figures, and animals, together with a miniature shrine containing an eightarmed Buddha and Buddhistic symbols.

\section{9-JAPANESE SHRINE}

Temple design ; finely carved, lacquered and gilded.

Height, 25 inches.

21\%0-JAPANESE SHRINE

Pagoda design ; finely lacquered and ornamented with floral designs in cloisonné enamel.

Height, 27 inches.

2171-ANCIENT JAPANESE SHRINE

Black and gold lacquer. Containing finely carved and gilded seated figure of Buddha and two attendants.

Height, 22 inches.

\section{2-ANCIENT JAPANESE SHRINE}

Black lacquer with gilded interior. Contains a figure of Buddha seated on a lotus and with a halo background. Mounted on a group of stands; all finely carved and gilded.

Height, 28 inches.

\section{3-LARGE TEMPLE SHRINE}

Ancient Japanese. Black lacquer with gilded interior. Contains a figure of Buddha seated on a lotus base and with an elaborately carved halo; all richly gilded. Seventeenth century.

Height, 40 inches.

\section{1\%4-STATUE OF BUDDHA}

Standing figure with halo on a lotus design base. Carved and gilded wood. 
2175-STATUETTE

Figure of Buddha standing on a lotus-shaped base of carved wood, which is richly gilded and tinted with pigments. Nineteenth century.

Height, 291/2 inches.

\section{6-BUDDHISTIC STATUETTE}

Carved and gilded wood. Figure of Buddha standing on a lotus flower and with halo.

Height, 31 inches.

\section{7-BUDDHISTIC STATUETTE}

Carved and gilded wood. Figure of Buddha on sacred lotus, with carved openwork halo background. Nineteenth century.

Height, 23 inches.

2178-STATUETTE OF BUDDHA

Standing figure on a lotus design base and with elaborate background.

Height, 263/4 inches.

2179-STATUETTE OF BUDDHA

Standing figure on a base of lotus design and with an openwork halo as background. Carved and gilded wood.

Height, 301/2 inches.

2180-STATUETTE OF BUDDHA

Carved and gilded wood; on elaborate base of lotus and openwork design.

Height, 29 inches.

\section{1-BUDDHISTIC STATUETTE}

Standing figure of a Buddha, with an elaborate halo or background; mounted on a tall stand of lotus and openwork design; all of which are finely carved and gilded. Nineteenth century.

Height, 341/2 inches.

2182-STATUETTE OF BUDDHA

Carved and gilded wood. Standing figure with an elaborate halo, mounted on a base of lotus design, which is supported by a figure of Dog Foo. 
Carved and gilded wood. Buddha ("Kiyaku-Mujoo") with an elaborate halo, seated on the sacred lotus and supported by a peacock with spreading tail, which forms a background for the halo. The whole mounted on an elaborate base. Sixteenth century:

Height, 41 inches.

\section{4-BUDDHISTIC STATUETTE}

Carved and gilded wood. "Thousand-armed Buddha," with an elaborate halo or background and mounted on a base of lotus and openwork design.

$$
\text { Height, } 25 \text { inches. }
$$

\section{5-BUDDHISTIC GROUP}

Carved and gilded wood. Buddha and two attendants. Nineteenth century.

Height, 29 inches.

\section{6-BUDDHISTIC GROUP}

Carved and gilded wood. A seated figure of Buddha with halo; mounted on an elaborate stand.

Height, 18 inches; width, 16 inches.

\section{8\%—BUDDHISTIC GROUP}

Representing two devotional Buddhas with halos and elaborate stands. Of carved wood and richly gilded.

Height, 191/2 inches; width, 14 inches.

\section{8-BUDDHISTIC SHRINE ORNAMENT}

Carved and gilded wood. Two figures of Buddha seated on the sacred lotus, mounted on an elaborate stand.

Height, 21 inches; width, 18 inches.

2189-CARVED WOOD FIGURE

Buddha with halo, seated on a base of lotus design. Nineteenth century.

Height, 33 inches.

2190-CARVED WOOD BUDDHISTIC FIGURE

Gilded. Buddha, with halo, seated on a lotus base. Nineteenth century.

Height, 301/2 inches.

2191-ELABORATE TEMPLE IDOL

Kwan-on, seated on sacred lotus, and with a halo. Of carved and gilded wood. Has an extra stand of carved teakwood. 
2192-SHRINE STATUETTTE

Carved wood and gilded. Standing figure of Buddha on lotus flower, with elaborate halo background.

Height, 311/2 inches.

2193-BUDDHISTIC STATUETTE

Carved and gilded wood. Figure of Buddha standing on the sacred lotus. Elaborate halo and background.

Height, 30 inches.

2194-BUDDHISTIC FIGURE

Carved and gilded wood. Kwan-on seated on a sacred lotus, and with an elaborate halo background.

Height, 27 inches.

\section{5-LARGE TEMPLE SHRINE}

Black lacquered, with chased bronze mountings. The inner surface finished in applied gold leaf polished, and the altar interior ornamentation and accessories of finely carved wood. Gilded and tinted with enamel colors.

Height, 69 inches; width, 37 inches. 



\section{NINTH AFTERNOON'S SALE \\ AT THE AMERICAN ART GALLERIES \\ FRIDAY，JANUARY 26тн, 1906 \\ BEGINNING AT 2.30 o'CLOCK}

\section{JAPANESE ANTIQUE SWORDS AND ARMOR}

2196- ANTIQUE JAPANESE WARRIOR'S MASK

Repoussé iron; with throat protector.

2197-ANTIQUE JAPANESE WARRIOR'S MASK

Skilfully wrought in iron; throat protector attached.

2198-ANTIQUE JAPANESE WARRIOR'S MASK

Finely wrought in iron.

2199-ANTIQUE JAPANESE WARRIOR'S MASK

Repoussé iron; with throat protector.

2200-WARRIOR'S HALF MASK

Antique Japanese repoussé iron.

2201-ANTIQUE JAPANESE WARRIOR'S MASK

Wrought in repoussé iron; with throat protector.

2202-ANTIQUE JAPANESE WARRIOR'S MASK

Wrought in iron. 
2203-ANTIQUE JAPANESE WAR MASK

Extraordinary specimen of repoussé iron. By Miochin Nobuiye. 1515-1555.

2204-ANTIQUE JAPANESE WARRIOR'S MASK

Finely wrought in iron; with throat protector.

2205-ANTIQUE JAPANESE WARRIOR'S MASK

Repoussé iron; with throat protector.

2206-ANTIQUE JAPANESE WAR MASK

Finely wrought in iron; throat protector attached.

220\%-ANTIQUE JAPANESE MASK

Face of demon in repoussé iron.

2208-ANTIQUE JAPANESE WAR MASK

Finely wrought in repoussé iron; throat protector attached.

2209-ANTIQUE JAPANESE WARRIOR'S HELMET

Finely wrought in iron. Articulated dragon-fly ornament. Attributed to Miochin Umetada, 1583-1630. Inscription inside.

2210-ANTIQUE IRON WARRIOR'S HALF MASK

Repoussé workmanship; throat protector attached. Old Japanese.

2211-ANTIQUE JAPANESE WAR HAT

Iron. Legendary subject in repoussé.

2212-ANTIQUE JAPANESE WAR HAT

Finely executed in repoussé iron. Dragon in relief. By Miochin.

2213-ANTIQUE JAPANESE WARRIOR'S HELMET

Wrought in various metals.

2214-ANTIQUE JAPANESE WARRIOR'S HELMET

Wrought in repoussé, white metal, brass and red leather.

2215-ANTIQUE JAPANESE WARRIOR'S HELMET

In various metals, lacquered and gilt. 
2216-ANTIQUE WARRIOR'S HELMET

Japanese. Finely wrought in various metals and leather.

2217-ANTIQUE JAPANESE WARRIOR'S HELMET

Lacquered and gilt metal.

2218-WARRIOR'S BREASTPLATE

Antique Japanese iron. Head of a two-horned dragon in bold repoussé. By Munetora. Dated 3d year of Yenkio (1746, 2nd month). Signed, "Masudo Miochin, Shuri Ki Munetora Korewo tsukuru."

2219-ANTIQUE JAPANESE WAR LANCE

Staff covered with elaborate metal-work.

2220-ANTIQUE JAPANESE WAR LANCE

Long black lacquer staff.

2221-ANTIQUE JAPANESE LANCE

Double-edge blade. Staff incrusted with mother-of-pearl.

2R22-ANTIQUE JAPANESE LANCE

Three-cornered blade. Lacquered and mother-of-pearl staff.

2223-ANTIQUE JAPANESE HALBERD

Blade ornamented with a carved dragon. Black and red lacquer staff.

2224-ANTIQUE JAPANESE LANCE

Carved blade with blood channel. Mother-of-pearl and lacquered staff.

2225-ANTIQUE JAPANESE WAR LANCE

Three-cornered blade, with blood channel and carved serpent. Staff incrusted with mother-of-pearl.

2226-ANTIQUE JAPANESE WAR SPEAR

Three-cornered carved blade. Staff incrusted with mother-of-pearl. 
Three-cornered carved blade. Red and black lacquer staff.

2228-TWO ANTIQUE JAPANESE WAR LANCES

Carved blades. Long red and black lacquer staffs.

2229-JAPANESE MATCH-LOCK GUN

Massive octagonal barrel, decorated with the Tycoon's crests, in gold lacquer and inlay. Brass mountings. Seventeenth century. Length, 42 inches.

\section{0-JAPANESE KRIS}

Wave edge blade of curious luminated steel. Short crook handle. Length, 14 inches.

2281-BUDDHISTIC “PHUR-BU," OR CEREMONIAL DAGGER

Wide leaf-shaped blade. Supported between two dragon heads, pierced with holes for yak tail ornaments. Metal shows traces of original black lacquer. Shaft of red lacquer. Carved with emblematic demons; plaited green silk cord attached. Antique. Length, 231/2 inches.

2232-DAIMIO SWORD CASE

Elaborately incrusted with mother-of-pearl.

2233-LONG SWORD

Blade signed Karé-mitsu; date, 1358 A.D. Hilt, guard and scabbard of carved wood. Subject: dragons chasing the sacred ball in the clouds. The dragons are applied to wood surface and are carved of ivory, tortoise-shell and mother-of-pearl. Two crystal balls also inserted. A very fine specimen of modern decorative carving.

\section{4-DAIMIO DRESS SWORD}

Long straight blade. Inscribed, "Made with ground metal found at Kuwana City, province of Omi." Double-handed hilt of sharkskin wound with silk cord. Gilt bronze guard ornamented with sunken panels, characters and emblems chased in relief. Scabbard of gilt leather wound with cord to match hilt. Hilt tip of gold, repoussé dragon and clouds. Menuki large gilt dragons. Kojiri gilt crayfish with long extended spines. 
Fine antique blade. By Suké-sada. Signed, "Bishiū Osafuné jūnin Yokoyama Kōzuké daijō Fujiwara Suké-sada." Dated, 1520-1557 A.D. Hilt of shark-skin wound with silk; bronze guard; bean vine and insects in shakudo, copper and gold. Scabbard of brown lacquer: storm cloud effects. Hilt tip ornaments, Kajiri, also Kogai and Kodzuka, of Shakudo. Insects, snails, etc., in gold and copper.

2236-LONG SWORD

Blade by Suké-sada. Dated, 1520-1557 A.D. Same as No. 2235 and companion blade.

\section{7-SHORT SWORD}

Fine antique blade. Dragon grasping the sacred spear carved on one side. Two grooves on the other. Hilt and scabbard a light brown mottled lacquer over which there is a grape vine of black lacquer and malachite. Ornaments of gourds and insects in silver, shakudo, gold and mother-of-pearl applied in relief.

\section{8-DAGGER}

Heavy narrow blade. Signed, "Getsuzan Yoshi-mitsu." Date, about 1373 A.D. Hilt wound with brown silk cord. Mountings of iron, skakudo, gold and bronze, representing the zodiacal animals in relief. Sheath of red lacquer to imitate bark of a tree. Kodzuka of iron, file surface set with small compass; inscription on knife blade.

\section{9-D AGGER}

Short blade, with mystic characters carved in the steel. Hilt and sheath of wood; mountings of white bronze, engraved with vines. Kogai same motif.

\section{0-SHORT SWORD}

Plain straight blade. Made by Nobu-shigé, at the castle of Furukawa of Soshiū; dated, 1866. Hilt, shark-skin tape wound; small iron guard, gilt dragon ornament. Kashira and kojiri of iron, with cranes in shakudo and gold. Black lacquer sheath, leather surface. Iron kodzuka, clouds and lightning. 


\section{1-DAGGER}

Heavy, short blade. Signed, Kuni-sada; date about 1503, A.D. Hilt and sheath of black lacquer in imitation of rough grain wood; polished lacquer tips. Kodzuka of bronze: crayfish in relief.

\section{2-DAGGER}

Short plain blade. Hilt of wood. Menuki. Musical instruments. Hilt tip and ornaments of shakudo and copper, with gold insects and vines. Sheath of black lacquer.

\section{3-DAGGER}

Small straight blade. Signed, "Yetchū no Kami Fujiwara Kanékuni." Dated, "Teikiō period, 1683." Hilt and upper part of sheath of fine texture; polished shark-skin. Menuki, gilt coiled dragons. Kashira joint and kojiri of iron; oak leaves and tortoise in gold. Black lacquer sheath with vine in gold. Kogai and kodzuka gilt metal; turtle and stork.

\section{4-DAGGER}

Double edge blade, with large spear carved in one side; two smaller ones on the other, filled in with red lacquer. Signed, "Kane-masa," about 1466 A.D. Sheath and hilt of wood on which are reptiles and insects wrought in free relief in silver, gold, copper and shakudo.

\section{5-SHORT SWORD}

Heavy blade, with one deep and two shallow grooves on sides. Hilt of shark-skin wound with silk cord. Scabbard of dark lacquer, imitation of leather. Hilt tip and ornaments, bronze, shakudo and gold. Men in boats fishing. Kodzuka, shakudo and gold, a fish chasing two eels. Knife blade inscribed.

\section{6-DAIMIO DRESS SWORD}

Long curved blade. Hilt of shark-skin decorated with crests and cocoons; gilt bronze hilt with loop guillons; ornaments of bronze

gilt, engraved in scroll ornament. Sheath of aventurine lacquer, with crests in gold lacquer.

\section{7-CHINESE MANDARIN DRESS SWORD}

Long, thin, rapier-shaped blade. Hilt and scabbard of white bronze, engraved with dragon in clouds. The hilt is pagoda shape. 
Long narrow blade. Signed, "Bishū Osafune Tsuné-iyé." Date about 1540 A.D. Carved wood hilt, a manatel or sea-cow head at tip. Small ivory guard. Club-shaped scabbard of wood, corrugated surface. Bronze dragon ornaments.

\section{9-LONG SWORD (COMPANION)}

Fine antique plain blade. Hilt of black leather, carved to resemble cord; band of chased silver; storm clouds with Menuki. Cut end of a nine-strand cable in gold. Hilt tip and joint chased silver; storm cloud. Guard, gold rim inlaid on both sides. Scabbard of black polished lacquer, cable or corrugated surface. Kojiri to match; hilt tip.

\section{0-SHORT SWORD}

Antique blade, carved, with grooves. Signed, Kané-moto. Date, about 1573 A.D. Leather hilt wound with flat cord. Guard of bronze. Fir tree and gold birds; ornaments of bronze with small gold stars. Scabbard of black lacquer powdered with mother-ofpearl; overlaid with autumnal maple leaves in natural colors. Kodzuka to match scabbard decoration.

\section{1-LONG SWORD}

Plain antique blade. Signed, "Idsumi no Kami Fujiwara Kunitora." Date, about 1367 A.D. Hilt of shark-skin, wound with yellow silk cord. Menuki, white metal tigers. Hilt tip and joint chiselled silver, dragons and clouds. Scabbard of black lacquer, overlaid with mottled cloud in gold lacquer; a silver band with rabbits engraved. Kojiri of silver; pierced and engraved cloud. Kodzuka of brass, flower and inscription. Inscribed knife blade.

\section{2-LONG SWORD}

Antique blade, grooved to tip. Shark-skin hilt wound with silk. Guard of shakudo, with gold dragons in relief. Hilt tip, joint, cord loop, kojiri and slides of shakudo and gold; cloud and dragon ornament. The scabbard of black lacquer, delicately outlined cloud effect in mother-of-pearl dust. Long kogai, shakudo with gold dragon. 
Plain, straight blade. Signed, "Yechizen no Kuni Jū Kanétsuné." Date, about 1503 A.D. Hilt and part of sheath covered with fine texture shark-skin. The balance of sheath of fine mottled red and black lacquer. Kashira and kojiri openwork metal. White metal kodzuka and chop-sticks.

2254-LONG SWORD (COMPANION)

Fine antique blade; deep groove on one side, two narrow grooves on the other. Small square copper guard, two butterflies in gold and shakudo. Hilt, shark-skin, wicker wound. Menuki, copper; heads of grain. Hilt tip and joint, shakudo and gold plants. Scabbard, black lacquer of a wood texture. Kodzuka of copper; basket of clams, gold and shakudo. Inscribed knife blade.

\section{5-DAGGER}

Short plain blade. Sheath and hilt of carved wood. Dragon in the clouds; openwork. The dragon's teeth and claws are of gold and skakudo. The guard and kodzuka handle all carved from same piece, represent sections of bamboo.

\section{6-LONG SWORD}

Plain, heavy blade. Signed, "Hizen no kuri Omi no Kami Fujiwara Tadayoshi." Date, about 1525 A.D. Hilt wound with split bamboo fibre; white metal mountings. Plaited silver guard. Dragons in the sea carved in relief; also has added knuckle guard. Scabbard of brown lacquered wood, carved in cable pattern. Unique.

\section{5\%-LONG SWORD}

Fine antique blade. Signed, "Yasu-tsuné." Date, about 1525 A.D. Hilt of shark-skin, wound with brown silk cord. Guard of shakudo, with aquatic plants in gold. Scabbard of black lacquer, inlaid with small, irregular fragments of malachite. Kashira and ornaments of shakudo, of figures and birds, in silver and gold.

\section{8-SWORD (COMPANION)}

Short plain blade. Signed, "Bizen no Kuni Jū Osafuné Katsumitsu." Date, about 1503 A.D. Hilt of shark-skin, wound with silk cord. An ornamented skakudo guard. Hilt tip, ornaments and kodzuka of shakudo, with vines and flowers touched with gold. Scabbard in longitudinal section of shark-skin filled in with black lacquer and polished, and dark-green sprinkled with brown saffron leaves. 
Japanese mounting. European blade of a naval officer. Seventeenth century. Hilt of bronze in form of a fish. Bronze guard, two coiled sea-serpents. Scabbard of fine texture shark-skin. Plain bronze mountings.

2260-DAGGER

Plain, smooth finish blade. Hilt of dark red wood. Sheath of black lacquer; rain effect.

2261-HARA-KIRI KNIFE

Heavy curved blade, edge on reverse side; the outer side of the blade is dentilated and lacquered in black. Hilt of very fine silk cord. Menuki, rosettes of flowers in gold, silver and shakudo. Mountings are of engraved silver. Sheath of coral red lacquer; corrugated surface. Kodzuko of shakudo, engraved to match. Inscribed knife blade.

2262-DAGGER

Very old blade, showing odd markings in the steel. Hilt wound with silk cord; mounting of bronze and gilt. Sheath of dark green lacquer, imitation of leather. Kodzuka, two rabbits chasing the moon.

\section{3-DOCTOR'S SWORD}

Sword shape; wood; natural fibre. (No blade.) Polished buckhorn tips and band, on which is carved a frog. Small ivory letters and other ornaments applied in relief to surface.

2264-SWORD

Fine curved blade, with groove. Shark-skin hilt silk wound. Guard of shakudo, with daisies in gold. Hilt tip and mountings of silver and shakudo. Scabbard lacquer to imitate leather. Kogai of shakudo; flight of geese.

2265-SHORT SWORD

Fine blade, carved with a demon on one side; two grooves on the other. Signed, "Chōsoné Kori niūdō Ko-tetsu. Hilt, shark-skin, wound with silk cord. Menuki, Hōwō bird, shakudo and gold. Guard hilt, tip, joint and kojiri, shakudo, damascened in gold. Scabbard of very dark green lacquer, with minute spots of powdered shell. Kodzuka, shakudo and gold. Geese and aquatic plants. Inscribed knife blade. 
Fine blade; spear and small grooves carved near hilt. Signed, "Kawabé Gihachiro Masa-hidé, seal." Date, about 1400 A.D. Hilt and sheath of wood carved to represent worm-eaten surface, with ornaments of Hōwō birds in shakudo and gold. Hilt tip, joint, kojiri and kodzuka of silver; chiselled cloud design with flying birds in gold.

\section{7-LONG SWORD}

Wide, heavy blade; carved steel war god on one side; inscription on the other. Signed, Minamoto-Masayuki. Date, about 1550 A.D. Handle of chiselled bronze: dragon in the clouds. Basketshape guard, openwork design. Scabbard lacquered to represent red leather. Kojiri of bronze, clouds outlined in gold. Kodzuka and kogai of iron, with gold cloud effect.

\section{8-DAGGER}

Small plain blade. Red-stained ivory hilt, carved. Fish and waves. Other ornaments of ivory-stained ochre on the hilt tip and octopus and fish. Cord loop a crab. Sheath of plain ivory, with inscription. Ivory kodzuka; engraved fish and inscription.

\section{9-LONG SWORD}

Heavy antique blade, with bevelled back. Signed, "Sunshū Jū Mori-toshi." About 1361 A.D. Shark-skin hilt wound with leather. Menuki of gold. Dog Foo. Silver guard chased with storm clouds, showing head and tail of a dragon in gold. Hilt tip, joint and kojiri of chased silver; chrysanthemums and leaves. Scabbard of black lacquer, decorated with maple leaves in autumnal tints.

\section{0-SHORT SWORD}

Fine antique blade, double grooves in each side. Signed, "YasuMitsu." Date, 1520 A.D. Hilt, shark-skin silk wound. Menuki, female figures, gold and shakudo. Koshira, a hound in relief. Guard of bronze, water rat and aquatic plants. Sheath of wood, lacquered to imitate bamboo, overlaid by a vine and insects in gold lacquer. Silver kodzuka; waves and sea birds in gold. Inscribed knife blade. 
Double edge blade, grooved on both sides. Signed, "Banshū Akashi jū Kané-toku." Dated 181\%. Hilt and sheath of dark red lacquer and metal finish to represent a fire-lock pistol. Mountings of brass. The hammer locks the hilt to scabbard.

\section{7\%-LONG SWORD}

Superior blade, carved with God of War and mystic characters. Signed, "Omi daijō Fujiwara Tada-hiro." Date, about 1500 A.D. Hilt wound with black wicker; wide chased silver band in centre, with two medallions, "Men in a Boat" and Hōwō bird, in silver, gold and shakudo. Hilt tip, joint and kojiri silver; waves, figures in shakudo, and small bits of red coral inserted. Silver guard, with gold rim; subject, a stormy sea, with figure of a man, in shakudo, drawing a net. Scabbard: black polished lacquer, with waves in roughened outline. Kodzuka, silver, chased to match mountings.

\section{3-SHORT SWORD}

Fine heavy blade, bevelled back. Signed, "Kiyo-hisa tsukuru." About 1470 A.D. Shark-skin hilt, cord wound. Openwork silver guard: fish and waves. Hilt tip and ornaments of silver and gold; waves and fish. Sheath of black lacquer, powdered with mother-ofpearl dust. Kodzuka and chop-sticks of iron gold ornament.

\section{4-SHORT SWORD}

Fine blade, double grooves of both sides. Signed, "Sada-Yoshi." Date, about 1591 A.D. Hilt of shark-skin, silk cord wound. Small plain silver guard. Scabbard of brown lacquer, outlined in red to imitate bark. Hilt tip, joint and kojiri of engraved silver. Engraved silver chop sticks. Kodzuka: fish and wave in relief. Brass knife blade.

\section{5-DAGGER}

Superb blade, carved with a dragon clutching the sacred ball; two lines and a character on the other side. Signed, "Awataguchi Omi-no-Kami Tada-tsuné." Date, about 1500 A.D. Hilt and sheath of engraved silver; subject, clouds and birds. Kasahira and kojiri, also guard mounts, chased silver with gold birds. Kogai and kodzuka of silver, same design. Inscribed knife blade. 
Blade by Masafusa of Satsuma. Date, about 1400. Signed, Sasshu Fijiwara Masafusa. Hilt and scabbard covered with leather. Mountings of iron and skakudo, representing the dragon chasing the sacred pearl among the clouds. Guard of iron and gold; cloud effect. Iron chop sticks inlaid with gold chrysanthemums.

\section{7-SHORT SWORD}

Antique blade, deep groove; squared tip. Lacquer hilt overlaid with pierced metal vines. Hilt tip, joint, ornaments and kojira of gilt metal. Engraved with birds and flowers. Small square bronze guard. Scabbard, of black lacquer, overlaid by vines and landscape in gold lacquer. Kojiri inlaid engraved ivory panel filled in with red. Knife blade engraved with characters and Mikado crest.

\section{8-SHORT SWORD}

Fine heavy blade, deeply grooved on each side. Shark-skin hilt. Menuki. Shakudo tigers with gold stripes. Kashira joint and cord ring of carved jet; without guard. Scabbard; sides of gold lacquer. Subject, dragon in the clouds, framed in black, powdered with pearl shell dust. Silver kogai and kodzuka engraved.

\section{9-SHORT SWORD}

Short heavy antique blade, deeply grooved on each side. Signed, "Kané-nori." Date, about 1579 A.D. Hilt and scabbard of black lacquer, powdered with mother-of-pearl. Silver guard with bamboo rim. Mountings of silver; chased storm clouds and gold dragon. A band on hilt contains raised panels of pine cones. Silver kodzuka.

\section{0-DAGGER}

Wide blade, in which is carved an openwork dragon grasping the sacred spear. Hilt wound with wicker. Silver mounts chased in wave design and inlaid with gold dots. Menuki: dragon in the clouds. Mirror black lacquer sheath.

\section{1-DAGGER}

Fine steel blade. Signed, Kané-sada. Date, about 1503 A.D. Shark-skin handle. Menuki of carved gold; silver mountings. Scabbard, aventurine lacquer with black lines; silver dragon-fly near end. Chop-sticks and kodzuka silver; applied flowers in gold. 
Antique blade, deep groove on each side. Made by Nori-Mitsu of Osafuné, Bizen, dated 14\%. Hilt, shark-skin, cord wound. Scabbard lacquered in imitation of a section of bamboo. Silver mountings finely chased; leaves and poppy flowers applied in gold. Kogai and kodzuka same design.

\section{3-SHORT SWORD}

Heavy straight blade. Signed, "Inaba no Kami Fujiwara Kanétatsu." Dated 1630. Hilt of dark green shark-skin; fine texture. Silver guard and ornaments carved in high relief; storm clouds. Sheath of black lacquer, corrugated surface. Silver chop-sticks and kodzuka; cloud decoration. Inscription on knife blade.

\section{4-DAGGER}

Straight blade. Bevelled back. Hilt wound with cord. Mountings of finely chiselled brass; flowers and leaves. Lacquer sheath; alternating bands of red in two shades. Kogai and kodzuka to match mountings.

\section{5-LONG SWORD}

Handsome blade, grooved on böth sides. Signed, Kore-suké. Date, about 1373. Hilt of shark-skin. Bronze guard pierced with heartshape openings; gold oak leaves applied. Scabbard of aventurine lacquer, with oak leaves and Tycoon's crests in gold. Menuki, gilt bronze Hōwō birds. Hilt tip, joint, cord rings and other metal parts of bronze engraved and gilt.

\section{6-LONG SWORD}

Superior antique blade. Signed, Hokuyen Numakuni tsukuru. Hilt of shark-skin, silk wound. Guard of chiselled shakudo; flowers and leaves with small panels of figures and inscriptions in gold. Scabbard of mottled red and gold lacquer, with a wide band of black lacquer at top. Hilt tip, joint ornaments and kodzuka of chiselled gold. Subject, "Sunrise at Sea." Kojiri of iron, imitation of leather; gold mark and coiled dragon. 
Short heavy blade, groove in each side. Hilt and scabbard of leather, with medallions of copper and gold lacquer applied to surface. Hilt tip, menuki, joint, guard and ornaments finely carved shakudo, inlaid with gold. Two small inscribed panels also on hilt; a line of small silver tablets outlined in gold, alternating with gold head nails, to cover seam in leather, from hilt to tip. Kogai and kodzuka of shakudo and gold; pansies.

\section{8-MINIATURE DAGGER}

Fine small blade, grooved. Signed, "Yasu-mitsu." Date, about 1520 A.D. Hilt and scabbard of silver engraved with chrysanthemums and poppies inlaid with gold.

2289-MINIATURE LONG SWORD

Delicate steel blade. Signed, "Kané-nao." Date, about 1527 A.D. Iron hilt and scabbard, treated to imitate leather; gold crests applied to surface. The mountings are of engraved silver; conventional flowers.

\section{0-SHORT SWORD}

Fine blade, dragon and vine carved in surface. Signed, "Hizen no Kuni Jūnin Tada-yoshi." Date, about 1525 A.D. Hilt of kiriwood. Guard and mountings of chiselled silver representing the "Sacred Grove"; small jewelling inserted to represent fruit. Black lacquer scabbard, imitation of leather. Kodzuka engraved in outline. Extra fine knife, carved and inscribed.

\section{1-DAGGER}

In lacquer sheath to resemble a closed fan.

\section{2-SHORT SWORD}

Heavy blade; short grooves on each side. Signed, "Fujiwara Sada-yuki." Date, about 1520 A.D. Hilt and scabbard of wood carved in waves; fish applied in relief, of ivory and mother-ofpearl. Small guard of carved wood. 
Fine plain blade. Made by Yeijō and Kane-michi. Signed, Dai Hoshi Hōkiō Rai Yei-jo Fujiwara, Rai Kane-michi. Dated 1692. Hilt of stamped and painted leather. Bronze menuki; four claw dragons. Guard and metal mountings all to match of yellow chiselled bronze; poppy plant. Scabbard: black lacquer to imitate a rough grain leather.

\section{4-LONG SWORD}

Fine blade. Signed, Koré-mitsu. Date, about 1373 A.D. Twohand hilt of shark-skin, silk wound. Guard of finely chiselled silver openwork of two crayfish. Silver and shakudo hilt tip and ornaments of crayfish. Green lacquer scabbard with small clam-shell inlaid.

\section{5-SHORT SWORD}

Wide, handsome plain blade. Signed, "Kuni-hiro." Dated $15 \% 6$ A.D. Hilt of shark-skin wound with wicker. Silver guard, chased vines and gold flowers. Menuki, bronze gourds. Hilt tip, ornaments and kojiri chased silver, flowers, birds and insects. Scabbard of black lacquer, with vines in gold lacquer and mother-ofpearl. Kogai and kodzuka to match mountings.

\section{6-SHORT SWORD}

Fine blade, grooved on both sides. Shark-skin hilt. Menuki of antique warriors. Iron guard, representing a temple bell. Scabbard lacquered to represent tree bark powdered with mother-ofpearl. Kodzuka and kogai: Gods of Good Luck in bronze and gold.

\section{7-DAGGER}

Heavy short blade. Hilt of shakudo; insects and cones in relief. Kashira and kojiri of shakudo: gold flies in relief. Sheath lacquered to imitate bark, with glow-worm and centipede in copper, shakudo and gold. Kogai of shakudo, with insect. 
Double-edge blade, finely wrought. Signed, " Shigé." Dated, Meiji, 1869. Hilt of silver, decorated with panels of flowers in gold, silvẹr, shakudo and bronze. Sheath, black lacquer, similar decoration; panels let into surface. The kojiri of silver extends up the side. Kogai and kodzuka; similar decoration.

2299-SHORT SWORD

Plain antique blade. Signed, "Mutsu no Kami Omichi." Dated, Tensho, 1583. Shark-skin hilt, white silk wound. Small guard of shakudo, damascened in gold; Greek conventional line motif. Hilt tip, joint, kodzuka and ornaments of skakudo, with finely wrought gold dragons in relief. Scabbard lacquered to imitate dark green leather. Kojiri, chiselled shakudo and gold. Dragon in the clouds.

\section{0-SHORT SWORD}

Antique blade, carved with sacred spear, mystic character and grooves. Made and signed in full, Riūzōshi Yoshi-tatsu. Dated 1840. Hilt of engraved and chased silver clouds. Menuki dragons of gold and shakudo. Very small guard, silver and gold. Hilt tip, a mountain in clouds, silver, gold inlaid. Sheath of polished black lacquer. Side bands, engraved silver. Kojiri, chased silver, chased with gold dragon. Chop-sticks and kodzuka of silver; same design.

\section{1-DAGGER}

Fine narrow blade, grooved on both sides. Silver hilt, chiselled in high relief, bird of paradise and dragon in clouds. Black lacquer scabbard; clouded sky effect; mounts of chased silver. Kojiri of silver carved to match hilt; bird of paradise in clouds. Kodjuka, silver with gold tortoise.

\section{2-SHORT SWORD}

Wide short blade; carved figure in blade. Signed, Chikuzen Dai Jō Dai Kei Nawo-tane. Dated, 1831. Hilt wound with whalebone. Silver guard, with leaves and flowers in shakudo and bronze. Kashiri, kojiri and ornaments of silver and shakudo; cocks and Hōwō birds, finely chiselled. Sheath of black lacquer, ornamented with die sunk leaves in surface. Kodzuka and chop-sticks of white metal. 
Fine blade, grooved on both sides. Signed, "Hiro-suké." Date, about 1500 A.D. Hilt and sheath of silver, chased in cloud effect and applied gold dragons. Ornaments of silver, shakudo and gold. Dragons chasing the Sacred Pearl. Kogai and kodzuka of shakudo and gold; cloud design and coiled dragons.

\section{4-HARA-KIRI KNIFE}

Short blade; edge on reverse side; inscription engraved on the blade. "Tamba no Kami Yoshi-michi tsukuru," or made by Yoshi-michi with foreign metal. Hilt and scabbard lacquer in close imitation of wood. Figure and tree in gold and black lacquer on scabbard. Tips of ivory-stained green. Cord loop, a finely executed mask in ivory (old man with long beard). Menuki, bronze tiger and cloud. Kodzuka, iron damascened in gold.

2305-SHORT SWORD

Small light blade. Hilt and sheath of wood, carved to represent a sea monster sporting in the waves. Silver guard. The cord loop represents the Sacred Pearl. The joints of red copper; surface of leather texture.

\section{6-DAGGER}

Thick, narrow blade, running to a sharp point, inscribed with emblematic characters. Signed, "Ki Masa-yoshi tsu-tsushinde tsukuru." Dated 1826. Hilt of black lacquer to imitate cord winding. Menuki, full-blown roses in gold and silver. Kashira, kojiri, joint, chop-sticks and kodzuka chased silver; subject, waves, with sea-birds in gold. Sheath in two colors; lacquer in narrow bands, polished red and dark brown; rough surface.

\section{0\%-DAGGER}

Narrow antique blade. Shark-skin, silk-wound hilt; cock and hen in gold. Menuki, hilt tip and joint, silver and gold leaves. Sheath of black lacquer powdered with mother-of-pearl, inlaid with poppy flowers in gold lacquer. Kojiri a butterfly, gold body, silver wings. Kojiri, shakudo; Dog Foo in relief. 
Fine blade, bevelled and grooved. Signed, Hitachi no Kami Fujiwara Uji-fusa." Date, about 1573 A.D. Hilt of silver; raised ornament of flowers and frogs in silver shakudo and gold. Hilt tip, three warriors; joint a landscape. Black lacquer sheath. Silver inlay kojiri. Engraved kodzuka. Inscribed knife.

\section{9-DAGGER}

Short double-edged blade. Hilt and sheath of carved ivory. Mythological subject: Wise Men in the Sacred Grove, with dragon in the clouds, its body appearing on the kodzuka, and the head showing through the clouds on both sides of the hilt. The tips are water lilies and leaves.

\section{0-HARA-KIRI KNIFE}

Short, rough blade of great age. Edge on inside of curve; handle of wood; in centre a small band of antique leather, outlined with twisted silver wire and two small bronze buttons. Tip of horn. Wood sheath, covered with bark; horn tips (fragment of bark missing). Bronze kodzuka engraved with poppy plant.

\section{1-DAGGER}

Short, heavy, triangular blade, with groove on flat side filled in with red. Hilt and sheath are of wood, club shape, with gold lacquer clouds, through which appears an elaborately carved bronze dragon. Hilt ornaments, gold dragons and Hōwō birds. Connecting hilt and sheath is a fine silk cord, on which are two slides, in gold and shakudo, in form of reed musical instrument and cricket cage. A very remarkable antique weapon.

\section{2-DAGGER}

Fine blade, carved with dragon grasping the sacred spear. Signed, Shigé-toshi. Dated 1871. Hilt of black lacquer, imitation of cord; a band of chased silver in centre; storm waves. Hilt tip, joint and kojiri, chased silver waves and flying sea-birds in gold. Sheath, black lacquer; giant wave outlines in gold. Silver kogai and kodzuka, same motif. 
Fine, heavy antique blade. Signed, "Chō-unsai Moto-toshi."

Dated, 1860. Hilt of coarse grain leather; the mountings are of silver, engraved in scroll pattern. Scabbard of black lacquer, covered with small rings in relief. Silver kogai and kodzuka engraved to match. Inscription on knife blade.

\section{4-DAGGER}

Short narrow blade; dragon carved on one side, the other deeply grooved. Signed, "Tamba Mori-Yoshi." Date, about 1490 A.D. Hilt and sheath of mulberry wood; mountings in fine gold. Floral ornament chased in high relief. Most exquisite workmanship. Kodzuka to match. The knife blade has inscription in very small gold characters.

\section{5-LONG SWORD}

Heavy antique blade. Hilt of shark-skin wound with silk cord. Guard, shakudo; waves and fish carved in relief. Hilt tip and ornaments, shakudo, outlined in gold. Scabbard, black lacquer powdered with mother-of-pearl dust.

\section{6-SHORT SWORD}

Superior blade, flat on one side; the other bevelled and grooved. Signed, "Kadsusa no Kami Muné-michi." Date, about $13 \% 0$ A.D. Shark-skin, wound with silk cord. Scabbard, dark green lacquer, imitation of rough leather. Mountings, guard, kojiri and kodzuka of shakudo, with applied gold flowers and leaves.

\section{7—D AGGER}

Heavy blade, deeply grooved and bevelled; double-edged at point. Hilt wound with fine silk cord. Menuki, a crest in gold and silver. Mountings of silver, with applied gold ornaments. Sheath of black lacquer; corrugated surface. Small silver kogai.

\section{8-DAGGER}

Superior short blade. Hilt of polished shark-skin. Ornaments of silver, conventional rain effect. Sheath of black lacquer, with a polished scroll design on a rough surface. 
Odd-shaped blade. Hilt of ivory; carved fish and wave motif. A guard of silver inscribed in raised letters: I. SHILLING 1726. Sheath of wicker-work, in which there are small European colored beads; a section of green leather (apparently from a European book cover); the tip being of wrought silver. Curious relic of the time of "The Dutch Traders."

\section{0-SHORT SWORD}

Short heavy blade, grooved and bevelled on each side. Signed, "Naga-toshi." Date, 1360. Hilt wound with leather. Scabbard, tortoise-shell lacquer. Hilt tip, guard, ornaments and kojiri chiselled silver wave patterns; also the chop-sticks and kodzuka.

2321-SAKE BOTTLE

In form of a dagger, the hilt or stopper being of carved and inlaid green jade, originally the hilt of a Hindoo sabre. The bottle is of silver in form of a sheath. Engraved inscription covers most of the surface at lower end. Two flying bats in relief. Jade cord ring attached. Bamboo fork in place of kogai.

\section{2-SHORT SWORD}

Triangular blade. Signed, "Jinzûdō Kané-toshi." Date, about 1344. Basket-shaped guard of iron; gold and shakudo dragon in cloud in relief. Shark-skin hilt, wound with cord. Mountings of white metal. Menuki, gilt dragon. Sheath of antique painted leather; a coiled snake in white metal near end. Kogai of shakudo; crayfish and gold leaves in relief.

\section{3-CHOP-STICKS AND KNIFE}

Knife of fine steel; handle of green-stained ivory. Silver mounted. Chop-sticks of engraved ivory; silver tips. Sheath in three compartments, with silver end; centre of engraved ivory for knife and outer for chop-sticks of tortoise-shell. Signed, "Tsuné-yasu." Date, about 1373.

\section{3\%4-DAGGER}

Plain antique blade. Hilt on sheath of Imari (blue and white) porcelain. Hilt in imitation of a cord winding. Sheath decorated with a dragon in the clouds. Period, early nineteenth century. 
Fine blade. Signed, Kawai Hisa-taka. Date, about 1550 A.D. Ornaments of silver chased in wave design. Scabbard, aventurine lacquer, covered with cloud outlines in black. Silver chop-sticks and kodzuka same design.

\section{6-SHORT SWORD}

Handsome mottled blade. By Takahira. Signed, "Yetchū no Kami Fujiwara Takahira." Date, about 960 A.D. Mountings of gilt metal, chased with scroll and floral patterns. Sheath of coralred lacquer. Corrugated surface. Chop-sticks and kodzuka, gilt metal chased in cloud effect. Dragon carved on knife blade; also inscription.

232\%-D AGGER

Fine blade, carved groove on each side. Signed, Fuyu-hiro. Date, about $153 \%$ A.D. Hilt and scabbard lacquered in dark green with minute spots of gold; wave effect. Hilt tip and ornaments, finely modelled crayfish in bronze. Kojiri, the same marine animal in silver, with very long antenna.

\section{8-SWORD}

Curved blade. Signed, Muné-tsugu. Date, about 1373 A.D. Shark-skin, silk-wound hilt. Menuki, birds on branches. Guard, silver, gold inlaid, arabesque design. Scabbard, cherry wood. Elaborate chased silver mount applied to wood. Two ornaments: children at play, and fisherman with basket. Bronze kodzuka; inscription on knife blade.

\section{9-DAGGER}

Narrow, thick blade, with bevelled back, carved with spear and deep groove. Lacquer hilt to resemble cord. Silver mountings engraved in cloud design, with flying geese in relief. Sheath of dark green lacquer, leather texture.

\section{0-DAGGER}

Short, massive blade. Carved on one side with a winged dragon; on the other a wave effect. Hilt of shark-skin filled in with lacquer. Black lacquer guard. Sheath of black and red lacquer to represent a bamboo root. A rare type of ceremonial weapon. 
Thin, narrow blade grooved on both sides. Signed, "Ama-kuni."

Date, about $\% 00$ A.D. Hilt and sheath of shakudo and gold, ornamented with flowers and vines in relief. Menuki, two coiled gold dragons on an engraved band of same metal.

\section{2-DAGGER}

Fine, but unsigned, antique blade. Hilt wound with whalebone. Silver mountings beautifully wrought; cloud effect. Scabbard of leather, with large silver crayfish of superior workmanship. Silver kogai.

From the Brayton Ives Collection, Catalogue No. 371.

\section{3-DAGGER}

Short blade, carved with a spear, deep groove and mystic character. Signed, "Naga-yoshi." Dated 1361 A.D. Hilt and sheath of polished black lacquer carved in bamboo design. Mountings are of oxidized hammered silver with flowers in gold and silver applied in relief.

\section{4-DAGGER}

Small fine blade. Signed, "Kané-yoshi." Date, about 1400-1468 A.D. Hilt and sheath lacquered to resemble a section of bamboo. Hilt tip and joints, silver, bamboo design. Menuki, bronze fireflies. Around the sheath is coiled a silver serpent.

\section{5-DAGGER}

Superior blade. Signed, "Sagami no Kuni bito Minamoto Hisayoshi." Dated 1550 A.D. Engraving by Yoshi-yuki, and dated 1866. Dragon carved on one side; character and emblem on the other. Hilt wound with silk cord. Menuki, gold dragons. Sheath of black lacquer. Silver mountings chiselled and engraved; dragon in clouds. Kodzuka same design.

\section{6-DAGGER}

Small bright steel blade. Hilt and sheath, gilt bronze, decorated with female figure standing on a toad, flying birds and crest in relief. 
Double-edged blade. Carved with dragons chasing the sacred ball, on both sides. Silver hilt, engraved in cloud effect. Scabbard of brown lacquer. Scroll clouds in lighter color; chiselled silver dragon on surface. Made by the artist Yasunabu. Date, 1780.

From the Brayton Ires Collection, Catalogue No. 350.

\section{8-DAGGER}

Short blade, with bevelled back. Hilt and sheath of black lacquer, powdered with mother-of-pearl dust; silver daisies inlaid. Mountings of silver; conventional rain effect. Menuki, silver butterflies.

\section{9-DAGGER}

Small, bright steel blade. Hilt and sheath of gilt bronze. Applied in relief is a figure of a boy, birds, bats and crests in silver and gilt metal.

\section{0-DAGGER}

Heavy blade, double-edge at point. Made by Fujiwara Mato-michi. Date, 1820. Sheath, coral, and black lacquer, with fine pearl dust, inlaid with water-lilies in silver. Ebony hilt. Silver mountings, engraved with crest of kiri. Silver kogai and kodzuka.

\section{1-H $\bar{O} C H \bar{O}$ KNIFE}

Massive short blade, 33/4 inches wide. Made by Muné-tsugu; date, 1373. Signed, "Kozan Sobei Muné-tsugu; engraved by Toriūsai Kiyotoshi." Inscriptions on the reverse meaning "a work of Masa-muné, one of the treasures kept in the temple Tenmangu, in province of Sagami. A dedication piece from Nomura ToshiKatsu, presented on the 11th year of Tempo, 2nd month (1840)." The black lacquer scabbard bears inscriptions in gold lacquer writing, "Masa-muné hōchō utsushi." Carved with Buddhistic characters on one side; a plum tree on the other. Black lacquer hilt and scabbard, decorated with a coiled dragon, and Chinese characters in gold lacquer.

From the Brayton Ives Colnection, Catalogue No. 363. 
Superior blade. By Masa-tsuné in Nagaya. Date, about 1593 A.D. Hilt of shark-skin, wicker-wound. Menuki, exquisitely carved flowers in shakudo, copper and gold. Hilt tip and joint, chased silver; butterflies and leaves. The sheath, of gold lacquer, is partly covered by an openwork silver plate, the openwork filled with gold flecked black lacquer. Silver kodzuka, chased with leaves.

\section{3-TEMPLE SWORD}

Double-edged blade. Made by Hiro-taka. Signed, "Shingen Yechizen daijo Hiro-taka korewo horu," at the age of sixty years, 1838. Carved with dragon and floating clouds on each side by Omakumi. The hilt beautifully chiselled bronze in form of the sacred spear. Scabbard of black lacquer; carved dragon coiling about its entire length, partly filled in with red lacquer.

\section{4-DAGGER}

Blade by Kiyo-mitsu of Osafuné. Chiselled on one side is a Buddhist priest in official robe; on the other an antique standard. Signed, Bizen no Kuni jū Osafuné Kiyo-mitsu tsukuru. Dated, 1520. Sheath and hilt of silver finished in leather effect, on which are raised in high relief the zodiacal animals in gold shakudo and shibuichi. Boar, bull, cock, dog, goat, horse, monkey, mouse, rabbit, snake and tiger and the large, three-toed dragon on sheath, engraved. Kodzuka to match.

\section{5-TEMPLE SWORD}

Straight two-edged blade. Signed, "Ama-kuni." Date, about $\mathbf{7 0 0}$ A.D. Original carved iron mountings. The kojiri, a demon face. Modern hilt of chiselled bronze. Scabbard black lacquer powdered with gold, and a three-claw dragon winding around the scabbard.

\section{6-LONG SWORD}

Fine blade. Carved with stork and tree on one side; tortoise on the other, by Kanematzu. Signed, Bizen, Osafuné Yasu-mitsu. Dated 1520. Punch holes made later by Goto Shintaro, in 1851. Shark-skin hilt wound with white silk. Hilt tip, ornaments and joint represent fish in silver, shakudo and gold. Silver guard, carved octopus, studded with gold dots. Sheath, sea-green lacquer, carved in wave effect and fish filled in with red lacquer. Kojiri, large silver crayfish, with long extended antenna. 
Beautiful antique blade. Signed, "Chōsoné Kori niūdō Kötetsu." Carved; on one side a dragon grasping the sacred sceptre, and on the other an emblematic character. Guard of shakudo, with the animals of the zodiac in gold, by Gotou. Hilt and scabbard of bronze lacquer, alternate rough and smooth surface to represent clouds. Silver bands on sides of hilt in cloud effect. Hilt tip, kojiri and ornaments dragons in gold and silver, chased in high relief.

\section{8-DRESS SWORD}

Antique blade, carved with sacred sceptre and grooves. Signed, Omidaijō Fujiwara Aki-hiro. Date, about $13 \% 3$ A.D. The hilt, guard, scabbard and cord slides a most elaborate work in cloisonné enamel in brilliant colors. Subject, Hōwo birds and chrysanthemums on a red background. The Tycoon's crest many times repeated; at lower end of scabbard a character in black on each side. Has very heavy silk cord and tassels. A superb piece of modern enamel work.

\section{9-DAIMIO'S LONG SWORD}

Sabre-shaped blade. Signed, Bishiū Osafuné Kane-mitsu. Dated, 3d year of Yenbun, 8th month. Hilt of shark-skin. The end is a chiselled silver Hōwō bird in full flight. Menuki, are gold oakleaf crests. The guard of odd shape with projecting quillons of engraved and gilt silver. Scabbard, black gold-dotted lacquer. Four engraved ornamental plates cover most of the surface, also gold oak-leaf decoration. The two cord loops have high projections of silver gilt to which are attached the belt cords.

\section{0-LONG SWORD}

Fine blade, with sacred spear carved in groove. Signed, "Sukemitsu." Date, about 1531 A.D. Hilt of shark-skin wound with leather. Guard and mountings of gilt bronze, decorated with enamel. Vine motif. Scabbard of alternating small bands of red and black lacquer. 
Superb antique blade, carved with dragon chasing the sacred pearl, and sacred spear. Signed, Utano Kami Tada-motsu. Dated 1782. Ornaments of carved silver, waves and fish, in gold and shakudo. Guard, an openwork dragon in silver of exquisite workmanship. Scabbard, red lacquer, with waves and fish outlined in black. Kojiri, entwined octopus in silver and gold. Kogai and kodzuka, carved silver, waves and fish in gold and shakudo.

\section{2-LONG SWORD}

Fine blade, carved with dragon grasping the sacred spear and mystic characters. Made by Hiro-tsugu, about 1543 A.D. Signed, "Soshī̄ Jū Hiro-tsugu tsukuru." Hilt and scabbard covered with a brown and gold brocade; the tips are of black lacquer imitating leather. Five large flying storks on each side, in shakudo; also toad and small peacocks in same metal. Antique iron guard, two grotesque figures climbing a mountain.

\section{3-DAGGER}

Straight, double-edged blade. Signed, Kadsu. Carved with the God Fudo and Sanskrit characters. Hilt of chiselled shakudo, lined in gold in form of a Konbo. Silver band, chased wave pattern, holds the blade in place. Sheath of bronze, gilt grooves and silver band at top. Around the sheath is coiled an elaborate chiselled silver three-claw dragon, grasping the end in its mouth; the flames and sacred pearl are in gold. A very extraordinary piece of metal-work.

\section{4-DAIMIO DRESS SWORD}

Fine antique blade, grooved on each side from hilt to tip. Signed, "Tsuna-iye tsukuru." Date, about 1541 A.D. Hilt of carved silver to represent a Hōwō bird with beak of gold. Menuki, the family crest in gold. Guard of engraved and chiselled silver, scroll pattern. Scabbard, aventurine lacquer, decorated with Hōwō birds in flight in gold lacquer. Kojiri and slides decorated to match guard. Original silk embroidered leather belt straps. Silver mountings. 
Heavy, antique blade, finely wrought. By Masa-nori of Yamato. Signed. Date, about 1557 A.D. Hilt of shark-skin wound with wicker. Guard of shakudo; tiger and dragon in relief in gold. Menuki, a large silver dragon encircling the hilt. Tip and ornaments of silver and shakudo. Scabbard, black lacquer inlaid with silver crests. Kojiri, silver cloud with gold dragon. Inscribed silver chop-sticks.

\subsection{6-DAGGER}

Very. short wide blade, bevelled back. Signed, "Mori-hidé tsukuru." Date, about 1440 A.D. Sheath and hilt of black lacquer and powdered mother-of-pearl, with operculums in surface. Bronze mounts chased to imitate a fine grain shark-skin; spaces filled in with red lacquer. Kodzuka damascened in gold and silver.

\section{5\%-DAGGER}

Small, narrow blade; bevelled back. Sheath of aventurine lacquer, with dragon flies in brown. Silver mounts. Kashira and kojiri, head of marine tortoise carved in silver.

\section{8-SHORT SWORD}

Blade by Muné-tsugu; carved with a demon on one side, a dragon on the other. Engraving by Sō-Kuan. Signed, Kozan Munétsugu tsukuru. So-Kuan horu; dated 1845. Hilt of mottled pearl lacquer. Menuki, silver snake and toad. Hilt tip, joint and kodzuka and kojiri of wrought silver; leaf and fruit motif, by Sankan of Tokio. Scabbard of black lacquer powdered with gold.

2359-DAGGER

Fine small blade, with bevelled back. Hilt and sheath of black lacquer, powdered with mother-of-pearl. 'Silver mountings. Conventional rain effect, inlaid with silver flowers. Menuki, flower crest in gold.

2360-D.4GGER

Handsome blade, with bevelled back. Hilt and scabbard of black lacquer powdered with mother-of-pearl dust. Silver mountings; conventional rain drops. 
Blade by Yokan. Early eighteenth century. Teakwood hilt, about which is wound a dragon of copper, shakudo and gold; the head running through the guard; from its open mouth projects the blade. Guard of shakudo, carved cloud design. Sheath of dark red lacquer. Kodzuka of shakudo, clouds sustaining the sacred pearl in gold.

2362-PAPER KNIFE

In form of small dagger. Ivory blade, handle and sheath of carved bamboo. Plum tree and magnolia blossoms and branches; the ends are basket pattern tipped with ivory. Metal cord loop; cord of blue leather; ivory button and slide; also an antique coin (cash).

\section{3-DAGGER}

Fine blade. Carved openwork; dragon grasping the sacred spear. Signed, "Shü Manzai Mori-hiro." Date, about 1392 A.D. Shark-skin hilt wound with wicker. Hilt tip carved silver; balloon fish, ornaments silver and bronze octopus and crayfish. Sheath of black lacquer, sprinkled with gold. Kojiri silver crayfish inlaid in the lacquer, extending the entire length of sheath. Kogai, octopus and shell.

\section{JAPANESE ANTIQUE ARMOR}

\section{4-COMPLETE SUIT OF JAPANESE ARMOR}

Skilfully wrought in iron and other metals, brocade and leather. Elaborate helmet of shell design, with rabbit ornament. Iron cuirass with repoussé rabbit and inserted gold. The helmet is by Miyochin Yoshimi, 1604-1656, and the breastplate and shoulderplates are by Miyochin Munesuke, 1665. On the back of the cuirass is a verse reading:

Although as simple as a fair maiden, when before the enemy I became furious and as swift as the hare.

2365-SUIT OF JAPANESE ARMOR

Complete, with an elaborately wrought helmet with gilt Dog Foo ornament. With lay figure. 
2366-COMPLETE SUIT OF JAPANESE ARMOR

Wrought in metals, braids and brocades. With lay figure and spear.

2367-SUIT OF JAPANESE ARMOR

With helmet and war mask complete. Iron, finished with black lacquer, braids and brocades; chain gauntlets and sleeves.

2368-SUIT OF JAPANESE ARMOR

With helmet and war mask complete. Iron, finished with red lacquer, braids and brocades. Chain gauntlets and sleeves.

2369-COMPLETE SUIT OF ANTIQUE JAPANESE ARMOR

Skilfully wrought in iron and fabric. Elaborate iron helmet, with silver ornament of Dog Foo. The iron work is by Miyochin Umestada, 1636-1690; the arm-wear by Miyochin Munetora; the mask by Miyochin Mitsuorao, and the Dog Foo on helmet, which is pure silver, by Yokoya Tomatake, all makers of about the same period.

\section{EUROPEAN ARMS AND ARMOR}

2370-GAUNTLETS

Pair of very handsome finger gauntlets (some fingers missing).

On the cuffs in relief are figures of mounted warriors fighting; the hands show fine tool work. Also a pair of fluted armlets and a gorget. All are much oxidized.

3 pieces, a lot.

2371-GAUNTLETS

Remarkable pair of German (Gothic period) mitten gauntlets.

Flexible hands with fingers outlined; long pointed cuffs. The knuckles are armed with short spikes.

2372-PERSIAN GREAVE, OR ARM GUARD

With chain gauntlet. Similar decoration.

237\%-MINIATURE SUIT OF ARMOR

Wrought in steel. 
German burgonet. Spherical skull-cap with wide neck guard; small peak with movable nose guard and ear flaps. Still retains the original padded lining.

\section{5-HELMET}

German tilting armet. Skull-piece decorated with double groove each side of the high comb; long pointed umbril; the bevor has projecting point on which the umbril rests, leaving wide eye-space, pierced with holes for ventilation.

\section{3\%6-HELMET}

German burgonet. Bright surface skull-cap decorated each side of comb with wide groove. Neck guard riveted on. Hinged earflaps pierced with small holes.

\section{3\% $-H E L M E T$}

German burgonet. High skull-cap with neck guard and umbril riveted on. Hinged ear-flaps, still retaining the original chin straps with metal ornaments.

\section{3\%8-HELMET}

Hungarian dschyckse. Spherical skull-cap decorated with six raised ribs, centre boss and ring for plume. Wide neck guard of four plates, pointed umbril and movable nose guard. Hinged earflaps.

NoтE.-This type of helmet was used in England during the period of the Commonwealth.

\section{9-HELMET}

Similar to the preceding. Still retaining original leather inside.

\section{0-HELMET}

Danish burgonet. Massive spherical skull-cap. Flat neck guard and peak decorated with nail heads around base. Deep bullet dent on side.

This type of war-hat was used at sieges, latter part of seventeenth century.

\section{1-HELMET}

Italian cabasset. Black body, flat narrow rim and small comb. 
Spanish morion. Black body with high comb and wide rim. Socket

for plume riveted to base of the body.

2383-HELMET

German morion. Plain black body; corded comb and rim. Deep bullet dent on side.

\section{4-HELMET}

German morion. Very high comb, 31/2 inches; corded rim; black body decorated with brass rosettes around base.

2385-HELMET

German morion. Black surface corded comb and rim. Border of nàil heads about base riveted to leather rim on inside.

2386- HELMET

German morion of the type worn by the Civic Guard of Munich. Black surface with high comb; on each side a large bright fleurde-lis; around base a row of brass rosettes. Narrow, pointed rim.

238\%-HELMET

Morion. Similar type, with more ornate fleur-de-lis.

2388-PERSIAN ROUND SHIELD

Ornamented with four raised bosses. Chiselled panels. Quotations from Koran outlined with gold damascening.

Diameter, 161/2 inches.

2389-PERSIAN HELMET'

With nose guard and extra fine chain veil. Decoration similar to preceding.

2390-SHIELD

Circular rondache of forged iron. Dome-shaped with boss in form of a spiral shell; the body is ornamented with sunken panels and dots in relief. From type of work probably of Scandinavian origin. Early fifteenth century. 
German ceremonial rondache. Iron repoussé in high relief. Centre boss a Medusa head. The body of the shield a mass of men in antique armor, on foot and mounted, fighting before the walls of a fortified city.

Diameter, 24 inches.

2392-SHIELD

German ceremonial rondache. Slight dome-shaped with spike in boss; finely etched with floriated ornament and panels containing figures of warriors in armor and nobles in court dress; also grotesque heads. Heavy corded rim.

Diameter, 24 inches.

\section{3-SHIELD}

Exquisitely etched ceremonial rondache. Slight dome body raising to a sharp point in centre, the body ornamented with arabesque floriated and dot decoration. Corded edge. The etched surface filled in with niello, and the relief bright polished. Probably Russian early seventeenth century.

Diameter, 24 inches.

\section{4-HURBUK}

Chain mail shirt, with long sleeves. Close mesh of small riveted links; lower edge dentilated to fit over saddle. Weight, 22 pounds.

\section{5-SIAMESE BATTLE SWORD}

Long, wide, curved blade. Handle of wood, with brass mountings. Scabbard of wood, with many brass bands; some of them decorated in a "straw lace" pattern. Very old and curious.

\section{6-SWORD}

Two-handed sword. Massive double-edged blade widening to point measuring at widest part $23 / 4$ inches; blade measures $5 \pm$ inches. Heavy drooping flat quillons, wide anneau, wire-wound grip leather, covered centre studded with small boss nails. Large, round pommel. Entire length of sword, 68 inches.

\section{9\%-SWORD}

Two-handed sword. Double-edged blade 49 inches long; lunette projections on each side; flat quillons and anneau. Leathercovered grip. Octagonal iron pommel. 
Two-handed sword. Double-edged blade 44 inches long; small

lunet projections; long flat quillons; anneau on each side. Velvetcovered grip and original fringe. Small grooved iron pommel.

\section{9-SWORD}

Two-handed sword. Massive, double-edged blade 54 inches long. Armor marks of a circle and double cross, also the roolf mark of Solingen. Large lunette projections on blade. Square, drooping quillons, ending in spiral curls. Large anneau containing fleur de lis guards. Grip lacking. Grooved iron pommel. Entire length, 71 inches.

\section{0-SWORD}

Two-handed sword. Blade double-edged, 50 inches long; lunet projections on upper part; flat quillons and anneau on each side; leather grip; iron pommel.

\section{1-SWORD}

Two-handed sword. Blade double-edged, 49 inches long. Lunet projections on upper part; flat quillons and large anneau on each side; velvet grip; grooved, pear-shaped pommel. German sixteenth and seventeenth centuries.

\section{2-SWORDS}

Heavy short sword. Wide blade etched on both sides with a crown and monogram A R (Augustus Rex). Brass hilt, crown and monogram in relief. German, late seventeenth century. Six pieces.

Ditto. Six pieces.

Ditto. Four pieces.

\section{3-SWORD}

Espada or knight's sword. Forged iron hilt; straight, flat quillons; double anneau connected by counterguard; wire-wound grip; ball pommel. Flat, double-edged blade guttered on each side, $13 / 4$ inches wide. Blade, 36 inches.

\section{4-SWORD}

Espada or knight's sword. Forged iron hilt, drooping quillons, anneau and finger rings; long grip; flat pommel pierced with cord holes. Double-edged blade two inches wide at hilt, tapering to point. Blade, 36 inches. 
Spanish rapier. Pas d'ane hilt of four sections; long, straight quillons; wire wound grip; octagonal pommel. Deep groove on each side containing armorer's marks, but obscured by oxidization. Blade, $3 \%$ inches.

2406-SWORD

Rapier. Basket-guard carved and reticulated; straight twist quillons and branch; wire-wound grip; carved pommel. Flattened diamond section blade, deeply grooved on each side. Blade, 36 inches.

\section{0\%-SWORD}

Rapier. Blackened hilt. Small plates in anneau pierced with fine holes. Long, straight quillons, pas d'ane, wire-wound grip, flattened cone pommel. Wide diamond section blade deeply grooved at hilt; armorer's mark. Maltese cross. Blade, 43 inches.

\section{8-SWORD}

Rapier. Russet hilt; oval guard plates; repoussé figure of a mounted knight on each, surrounded by carved scroll and piercedwork quillons and pas d'ane of square chain pattern. Wire-wound grip; ball pommel ornamented with portrait bust and heraldic griffin in relief. Flattened diamond section blade widening at guard and engraved on each side with figure of a standing knight. Blade, 40 inches.

\section{9-SWORD}

Italian rapier. Basket-guard finely carved scroll and pierced work; wide-grooved rim folding back; straight twisted quillons and branch; wire-wound grip; elongated oval openwork panel. Diamond section blade flattened at hilt and guttered on each side. Blade, 43 inches.

\section{0—SWORD}

Rapier. Blackened hilt. Guard of two round plates pierced with small, star-shaped holes, curved quillons and knuckle guard; leather grip; octagonal pommel; hollow, triangular blade. Blade, 41 inches. 
2411-SWORD

German two-handed sword. Blade 49 inches long, with lunet projections, long, flat quillons and anneau. Leather-covered grip; original fringe; oval iron pommel.

\section{2-SWORD}

Rapier. Forged iron hilt, small straight quillons. One small anneau pas d'ane. Counter-guard of three parts uniting to form the branch which is attached to pommel. Flattened diamond section blade with armorer's mark. Blade, 42 inches.

\section{3-PRIMING HORN}

Seventeenth century priming-horn for wheel-lock. Flattened cowhorn engraved with "Tudor Rose" floral and circle ornament. Iron mountings.

\section{4-DUELLING PISTOLS}

Pair of Scotch pistols. Made by J. Bryce, Edinburgh. The barrels engraved with "Thistle." Engraved silver mountings. Yellow topaz set in each side of grip. Percussion locks with safety catches. Altered from flint locks. Priming pins screw in ends of butts.

Length, 10 inches.

\section{5-MACE}

Officer's baton of steel, in form of a ten-flanged mace. Hollow metal shaft, to hold papers.

\section{6-ARBALESTE}

German prod (asses' foot lever type), used for hunting large game. Steel bow stock and lever, butt of wood inlaid with an ivory panel on which is engraved a portrait of a lady, costume of early sixteenth century.

Bifurcated cord with socket for end of quarrel, the latter of extra size and weight with star-shaped head. Excessive rarity. 2 pieces.

\section{7-QUARREL}

Bolt for arbaleste, with steel head and short wooden shaft. Six pieces.

Six pieces. Similar to the preceding. 
Five pieces. Similar to the preceding.

2420-LANCE

Cavalry lance. Long spear-shaped blades, with octagonal sockets.

Sixteen-inch long, round wooden shafts. Six pieces.

2421-LANCE

Cavalry lance. Long flat leaf-shaped blades 16 inches long, etched with arabesque ornament. Square quillons terminating in sharp points. Round wooden shafts. Two pieces.

\section{2-LANCE}

Cavalry lance. Long, leaf-shaped flat blades etched with arabesque ornament. Small round quallons with ball ends. Round wooden shafts. Four pieces.

\section{3-HALBERD}

Flat blade; small lunet axe and hook. Length of head, 141/2 inches; secured to round shaft by side plates. Two pieces.

2424-LANCE

Cavalry lance. Long, leaf-shaped flat blade measuring 151/2 inches etched on each side, with heraldic eagle, lion and floriated ornament. Octagonal shaft entire length, 90 inches. Central Europe, later half seventeenth century. Two pieces.

\section{5-NEPAL KHANJAR}

Very fine doubly curved and fluted steel blade, decorated with gold.

Wide lunet ivory hilt. Gold damascened knuckle guard. Red velvet scabbard.

Note.-From the loot of Kandy, Ceylon, 1815.

Length, 14 inches.

2426-AFGHAN "SALAWAR"

Blade of black Khorassan steel. Straight wide back, narrowing to a sharp point. Crude ivory hilt.

Length, 16 inches.

\section{7-PAIR FRENCH DUELLING FLINTLOCK PISTOLS}

Finely chased and damascened with gold. Carved wood stocks; original wood rammers. Extra fine examples of the gunsmith's art. Early eighteenth century. 
2428-PUNJAB KHANJAR

Curved knob hilt of rock crystal. Engraved with floral ornament; plain blade, damascened in gold at hilt. Red velvet scabbard. Gilt metal mounts.

Note.-From loot of Kandy, Ceylon, 1815.

Length, 17 inches.

\section{9-FLINTLOCK 'BLUNDERBUSS PISTOL}

Gunstock grip inlaid with four-pointed ivory stars. Lock and barrel engraved. Early eighteenth century.

Length, 18 inches.

2430-SPANISH FLINTLOCK BLUNDERBUSS PISTOL

Engraved barrel and lock. Belt hook attached. Gunstock grip.

Early eighteenth century.

Length, 181/2 inches.

\section{1-GERMAN FLINTLOCK RIFLE}

Short, massive barrel, finely constructed lock, hair trigger; loading tools in pocket of butt. Original steel-mounted rammer.

Seventeenth century.

Length, 201/2 inches.

\section{2-WAR-HAMMER}

German man-at-arms weapon of early fifteenth century. Steel head with square pointed beck, steel shaft; has armorer's mark. Catch at side for attachment to belt.

2433-ARBALESTE

Length, 21 inches.

German military cross-bow. Very massive steel bow, with original cord and lashings. Stock of wood, the top covered with ivory; long carved steel trigger guard; steel ratchet windlass engraved with date 1565. Length of cross-bow, 23 inches. Two pieces.

\section{4-SPONTOON}

Massive, plain, double-edged blade, three inches wide, round socket and square quillons. Length of iron, 17 inches. Fitted to a graduated wooden shaft. Early eighteenth century.

\subsection{5-CIRCASSIAN DIRK}

Double-edged blade, deeply grooved. Armorer's mark on both sides. Silver-mounted grip and sheath, decorated with fine Neillo work. Leather belt studded with silver bosses, inscribed with Persian and Russian characters. Russian Hall-mark, $185 \%$.

Length, 22 inches. 
2436-PERSIAN "FORK," OR HALBERD HEAD

Three blades. Centre straight; outer ones wave edge. Damascened in gold.

Length, $221 / 2$ inches.

243i-CIRCASSIAN DIRK

Straight double-edged blade, deep centre groove. Faint gold damascening on one side. Walrus ivory hilt.

Length, 231/2 inches.

\section{8-DAGG}

Early type of German wheel-lock pistol. Massive brass octagonal barrel, smooth bore, steel lock and plate, engraved with an eagle and inscribed, JOAN GEORG PALZ a CARLSBAAD.

Stock of wood, ornamented with brass rosettes. The butt a large faceted wooden ball. Small curved spanner.

Length, 24 inches.

\section{9-ARBALESTE}

German hunting cross-bow. Short steel bow with original cord. Stock of wood, inlaid with oval ivory panels engraved with wild fowl, etc.; brass hand grip attached to stock. Iron catch to hold quarrel in place.

Length, 25 inches.

\section{0-PAIR GERMAN WHEEL-LOCK PISTOLS}

Finely engraved barrels. Locks have automatic pan covers. Wood stocks inlaid with ivory and pearl design of animals and scroll work. Orinigal rammers. Early sixteenth century.

Length, 25 inches.

2441-KHYBER YATAGAN

Heavy, straight blade, two inches wide at hilt, running down to a point; edged from both sides; ridged back. Silver hilt decorated with neillo work. Red velvet scabbard enclosing blade and hilt.

Length, 25 inches.

2442-ANTIQUE KHYBER YATAGAN

Black Khorassan blade. Steel and horn hilt. 
2443-KOLAPORE BATTLEAXE

Blade ornamented with hunting scenes chiselled in low relief and

damascened in gold. Shaft covered with leather. Loose leather case.

Length, 25 inches.

2444-LANCE

Cavalry lance. Small spear-shaped head, attached to shaft by long metal side plates secured with nails. Colored fringe ornament. Seven pieces.

2445-LANCE

Similar to preceding lot but without fringe ornament. Seven pieces.

$2446-H A L B E R D$

Long square section spike; lunet axe and hook pierced with round holes. Length of iron to socket, 251/2 inches. Square shafts. Two pieces.

\section{7-HALBERD}

Long square section spike, large lunet axe and hook. Length to socket, 221/2 inches. Secured to octagonal shaft by two side plates.

2448-HALBERD

Long square section spike, reticulated small lunet axe and hook.

Length of iron to socket, 25 inches. Secured to square shaft by four side plates.

\section{9-HALBERD}

Long square section spike point, curved lunet axe and hook.

Length of iron, 221/2 iriches; socketed to round wooden shaft by side plates.

\section{0-LANCE}

Cavalry lance. Long leaf-shaped flat blade, etched with arabesque ornament; round wooden shafts. Two pieces.

\section{1-ARBALESTE}

German cross-bow. Heavy short steel bow, original cord and lashings, wood stock inlaid with ivory. Hinged peep-sight and quarrel catch of brass. 
Saxon miner's ceremonial axe. Thin pointed blade pierced with openwork. Wood shaft studded with brass nails.

Length, 29 inches.

2453-PAIR OF PERSIAN JAVELINS

Steel points damascened with gold, floral pattern. Grips of embossed brass. Shafts of wood. Eighteenth century.

Length, 311/2 inches.

\section{4-PERSIAN YATAGAN}

Blade etched on both sides with inscription. Armorer's mark in-

laid with gold. Grip of walrus ivory and metal; jewelled; leather and metal mounted scabbard. Eighteenth century.

Length, 311/2 inches.

\section{5-DUTCH NAVAL BLUNDERBUSS}

Flattened oval barrel inscribed "Worauf Mann Will, Dreff ich

Das Zihl." Carved and inlaid stock; original wood rammer.

Seventeenth century.

Length, 32 inches.

\section{6-GERMAN FOWLING BLUNDERBUSS}

Flint-lock. Slender barrel, inlaid with brass. Engraved lock.

Wood stock, surface covered with floral pattern inlay of ivory and mother-of-pearl. Ivory plate, with engraved rose on each side of butt. Seventeenth century.

Length, 32 inches.

\section{5\%-ENGLISH SPORTING BLUNDERBUSS}

Short, massive barrel. Dated on lock, 1800. Made by Wright.

Length, 32 inches.

2458-PUNJAB "TALWAR," OR SABRE

Short, heavy, curved blade, with armorer's mark. Steel hilt damascened in silver.

Length, 33 inches.

\section{9-AFGHAN SABRE}

- Wide, heavy blade. Cutting edge extending on reverse side of curve; back stiffened by a raised ridge; guard of engraved metal; rosewood hilt; leather scabbard; chased metal mounts. 
2460-PLRSIAN “TABAR," OR BATTLEAXE

Curved edge blade; chiselled ornament; damascened in gold and silver. Steel shaft.

Length, 35 inches.

2461-LAHORE EXECUTIONER'S SABRE

Massive curved blade, 21/2 inches wide. Double grooves on both sides. Heavy steel hilt.

Length, 351/2 inches.

2462-PESHAWAR "SHAMSHER"

Heavy curved blade; dentulated back; point bifurcated; 9 inches. Engraved inscription on one side of the blade. Blue steel hilt.

Length, 36 inches.

2463-PUNJAB "TALWAR"

Narrow, curved blade of Damascus steel, inlaid with gold at guard.

Hilt of chiselled steel, in floral ornament.

Length, 37 inches.

2464-PUNJAB "TALWAR"

Narrow, curved blade; Damascus steel. Hilt damascened in gold, floral pattern.

Length, 38 inches.

2465-PUNJAB. "TALWAR"

Narrow, curved blade, with armorer's mark. Steel hilt damascened in gold and silver.

Length, 38 inches.

2466-PERSIAN DOUBLE BLADE, OR “AMAZON AXE"

Blades finely chiselled. Arabesque ornament. Damascened in gold and silver.

Length, 38 inches.

2467-MODERN TURKISH DRESS SABRE

Bright soft steel blade; engraved metal guard; rhinoceros horn hilt. Blue velvet scabbard. White metal mounts set with paste jewels.

Length, 39 inches.

2468-ARQUEBUS

Wheel-lock sporting rifle. Hexagonal barrel; carved and inlaid wood stock; lock plate, engraved with Diana and a stag, inscribed H. MORR a DRESDE! ornate hammer holding pyrite; original rammer and spanner.

Length, 39 inches. 
Long steel barrel; original wood rammer; stock ornamented with pierced metal inlay. Seventeenth century.

Length, 40 inches.

\section{0-MOORISH FLINTLOCK RIFLE}

Slender octagonal barrel; wood stock elaborately inlaid with mother-of-pearl, ivory and metal. Eighteenth century.

Length, 41 inches.

2471-DUTCH FLINTLOCK NAVAL BLUNDERBUSS

Flattened oval steel barrel; original rammer; stock carved with marine animals and inlaid with marqueterie. Seventeenth century.

Length, 42 inches.

247D-GERMAN WHEEL-LOCK RIFLE

Octagonal barrel; massive wooden stock; original wooden rammer with ivory end; engraved iron lock. Seventeenth century.

Length, 4.3 inches.

\section{3-SCORPION}

Military whip of fifteenth century. Four chains ending in rings attached to a short wooden shaft, latter studded with brass nails; also ring for suspension. Entire length, 41 inches.

\section{4-ARQUEBUS}

Wheel-lock sporting rifle. Octagonal barrel rifled with seven grooves. Armorer's mark and name HEINRICH REIMER stamped in. Massive lock-plate and hammer handsomely engraved; long trigger guard; wood stock inlaid with ivory ; original rammer.

Length, 44 inches.

\section{5-SCORPION}

Early type. Three chains ending in square edge; iron pellets; shaft of wood studded with brass nails. Entire length, 44 inches.

2476-RUSSIAN FLINTLOCK SPORTING RIFLE

Engraved barrel inlaid with inscription in silver. Very small calibre. Date, 1734.

Length, 49 inches.

24i\%-ARAB FLINTLOCK GUN

Long slender barrel. Engraved and reticulated metal mounts. Eighteenth century. 
2478--FORK

Hungarian war-fork. Head in shape of a two-tined fork with barbed points, decorated with small crescents and dots punched into the metal. Also on socket the letters S. A. I. Length of metal head, 15 inches. Original tassel and pompons. Shaft of wood ornamented with brass nails. Entire length, 72 inches.

\section{9-LANCE}

Cavalry lance. Long flat leaf-shaped blades, etched with heraldic eagle, lion and floriated ornament ending in storks' heads. Wooden shafts. Length, 90 inches. Three pieces.

\section{0-ANTIQUE FLAGSTAFF}

Head of Partesan type. Pierced ornament. Socket secured to shaft by side plates. Iron point on lower end. Total length, 94 inches.

\section{S1-PARTESAN}

Ceremonial partesan. Heavy blade engraved on each side with heraldic arms and the letters $\mathrm{VAFZ} \mathrm{A}$. The head socketed to round shaft and secured by side irons. Total length, 94 inches.

\section{2-PARTESAN}

Combination of a wheel-lock pistol and partesan; wide daggershaped blade attached to pistol barrel. Lock finely engraved. Inlaid wooden stock, socketed to shaft; natural knobbed shaft decorated with brass nails. Entire length, 94 inches.

\section{3- LANCE}

Cavalry lance (Ahlspiedd type). A long square section spike socketed to wooden shaft about seven feet long. Rare weapon of sixteenth century.

\section{4-TROPHY}

Mounted trophy of following articles. Heavy half-armor cuirass.

Morion; two siege burgonets; pair of mitten gauntlets; three partesans; ten swords of various patterns.

\section{5-TROPHY}

Very handsome suit of repoussé demi-armor, consisting of burgonct with hinged ear flaps, gorget of four plates, breastplate, plondrons of seven plates, mitten gauntlets, tassets of six plates. This armor is in fine condition. 
Mounted trophy, consisting of following articles: cuirass and back plate of fluted armor, pair of small plate (half armor) for arms, two partesans, two halberds, engraved spontoon, two morningstar pikes, two flails.

\section{7-TROPHY}

Mounted trophy, consisting of the following articles: repoussé iron Augsburg shield, siege burgonet, partesan, two halberds, wheel-lock gun, two long swords, two Augustus Rex short swords, pair of gauntlets.

\section{8-TROPHY}

Mounted trophy. Half-armor cuirass with attached tassettes; burgonet having peaked umbril and extra large hinged ear-flaps; a gorget to match, which is attached to burgonet by hooks; pair of very long gauntlets, one still containing original leather glove; chain-armor brayatte; two long cut and.thrust swords with wide blades.

\section{9-CAP-A-PIE SUIT OF ARMOR}

Complete suit of plate-armor mounted on lay figure. Each piece etched with heads of mythological animals and scroll pattern. On the centre of the plastron are the heraldic arms of an independent ruler, the crest being a five-barred helmet facing; two armorers' marks are stamped in the body, a Maltese cross and a Savoy shield. This suit was probably made in Milan for a German prince. Mounted with it, an etched shield and a knight's sword.

2490-CAP-A-PIE SUIT OF ARMOR

Complete suit of plate armor, mounted on a lay figure. Each piece exquisitely etched with grape vine and scroll ornament. On the right breast of the plastron in an oval panel is a figure of the Virgin with flowing hair holding the Infant Christ, and on the left a Knight of St. John kneeling with a banner and shield. The plondrons have figures of knights and grotesque heads. With the armor is a small round shield of similar decoration, and a painted tilting lance decorated with fish, an early Christian emblem. 


\title{
TENTH AND LAST AFTERNOON'S SALE
}

\author{
SATURDAY，JANUARY 2\% $2 \%$ TH 1906 \\ AT THE AMERICAN AR'T GALLERIES \\ BEGINNING AT 2.30 o'CLOCK
}

\section{EUROPEAN BRONZES}

2492-ROMAN BRONZE LAMP

Head of a satyr, supported by a claw-foot standard. Old French bronze in Italian style.

Height, 8 inches.

2493-FRENCH BRONZE VASE

Bottle-shaped. "Cupid and Psyche." By E. Barrias. Cast by F. Barbedienne.

Height, $51 / 2$ inches.

2494-BARBEDIENNE BRONZE

Two boys on turtle. Copper-red patina.

Height, 5 inches.

2495-PAIR OF BRONZE MASQUE ORNAMENTS

Old Italian.

2496-BARYE BRONZE

Alligator. Malachite-green patina.

Length, 8 inches.

2497-BARYE BRONZE

The walking lioness. Fine green patina. Cast by F. Barbedienne. Height, 81/4 inches; length, 151/2 inches. 
Eagle and dead heron. Cast by F. Barbedienne.

Height, 12 inches; length, 12 inches.

2499-BRONZE B.AS-RELIEF

The walking lion. By Barye. Cast by F. Barbedienne. Fine green patina. Mounted on an ebony panel.

Length, $21 \frac{3}{4}$ inches; height, $101 / 2$ inches.

2500-IMPORTANT BRONZE GROUP

"Jaguar and Hare." By Barye. Cast by F. Barbedienne. Fine green patina.

Length, 37 inches; height, 16 inches.

2501-BRONZE FIGURE

"Prayer." By Paul Dubois. Reduction of figure on the monument erected at Nantes to General La Moricière. Cast by Barbedienne, Paris.

Height, 39 inches.

2502-BRONZE FIGURE

Harlequin. By Saint Marceaux. Cast by F. Barbedienne, Paris. Height, 34 inches.

2503-IMPORTANT BRONZE

"Youth." By Chapy. (Reduction No. 1.) The original in marble, and belongs to the monument of Henri Regnault, Paris. Fondeur, F. Barbedienne.

Height, 461/2 inches; width, 131/2 inches.

2504-HEROIC SIZE BRONZE BUST

Ariadne. Copy from an antique in the Capitol at Rome. Cast by

F. Barbedienne.

2505-BRONZE LIFE-SIZE BUST

Shakespeare. Cast by F. Barbedienne.

2506-BRONZE LIFE-SIZE BUST

Molière. Cast by F. Barbedienne.

250\%-HEROIC SIZE BRONZE BUST

Bacchante. Cast by F. Barbedienne. 


\section{VALUABLE MISCELLANEOUS OBJECTS}

2508-CARVED ROCK CRYSTAL BOX

Design of a winged horse. Enamelled and gilded silver mountings. Height, 51/2 inches; length, 51/2 inches.

2509-ANTIQUE JEWISH SANCTUARY LAMP

Repoussé silver of fine workmanship. Seventeenth century. Arranged for ten electric lights.

Length including chain for hanging, 42 inches.

2510-MANTEL CLOCK

Louis XVI period. Heavy crystal glass plinth of oval shape and cut in diamond pattern. The clock case, which is also of crystal glass, is supported by two sphinxes wrought in ormolu. Two doves and floral design ornaments, also of ormolu, surmount the clock. Fine movement striking hours and half hours.

2511-PEARL SHELL

Decorated with a miniature painting in oil, representing the

" Birth of Christ." Has a leather case.

2512-MINIATURE PORTRAIT OF WILLIAM IV.

Painted in oil on a wood panel. Artist unknown. Carved and gilded wood frame surmounted by a crown.

Purchased at the Fitz Clarence Sale at Berwick, May 5, 1891, and stated to have belonged to King William IV.

2513-CYLINDRICAL HANGING VASE

Silver and other metals. Rich red copper patina with blossom and vine, butterfly and grasses in relief.

Height, $7 \frac{3}{4}$ inches.

2514-ANTIQUE PERSIAN BRASS JAR

Oviform, with dome-shape cover. Ornamentation of floral scrolls

finely engraved and in openwork. Incised mark underneath foot.

Height, 17 inches.

2515-ANTIQUE PERSIAN BRASS JAR

Oviform, with cover. Ornamentation of numerous medallions, flowers and scrolls engraved and in finely executed openwork.

Height, 21 inches; diameter, 9 inches. 
2516-ELABORATE CARVED ROCK CRYSTAL ORNAMENT

An egg-shape coupe on high foot; the cover of double swan shape. Surmounting the two swans' heads is a crown ornamented with seed pearls; mounting of silver gilt beautifully enamelled.

Height, 14 inches; length 7 inches.

2517-PAIR ANTIQUE FLORENTINE CANDLESTICKS

Of tall, graceful form. Made of gilded metal and elaborately ornamented with inlays of carved coral.

Height, 121/2 inches.

2518-MANTEL CLOCK

By Raiygo Frères, Paris. Gilt metal case with figure of history and decorated porcelain panels of old Sèvres style.

2518a-LOUIS XV APPLIQUÉS

A set of eight candelabra, each for three lights, of foliated scroll design, wrought in ormolu.

2519-PAIR OF CANDELABRAS

Royal Vienna porcelain vases, richly decorated, supporting wrought brass and gilded candle branches for five lights each.

Height, 24, inches.

2520-LOUIS XV WALL CLOCK

Carved and gilded wood frame. French movement.

2521-WALL CLOCK AND THERMOMETER

Louis XV design. French movement mounted in carved and gilded wood.

2522-LOUIS XV WALL CLOCK

Mounted in elaborate gilded brass. Movement by Martinot, Paris.

2523-BAROMETER AND THERMOMETER

By Ronquette, Paris. Mounted in carved and gilded wood. Louis XV design. 
Italian. Seventeenth century. This is a composition of a large number of figures, symbolizing the glorification of art in Italy at the time when Raphael and Michael Angelo were in the height of their careers. In the foreground on the left the youthful Raphael, surrounded by friends and pupils, is engaged in drawing from a group nearby arranged to represent the Virgin, the Infant and St. John with St. Joseph. Raphael turns a moment from his portfolio to follow with his eyes the progress of Michael Angelo who mounts the steps leading to the Hall of Fame, casting behind him as he goes a look of fraternal recognition toward the younger man. On either side of the figure of the great sculptor, painter and architect are statues on simple pedestals, one representing Minerva, the other Venus with a crouching centaur. In the background are the façades of several buildings, a monumental column and various other architectural features.

Height, 24 inches; length, 33 inches.

2525-CARVED ROCK CRYSTAL BOX

Design of turtle. Mounted in enamelled and chiselled silver.

Length, $71 / 2$ inches; height, $21 / 2$ inches.

\section{6-ANCIENT WROUGHT IRON TREASURE CHEST}

German. Seventeenth century. The outer surface is covered with crossed bands, with bosses at the intersection, and within numerous squares between the bands, are rosettes of hammered iron. On the reverse of lid is an elaborate lock, covered with an ornamentation of two nude female figures, with crowns, amid foliated scrolls, wrought in openwork and etched.

Height, 28 inches; length, 31 inches.

2527-LIFE-SIZE BUST

Madame Adelaide de Sardaigne. Sculptured in Carrara marble. Artist unknown.

2528-ELABORATE FOUNTAIN AND FISH BOWL COMBINED

Crystal glass bowl, with wrought bronze and gilded mountings in bamboo and openwork design. Has table of Japanese design skilfully wrought in brass and gilt. By F. Barbedienne.

Extreme height, 60 inches; diameter, 26 inches. 


\section{LOUIS XV AND OTHER FURNITURE}

2529-LOUIS XV FOOTSTOOL

Carved wood and gilded frame. Covered with silk brocade of floral designs on a silver-gray ground.

2530-SMALL WORK TABLE

Louis XV. Veneered with tulip and rosewood.

2531-LOUIS XV WORK TABLE

On graceful, slender legs. Veneered with tulip and other woods.

2532-LADIES' WORK TABLE

Louis XV. Veneered with various woods. Finely wrought metal mountings and ornaments.

2533-LOUIS XV WRITING TABLE

Marqueterie, with finely wrought brass mounts. Leather top.

2534-LADY'S LOUIS XV WRITING TABLE

Veneered with tulip and rosewood. Finely wrought ormolu mountings.

2585-LOUIS XV RECEPTION CHAIR

Carved wood and gilded frame of openwork design. Seat covered with old silk brocade of floral designs on a silver-gray ground.

2536-LOUIS XV RECEPTION CHAIR

Carved and gilded wood frame of openwo $\mathrm{k}$ design. Seat covered with old silk brocade. Red ground with floral patterns.

2537-THREE RECEPTION CHAIRS

Louis XV. Carved wood and gilded frames. Seats covered with rich silk and metal brocade of Oriental pattern.

2538-LOUIS XV RECEPTION CHAIR

Carved and gilded wood frame. Seat covered with old silk and metal brocade of the period. Design of floral branches on a silvergray ground. 
2539-LOU1S XV MARQUISE

Carved and gilded wood frame. Cane seat and back, with loose

cushion of fine silk and metal brocade of the period.

2540-LOUIS XVI ARM-CHAIR

Carved and gilded wood frame. Upholstered in old silk brocade of floral and foliated design.

2541-BERGל̀ RE

Regency period. Carved and gilded wood frame. Covered with silk brocade, of floral patterns on a cream-white ground; loose cushion.

254R-LOUIS XV ACCOUDOIR

Elaborately carved wood and gilded frame. Upholstered with silver and silk flowered brocade of the period; loose cushion.

2543-TWO LOUIS XV SETTEES

Carved and gilt wood frames. Seats and backs covercd with gobelin tapestry of the period; the seats illustrating the fables of

La Fontaine, and the backs after designs by La Prince.

2544-TWO LOUIS XV SETTEES

'To match the preceding.

2545-LOUIS XV FIRE SCREEN

Carved and gilded wood frame. Panel of very fine antique $\mathrm{Au}^{-}$ busson tapestry. (Gobelin stitch.) A deer and doe surrounded by a border of rich floral design.

2546-LOUIS XIV FIRE SCREEN

Aubusson tapestry panel of the period. Design of poppies in low tones. Carved and gilded wood frame.

\section{$2547-A C C O U D O I R$}

Regency style. Carved and gilded wood frame. Upholstercd in silk brocade of the period; loose cushion.

\section{8-LOUIS XV MARQUISE}

Elaborately carved and gilded frame of cupid, floral and foliated designs. Upholstered in silk brocade of the period; floral design; loose cushion. 
Carved wood and gilded frame. Covered with silk brocade of the period; bold floral and foliated patterns on a silk and silver ground; loose cushion.

2550-LOUIS XV MARQUISE

Carved wood and gilded frame. Covered with silk brocade of the period. Vase of flowers and branches in bright colors on a creamcolor ground; loose cushion.

\section{1-LOUIS XV BERG'̀RE}

Frame of carved and gilded wood, of elaborate design. Upholstered in silk and metal brocade of the period. Sprays of flowers and other patterns on a silver-gray ground; loose cushion.

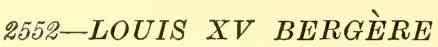

Elaborately carved and gilded wood frame. Upholstered in silk brocade of the period; design of flowering plants in bright colors; loose cushion.

\section{3-LOUIS XV FOLDING SCREEN}

Three folds. Elaborately carved wood and gilded frame, with figure of Cupid and foliated scrolls; the lower panels of old silk brocade and the upper panels of bevelled crystal glass.

2554-ROMAN FOLDING SEAT

Of classic design, in elaborately carved walnut. With loose cushion of red and old gold brocade.

2555-LOUIS XV TABLE

For miniatures and gems. Elaborately carved and gilded wood; bevelled crystal glass in top, sides and ends; plush-lined.

2556-LOUIS XV BOUDOIR WRITING TABLE

French burl walnut. Gilt brass mountings and candle branches; the latter arranged for electricity.

255\%-LOUIS XV CHAISE LONQUE

Carved and gilded wood frames. Upholstered in rich flowered silk and metal brocade; loose cushions. 
2558-LOUIS XV CORNER CUPBOARD

French walnut and fine marqueterie. Mounting of finely wrought brass; marble top.

2559-LOUIS XV CORNER CUPBOARD

French walnut and marqueterie. To match the preceding.

2560-LOUIS XV COMMODE

Swept front and sides and with cabriole legs; veneered with tulip and rosewood; marqueterie panel in front. Elaborate mounts wrought in ormolu. Marble top.

2561-LOUIS XV COMMODE

Swept front and sides and cabriole legs. Veneered with rosewood and ornamented with elaborate mounts of ormolu. Sienna marble top.

2562-PAIR CONSOLS

Louis XV design. Carved and gilded wood. Cippolini marble tops.

2563-TWO TALL PEDESTALS

Chinese teakwood, beautifully inlaid with designs in mother-ofpearl.

2564-CHINESE TEAKWOOD SCREEN

Four folds. Elaborately carved frame. Panels of fine needlework: birds and flowers embroidered in bright colored silks on black satin.

2565-PARLOR CABINET

Carved oak, with plush-covered back. Top enclosure with bevelled glass in doors. Enclosure in base and various shelves.

2566-ELABORATE PARLOR CABINET

Rosewood, inlaid with pear wood. Has three enclosures and various shelves; beautifully lacquered Japanese panels in the doors of lower enclosure.

Outside measurement, height, 631/2 inches; length, 73 inches.

2567-LARGE ROSEWOOD CABINET

Inlaid with pear wood. Top panel with bevelled mirror and plushcovered border. Has various shelves and enclosure; the doors of the latter have panels of Japanese lacquer-work.

Height, 80 inches; length, 88 inches. 
Companion to the preceding.

Height, 80 inches; length, 88 inches.

2569-LARGE WALL CABINET

Chinese teakwood. Elaborately carved designs of dragons and cloud forms in openwork. Glass front, sides and shelves.

Height, 66 inches; width, 62 inches.

25:0-STONE GARDEN LANTERN

Old Japanese.

Height, 35 inches.

\section{AN'TIQUE CHINESE RUGS}

25\%1-CHINESE RUG

Heavy pile. Ivory-white ground, with flowers of paradise amid

foliated scrolls in blue, yellow and red.

Length, 5 feet 11 inches; width, 3 feet 8 inches.

2572-ANTIQUE CHINESE RUG

Silky pile. Golden brown ground, with passion flowers amid elab-. orate foliations in bleu de Nankin and other colors.

Length, 6 feet 10 inches; width, 3 feet 9 inches.

25\%3-ANTIQUE CHINESE RUG

Silky pile. Salmon-pink centre panel, with floral and Greek fret medallion and corners; vases of flowering plants, symbols and objects of art in two shades of blue and ivory-white, surrounded by a wide border of Greek fret and Svastski symbols and several narrow borders.

Length, 6 feet 8 inches; width, 4 feet 7 inches.

25\%4-ANTIQUE CHINESE CARPET

Silky pile. Ivory-white centre with floral medallions, objects of art, symbols and floral sprays in two shades of bleu de Nankin; border of floral scrolls and svastika, with an outer band of solid blue.

Length, 12 feet 7 inches; width, 5 feet 10 inches.

\section{5\%5-ANTIQUE SILK SAMARKAND CARPET}

Centre panel of jade-green and mandarin-red, with pendant medallions and floral designs in low tones. Border of Greek fret and wave designs in blue and ivory-white on a red ground.

Length, 12 feet 7 inches; width 6 feet 4 inches. 
Of fine weave and silky pile. On a yellow ground is a centre medallion of the Svastika and dragon symbols in dark blue. Surrounding the medallion is a profuse embellishment consisting of numerous flowers of paradise amid foliations in ivory-white and bleu de Nankin. The corner ornaments conform with the central medallion; a wide border of Greek fret in salmon-pink and floral scrolls in ivory white on a dark blue ground, and a series of narrow borders complete the design.

Length, 12 feet 11 inches; width, 9 feet 1 inch.

\section{7-ANTIQUE CHINESE CARPET}

Sky-blue centre, with medallion of passion flowers and foliations, butterflies and floral sprays, red, yellow and ivory-white. Surrounded by a border of Greek fret, and two outer bands of salmonpink and dark blue.

Length, 16 feet 8 inches; width, 11 feet 3 inches.

\section{ANTIQUE EMBROIDERIES}

2578-ANTIQUE ITALIAN EMBROIDERED PANEL

This elaborate piece of seventeenth-century silk embroidery illustrates the triumph of Joseph as described in Genesis, Chap. 41, particularly in Verse 43, where it says that Joseph rode in Pharaoh's second chariot after his successful interpretation of the ruler's dreams.

The young man, in rich flowing robes, with a jewel-studded turban on his head, is half reclining in a gorgeous chariot drawn by two prancing white steeds, preceded by a mounted herald sounding a trumpet. Groups of people do homage as the chariot rolls past. In the surrounding landscape, which is distinctly Italian in character, are many evidences of prosperity in the land. On the right, beyond the herald, is a busy scene of harvesting, and, on the extreme left, a shepherdess drives her flock across a bridge toward a busy corn mill. In the foreground on the left is a kneeling figure binding a sheaf of wheat, and on the right stands a peacock with widespread tail.

The composition is surrounded by a gold-colored border with supporting angels, and bunches of flowers in natural size embellish the corners. In the middle, directly below the chariot, two cupids hold a scroll bearing the words: "GEN. 41 ITE AD JOSEPH." Framed under glass. 
25\%9-ANTIQUE PERSIAN EMBROIDERY

Mass of floral designs in fine needlework on linen.

Lengih, 34 inches; width, 14 inches.

2580-ANTIQUE SPECIMEN OF NEEDLEWORK

Roumania. Carnations and lilies in Indian red and dark green on camels-hair cloth. Sixteenth century.

Length, 55 inches; width, 25 inches.

2581-TURKISII TABLE COVER

Light écru satin, with gold and silver thread embroidery of floral designs and foliation. Sixteenth century.

Length, 48 inches; width, 48 inches.

2582-ANTIQUE PERSIAN EMBROIDERY

Palmettes and floral designs in bright colors on a yellow ground.

All in elaborate needlework. Sixteenth century.

Length. 68 inches; width, 54 inches.

2583-TURKISII IIANGING

Broussa needlework. Écru satin, elaborately embroidered with silks and gold and silver threads. Mosque window design and centre medallion of fruits and flowers. Fringe of floral designs in colors.

Lined with blue satin. Nineteenth century.

Length, 78 inches; width, 47 inches.

2584-INDO-PORTUGUESE COVERLET

Covered with a mass of needlework in golden-yellow silk cord, with animals, symbols and foliations. Lined with Indian chintz. Sixteenth century.

Length, 96 inches; width, 81 inches.

\section{ANTIQUE JAPANESE TEXTILES AND EMBROIDERIES}

2585-TWO FUKUSAS

One drab silk crêpe with crest of Daimio Hori of the province of Shinano, in white reserve; one dark blue satin with crest in plum color braid, and the other of plum color silk brocade, with a design of a raised pathway through an iris field.

\section{6-TWO FUKUSAS}

One golden brown silk with the family crest of Midsuno, a Daimio of Suruga, in black threads, and lined with light blue silk; the other of sage-green silk, with crest of Daimio Honda of Mutsu, in silver-gray threads; lined. 
Dark blue gros grain silk, with the family crest of Makino, a

Daimio of the province of Tango, within a circle in white and light blue threads.

2588-FUKUSA

Sage-green gros-grain silk, with the family crest of Inaba, a

Daimio of Yamashino, in fine black silk cords.

2589-FUKUSA

Brilliant red cloth, with the family crest of Matsudaira, of Suruga, in white cord. Lined with imperial yellow satin damask.

2590-FUKUSA

Woven silk tapestry. Crest and symbol "Hōshino-tama" (Sacred

Pearl), in various colors and gold thread on a blue ground.

2.591-FUKUSA

Brilliant crimson gros grain silk, with crest in white silk cord.

2592-FUKUSA

Dark green silk, with the family crest of Hachisuga of Awa in white silk cord. Lined with crimson crêpe.

2593-FUKUSA

Cream-color silk crêpe; embellished with floral basket, finely painted in natural colors and enhanced by gold thread embroidery. Lined with red silk crêpe.

2594-FUKUSA

Red gros grain silk, with turtle of longevity and foliation brocaded in silvery white. Lined with white silk.

\section{5-FUKUSA}

Clouded silk crêpe. Sake jars and shore scene in hand painting and embroidery. Brocaded crest in red and white on reverse.

\section{6-FUKUSA}

Dark blue satin, with the family crest of Omura, a Daimio of Hizen, beautifully executed in fine white silk cord. Lined with red silk crêpe.

2597-FUKUSA

Dark blue silk, with the family crest of Goto, a Daimio, island of Goto, Hizen, in turquoise-blue silk. 
Dark blue satin, with crest in gold thread. Lined with old gold satin.

\section{9-FUKUSA}

Black silk, with the family crest of Abé, a Daimio of Kazusa, in black silk cord.

2600-FUKUSA

Écru silk, with diaper pattern in drab; crest in gold thread. Lined with red.

2601-FUKUSA

Light blue satin, with carp in gray silk needlework and turbulent water in gold threads. Lined with red crêpe.

33 by 26 inches.

\section{2-OBI}

Old silk brocade. Brown satin ground with stripes of chrysanthemums and kiri crests in a lighter shade and bordered with yellow.

$2603-O B I$

Old silk brocade. Golden-brown ground, with patterns in slate color.

\section{$2604-O B I$}

Old silk brocade. Dark blue ground covered with scroll patterns, and with stripes of conventional birds in light blue and golden brown.

2605-OBI

Dark blue velvet, with kiri crests in darker shade and pine branches and cloud forms in silk cord and gold thread.

2606-OBI

Blue silk ground, with peonies and butterflies in cut and uncut velvet in two shades of purple.

260\%-JAPANESE TABLE COVER

Sage-green silk, with designs of phœnix, fabulous animals, of cloud forms, embroidered in low tones of silks and braids. Brocade border and silk lining. 
2608-TABLE COVER

Old Japanese. Purple silk brocade; storks in yellow, green, blue and gold, and irregular shaped lines in silver gray. Lined with blue silk.

Length, 73 inches; width, 41 inches.

2609-OLD JAPANESE SILK BROCADE

Golden-brown ground, with chrysanthemum sprays and foliations in low tones of green and lavender.

Length, 52 inches; width, 48 inches.

2610-OLD JAPANESE SILK BROCADE

Scrolls and diapers on a golden-brown ground.

Length, r4 inches; width, 52 inches.

2611-OLD JAPANESE BROCADE

Dark green gros-grain silk, with irregular lines and detached chrysanthemums brocaded in golden brown.

Length, 58 inches; width, 56 inches.

2612-TABLE COVER

Old Japanese silk brocade. Dark blue ground with pine and bamboo branches and fan designs in dark green and golden brown. Edged with pink silk.

Length, 51 inches; width, 42 inches.

2613-JAPANESE WALL DECORATION

Dark blue satin with elaborate embellishment in fine needlework. A scene illustrating a ceremonial gathering of priests, dignitaries and royal personages embroidered in various silks and gold thread. Richly bordered with cloth of gold. Lined with silk brocade.

Width, 35 inches; length, 43 inches.

2614-TABLE COVER

Old Japanese silk brocade. Crest, Hōwō bird and floral sprays brocaded in silver gray. Edged with red silk.

Width, 52 inches; length, 52 inches.

2615-JAPANESE EMBROIDERED PANEL

Écru satin, with scrolls containing birds, cherry blossoms, butterflies and crests and other designs beautifully embroidered in low tones of silk and gold thread. 
Écru satin, with two birds of paradise beautifully embroidered in low tones of silk and low thread.

Width, 271/2 inches; length, 28 inches.

\section{7-JAPANESE EMBROIDERED PANEL}

Pale blue gros grain silk, with various crests and symbols beautifully embroidered in seed stitch with silks of harmonious tones.

\section{8-JAPANESE EMBROIDERED PANEL}

Cream-white gros grain silk, with various crests and symbols beautifully embroidered in seed stitch with silks of harmonious tones.

\section{9-ANTIQUE JAPANESE WALL HANGING}

Tiger, phœnix, cloud forms and wave designs profusely embroidered in various silks and gold thread.

Length, 80 inches; width, 57 inches.

\section{0-JAPANESE SILK TAPESTRY HANGING}

View of a garden in which are gathered dignitaries, artists and philosophers, woven in various colors and enhanced by gold threads.

Length, 7 feet 6 inches; width, 4 feet 6 inches.

2621-RICH JAPANESE HANGING

Gold and silk brocade. Storks in flight, clusters of chrysanthemums, cloud forms and fan designs woven in gold threads and shaded silks on an ecru ground.

Length, 80 inches; width, 66 inches.

\section{2-JAPANESE SILT TAPPESTRY HANGING}

Garden scene, figure of sage, stork, dignitary and attendant, plum tree in blossom, rocks, etc., woven in low tones and gold thread.

Length, 7 feet 3 inches; width, 4 feet 6 inches.

2623-CUT VELVET PANEL

A view of the famous red lacquer bridge at Nikko-destroyed by flood, 1902. Framed in Japanese wood and fabric.

Height, 33 inches; length, 36 inches.

2624-CUT VELVET PANEL

Crow on branch of willow tree in moonlight.

Height, 27 inches; length, 33 inches.

2625-CUT VELVET PANEL

"Eagle in Flight," over waves.

Height, 341/2 inches; width, 33 inches. 
2626-CUT VELVET PANEL

Blackbird on branch of cherry tree and Kiyomidsu Temple, Kioto, by moonlight.

Height, 341/2 inches; width, 33 inches.

2627-CUT VELVET PANEL

Crow on willow tree, at night. By Kiō-shū.

Height, 241/2 inches; length, 36 inches.

2628-CUT VELVET PANEL

Mandarin ducks-on stream and bamboo grass. By Kiō-shū.

Height, 241/2 inches; length, 36 inches.

2629-CUT VELVET PANEL

Monkey on plum tree watching sparrow. By Kiō-shū.

Height, 241/2 inches; length, 36 inches.

2630-CUT VELVET PANEL

View of Mount Fujiyama from Lake Hakone by moonlight. By Kiō-shū.

Height, 241/2 inches; length, 36 inches.

2631-CUT VELVET PANEL

Beautifully executed design of lotus plants and kingfisher.

Length, 32 inches; width, 28 inches.

2632-PANEL

Embroidery on black satin. A fox in reddish brown and partial sight of the moon in clouds.

Height, 251/2 inches; length, 271/2 inches.

\section{JAPANESE COSTUMES}

2633-KIMONO

Fine figured silk brocade. Unlined.

2634-DAIMIO JACKET

Fine figured silk brocade; light brown color with diaper, arabesques and dragon crests in low tones. Finely lined and bears crest of former owner. 
2635-ANTIQUE KIMONO

Rich figured silk brocade; crest and floral designs on a golden ground. Lined with red silk crêpe which is handsomely embellished.

2636-SUMPTUOUS KIMONO

White figured silk crêpe, embellished with trailing feathers, embroidered in elaborate gold thread embroidery.

2ॅั37-II ANDSOME KIMONO

Golden brown satin, richly ornamented with Daimio's figures and garden scene, embroidered in silk and gold thread. Lined with red crêpe.

2638-SUMPTUOUS KIMONO

Dark blue satin; beautifully embroidered embellishments of butterflies and cord and tassel design in fine needlework in various colors of silks enriched by gold threads. Lined with cherry color satin.

2639-IMPERIAL CEREMONIAL ROBE

This garment is composed of five very long robes inside each other. The outside robe of cream-white silk covered with a chrysanthemum crest in brocade, and lined with crimson. The other four robes are of white silk with brocade fronts and alternately lined with salmon, green, dark green and lavender silks.

2640-WHITE CRÊPE KIMONO

Ornamented with storm dragons, cloud forms and sacred pearl painted in various colors.

2641-SILK CRÊEE KIMONO

Decorated with dragon designs finely painted in various colors.

2642-DAIMIO DIVIDED SKIRT

Brilliant red gros-grain silk of fine quality.

2643-DAIMIO DIVIDED SKIRT

Lavender silk, with crest designs brocaded in a lighter shade; with belt and sashes. 
Blue silk brocade, with birds and foliations in golden brown.

2645-JAPANESE DIVIDED SKIRT

Fine silk brocade; striped and floral designs in browns, yellow and gold.

פ646-JAPANESE DIVIDED SKIRT

Drab silk with scrolls designs in purple.

2647-D AIMIO $C O A T$

White cloth, lined with orange-yellow satin. Bears crest in gold and wrought brass ornaments.

\section{8-MAGNIFICENT CLOTH OF GOLD}

Six lengths of costly gold brocade of stork and bamboo design from the loom of the celebrated weaver in art fabrics, J. Kawashima, Kioto, weaver, by appointment, to his Imperial Majesty's household of Japan.

$$
\text { Each, length, 411/4 yards; width, } 26 \text { inches. }
$$

\section{9-JAPANESE FIRE SCREEN}

Artistic needlework panel of river view, bamboo, birds and mountain scenery. Reverse, bamboo and sparrows, by moonlight, painted on silk. Fine black and gold lacquer frame.

Height, 41 inches; width, 34 inches.

2650-OLD JAPANESE SILK TAPESTRY PANEL

Garden scene, with various figures playing games, serving tea, writing poetry and in other occupations. Woven in silks of low tones and metal thread. Framed in embroidered plush.

Height, 73 inches; width, 521/2 inches.

2651-OLD JAPANESE SILK TAPESTRY

Companion to the preceding. An assemblage of dignitaries, Daimios and others, in a garden beneath a cherry tree. Woven in subdued colors of silks and metal thread. 


\section{SUMPTUOUS CHINESE COSTUMES AND EMBROID- ERIES}

2652-CHINESE LADY'S ROBE

Dark blue satin, beautifully embroidered in blue and gold with butterflies, flowers and leaves. The sleeves are faced with white satin, embroidered with garden scenes, flowers and arabesques. A border of similar design around the robe. Lined with blue satin.

2653-CIIINESE SHORT ROBE

Blue brocade velvet. Lined with figured blue silk.

2654-CHINESE LADY'S ROBE

Orange yellow satin, with sprays of flowers and butterflies beautifully embroidered in brilliant colors of silk. 'The sleeves with a deep facing of pale gray crêpe, and embroidered flowers and butterflies and with a narrow border like the collar.

2655-CHINESE ROBE

Brilliant crimson satin, with elaborate needlework embellishment of flowers, fruits and butterflies, in brilliantly combined silks. Bordered with blue satin which is embroidered in light shades. Lined with imperial yellow silk.

2656-MANDARIN ROBE

Dark blue satin, with an elaborate woven design of dragons, cloud forms, fire emblems and Sacred Pearl. Lined with silk.

265\%-CHINESE LADY'S ROBE

Dark blue satin, with woven designs in gold. Trimmed with embroidered bands.

2658-CHINESE LADY'S ROBE

Dark blue satin. Flowers and ornaments embroidered with bright color silks. Lined with yellow silk.

2659-MANDARIN ROBE

Crimson silk, with medallions of dragons, cloud forms and symbols and "shou" mark woven in gold threads. Round the bottom a deep border of wave designs and cloud forms. Lined with figured green silk. 
Dark blue silk, with designs of floral baskets, butterflies and symbols in low tones of silk; beautifully trimmed. Lined with light blue silk.

\section{1-SUMPTUOUS IMPERIAL ROBE}

Dark blue silk; entirely covered with gold needlework depicting a five-clawed horned dragon clutching the Sacred Pearl, flowers of paradise amid leafy scrolls, and various symbols of happy omen. Round the bottom a deep border of wave designs and a collar to correspond. Lined with pale blue silk.

\section{2-MAGNIFICENT MANDARIN ROBE}

The whole garment is covered with elaborate needlework. The designs are imperial dragons, Sacred Pearl, fire emblems and numerous symbols of happy omen. A deep border round the bottom of wave designs. Lined with figured blue silk.

\section{3-ELEGANT MANDARIN ROBE}

Plum color silk gauze. Elaborate ornamentation in fine needlework of imperial dragons, cloud forms, sacred pearls and numerous symbols, in bright colors of silk and gold thread. Lined with silk gauze.

\section{4-CHINESE LADY'S ROBE}

Brilliant crimson satin, with needlework flowers, fruits and butterflies. Lined with figured blue silk.

\section{5-RICH CHINESE ROBE}

Black satin, covered with a Greek fret design in gold thread and medallions of flowers and symbols in bright colors of silk. The sleeves have a facing of yellow satin embroidered in bright colors of silks with vases of flowers and symbols. Lined with figured blue silk.

\section{6-MANDARIN ROBE}

Golden yellow brocade silk. Richly embellished-with needlework, dragons, cloud forms, fire emblems, floral sprays and numerous symbols and happy omens, embroidered in bright colors of silk and gold thread. 
Crimson satin, covered with a gold embroidered fret design, with intervening medallions of flowers and butterflies embroidered in two shades of blue silk. Lined with figured blue silk.

\section{8-SUMPTUOUS IIANDARIN ROBE}

Wine color satin, elaborately embroidered in silks and gold threads, with imperial dragon clutching the Sacred Pearl, cloud forms, wave designs and numerous symbols of long life and happiness. Lined with blue silk.

\section{9-CHINESE SHORT ROBE}

Wine color brocade velvet; peonies and Greek fret designs in relief.

Sleeves faced with needlework.

\section{0-CHINESE LADY'S ROBE}

Crimson satin, embellished with needlework medallions of symbolical designs embroidered in gold thread. Lined with blue satin.

2671-CHINESE SHORT ROBE

Plum color brocaded velvet. Sprays of peonies and butterflies in darker shade. Lined with figured blue silk.

\section{7\%-CHINESE ROBE}

Salmon color silk gauze, beautifully embellished with butterflies, gourds and floral scrolls embroidered in bright colors of silk.

2673-CHINESE LADY'S ROBE

Dark blue brocade velvet. Floral sprays and bat symbols in a darker shade in low relief. Lined with blue silk.

2674-CHINESE ROBE

Deep plum silk; with brocade medallions and richly embroidered panels.

\section{5-CHINESE LADY'S ROBE}

Dark blue brocaded velvet. Floral spray and butterflies in a darker shade. Sleeve faced with light blue.

\section{6-CHINESE LADY'S ROBE}

Black velvet, richly embellished with floral sprays, butterflies and symbols in fine needlework. Sleeve faced with red velvet and embroidered. Lined with figured red silk. 
Golden yellow silk velvet, divided into panels by narrow strips of black satin. The panels are covered with Chinese needlework in designs of vases, flowers, fans, objects of art and symbols. A border all around the bottom of floral designs and a narrow fold of black satin.

2678-CHINESE SKIRT

Crimson satin, made in panels which are joined by narrow strips of black satin. Embroidered in silks and gold thread with sacred elephants in rich trappings and figures of Chinese children holding lotus flowers aloft.

26\%9-CHINESE SKIRT.

Light green satin, finely embroidered with design of flowers, symbols and birds in finely combined colors.

2680-CHINESE SKIRT

Golden orange velvet, embellished with peonies, clusters of peach fruit and pomegranates in fine needlework.

\section{1-CHINESE SKIRT}

Green satin, richly embellished with fine needlework. Five-clawed dragon arising from the sea and pursuing the Sacred Pearl, flowers and symbols, beautifully embroidered in gold thread and various silks.

\section{2-CHINESE SKIRT}

Deep orange color cut velvet, in design of peonies and butterflies, with embellishment of Chinese needlework appliqués of flowers and symbols of happy omen, trimmed with embroidery and lined with brocaded blue silk.

2683-CHINESE DIVIDED SKIRT

Crimson silk brocade. Richly embroidered in silks and gold thread, with clusters of flowers and fruits and butterflies.

2684-CHINESE DIVIDED SKIRT

Light blue silk, covered with brocaded design of Greek fret. 
With long sashes. Pineapple gauze. Needlework and painted ornamentation.

\section{6-MANDARIN JACKET}

Of rich gold and silk brocade, and trimmed with red cloth.

\section{8\%-IMPERIAL BANNER}

Yellow satin, with a five-clawed dragon, the Sacred Pearl, cloud

forms fire emblems and the bat symbol embroidered in bright colors of silk.

\section{8-IMPERIAL BANNER}

Crimson satin, with a dragon and other symbols embroidered in bright colors of silk.

\section{9-PAIR EMBROIDERED PENDANTS}

Old Chinese. Green satin, with birds, flowers and other designs in fine Chinese needlework; fringed at bottom.

2690-OLD CHINESE SILK FRINGE

Turquoise-blue, with knots of red and gold.

Length, 7 feet; width, 13 inches.

2691-PAIR HEAVY SILK TASSELS

With long cords. Salmon-red. Old Chinese.

2692-SPECIMEN OF CHINESE NEEDLEWORK

Various birds, tree peony and willow tree exquisitely embroidered in silks of various colors on a white ground. Yung Chêng period. Framed in carved teakwood.

Diameter, 16 inches.

2693-ANTIQUE CIIINESE WALL PANEL

Woven and painted silk. Ornamented with views of interiors, garden and domestic scenes, mountains and river views beautifully executed in harmonious colors. Inscribed with a stanza of a Chinese poem on Spring by Yen riūkei. Framed in gilded wood of bamboo design. 
Silk and gold tapestry. Design of imperial dragon and symbols woven in bright colored silks and gold thread.

Length, 64 inches; width, 19 inches.

2695-ANTIQUE CHINESE WALL HANGING

Crimson satin, richly embellished with Chinese needlework, flowers, ornament and symbol embroidered in gold thread and silks.

Length, 61 inches; width, 21 inches.

2696-PALACE CURTAIN

Antique Chinese. Crimson satin, with vase of flowers, objects of art and symbols beautifully embroidered in colored silks and gold thread; with green satin lambrequin, which is embroidered with ornaments and appliqué inscription and seal.

Width, 36 inches; length, 38 inches.

2697-PAL.ACE CURTAIN

Antique Chinese. Silk and gold brocade design of storks, rising sun, cloud form and symbols beautifully woven in gold and colors. With plum color lambrequin and brocade design of various ornaments.

Length, 38 inches; width, 36 inches...

2698-PAIR ANTIQUE CHINESE WALL PANELS

Crimson satin, richly embroidered in gold threads, four-clawed dragons pursuing the Sacred Pearl, Fêng-Huang birds, floral scrolls and wave design.

Length, 64 inches; width, $221 / 2$ inches.

2699-ANTIQUE CHINESE PALACE CURTAIN

Crimson satin, embroidered to correspond with the preceding. Width, 36 inchos; length, 38 inches.

2700-PAIR PALACE CURTAINS

Antique Chinese. Crimson satin richly embellished with needlework - vase of flowers, objects of art, floral sprays and symbolical bat-beautifully embroidered in various silks and gold threads. With embroidered green lambrequins.

Length, 38 inches; width, 36 inches.

2Y01-PAIR SUMPTUOUS PALACE CURTAINS

Antique Chinese. Red satin brocade. Bold dragon, cloud forms, Sacred Pearl and wave designs woven in gold threads and bright colors of silks. With green satin brocade lambrequin.

Width, 36 inches; length, 36 inches. 
2702-PAIR SUMPTUOUS WALL PANELS

To match the preceding.

Length, 62 inches; width, 21 inches.

2703-SUMPTUOUS PALACE HANGING

Crimson satin. Rich embellishment in needlework of sacred elephant, symbols, floral sprays and cloud forms embroidered in gold thread and bright colors of silk.

Length, 38 inches; width, 36 inches.

2704-SILK TAPESTRY PALACE CURTAIN

Antique Chinese. Dragon clutching the Sacred Pearl, the bat symbol, "shou" marks, cloud forms and wave designs woven in gold threads and bright colors.

Lengih, 37 inches; width, 36 inches.

\section{5-PAIR SILK TAPESTRY WALL PANELS}

To match the preceding.

Length, 63 inches; width, 20 inches.

\section{6-PALACE CURTAIN}

Antique Chinese. Crimson satin, ornamented with various ornaments and objects of art, embroidered in finely combined colors of silk and gold thread. Embroidered green satin lambrequin, with Chinese characters and seal marks in appliqué.

Length, 38 inches; width, 36 inches.

\section{7-PALACE CURTAIN}

Antique Chinese. Crimson satin richly embellished with a fourclawed dragon, the Sacred Pearl, flying bats, symbol of long life; cloud forms, wave designs and Fêng Huang birds embroidered in gold threads.

Length, 40 inches; width, 36 inches.

2708-PAIR ANTIQUE CHINESE WALL PANELS

Dark blue satin, with storks, symbols and crest woven in gold thread and colored silks.

Length, 66 inches; width, 201/2 inches.

2709-PAIR ANTIQUE CHINESE WALL PANELS

Crimson satin, with elaborate woven designs of dragons, sacred pearl, cloud forms and symbols of happy omen.

Length, 61 inches; width, 20 inches. 
2710-PAIR ANTIQUE CHINESE WALL HANGINGS

To match the preceding.

2711-PAIR ANTIQUE CHINESE WALL HANGINGS

Crimson satin, richly ornamented with flowers, ornaments and symbolical designs in gold thread and silk needlework; with long tassel pendants.

Height, 59 inches; width, 20 inches.

2712-SET OF EIGHT WALL PANELS

Antique Chinese. Beautiful quality of cut velvet, green ground, with floral medallions, dragons and various symbols in crimson.

Each, length, 70 inches; width, 21 inches.

\section{3-ANTIQUE CHINESE LAMBREQUIN}

Elaborate design of dragons, symbols, cloud forms embroidered in gold thread and various colors of silks on dark blue satin.

Height, 24 inches; length, 74 inches.

2714-LARGE PALACE LAMBREQUIN

Antique Chinese. Dark blue satin, embellished with numerous objects of art, branches of plum blossoms, peonies and magnolias and various symbols; all beautifully embroidered in various silks, to imitate porcelain, lacquer, ivory and other materials.

Length, 74 inches; width, 38 inches.

\section{CHINESE EMBROIDERY}

2715-ANTIQUE CHINESE PALACE LAMBREQUIN

Domestic scenes and landscape views in three panels embroidered in various low-toned silks on yellow color satin. Borders of flowers and birds.

$$
\text { Length, } 5 \text { feet; width, } 16 \text { inches, }
$$

2716-PAIR ANTIQUE CHINESE CURTAINS

Red satin, with bold dragon embroidered in gold thread, and cloud

forms and wave designs in various colors of silks. With blue satin lambrequin.

2\%1\%-ELABORATE PALACE HANGING

To match the preceding. 
Crimson satin. Various ornaments, symbols and flowers in appliqué and embroidery.

Length, 66 inches; width, 43 inches.

2719-ELABORATE PALACE LAMBREQUIN

Antique Chinese. Crimson satin richly embellished with a needlework ornamentaton consisting of numerous vases, symbols of happy omen, flowers, scrolls and other designs. All embroidered in finely combined colors of silk, heavily fringed.

Height, 40 inches; length, 150 inches.

\section{0-ELABORATE PALACE HANGING}

Antique Chinese. Crimson satin, with a rich embellishment in needlework-consisting of sacred elephant, numerous symbols, ornaments, cloud forms and other designs. Heavy fringe border.

II eight, 83 inches; length, 106 inches.

\section{1-SUMPTUOUS PALACE LAMBREQUIN}

Crimson satin, elaborately embellished with symbolical designs, ornaments and cloud forms embroidered in gold threads; blue and white silk.

Length, 12 feet; width, 25 inches.

\section{2-ELABORATE PALACE HANGING}

Antique Chinese. Dark blue satin, richly embellished with imperial dragons arising from the sea and pursuing the Sacred Pearl, cloud forms, fire emblems and Buddhistic symbols of happy omen, embroidered in gold thread and brilliant color of silks.

Length, 10 feet; width, 7 feet.

\section{3-IMPERIAL PALACE HANGING}

Antique Chinese. Yellow silk, with an elaborate embellishment in Chinese needlework, consisting of five boldly designed imperial dragons, the central one blatant and clutching the Sacred Pearl, symbols of happy omen, and numerous cloud forms; all embroidered in gold thread and yellow silk. Ch'ien-lung period.

Length, 91/2 feet; width, 8 feet.

\section{4-GRAND TEMPLE HANGING}

Antique Chinese. Golden yellow satin; the centre panel is decorated with Chinese characters in India ink, which is surrounded by a wide border of needlework, depicting figures of sages, dignitaries, flowers, objects of art and symbolical designs; embroidered in yellow silk. Ch'ien-lung period. 


\title{
SECOND EVENING'S SALE
}

\author{
MONDAY, JANUARY 22D, 1906
}

A'T THE AMERICAN AR'T GALLERIES

BEGINNING AT 8 o’CLOCK

\section{ANCIENT CHINESE, THIBETAN AND JAPANESE PICTORIAL ART}

Catalogued by Professor Ernest Fenollosa

\section{5-THIBETAN ALTAR-PIECE}

Probably seventeenth century. Such pieces are in the form of Mandara, magical circles or arrangements of deities and symbols to be invoked in ritual service. It seems derived from the same Indian root as the Shingon sect known in Japan. This represents some phase of Lamaistic church ceremonial, the central figure with pointed cap being a Lama deified, while other Lamas are seen in some of the smaller groups. Like most of the Thibetan altarpieces, this is painted upon canvas and in a medium that seems to be a thin oil. Its artistic quality is hieratic, a formalized type descended from ancient creative work; but work of this sort as early as the seventeenth century, when Lamaism was taking strong: hold upon China in Peking, is often very delicate and beautiful, like our high European types of illuminated manuscript. This is a beautiful example of delicate and graceful touch, especially as seen in the lower figures on the left. This, and the series that follow, were probably taken from some Lamaistic temple in Peking; some of them, as we shall see, having Chinese elements in their make-up. The soft curtain to hang in front of the painting is a form not often used in Japan, where the doors of a shrine protect the sacred object from dust. 
Probably nineteenth century. This shows a trinity of Lamas, corresponding probably to one of the several Buddhist Trinities. Below are three figures belonging to the world of force and transition. This must be a late form of the Lamaistic work, possibly done by a Chinese pupil of the Thibetan priests in Peking. Thibetan pictures, until the spoil of the Peking temples made them accessible in the year 1900, have been of exceeding rarity in the west.

\section{2\%-THIBETAN ALTAR-PIECE}

Probably eighteenth century. This probably represents the same five fire-spirits known as the Godai Mio-o in the Shingon sect of Japan. Above them a Lama, a spirit of higher power, rules. It is painted chiefly in gold upon a black ground, the medium being apparently not oil, but the tempera with strong glue used in Chinese and Japanese Buddhist paintings.

\section{8-THIBETAN ALTAR-PIECE}

Probably eighteenth century. An elaborate composition of violent types. This belongs to what has vaguely been characterized by writers as "devil-worship." This title is perhaps unfair, because the power derived from the ritualistic service is supposed to be utilized for high ends by the Lama or priest. A glimpse of a Lamaistic walled temple or palace on the right is interesting. The pearly color, accented by the black blues, is very striking:

\section{9-THIBETAN ALTAR-PIECE}

Probably eighteenth century. This gives us types transitional from the violent forces of nature to the serene planes of spirit. It is surely not executed in oil, and the central figure is very much like Chinese and Mongolian types, so it seems probable that this is by a Chinese pupil of the Lamas. The coloring is very rich, though not so delicate as that of No. 2725 .

\section{0-THIBETAN ALTAR-PIECE}

Probably seventeenth century. This is the strongest and finest of these pure Thibetan paintings, in both drawing and color. It is in thick oil upon canvas. The figure in red, with several arms, seems closely related to the "Aizen Mio-o" of Japanese Buddhism, 
the "Bodhisattwa of Love." This, in appearance, is one of the violent gods, but, under reverent study and purifying discipline, it is said, appears to the devotee as identical with the pure white, spiritual form of Kuannon. The heads of children seen vaguely through the drapery are not a Japanese feature. The drawing of the dancing figure is especially fine in motion, and the composition within the boat-shaped fire-halo is strong. First of all, however, is the color, the pigment being handled with great force and purity, and the tones of fire, clouds and accessories being beautifully subdued to the intense Chinese vermilion of the central figure that seems almost as luminous as flame itself. That is, the spiritual flame clearly subordinates the material. The green and olive tones of the background make a splendid foil for the scarlet, and the similar shades in the brocade mounting add to the splendor of the effect. Altogether, this is the strongest, most unified and most beautiful Thibetan painting I have ever seen.

Possibly Mongolian. Probably eighteenth century. This is on much thinner cloth, and clearly in the Chinese style of drawing and applying color. The faces, however, and the forms of fire-halo and clouds, are such as are not found in pure old Chinese Buddhist art. Mongolian altar-pieces often stand, in this respect, between Thibetan and Chinese types. The heap of jewels which an attendant is pouring from a tiger-skin typify, probably, treasures of spiritual attainment.

In front of the silk curtains descend two long free strings, which seem as if they were used to confine the picture and covering. They may be the origin of the "wind-strings" found, as a decorative feature, on some Chinese and Japanese mountings, but here preserved in the Lamaistic temples for their primitive function.

\section{2\%32-LAMAISTIC ALTAR-PIECE}

Probably late eighteenth or early nineteenth century. Chinese. This style is almost pure Chinese Buddhist, and doubtless by a Chinese, being Thibetan or Lamaistic only in the subordinate features of the thin canvas instead of silk, and the pointed flame halo. The handling of the pigment upon the faces is specially beautiful in its gradations. 
Belonging to the same series as No. 2732. Chinese, eighteenth or nineteenth century. These represent, probably, deva, a high class of nature spirits, more powerful than man in material organization, inferior in spiritual. The color of the flame halo is especially fine.

2734-LAMAISTIC ALTAR-PIECE

Belonging to same series. Chinese eighteenth or nineteenth century. 'The green flesh here is very fine; the female figure, trodden down below, well painted. The musical instrument is the biwa, or Chinese lute, under the strings of which, in old examples, is set a band of leather elaborately painted. The design of the decorated band appears here to be of Sung type. The figures in the last three examples must be modified copies of old originals, with strong Chinese features.

\section{ANCIEN'T CHINESE PAINTINGS}

\section{5-CHINESE RELIGIOUS PAINTING}

Probably eighteenth century. 'This is one of a series of paintings representing the doings or miracles of Arhats (Japanese " Rakan"), i.e., saints in the flesh. Though they are upon coarse cloth, and with the dust-curtain in front, and so probably taken from a Lamaistic temple, I class them here as Chinese, because they are probably more or less accurate copies from an ancient Chinese set, and therefore belong in design to pure Chinese Buddhist art. The designs have perhaps descended through a long series of copies, Tang, Sung and Ming, and are of an unusual type, probably pointing back to originals of north Chinese Buddhist art, of date possibly as far back as the seventh century. This colored type of landscape dates from that time, and was probably used by the great artist of early Tang, Enriuhon. The color of the draperies is very bright and clear, the blue and green being powdered lapis lazuli and malachite.

\section{6-CHINESE PAINTING OF ARIIATS}

Probably eighteenth century. Same series as the preceding and of similar origin. Surely these designs are far more beautiful than any Chinese painter of late centuries could create. The tree forms are particularly strong and antique in conception. The turbaned attendant on the right, holding a vase, is exceptionally beautiful. 'Tle composition is well unified. 
Probably eighteenth century. This shows the hermit type of Rakan seated in a cave. The animals, monkeys and deer, stimulated by the sanctity, bring him offerings of fruits and flowers. 'The different types of trees are strongly differentiated in both drawing and color. The greenish tones of the cloud, with red and blue linings, are strange and primitive. The deer is beautifully drawn.

\section{8-CHINESE PAINTING OF ARIIAT}

Probably eighteenth century. This seems to show us a central Asian king kneeling in worship before the saint. Here the clouds have still richer coloring in pearly olives, blues and pink, which wonderfully blend with the more atmospheric blues of the distant mountains, and the more material greens of the great pine tree. The upper part of this painting thus gives us an exceptionally beautiful composition, worthy of ancient Chinese art.

\section{9-CHINESE PAINTING}

Probably Hiouentsang, the great Chinese pilgrim of the seventh century. Probably eighteenth century. Though not strictly an Arhat, Hiouentsang (Japanese "Genzo") seems to be included in this set of great priests. The tiger of the wilderness, like a tame dog, accompanies him; but the real guidance is beautifully represented by the apparition in colored light of the little Buddha, which, apparently issuing from the devotee's brain, shows how the powers of the spirit-world second the noble vows of men. The colors of the landscape are here exceptionally deep and beautiful, the blue tree on the right wonderfully contrasting with the pale green clouds. The flowers are like jewels.

\section{0-CHINESE PAINTING OF ARHAT}

Probably eighteenth century. The attendant prepares the incense for the saint's service. The coiled snakes on the right are well drawn. The great fruit tree, apparently a persimmon, is splendidly massed. The main figure is beautifully poised, quite as in fine Sung types, and holy in rapt face. The opalescent color of the water-worn rock, jade-green cloud and blossoming plum in the lower right corner are unearthly in beauty. How the coloring of these paintings makes us think of Christian tempera altarpieces of the fourteenth century, by such men as Giotto, Lorenzo Monaco, Pesellino and even Fra Angelico! 
Probably of eighteenth century. Here the Arhat holds a rat, out of whose mouth he chokes a heap of jewels. Doubtless this typifies the spiritual power which can turn even meanness and ugliness to holy uses, even sometimes making supreme salvation in unpromising soil.

\section{2-CHINESE PAINTING OF ARIIAT}

Probably eighteenth century. Here the saint has caused the apparition of the fabulous Buddhist bird, the "Hōwo" or phœnix. The distant mountains are delicately rendered.

2Y43-CIITESE PAINTING OF ARHAT

Probably eighteenth century. The power of the saint tames a tiger. The type of face and the whole drawing of the Arhat are like Sung-art. His color is finely varied and rich, the variety of the blues being noticeable.

2744-CIIITESE PAINTING OF ARHAT

Probably eighteenth century. The saint, holding up a packet of sacred scripture volumes, causes a magic light to issue from it. The color of the clouds is exceptionally fine, the pearl tints contrasting with the deep blue.

\section{2\%4-CHINESE PAINTING OF ARHAT}

Probably eighteenth century. Here the landscape exhibits new effects, the broad valley with the flowing water being a specially fine bit of ancient landscape conception, such as Enriuhon may have painted in North China. Notice how all through this series every species of tree has the drawing of its leaves clearly differentiated in form and lines of growth.

\section{6-CIIINESE PAINTING}

Probably eighteenth century. This again is not an Arhat, but a primitive Chinese rendering of a secondary saint, "Hotei," the vagabond god and friend of children. The poppy and butterfly bit in the foreground is charming. 
Probably eighteenth century. This is one of the most gorgeous in color, and dramatic in action. Out of the saint's jewel alms bowl, so thin that the thumb is seen through its crystal substance, issues a stream of jade-colored water twisting as if with life, that becomes, in its higher coils, the visible water-spirit or dragon, writhing in cloud and fire and golden lightning. The deep blue of the sky behind gives brilliant effect to the passage. The subdued olives of the high clouds at the left keep the brilliancy for the dragon. The small boy at the lower left hides his face with his sleeve, in fear of the apparition.

\section{8-CHINESE PAINTING OF ARHAT}

Probably eighteenth century. The saint has received, by miracle, a jewelled crown. This is softer and more atmospheric in its landscape background. The apparition below is of a dragon spirit, the beast, four-clawed, being splendidly drawn. For modern paintings this set is one of the best $I$ have ever seen, a fact due clearly to its combination of ancient design with the brilliancy of recent coloring. 'The execution of the originals must be still more powerful, crisp and subtle. I still feel that the type is at bottom early Tang, but perhaps modified by the introduction, in some later copy, of Sung features.

\section{ANCIENT JAPANESE PAINTINGS}

2749-LARGE PAINTING OF TIIE BUDDHIST HEAVEN OF THE JODO SECT

Seventeenth century. The design, as in all modern paintings of this subject, is taken from a great original in the eighth century. It was the monk painter, Yeishin Sozu, in the eleventh century, who probably made the modification of painting all the figures in gold. This is a work of the seventeenth century, and is most delicately executed, so much so that it seems that only the brush of Sumiyoshi Gukei, a descendant of the old Tosa school, would be capable of it. But its most remarkable quality is the beauty and restraint of its color, every tone, even the vermilion reds, being reduced to the most tender scale of harmony. The black of the platforms gives the deep tones that throw up into light the composition. This is a world analogous to the heavenly visions, also 
often done in gold, by Fra Angelico. The text, written on many borders of the painting, in gold, is of exquisite beauty and clearness. Although the Buddhist painting of Toku-gawa days cannot be said to be creative, in the sense in which the ancient art was creative, this work represents, probably, the highest rank reached by the new eclectic Buddhist painting revived under the latest dynasty of the Shoguns. The smaller designs, cutting into panels the three borders, and of still greater minuteness, are the analogous of the predella paintings on old Italian altar-pieces. The complicated architecture doubtless gives us a sense of what the great Chinese palaces of early Christian centuries were like.

\section{0-LARGE CARTOON FOR ELABORATE BUDDHIST PAINTING}

By Kano Kazunobu. Nineteenth century. Kazunobu, a late pupil of the Kano school, was an original genius who, becoming a profound Buddhist believer, dedicated his life to the painting of one hundred large pictures on silk, in most minute coloring, which he finished under the direction and advice of the learned abbot of the temple of Zozoji in: Shiba (a ward of Tokio), with whom for years he resided.

These paintings were until recent date, and perhaps still are, exhibited to the public, just inside the great gate of Shiba, by the widow of the artist, who long survived him. Dr. Anderson, the English critic, used to say of these paintings that they formed together the greatest masterpiece of the Kano school. The truth is that they are quite unlike ordinary Kano technique, and without the refinement of artists trained in the traditions of Godoshi and Ririomin; but they have the great merit of being absolutely original conceptions; not modified copies of old Chinese originals, but thought out afresh, with new imaginative conception and color. The Scripture facts which they interpret were worked out by the scholarly priest.

Now, here, for the next fow examples, we have the original cartoons in which Kazunobu sketched some of his first conceptions, which were afterward elaborated on silk into far greater minuteness and beauty. It is a pity that we have only so few of the original hundred designs. Nothing else like them exists in Chinese or Japanese art. This, and several others, are inscribed by the artist's own hand as "Studies for the paintings of the Five Hundred Rakan belonging to Zozoji, from the pen of Hogen Kazunobu." So far for this set. 
This design represents, above, the charitable deeds of the Arhats, who feed, from their grain bags, the starving inhabitants of a cave. Below, two of them expound the Scriptures, while another makes his miraculous way through a raging flood, like Moses in the Red Sea.

The pigment in these cartoons has been put on coarsely, as a mere suggestion of the color, with no attempt at transparency and purity. These are merely working drawings, kept beside the artist during his many years of detailed work. All the drawings and attitudes are original, and some of the heads are very fine. It is desirable that these cartoons should be preserved in some proper collection for the world's future study. The color here is especially fine.

\section{1-CARTOON FOR THE FIVE HUNDRED RAKAN}

Kano Kazunobu. Nineteenth century. Above, we have the miracles that appear in the Arhats' worship of a little porcelain statue of Kuannon. Below, one Arhat is about to write out a new Scripture to the dictation of the dark thoughtful figure on the lower right. Some of the Arhats are supposed, in one tradition, to have been personal pupils of the Buddha, and after his death to have written out their gospels from memory. But the subject is of much later creation, and all sorts of anachronisms are found in the many paintings of the Arhats. The artist's intention, whether correct or not, is what interests us.

\section{2-CARTOON FOR THE FIVE HUNDRED RAKAN}

Kano Kazunobu. Nineteenth century. This merely shows the daily life of the Arhats, two above bathing behind a screen, one below being shaved by another. Fortunately, in the bath episode Kazunobu has left us a bit of his original drawing, not smeared over by the opaque trial colors. In this passage his method, like Hakusai's, is first to draw his thought out in red, then to correct the faint red lines by a firmer outline of black. In the final painting this outline would be still further refined, and left as a delicately modelled line against which the filling of the transparent colors would exactly play. In these cartoons the original lines have often been half blotted by the thick staining color which he constantly used. The faces of the two boy attendants in the middle distance are very strong. But the outline faces and bodies of the bathers show Kazunobu's real drawing. The attitude of the boy who holds the towel is very fine. 
Kano Kazunobu. Nineteenth century. What the boys are preparing below, to the Arhat's order, is possibly incense; the materials, gums and fragrant woods, being ground in a mortar. In the distant portion an Arhat is preaching. On the right one upbraids, and prays for, a hunter who has slain an antelope. The color of the lower saint's robe is beautifully suggested in its greens and purples. The composition of the main figures is dignified.

\section{4-CARTOON FOR FIVE HUNDRED ARHATS}

Kano Kazunobu. Nineteenth century. The mountain valley on the right is strongly drawn, where, to the order of the Arhat on the cliff, two workmen set a guide-post to mark the way where the road diverges, by a bridge, across the chasm. On the left, a scribe writes the direction on a similar post. Below, three Arhats are disputing as to the meaning of knotty passages in Scripture, while three little acolytes at the bottom are kept busy, just like modern clerks with us, looking up references in the texts. The saint at the red desk seems about to write, and the one with the wand to refer to his personal experiences. So possibly this is not so much of a dispute as the compilation of a scripture, or a comment upon one, from various sources, personal and recorded. The attitudes are quite dramatic. The composition is full and rich; the scribes at the bottom full of genial humor.

\section{5-CARTOON FOR FIVE HUNDRED ARHATS}

Kano Kazunobu. Nineteenth century. Several scenes are combined here, the lower of which are obscure in meaning. But above, one can clearly see that a saint's will, combined with the power of exposed Scripture, is driving out from the pavilion a crowd of devils. The head of the man with the feather duster is remarkably fine.

\section{6-CARTOON FOR THE FIVE HUNDRED RAKAN}

Kano Kazunobu. Nineteenth century. This also is obscure, though above, one Arhat seems to be ministering to a prostrate traveller. A boy who has been acting as scribe yawns below. The Arhat on the right blows a conch shell. 


\section{SECULAR PAINTINGS}

2758-PAIR OF PAINTINGS OF MONKEYS

School of Sosen. Nineteenth century.

2759-TWO MONKEYS ON A ROCK, WITH SPRAY OF BAMBOO

By Sosen. Eighteenth century. This is a fine genuine specimen of Sosen's middle manner, the handling of the ink and accessories being particularly crisp and strong.

2760-GROUP OF MONKEYS BY A STREAM

No signature. School of Sosen. Nineteenth century.

2761-MONKEY ON A CYPRESS BRANCH

By Toyohiko. Eighteenth century. Was one of the strongest of the second generation of the Shijo school, who came under the influence of Okio. His personal teacher was Goshun, and his most famous pupil Bunrin.

2762-MONKEY ON A DEER

School of Sosen. Nineteenth century.

2763-MONKEYS ON A ROCK

School of Kano Sansetsu. Seventeenth century.

2764-MONKEYS LOOKING AT WATERFALL

School of Sosen. Nineteenth century.

2765-MONKEYS ON A ROCK

By Donshu. Nineteenth century. This is very rough, but Donshu was a strange impressionist, whose work grows out of the school of Goshun, of the Shijo movement.

2766-MONKEY ON A CHESTNUT BRANCH

By Sosen. Eighteenth century. Here Sosen has used an unusual character for "Sen," in writing his name. This is a fine sample of Sosen's roughest style of work. 
By Sosen. Eighteenth century. This is a fine, genuine specimen, in beautiful, broadly executed grays, of the middle period.

2168-GROUP OF MONKEYS

By Sosen. Eighteenth century. This is a good example of Sosen's latest manner.

2769-MONKEYS PAINTED ON SILK AND MOUNTED ON A PANEL

By Sosen. Nineteenth century. This is a genuine specimen, but the tone has been somewhat lost in the washing.

2\%O-THE ANIMALS OF THE ZODIAC

By Kano Sosen. Eighteenth century. This artist has no relation to the Shijo artist, Mori Sosen, who painted the preceding monkeys. He belonged to a side branch of the Kano school, who for 400 years were court painters to the Shogun and the daimios.

2'Y71-TIGER ON ROCK

By Renzan. Nineteenth century. Dated 1832. This is a genuine work by the pupil and adopted son of the great Kioto animal painter, Ganku.

\section{4'T-BADGER}

By Raisho. Nineteenth century. Raisho was one of the third generation of artists of the Shijo school, and celebrated in Kioto about 1840 .

\section{Y'3-THE ANIMALS OF THE ZODIAC}

By Rosetsu. Nineteenth century. Rosetsu was one of the most original pupils of Okio, at the end of the eighteenth century. His work has always some charm of humor. The dragons are especially fine.

\section{7\%4-TWO DRAWINGS}

By Hoyen. Nineteenth century. This artist is not the famous Nishiyama Hoyen of Osaka, but a lesser man whose work lies between the Shijo and Nagasaki schools. 
27\%5-TIGER IN WIND

School of Ganku. Doubtless some inferior artist of the Ganku tradition, but an unknown man.

2Y76-DEER ON THE MOUNTAINS

By Shuki. Nineteenth century. Shuki was a late artist of the Nagasaki school founded by the Chinese Nanping. His work is not very strong, but always choice.

2Yyy-DEER IN RAIN

By Sosen. Eighteenth century. Sosen not only painted monkeys, but all animals with equal excellence. This is in a late manner, and a characteristic specimen.

2UTS-TIGER IN RAIN

By Gantai. Nineteenth century. Gantai was the son of Ganku. Works of this Shijo school are now rare to find, even in Japan.

2Yr9-DRAGON IN CLOUD

Modified school of Shijo. Nineteenth century.

2780-DRAGON IN CLOUD

By Kano Isen. Nineteenth century. Isen was the. twelfth generation of the official court painters to the Shoguns. He was the son of Yosen, and the father of Seisen.

2781-DRAGON IN CLOUD

By Koki. Nineteenth century. This a very fine piece by an artist who probably studied directly under the Shijo founder, Okio. Its composition and lines of motion are extremely grand. I consider it an exceptionally fine example of the modern Kioto school about 1810.

2782-DRAGON IN CLOUD

By Kano Seisen. Nineteenth century. Seisen was the thirteenth generation of the Kano court painters, who passed down their office from father to son. 
By Wunkin. Nineteenth century. Wunkin, the pupil and sonin-law of Shuki, was the last of the Nagasaki school in Yedo, dying in 1879. This is an early work of his, done before he became paralyzed by painting a dragon, for three days and nights without rest, on the large ceiling of a temple. I knew him personally. This is a fine piece.

2484-A KIRIN

By Genami. Late nineteenth century. This artist is almost unknown, but worked apparently under Shijo influence.

2\%8j-DRAGON IN CLOUD

By Kano Isen. Nineteenth century. This seems to be a companion to No. $2 \% 80$.

2786-DRAGON IN CLOUD

By Kano Seisen. Nineteenth century. Probably a companion to No. $2 \% 82$.

278\%-MALE KIRIN

By Genami. Nineteenth century. This is a companion to No. 2784.

2788-CHINESE LADIES AT SILKWORM CULTURE

By Soga Shohaku. Eighteenth century. Shohaku was an odd genius, who often did very powerful work. This seems to be a more delicate specimen than usual. The green cloth of the mounting is especially beautiful.

2789-DANCING SAKE GOD

By a Kano artist descended from Yasunobu. Eighteenth century. The embroidery on the paper mounting is beautiful.

Copy from Cho Densu. The original would be of fifteenth century. 
2791-TWO WILD GEESE

By Kano Utanosuke. Sixteenth century. This is a very fine example of the second generation of the Kano school, by the brother of Motonobu, whose seal has been here later affixed. It is a typical Utanosuke. The mounting is exceptionally harmonious.

\section{2-TWO FAGGOT WOMEN OF KIOTO}

By Joriu. Nineteenth century. Joriu was a female artist, third generation in descent from Okio of the Shijo school.

\section{3-FUKUROKUJU}

By Seiki. Nineteenth century. Seiki is also third generation of the Shijo school, being a pupil of Keibun.

2794-HEAD OF DARUMA

By Nammei. Nineteenth century. Nammei is affiliated to the Nagasaki school, and worked at Yedo until about 1880.

\section{5-SUBJECT OF THE JINDAI PERIOD}

By Hoyen. Nineteenth century. This is not Nishiyama Hoyen. The painting of ancient historical subjects, from Kojiki or other Shinto legend, was probably begun by Yeitaku, about $18 \% 0$. Hoyen probably took the style from him. The rocks and trees are strongly rendered.

\section{6-SUBJECT OF THE JINDAI PERIOD}

By Hoyen. Nineteenth century. This is still more like Yeitaku, and very powerful. The action is dramatic, and the trees are especially fine.

\section{7-SUBJECT OF THE JINDAI PERIOD}

The Sun Goddess emerging from her cave. By Hoyen. Nineteenth century. These last three seem to form a single series, though with varied mounting.

By Kano Isen. Nineteenth century. This is a beautiful example. of Isen, in his later manner. 
Copy from Kano Tanyu. The cloth is beautiful and rich.

2800-SHOKI

By Yamada Doan. Sixteenth century. Doan was one of the great contemporaries of Kano Motonobu. This is a very vigorous painting of the Ashikaga period, done with free flowing line. The ink is beautifully tinted, and heightened with passages of color.

2801-TWO SMALL STUDIES

By Kano Iben. Nineteenth century.

2802-SENNIN

Copy from Kano Motonobu.

2803-JAPANESE WARRIOR

By Tosa Mitsunari. Eighteenth century. This is the revived eclectic school of Tosa.

2804-HEAD OF DARUMA

By Kano Naonobu. Seventeenth century.

2805-LANDSCAPE

School of Sesshu. Sixteenth century.

2806-TWO STUDIES

By Kano Isen and Seisen. Nineteenth century. These are copies or imitations of the Chinese Mokkei, and the Chinese Danshidzui, respectively.

280\%-CHINESE LANDSCAPE

By Bunrin. Nineteenth century. Bunrin, in its third generation, is one of the greatest landscape painters of the Shijo school.

2808- $B A M B O O$

Kano school. Fighteenth century. 
2809-SNOW LANDSCAPE IN CHINA

By Nikkwa. Nineteenth century. Nikkwa is a pupil of Toyohiko, and much like his fellow pupil, Bunrin.

2810-THATCHED ROOF

By Yosai. Nineteenth century.

2811-LANDSCAPE IN RAIN

By Kano Isen. Nineteenth century.

2812-FISHES

By Kiitsu. Nineteenth century. Kiitsu is descended from the Korin school, being a pupil of Hoitsu.

2819-FISH AND WATERFALL

By Kano Isen. Nineteenth century.

2814-FISH

Kano school. Nineteenth century.

2815-LEAPING FISH

Nineteenth century. Evidently by some little-known pupil of

Okio, but a good painting.

2816-FISH AND KINGFISHER

By Bunrin. Nineteenth century. Bunrin is the teacher of Bairei.

2817-TWO PAINTINGS OF FISH

By Kano Yosen. Eighteenth century. These are fine examples of the eleventh patriarch of the court artists, father of Isen.

2818-SMALL FISH AND GRASS

School of Okio. Nineteenth century.

2819-BAMBOO AND BLACKBIRD

Kano school. Eighteenth century. 
2S20-MISTY LANDSCAPE

By Chikudo. Nineteenth century.

2821-PHEASANT AND CHERRY TREE

Nagasaki school. Nineteenth century.

2822-WILD GOOSE AND GRASSES

School of Sesshu.

2823-WILD PLUM TREE

Modern Chinese school. Nineteenth century.

2824-SPARROWS AND JAR

By Kano Tsunenobu. Seventeenth century. Tsunenobu is the seventh Kano patriarch.

2825-STORKS AND BAMBOO

By Kano Yeisen. Eighteenth century. Yeisen is the tenth Kano patriarch.

2826-WILD GOOSE AND GRASS

By Kano Isen. Nineteenth century. Of Isen's middle period.

2827-FALCON ON TREE

School of Chokuan. Seventeenth century.

2828-WILD GOOSE

By Gozan. Shijo school. Nineteenth century.

2829-SWALLOWS ON CHERRY BRANCH IN SHOWER

By Kano Sosen Akinobu. Eighteenth century. This is quite an original work, showing a somewhat heterodox Kano style.

2830-BLACK BIRD ON FLOWERING TREE

By Ganku. Eighteenth century. Ganku, the founder of the Kishi branch of the realistic movement in Kioto, has the most powerful and broad execution of the Shijo school. 
2831-HERONS FLYING

By Onishi Keisai. Nineteenth century. Keisai, the fourth generation of the Nagasaki school, was teacher of Shuki.

2832-FUYO FLOWERS

Late nineteenth century.

2839-WHITE HERONS

Nagasaki school. Eighteenth century. Signed "Nanping," the founder, and possibly a copy from him.

2834-THREE BLACKBIRDS

School of Sesshu. Sixteenth century.

2835-SNIPE AND GRASSES

By Kano Yeigaku. Nineteenth century. This artist belonged to a Kioto line, descended from Sansetsu.

2836-STORKS AND PINE

By Kano Isen. Nineteenth century. The pine has been retouched.

2837-EAGLE ON ROCK

By Bun-o. Nineteenth century. Bun-o was a son of Tani Buncho.

2838-ONE HUNDRED STORKS

Kano school. Eighteenth century.

2839-TWO SMALL SKETCHES

By Hoyen. Nineteenth century. Same set as No. 2775.

2840-BIRD SINGING ON PLUM TREE IN SNOW

By Kano Yosen. Eighteenth century. This is an exceptionally fine piece by Yosen, the eleventh Kano chief, reminding one of the strong work by his ancestor, Naonobu.

2841-THREE GEESE IN CIRCLE

Copy from Kano Motonobu. Eighteenth century. 
2842-FLOWER PAINTING

Late nineteenth century.

2843-STORKS AND PINE

By Tansaku. Eighteenth century. This artist belongs to a branch of the Kano school. A strong piece.

2844-CHERRY BLOSSOMS

By Onishi Keisai. Nineteenth century. Nagasaki school.

2845-LOTOS LEAVES

Copy of Kano Tanyu.

2846-WHITE HAWK AND PINE

School of Buncho.

2847-FALCON ON PERCH

Kano school. Nineteenth century.

2848-BAMBOO

By Kano Isen. Nineteenth century.

2849-BIRD AND BAMBOO

Genuine Chinese of Ming.

2850-WILD GEESE AND GRASSES

By Hosai. Chinese of eighteenth century. This artist visited, and taught in, Japan.

2851-QUAIL AND FLOWERS

Copy from Tosa Mitsuoki.

2852-CHERRY BRANCH AND FISH

By Gisho. Nineteenth century. Shijo school. 
2853-PEONY

By Chinese artist of Ming. Has been retouched.

2854-WATERF ALL

Kano school. Eighteenth century.

2855-EAGLE AND PINE

By Kano Chikanobu. Eighteenth century. Chikanobu, son of Tsunenebu, was the ninth patriarch of the Kanos. An exceptionally strong specimen of this artist.

2856-SWIMMING DUCKS

Shijo school. Nineteenth century.

2857-FLOWERS AND BIRD

By Kiitsu. Nineteenth century.

2858-GRASSHOPPER AND RICE

By Keibun. Eighteenth century. Keibun was one of the great pupils of Okio and Goshun.

2859-FUYO FLOWERS AND GEESE

School of Nagasaki. Nineteenth century. The name of Nanping

has been affixed, but I judge this to be a fine original by Shuki.

2860-WILD DUCKS AND GRASSES

By Kano Tanyu. Seventeenth century. This is a fine specimen of this artist, in his latest manner, at the age of 70 .

2861-SET OF TWO PAINTINGS-WILD DUCKS

By Kano Tanyu. Seventeenth century. Age $6 \%$.

2862-THREE MAKIMONO

Copy of an old Tosa painting.

2863-MAKIMONO

Eighteenth century. 
2864-MAKIMONO

Ghosts. Eighteenth century.

2865-MAKIMONO

School of Kano Yasunobu. Eighteenth century.

2866-MAKIMONO

Prints by Nishikama Sukeye. Eighteenth century.

2867-MAKIMONO

Destruction of a ship. Nineteenth century.

2868-KAKEMONO

Portraits of Kwanu and Kōmei, two great Chinese generals, cm. broidered in gold and silk threads. By Yen Hō Shun at the age of fifty.

2869-LARGE KAKEMONO

Embroidered design of Chinese palaces and of garden sceue, framed with red borders with embroidered dragons. Originally made for a complimentary gift. Mountings are of Chinese silk brocades. Date, Ch'ien-lung period. 1736.

28\%0-KAKEMONO

Embroidered design of Chinese landscape; two figures and pine tree in the foreground; royal pleasure boat in centre and palace buildings and mountain views in the background. Specimen of very fine old Chinese needlework.

28\%1-KAKEMONO

Embroidered design of flower vase with flower and water kettle in natural colored silks on a black satin background. After Yūhō, a Chinese artist. 
Embroidered design of three demons on a stand, and a flower. basket, in skilful workmanship, on black satin background; silk brocade mountings. Seal mark of Yūhō.

\section{3-KAKEMONO}

Subject: " Death of Buddha," in gold and silk thread embroidery on a dark ground. Groups of mourning attendants, surrounding the Buddha, minutely rendered in various colored silks. White silk embroidered mounting.

\section{4-UNMOUNTED KAKEMONO}

Allegorical subject, woven in silk. Gathering of Chinese sages and attendants, boating scene and cloud forms. Beautiful workmanship of the seventeenth century.

Height, 73 inches; width, 37 inches.

\section{5-KAKEMONO}

Silk embroidery. Two birds perched on a branch, embroidered in light blues, yellows, purples and whites on a brown background. Brocade mountings. Chinese specimen.

\section{6-PAIR KAKEMONOS}

Embroidered designs of Chinese dignitary and his attendants, under trees. Chinese workmanship. Seventeenth century.

\section{8\%7-SMALL KAKEMONO}

Subject: Indian Buddha, in seated attitude, woven in silks of various colors on a blue ground. Mounted with gold brocaded red silk. Seventeenth century.

\section{8-PANEL}

Decoration of a view of a poultry farm, finely painted on silk in colors by Okio. Signed.

$$
\text { Height, 141/2 inches; width, 571/2 inches. }
$$

\section{9-PANEL}

View of a boating scene: three boats full of excursionists; minutely painted in colors on silk. 



\title{
THIRD EVENING'S SALE
}

\author{
TUESDAY, JANUARY 23D, 1906
}

\section{AT THE AMERICAN ART GALLERIES}

BEGINNING AT 8 o'CLOCK

\section{RARE AND VALUABLE ANTIQUE CHINESE AND JAP- ANESE BOOKS ON ART AND INDUSTRIES AND ALBUMS OF PAINTING AND PHOTOGRAPHS}

2880-SMALL ALBUM

Containing twenty photographic views of famous temples of old Japan.

2881-SMALL ALBUM

Containing thirty-two photographic views of celebrated sculptors in wood in the Temple of Nara.

2882-JAPANESE ALBUM

Containing thirty-five paintings on silk of landscapes, figure and floral subjects, by artists of the various schools of the nineteenth century.

2883-JAPANESE ALBUM

Containing twenty paintings on silk of mountain scenery, flowers, birds and figure, by artists of the nineteenth century.

2884-JAPANESE ALBUM

Containing twenty paintings on silk. Birds, fish, mountain scenery and legendary subjects by Baïrei and others. 
Containing forty Japanese paintings on silk. Landscapes, flowers, birds and figure subjects by Kijoto artists of various schools of the nineteenth century.

\section{6-ALBUM}

Containing nine finely executed sketches in India ink. Landscapes, animals and garden scenes by Japanese artists of the nineteenth century.

2887-ALBUM

Containing seventeen Japanese paintings on silk. Landscape, river and mountain scenery and figure subjects by Oboūn, Kaguétoshi, Bei-San, Tashiou and Takôo. About 1850.

2888-ALBUM

Containing twelve Japanese paintings on silk of Buddhist priests.

2889-TWO ALBUMS

Each containing twelve landscape and river views finely executed in India ink by Un-Kōku.

2890-ALBUM

Containing twenty-six prints by Hokusai Utamara, Hirishigo and others.

2891-LARGE ALBUM

Containing fifty-six prints by Hokusai Utamara and others, and numerous specimens of old Japanese textiles.

2892-ALBUM

Containing fifty-four photographs of Japanese ceremonial, domestic and industrial scenes.

2893-TWO ALBUMS

Containing sixty-four photographic views of famous temples, carvings and scenery at Nikko. 
Containing eight pictures, finely executed in needlework in brilliant colors of silk on cream-white satin, principally river views, by a Chinese artist.

2895-LARGE ALBUM

Containing twenty-six Japanese paintings on silk. Famous scenes in and near Kyoto by artists of the Shijo school. About 1880.

2896-ALBUM

Containing twelve paintings in water-color of various boats, by a Chinese artist.

2897—SKETCHES AND STUDIES

Seventy specimens by Japanese artists and students, principally of the modern Kano school.

2898- $A L B U M$

Containing seven beautifully executed designs of imperial robes. Executed in colors on silk by a Chinese artist.

2899-FOUR CHINESE WATER COLORS

Landscapes and water views by So jü shō.

2900-ALBUM

Containing sixty-two water-color paintings by Chinese artists, illustrating the trades and customs of China.

2901-THREE JAPANESE BOOKS

"Ko kon Kaji mei haya midashi," "Jinko fu riakü," and "Kotō Kaji Meijin," by Sekisui donin. Works on sword blades and old metál-work.

2902-ENGLISH AND CHINESE DICTIONARY

From W. H. Medhurst and other authors and photo-lithographed from the Kwong Ki Ohius edition, Shanghai. 1882.

2903-SETSU BUN KO RIU HO

A dictionary of ancient Chinese characters; in two parts. 
2904-GOSHA IN FU

A dictionary of the Chinese language by the Rev. R. Morrison, D.D., Shanghai. 1879.

2905-CATALOGUE

Of the contents of the Imperial Palace, thirteenth year of ChiaChing, 1809. Being a catalogue of the different rooms of the palace, comprising all the contents, furniture, curios, works of art, books, etc.

2906-"KIN KO KAN TEI HIKKEI"

A book on Japanese sword ornaments. Dated 3rd Bunsei (1820).

2 volumes.

2907-BOOK ON HERALDRY

Japanese. 3 volumes.

2908-JAPANESE ALBUM

"Sa Shiū Kin gin Saisei Zendsu." A series of water-color paintings illustrating the gold and silver mining operations on the island of Sadō, Japan.

2909-“TODO RCKI DAI SHU GUN YEN KAKU CHIDSU"

A Chinese atlas, with colored plates. Ch'ien-lung period.

2910-BOOK ON JAPANESE TEA CEREMONIES

"Sen-cha dsu shiki." Colored plates.

2911-"DAI KIN KO DO"

Illustrated book on working in metals. Old Japanese.

2912-BOOK ON JAPANESE COSTUMES

"Shö-soku dsu shiki." Profusely illustrated. 2 volumes.

2913-“BUTSU ZO DSU I"

Encyclopedia on Buddhistic subjects. Profusely illustrąted. 1796. 
2914-JAPANESE BOOK OF DESIGNS

"Ga yū man roku." Containing designs for textiles, and showing manner of tying knots. By Oyeda Riūhō. Dated 1763. 7 parts.

2915-"SEI KIOKU RUI SAN"

A Japanese book on music and musical instruments. By Haku setsudo Gekkinshi. Illustrator, Shōsai Settei. Published 1843.

2916-JAPANESE BOOK

Antiquities and designs by Kwayei Manroku. Text by Nishimura. Illustrations by Ki-itsu. Date, 1820. 2 volumes.

2917—“ONNA CHO HO KI"

Book on costumes and occupations of women. By Takai Ranzan.

Illustrated by Yeijo, daughter of Hokusai. Dated, 4th year of Ko Kwua (1847).

2918-MAKIYE DAIZEN

Book on lacquer designs. Japanese original edition of 1759. By Hokkio Shunsen.

2919-“KIU KO DSU FU"

Book on writers' materials. Japanese. Profusely illustrated with colored and black and white illustrations by Narushima Shichoku. Dated $181 \%$.

\section{0- "SAN REI DSU"}

Book on ancient Chinese ceremonies, costumes, utensils, etc., used therein. Profusely illustrated by Kikuchi Bushiu. Date, 1761. 3 parts.

2921-"NAMPO SHU GEN"

Ancient matters, notes, anecdotes and derivations of various names. By Shoku-sanjin. About 1850. 2 volumes.

2922—“KOSHO KU DSU-KI"

Book on Japanese rice and silk culture. Profusely illustrated. Published by Sojün dō, Kioto, 1672. 2 volumes. 
2923- "SHO KU BA KI"

Japanese book on horses and their equipment. Illustrated with colored plates. By Arai Kō Ren. 185\%. 2 volumes.

2924-"JO KUN HIA KUNIN ISSHU”

Book on Japanese poetry. Profusely illustrated. Fine impression.

By Fujimaki Yotan. Date, 1859.

2925-BOOK OF PRINTS

Containing 38 specimens by Kunasada and pupils. About 1840.

2926-"BUNSCKI DO CHOSATSU SOSHI KITSU KIN DSU”

Book on bronzes. A Japanese reprint. Taken from the Chinese of Tao-Kuang period. By Kitamma Shirobei, Kioto. 1882. 2 volumes in folio.

2927-"TO-TO MEI SHO DSU YE"

Famous palaces, their contents and ceremonial subjects. A Japanese reprint of an ancient Chinese work by Okada Yushio. Illustrations by Oka Bunki and Ohara Minsei. 1805. 6 parts in folio.

2928- "BAI YEN KI SHO”

Japanese antiquities. By Morikawa Seiko. Dated 1828.

2929—“SHO KO DSU ROKU”

Japanese early antiquarian relics. By Yokoyama Yusei. Date, 1875 .

2930—“KWAN KO ZATSU JO”

Japanese antiques. Colored and black and white illustrations by

Hoida Tadatomo. 1841.

2931-“HATSU-UN YOKO"

Japanese antiques. Rare edition by Matsu-ura Hiroshi. Dated 1882. 2 volumes.

2932- "NARA NO RAKU YO"

Early Japanese antiquarian relics. Colored and black and white illustrations. Published at Imperial Japanese Art Museum, Tokio, 1881. 
2933- "KO CHIN IKEBANA KAGAMI"

Japanese arrangement of flowers. Profusely illustrated by Aizawa

Banshü. 1829-1840. 2 vols.

2934- "BAMPO ZENSHO"

Encyclopædia of Japanese arts and crafts, with illustrations and seal marks. Date, 168\%. 13 parts.

2935-"SEI ZOKU KI BUN"

Chinese architecture, costumes, implements and utensils. Profusely illustrated by Ishizaki Yushi and Yasuda Sokiô. Dated 1799. 6 parts.

2936-"KIN TEI SEN ROKU"

Ancient Chinese coins. Text and illustrations. 8 parts in folio.

2997-"SHO SAN RIM DO SHO GWA BUNPO DSU ROKU"

Encyclopædia on Chinese art. By Sawa Tokuki and Yamanouchi

Shiū. Illustrated by Gain and Sa iu. Dated 1854. 10 parts.

2938- "SAN KAI MEISAN DSI KAI"

Japanese fisheries. Profusely illustrated by Hokkio Kwangetsu.

Dated 1799. 5 parts.

2939-"ITSUKUSHIMA YEMA KAGAMI"

Votive panels in Japanese temples. By Chitose yen tai jin. Illustrations by Watanabé Taigaku. Dated $184 \%$.

2940-"KIOSAI GWA DAN"

Japanese pictorial designs. Black and white and tinted illustra-

tions. By Uriū Seiwa and dated 188\%. 4 parts in folio.

2941-DICTIONARY OF ANCIENT CHINESE CHARACTERS

By Joshōkei. Date, 1875. 8 parts in folio.

2942- "KUMMO DSU IDAI SEI"

Japanese encyclopædia. Profusely illustrated by Shimo Kawabe

Zissuishi. Published 1788 by Kiũ yei do, Kioto. 5 parts in folio. 
2943-CHINESE ENCYCLOP EDIA

By Hei Jū Senan. Profusely illustrated by Tachibana Yusetsu. Date, 1\%25. 15 parts.

294:- "SO-KEN KISHO"

Fine arts of Japan. Workers on lacquers, sword guards and carvings, with their signatures. Profusely illustrated. By Inaba Shinyemon. 1\%80. $\%$ parts.

\section{5-“KINKO KANTEI HIKKEI"}

Japanese sword ornaments. Profusely illustrated by Han Kwan and Noda Seimei. Dated 1822. 2 parts.

\section{6-BUYO BEN RIAKU}

Encyclopædia of military tactics and equipment. By Kino-Shita

Gishun. Illustrated by Jen i sai. Dated 1712.

2947-DICTIONARY OF ANCIENT CHINESE CHARACTERS

By Taiko Shükin. 17r2. Very rare edition. 8 parts in folio.

\section{8- "ITSUKUSHIMA DSU KAI"}

Japanese guide-book. Profusely illustrated with views of celebrated places, famous palaces and historical events. By Kiyoshi Okada. Dated 1842. 10 parts.

2949-“KWAN-DO-DZU-SETSU"

A most valuable work on Japanese pottery. Original text and lithographs by the antiquarian Ninagawa Noritané. $r$ parts in Japanese and 5 pamphlets of text in French:

\section{0-“HSI CHING KU CHIEN"}

A Chinese work illustrating collections of old bronzes and inscriptions thereon. 24 parts.

2951-“CHIN-SO" AND "CHIN-CHI-SO"

Inscriptions on stone and metal-work of ancient Chinese. By Emperor Tao-Kuang. 2 volumes. 
By Shiriōba. Date, 1821. Bound in half morocco gilt. 2 volumes.

2958-“PO KU T'OU $L U$ "

The earliest book made by a Chinese antiquarian on Chinese bronzes. Ming period. 48 parts in 8 volumes.

2954-"PO KU T"OU"

Original manuscript of this rare work on ancient Chinese bronzes, Japanese edition. 2 parts in folio.

NoTE.-The above was originally the property of a Mr. Murakama, who parted with it to Yeizedo Shujin, from whom it was obtained by M. Hayashi for the late Mr. Heber R. Bishop.

2955-“SHU KO JIS SHU”

Japanese antiquities and inscriptions.

2956-JAPANESE ENCYCLOPADIA AND COMPENDIUM OF CHINESE KNOWLEDGE

By Kō shū ō (Chinese). Published Wan-li, 2nd year (1575),

Complete in 56 parts.

2957—“KAK KWA"

A Japanese art journal. Parts 1 to 48 in folios.

2958-" $K U Y U T$ T'OU $P U "$

The famous antiquarian book on Chinese jades. Complete in 24 parts. Ch'ien-lung period.

2959- "KU YU T'OU PU"

A work on ancient Chinese jades. A reprint of the original work.

Complete in 8 parts.

2960-CHINESE DICTIONARY

The most elaborate dictionary made. By Emperor K'ang hsi, issued in the 55th year of his reign. Complete in 40 parts. 


\title{
ETCHINGS AND ENGRAVINGS
}

\author{
ALMA-TADEMA， LAURENZ
}

Born in West Friesland, Holland, in 1836. Pupil of Leys. Elected a Royal Academician in 1879.

"In their technical qualities these pictures are no less admirable than for their learning and beautiful conception."

2961-UNDER BLUE SYRIAN SKIES (OP. CCCLXIII)

Proof photogravure, on India paper. Signed by the artist. Gold frame.

\section{BRUNET-DEBAINES, A.}

"Few etchers of the modern French school have produced such uniformly good work."-P. G. Hamerton, "Etching and Etchers," p. 229.

2962-A DANCE IN ARCADIA

After the painting by Corot. Signed artist's proof, on vellum. Gold frame.

\section{COURTRY, CHARLES JEAN LOUIS}

Pupil of Gaucherel and Flameng. A Chevalier of the Legion of Honor since 1881.

“C'est un graveur de tempérament, qui fait honneur à l'eau-forte."-Beraldi. 2963-A NORMANDY PASTORAL

Signed remarque proof.

\section{DORÉ, GUSTAVE}

Born at Strasbourg in 1833. Died in 1883. His illustrations for Don Quixote, the "Inferno" of Dante, the Bible, the poems of Tennyson, the works of Rabelais, the Legend of the Wandering Jew, "Les Contes Drôlatiques" of Balzac, etc., etc., have made his name world-famous.

"A man of extraordinary endowment . . . gifted with marvellous fertility of imagination and wonderful facility of execution." 
Engraved by H. Bourne. Proof on India paper. Signed by painter and engraver. Bronze frame.

"And it came to pass, that at midnight the Lord smote all the firstborn in the land of Egypt, from the firstborn of Pharaoh that sat on his throne unto the firstborn of the captive that was in the dungeon; and all the firstborn of cattle."-The Second Book of Moses, called Exodus, chap. 12, verse 29.

\section{5-THE BRAZEN SERPENT}

Engraved by Alphonse François. Proof on India paper. Signed by painter and engraver. Bronze frame.

" And the people spake against God and against Moses. . . . And the Lord sent fiery serpents among the people, and they bit the people; and much people of Israel died. . . . And Moses prayed for the people. And the Lord said unto Moses, Make thee a fiery serpent, and set it upon a pole: and it shall come to pass, that every one that is bitten, when he looketh upon it, shall live."-The Fourth Book of Moses, called Numbers, chap. 21, verses 5-8.

\section{6t-THE BATTLE OF ASCALON}

Engraved by H. Bourne. Proof on India paper. Signed by painter and engraver. Bronze frame.

Ascalon, a town of Palestine, one of the "fenced cities" of the Philistines, is on the shore of the Mediterranean, about twelve miles north of Gaza. On the plains of Ascalon a celebrated battle was fought between the Crusaders under Godfrey de Bouillon and the Saracens under the Vizier of Egypt.

2967-MASSACRE OF THE INNOCENTS

Engraved by Henri Godfrey. Proof on India paper. Signed by painter and engraver. Bronze frame.

"Then Herod . . . was exceeding wroth, and sent forth, and slew all the children that were in Bethlehem, and in all the coasts thereof, from two years old and under."-The Gospel according to St. Matthew, chap. 2, verse 16.

2968-CHRIST'S ENTRY INTO JERUSALEM

Engraved by Alp. François. Proof on India paper. Signed by painter and engraver. Bronze frame.

2969-CHRIST BEFORE CAIAPHAS

Engraved by Louis Godfrey. Proof on India paper. Signed by painter and engraver. Bronze frame.

"And they that had laid hold on Jesus led him away to Caiaphas the high priest, where the scribes and elders were assembled."-St. Matthew, chap. 26, verse 57. 
Engraved by H. Bourne. Proof on India paper. Signed by painter and engraver. Bronze frame.

2971-HAIL! KING OF THE JEWS!

Proof on India paper. Unsigned. Oak and bronze frame.

2972_" ECCE HOMO"

Engraved by A. Huot. Signed artist's proof, on India paper. Bronze frame.

29\%?-THE NIGHT OF THE CRUCIFIXION

Engraved by H. Bourne. Proof on India paper. Signed by painter and engraver. Bronze frame.

2974-THE ASCENSION

Engraved by Gustave Biot. Proof on India paper. Signed by painter and engraver. Bronze frame.

2975-THE DREAM OF PILATE'S WIFE

Engraved by Alp. François. Proof on India paper. Signed by painter and etcher. Bronze frame.

2976-CHRISTIAN MARTYRS IN THE COLISEUM

Engraved by H. Bourne. Proof on India paper. Signed by painter and engraver. Bronze frame.

"Very impressive, also, are such wonderful compositions as his "Martyrs in the Coliseum" and "The Dream of Pilate's Wife." The imagination displayed, the massing of chiaroscuro, the rush and movement of grouping vast multitudes, and the moral impressiveness of the ideas conveyed are certainly indicative of immense reserve power." $-S . G . W$. Benjamin, "Contemporary Art in Europe."

2977-THE TRIUMPH OF CHRISTIANITY OVER PAGANISM

Engraved by C. W. Sharpe. Proof on India paper. Signed by painter and engraver. Bronze frame.

2978-SOLDIERS OF THE CROSS

Engraved by H. Bourne. Proof on India paper. Signed by painter and engraver. Bronze frame. 
Engraved by John Saddler. Signed artist's proof, on India paper.

Oak and bronze frame.

2980-DAY DREAMS

Engraved by Louis Godfrey. Proof on India paper. Signed by painter and engraver. Oak and bronze frame.

\section{1-THE NEOPHYTE}

Etched by Doré from his own painting. (The etching was exhibited in the Salon, 187\%.) Signed artist's proof, on India paper. Bronze frame.

"The best pictures of Doré that I have seen are the 'Famille du Saltimbanque' and 'Le Néophyte.' This last picture was exhibited in the Salon of 1868, and represented a young monk seated among his brethren, and visibly new to his position. The conception of the subject was strikingly vivid, and the execution vigorous and frank."-P. G. Hamerton, "Painting in France."

"His 'Néophyte,' for example . . . is one of the most tremendous invectives against the conventual system which has been seen since the days of Savonarola."-S. G.W. Benjamin, "Contemporary Art in Europe."

2982-THE VINE

Engraved by H. Bourne. Signed artist's proof, on India paper. Bronze frame.

2983-LE TAPIS VERT', '̀ BADEN-BADEN

Engraved by W. Ridgway. Proof on India paper. Signed by painter and engraver. Bronze frame.

2984-ANDROMED A

Engraved by H. Bourne. Proof on India paper. Signed by painter and engraver. Bronze frame.

2985-PAOLO AND FRANCESCA DA RIMINI

Proof on India paper. Signed by Doré. Bronze frame.

"His best picture, and that which first brought him into notice as a painter was 'Paolo and Francesca da Rimini,' exhibited at the Salon in 1863."

“. . . Soon as the wind sways them toward us, I lifted my voice:

' $O$ wearied souls, come to speak with us, if Another deny it not.'

As doves, called by desire, with wings open and steady, come through the air borne by their will to their sweet nest, these issued from the troop where Dido is, coming to us through the malign air, so strong was the compassionate cry." -The Divine Comedy, "Hell," v. 81 et seq. 


\title{
DESNOYERS, AUGUSTE GASPARD LOUIS BOUCHFR
}

One of the most eminent of modern French engravers. Born in Paris in 1779. Died there in $185 \%$.

"He appears to the best advantage in his transcripts of the works of the ancient masters, especially Raphael, whose characteristics he renders with the greatest truth and skill."- "Bryan's Dictionary of Painters and Engravers."

2986-LA VIERGE DE LA MAISON D'ALBE

After the painting by Raphael. Fine impression, with the full inscription, on India paper. Oak frame.

\section{FERRIS，STEPHEN J.}

298\%-DREAMLAND

After the painting by C. D. Weldon. Remarque proof, on vellum, signed by both painter and etcher. Oak and bronze frame.

\section{FLAMENG，LÉOPOLD}

\begin{abstract}
"He can overcome any technical difficulty that Rembrandt himself could overcome; and it is not an exaggeration of the truth to affirm that there exists in Europe in our own day a man who may be said to possess the hand and eye of Rembrandt."-P. G. Hamerton, "Etching and Etchers," p. 399.
\end{abstract}

2988-GROLIER AT THE HOUSE OF ALDUS

After the painting by François Flameng, executed for and owned by the Grolier Club. Remarque proof on Japanese paper. Signed by both painter and etcher. There were issued 300 proofs on Japanese paper and three on vellum for members of the Grolier Club only. Gold frame.

\section{HAIG, AXEL HERMAN}

The most popular living etcher of architectural subjects. 2989-A STREET IN SEVILLE, AND THE GIRALDA TOWER

Signed artist's proof, on Whatman paper. Oak and bronze frame. 2990-A CORNER IN SEVILLE

Signed artist's proof, on Whatman paper. Oak and bronze frame. 


\section{JACQUET, JULES}

Pupil of Henriquel-Dupont, Pils and Laemlin. One of the greatest of modern etchers from pictures. His plates after Meissonicr are marvels of technical skill.

2901-“1814"

After the painting by Meissonier. Remarque proof, on vellum.

Signed by both painter and etcher. Oak and bronze frame.

\section{KELLER, JOSEPH}

2992-MADONNA DI SAN SISTO

Andreser, No. 7.

Signed artist's proof, on India paper. Gold frame.

\section{LAI.ANNE，MAXIME}

"No one ever etched so gracefully as Maxime Lalanne. This merit of gracefulness is what chiefly distinguishes him; there have been etchers of greater powers, of more striking originality, but there has never been an etcher equal to him in a certain delicate elegance, from the earliest times till now."-P. G. Hamerton, "Etching and Etchers," p. 177.

2993-SOUVENIR D'UN PORT-TROUVILLE

Remarque proof, signed, on Japanese paper. Gold frame.

\section{LAUWERS, NICOLAES}

Born at Leuze, Tournay. Studied at Antwerp under the celebrated engravers after Rubens, and attached himself particularly to the style of Paulus Pontius, which he imitated with success. His best plates are after the paintings by Rubens. Died at Antwerp in 1652.

2994-CHRIST BEFORE PILATE

After the painting by Rubens. Fine impression, before the name of Boswert was substituted for that of Lauwers. Oak and gold frame. 


\section{LECOUTEUX, LIONEL}

A pupil of Waltner.

2995-THE HARVESTERS

After the painting by J. F. Millet. Signed artist's proof, on vellum. Oak and bronze frame.

\section{LEFORT, HENRI}

Born in Paris, August 31, 1852. Pupil, in painting, of Cabanel; and in etching of Léopold Flameng. For his etching of Washington he was awarded a medal at the Salon of 1881, and in 1890 his large portrait of Léon Gambetta earned for him the decoration of the Legion of Honor. In 1888 Lefort was elected president of the Société des Aquafortistes Français, and has been twice reelected.

\section{6-BENJAMIN FRANKLIN AT THE AGE OF SEVENTY-THREE}

After the painting by Joseph S. Duplessis (1725-1802); presented by Mr. George A. Lucas to the W. H. Huntington Collection of Americana at the Metropolitan Museum of Art, New York. Remarque proof on Japanese paper. Gold frame. There were printed 387 proofs on Japanese paper, and 4 proofs on vellum, for members of the Grolier Club only.

\section{MANDEL, JOHANN AUGUST EDUARD}

Born at Berlin in 1810. Died in 1882. The last of the great lineengravers.

2997-MADONNA DELLA SEDIA

Andresen, No. 18.

After the painting by Raphael, in the Pitti Palace. Second state (of 4) with name and date 1865 very lightly traced, but before all other letters. Superb impression on India paper. Signed artist's proof. Gold frame. 


\section{PONTIUS, PAULUS}

Born at Antwerp, 1603. Instructed in the art of engraving by Lucas Vorsterman, but improved his designs by the advice and friendship of Rubens, from whose works he engraved-many admirable plates. He died in 1658.

"Few artists have equalled him in the correct and faithful delineation of his model; and in the character and expression of his figures he appears to have possessed himself of the mind of Rubens. His plates are executed with the graver in a clear, bold style, and will ever be esteemed among the ablest productions of Flemish art."

2998-CHRIST BEARING THE CROSS

After the painting by Rubens. Fine impression, with large margins. Oak and gold frame.

\section{PROPERT, J. LUMSDEN}

A contemporary English etcher, who has formed his style largely upon that of Seymour Haden.

\section{9-THE SHIPWRECK}

After the painting by J. M. W. Turner. Signed artist's proof. Oak and bronze frame. A most powerful etching, similar in intention to Calais Pier by Seymour Haden; also after Turner.

\section{STACKPOOLE, F.}

\section{0-DESOLATION}

After the painting by Briton-Riviere. Proof on India paper. Signed by both painter and etcher. Gold frame.

\section{TOSCHI, PAOLO}

Born at Parma in 1788, where he became Director of the Academy of Fine Arts, and died in 1858. A pupil of Bervic.

"The last of the great Italian engravers was Paolo Toschi, pupil of Bervic who was himself a pupil of Wille. It remained for Toschi to discover in the lovely frescoes of Correggio, at Parma, a mine of the richest ore, which his predecessors for more than three centuries had scarcely touched."-Frederick Keppel, "The Golden Age of Engraving." 
After Correggio's fresco in the Church San Giovanni Evangelista, at Parma. Engraved in conjunction with G. Fanti. Proof with names of painter and engravers. Signed Paolo Toschi. Gold frame.

\section{2-GROUP OF CHERUBS AND ANGELS}

After Correggio's fresco in the church San Giovanni Evangelista. Engraved in conjunction with A. Dalco. Proof with names of painter and engravers. Signed Paolo Toschi. Gold frame.

\section{WALTNER, CHARLES}

"L'un des grands graveurs français. Et graveur absolument particulière, dont le nom, marquant une étape dans la marche de son art, signifie l'extrême limite de la liberté dans les procédés d'exécution-en réaction, à la fin du XIXe Siècle, contre la perte de toute liberté, infligée depuis cent ans à la gravure par la formule d'école."-Beraldi.

\section{3-THE WAYFARERS}

After the painting by Frederick Walker. Signed artist's proof, on Whatman paper. Bronze frame.

"The suggestion of onward movement . . . is perfect. . . . The landscape with its late autumn melancholy, its moist atmosphere, its maze of tangled branches and twigs nearly stripped of their leaves, is one of the painter's most elaborate and beautiful transcriptions from nature."-Claude Phillips, "Frederick Walker and His Works," p. 22.

\section{4-L'ANGELUS}

After the painting by J. F. Millet. Remarque proof, on vellum. Signed by Waltner. The smaller plate. The remarque is a portrait of Waltner. Oak and bronze frame.

"The etcher has entered quite heartily into the sincere and earnest spirit of the painter, and has etched the picture with so much good taste and feeling that the effect on the heart is quite that of the original painting itself." $-P$. G. Hamerton, "Etching and Etchers," p. 376. 
After the painting by Munkacsy. Proof with the double remarque. Portraits of Munkacsy and of Waltner. Signed by both painter and etcher, on Japanese paper. Oak and bronze frame.

"Waltner has imbued himself with the spirit of the great Hungarian master in popularizing one of the highest works in modern art."

3006-PORTRAIT WOVEN IN SILK

Portrait of J. M. Jacquard, inventor of the Jacquard loom, woven in silk after the painting by C. Bonnefond. Gold frame.

300\%-BABY'S $B A T H$

Engraved by Fred. August Ludy. After the drawing by Ludwig Knaus. Dedication proof, before all letters, on India paper. Gold frame.

\section{AMERICAN ART ASSOCIATION,}

Managers.

THOMAS E. KIRBY,

Auctioneer. 












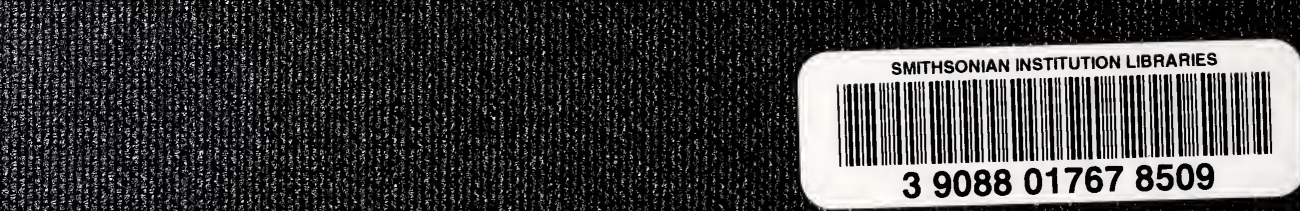

39088017678509

Whathom

the

W.

7.



m

4.6.

3.

Whom

Wח

WW

W

WWWWW

Whym 